\author{
ANA LÚCIA SILVEIRA LESSA
}

\title{
AVALIAÇÃO DOS MECANISMOS BÁSICOS DE ATIVAÇÃO VIA RECEPTORES SEMELHANTES AO TOLL 4 (TLR-4) EM MONÓCITOS DE RECÉM- NASCIDOS A TERMO E PRÉ-TERMO
}

Tese apresentada ao Programa de PósGraduação em Biologia da Relação Patógeno-Hospedeiro do Instituto de Ciências Biomédicas da Universidade de São Paulo, para obtenção do Título de Doutor em Ciências. 


\section{AVALIAÇÃO DOS MECANISMOS BÁSICOS DE ATIVAÇÃO VIA RECEPTORES SEMELHANTES AO TOLL 4 (TLR-4) EM MONÓCITOS DE RECÉM- NASCIDOS A TERMO E PRÉ-TERMO}

Tese apresentada ao Programa de PósGraduação em Biologia da Relação Patógeno-Hospedeiro do Instituto de Ciências Biomédicas da Universidade de São Paulo, para obtenção do Título de Doutor em Ciências.

Área de concentração: Biologia da Relação Patógeno-Hospedeiro

Orientadora: Dra. Patricia Palmeira Versão original 
DADOS DE CATALOGAÇÃO NA PUBLICAÇÃO (CIP)

Serviço de Biblioteca e Informação Biomédica do Instituto de Ciências Biomédicas da Universidade de São Paulo

(C) reprodução total

Lessa, Ana Lúcia Silveira.

Avaliação dos mecanismos básicos de ativação via receptores semelhantes ao Toll 4 (TLR4) em monócitos de recém-nascidos a termo e pré-termo / Ana Lúcia Silveira Lessa. -- São Paulo, 2014.

Orientador: Profa. Dra. Patrícia Palmeira.

Tese (Doutorado) - Universidade de São Paulo. Instituto de Ciências Biomédicas. Departamento de Parasitologia. Área de concentração: Biologia da Relação Patógeno-Hospedeiro. Linha de pesquisa: Desenvolvimento da resposta imune inata do recém-nascido.

Versão do título para o inglês: Evaluation of the basic mechanisms of activation via Toll-like receptor 4 (TLR-4) in monocytes from term and preterm newborns.

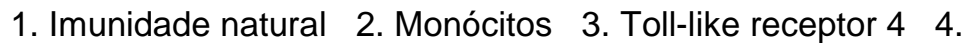
Escherichia coli 5. Recém-nascido prematuro 6. Fagocitose I. Palmeira, Profa. Dra. Patrícia II. Universidade de São Paulo. Instituto de Ciências Biomédicas. Programa de Pós-Graduação em Biologia da Relação Patógeno-Hospedeiro III. Título. 
Candidato(a):

Título da Tese:
Ana Lúcia Silveira Lessa.

Avaliação dos mecanismos básicos de ativação via receptores semelhantes ao Toll 4 (TLR4) em monócitos de recém-nascidos a termo e pré-termo.

Profa. Dra. Patrícia Palmeira.

Orientador(a):

A Comissão Julgadora dos trabalhos de Defesa da Tese de Doutorado, em sessão pública realizada a considerou

( ) Aprovado(a)

( ) Reprovado(a)

\begin{tabular}{|c|c|}
\hline Examinador(a): & $\begin{array}{l}\text { Assinatura: } \\
\text { Nome: ........ } \\
\text { Instituição: }\end{array}$ \\
\hline Examinador(a): & $\begin{array}{l}\text { Assinatura: } \\
\text { Nome: ........ } \\
\text { Instituição: }\end{array}$ \\
\hline Examinador(a): & $\begin{array}{l}\text { Assinatura: } \\
\text { Nome: ........ } \\
\text { Instituição: }\end{array}$ \\
\hline Examinador(a): & $\begin{array}{l}\text { Assinatura: } \\
\text { Nome: ........ } \\
\text { Instituição: }\end{array}$ \\
\hline Presidente: & $\begin{array}{l}\text { Assinatura: } \\
\text { Nome: ........ } \\
\text { Instituição: }\end{array}$ \\
\hline
\end{tabular}




\section{PARECER 929 /CEP}

A Comissão de Ética em Pcsquisas com Sercs Humanos do $1 C B$, nâ sessão de 26.02.2010 AProvou o projeto intitulado: "Avaliação da imunidade inata do recém-nascido a termo e pré-termo: mecanismos básicos de ativação via receptores semelhantes ao Toll 4 (TLR4) em diferentes células apresentadoras de antígenos" sob responsabilidade de execução dos autores Profa. Dra. Patrícia Palmeira e a aluna Ana

\section{Lúcia Silveira Lessa Marques.}

Cabe aos pesquisadores executantes elaborar e apresentar a este Comitê, relatórios anuais (parciais ou final), de acordo com a resolução 196/06 do Conselho Nacional da Saúde, item IX.2 letra c.

O primeiro relatório deverá ser encaminhado à Secretaria deste CEP em 26.02.2011

Atenciosamente,

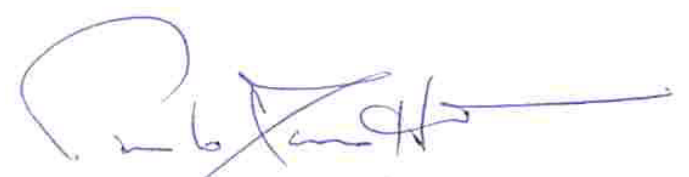

Prof. Dr. PaOlo Marinho AndRade ZanotTo Vice-Coordenador da Comissão de Ética em Pesquisas com Seres Humanos - ICB/USP 
São Paulo, 2 de outubro de 2009.

$I l^{m o(a)} \cdot S^{r(a)}$.

\section{Dra. Patricia Palmeira}

Departamento de Pediatria da Faculdade de Medicina

UNIVERSIDADE DE SÃO PAULO

REFERENTE: Projeto de Pesquisa "Avaliação da imunidade inata do recém-nascido a termo e pré-termo: mecanismos básicos de ativação via receptores semelhantes ao Toll 4 (TLR4) em diferentes células apresentadoras de antígeno" - Coinvestigador(es): Ana Lúcia Silveira Lessa Marques, Dra. Maria Ether Jurfest Rivero Ceccon, Dr. Marco Antônio Cianciarullo, Dra. Magda Carneiro-Sampaio, Gerlândia Neres Pontes, Euler João Kernbichler - Registro CEP-HU/USP: 914/09 - SISNEP CAAE: 0414.0.015.198-09

Prezado(a) Senhor(a)

O Comitê de Ética em Pesquisa do Hospital Universitário da Universidade de São Paulo, em reunião ordinária realizada no dia 2 de outubro de 2009, analisou o Projeto de Pesquisa acima citado, considerando-o como APROVADO, bem como o seu Termo de Consentimento Livre e Esclarecido.

Lembramos que cabe ào pesquisador elaborar e apresentar a este Comitê, relatórios anuais (parciais ou final, em função da duração da pesquisa), de acordo com a Resolução n 196/96 do Conselho Nacional de Saúde, inciso IX.2, letra "c".

O primeiro relatório está previsto para 2 de outubro de 2010.

Atenciosamente,

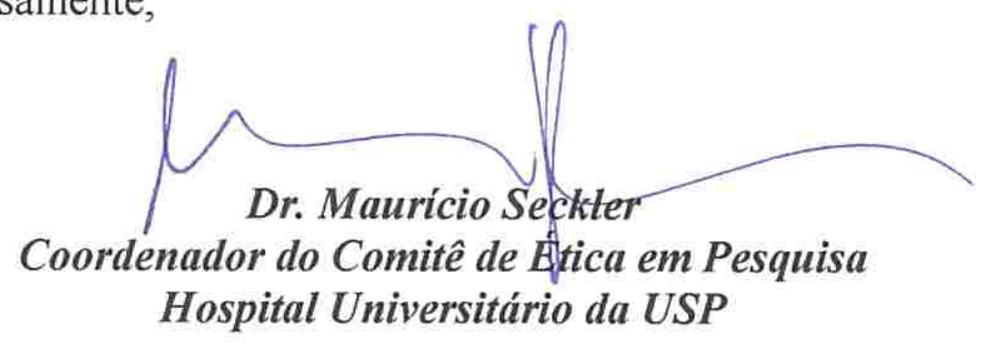




\section{APROVAÇÃO}

A Comissão de Ética para Análise de Projetos de Pesquisa CAPPesq da Diretoria Clínica do Hospital das Clínicas e da Faculdade de Medicina da Universidade de São Paulo, em sessão de 10/03/2010. APROVOU O Protocolo de Pesquisa n 0101/10. intitulado: "AVALIAÇÃO DA RESPOSTA IMUNE NEONATAL: MECANISMOS BÁSICOS DE ATIVAÇĀO VIA RECEPTORES SEMELHANTES AO TOLL 2 E 4 (TLR-2 E 4) EM DIFERENTES CÉLULAS APRESENTADORAS DE ANTÍGENOS DE RECÉM-NASCIDOS A TERMO E PRÉTERMO SAUDÁVEIS E COM SEPSE PRECOCE E TARDIA" apresentado pelo Departamento de PEDIATRIA, inclusive o Termo de Consentimento Livre e Esclarecido.

Cabe ao pesquisador elaborar e apresentar à CAPPesq. os relatórios parciais e final sobre a pesquisa (Resolução do Conselho Nacional de Saúde $n^{\circ} 196$, de 10/10/1996, inciso IX.2, letra " $\mathrm{C}$ ")

Pesquisador (a) Responsável: Dra. Patricia Palmeira

Pesquisador (es) Executante(s): Ana Lúcia Silveira Lessa Marques, Camila Quinello Gomes de Faria, Maria Esther J.R. Ceccon, Gerlândia Neres Pontes, Marco Antonio Cianciarullo, Euler João Kernbichler, Magda M.S. Carneiro Sampaio

Prof. Dr. Eduardo Massad Presidente da Comissão de Ética para Análise de Projetos de Pesquisa

Comissa de Euca para Anatse de Projetos de Pesquisa do HCFMUSP e da FMUSP Diretoria Cunca do Hospitar das Chnicas da Facuidade de Medicina da Universidade de Sáo Paulo Rua Ovidio Pres de Campos, 225, $5^{\circ}$ andar-CEP 05403010 - Sâo Paiso - SP Fone 0113069 $5442 \mathrm{fax} 01130696492$ e-mail cappesq@ncnet usp br / secretarracappesq2@hcnet usp br 
A FORÇA criadora do universo...

.... a minha amada $\mathcal{M} \tilde{A} E$ CÉLIA que deixou a marca mais preciosa que são os valores morais que me fortalecem a cada dia e norteiam minha vida. Você sempre será a MMINFHA MAIOR AMIGA E CONFIDENTTE.

Ao meu amado PAI EDSONPELA VALENTIA ... sempre ao nosso lado e de nossa CÉLIA nos momentos mais importantes.

Às três BONEQUINHHAS da minha vida, FERNANDA, MARIA FERJANDA e ANA LUIZA ... vocês são a "alegria de menina".

AO MEV GRANDE AMOR LVCIANO que é incontestavelmente o SOL das minhas manhãs... TE $\mathcal{A M M O}$

... LUIZ ANTÔSIIO, carinhosamente chamado de POLENTINHFA ... Ainda não sabe ler mas sente o quanto o AMO. 
A VOVÓ LUTE pelo carinho e amoroso cuidado com todos nós.

À MINHA ORIENTADORA Dra. PATRICIA PALMEIRA pela oportunidade de aprender mais...

as lições de COMMPANHEIRISMO, LEALDADE e

HONESTIDADE.

MUITO OBRIGADA! 


\section{AGRADECIMENTOS}

A minha orientadora Patricia Palmeira pelo grande companheirismo, confiança, compreensão, apoio, incentivo e ensinamentos durante todo esse processo desafiador do Doutorado;

À companheira de trabalho Camila Quinello pela parceria nesse nosso desafio do Doutorado, e compreensão durante todo período que passei de inquietude familiar;

Aos amigos do Laboratório de Investigação Médica LIM-36, Laila Lima, Jerusa Arantes, Camila Rennó, Fernanda Andrade Macaferri da Fonseca, Thais Scudelletti Rodrigues, Estela Novack, Victor Figueredo, Ana Carolina Dias Ferreira, Regiane Bovolenta, Ana Caroline de Oliveira;

Às amigas do extinto Laboratório de Imunologia de Mucosas, Elaine Cristina, Cristina Arslanian Kubo, Flávia Lima, Simone Corrêa da Silva, Leuridan Torres, Fabiana Ghilardi, Gerlândia Neres Pontes;

À enfermeira Silvana Andrade pela atenção e coração de mãe que me recebeu no Centro Obstétrico do Hospital das Clinicas;

Ao Dr. Marco Antônio Cianciarullo pela parceria no projeto, disponibilidade e atenção na coleta de dados dos prontuários das parturientes;

Aos colegas os quais auxiliaram e compartilharam momentos do Doutorado, Josias Brito Frazão, Litzy Lina Choquechambi, Rosana Galev Oliveira;

Às professoras Maria Isabel Morais Pinto, Maria Esther J. Rivero Ceccon e Roxane Piazza que contribuíram de forma muito construtiva para o melhor desenvolvimento do nosso trabalho por ocasião do Exame de Qualificação;

À FAPESP (Fundação de Amparo à Pesquisa do Estado de São Paulo) pelo apoio financeiro.

A secretária da pós-graduação do Departamento de Parasitologia Silvia Ferreira Camargo pela presteza e simpatia neste período do Doutorado. 


\section{RESUMO}

Silveira-Lessa AL. Avaliação dos mecanismos básicos de ativação via receptores semelhantes ao Toll 4 (TLR-4) em monócitos de recém-nascidos a termo e pré-termo [Tese (Doutorado em Biologia da Relação PatógenoHospedeiro)]. São Paulo: Instituto de Ciências Biomédicas, Universidade de São Paulo; 2014.

A susceptibilidade do neonato à invasão de patógenos está relacionada, em parte, a imaturidade funcional do sistema imune. Uma ativação eficiente de linfócitos $\mathrm{T}$ neonatais requer a ativação de células apresentadoras de antígenos (APC), a qual envolverá a indução da expressão de moléculas coestimuladoras, assim como a produção de diversas citocinas. Uma das importantes vias de ativação das APC é desencadeada pela estimulação dos diversos receptores semelhantes ao Toll (TLR, do inglês Toll-like receptors) já identificados. O lipopolissacarídeo (LPS) de bactérias Gram-negativas, reconhecido pelo TLR-4, é um dos principais imunoestimuladores presente na membrana celular bacteriana, que induz à ativação de diversas proteínas intracelulares e translocação de diferentes fatores de transcrição essenciais para a expressão dos genes que mediam a resposta inflamatória. Consequentemente, o TLR-4 tem um papel crucial na indução da imunidade inata e adquirida contra bactérias Gram-negativas. Estudos sugerem que a imaturidade do sistema imune adaptativo ao nascimento envolve alterações funcionais das APC. Desta forma, o objetivo consistiu na avaliação da ativação e resposta de monócitos mediante estímulo de TLR-4 com LPS em amostras de sangue de cordão umbilical de recém-nascidos (RN) saudáveis pré-termo $<34$ semanas (Grupo 1), pré-termo entre $\geq 34$ e $<37$ semanas (Grupo 2) e a termo $\geq 37$ semanas (Grupo 3). Foram determinados os niveis de expressão dos marcadores de superficie celular e a produção de citocinas pró- e anti-inflamatórias, além da avaliação da expressão proteica de moléculas envolvidas na sinalização intracelular. A caracterização das populações leucocitárias, a função fagocitária e o burst oxidativo foram analisados por citometria de fluxo. Os resultados mostraram que monócitos neonatais respondem ao estímulo, com níveis altos de produção das citocinas pró-inflamatórias IL-8, TNF- $\alpha$, IL-1 $\beta$ e IL-6. Esses dados mostram que o RN apresenta plena capacidade de desenvolver resposta próinflamatória, intensificada pela significativa menor produção de IL-10, uma importante citocina anti-inflamatória, pelos neonatos quando comparados aos adultos. A técnica de Phosflow foi usada na determinação dos níveis de expressão das proteínas envolvidas na via de sinalização intracelular, como:

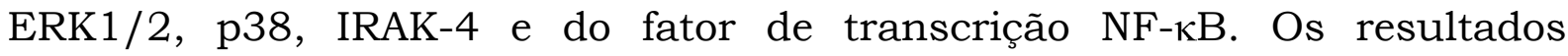
mostraram que o fator de transcrição $\mathrm{NF}-\kappa \mathrm{B}$ apresentou ativação semelhante entre os grupos de neonatos e adultos. As moléculas p38, ERK-1/2 e IRAK-4 apresentaram-se mais ativadas em monócitos dos RN do Grupo 1 quando comparados aos RN do Grupo 3 e adultos. A análise da capacidade fagocitária de monócitos e neutrófilos neonatais desafiados com Escherichia coli mostrou competência fagocitária reduzida quando comparada aos adultos. A produção de $\mathrm{H}_{2} \mathrm{O}_{2}$ após estímulo foi reduzida em monócitos e 
neutrófilos apenas dos RN pré-termo. Os dados apontam uma menor eficiência dos monócitos neonatais, principalmente em prematuros, para fagocitar e eliminar o patógeno, com uma tendência maior a inflamação e um comprovado menor controle da resposta, evidenciado pela menor produção de IL-10. Sendo assim, os resultados sugerem um perfil imunológico neonatal funcionalmente distinto, revelando um desequilibrio da resposta imune inata, com uma menor eficiência no controle desta resposta, o que pode levar a uma predisposição à sepse.

Palavras-chave: Recém-nascido a termo e pré-termo. Monócitos. Receptor Toll-like 4. Imunidade inata. 


\begin{abstract}
Silveira-Lessa AL. Evaluation of the basic mechanisms of activation via Tolllike receptor 4 (TLR-4) in monocytes from term and preterm newborns [Ph. D. thesis (Biology of Host-Pathogen Interactions)]. São Paulo: Instituto de Ciências Biomédicas, Universidade de São Paulo; 2014.
\end{abstract}

The neonatal susceptibility to pathogen invasion is related, in part, to the functional immaturity of its immune system. Efficient activation of neonatal $\mathrm{T}$ cells requires activation of antigen presenting cells (APCs), which involve induction and expression of costimulatory molecules, as well as production of various cytokines. One of the important routes in activation of APCs is triggered by stimulation of several Toll-like receptors (TLR) already identified. The lipopolysaccharide (LPS) of Gram-negative bacteria, recognized by TLR4 , is a major immunostimulatory component present in bacterial cell membrane, which leads to activation of several intracellular proteins and translocation of different transcription factors, essential for the expression of the genes that mediate the inflammatory response. Consequently the TLR-4 plays a crucial role in the induction of innate and acquired immunity against Gram-negative bacteria. Studies suggest that immaturity of the adaptive immune system at birth involves functional alterations of the APCs. Thus, the objective was to assess the activation and response of monocytes by stimulation of TLR-4 with LPS in umbilical cord blood samples from healthy preterm newborns (NBs) $<34$ weeks (Group 1), from preterm NBs $\geq 34$ and $<37$ weeks (Group 2) and term NBs $\geq 37$ weeks (Group 3). We determined the expression levels of cell surface markers and production of pro and antiinflammatory cytokines, in addition to protein expression of the molecules involved in intracellular signaling. The characterization of the leukocyte populations, phagocytic and oxidative burst function were analyzed by flow cytometry. The results showed that neonatal monocytes respond to stimulation with high levels of pro-inflammatory cytokines IL- 8 , TNF- $\alpha$, IL-1 $\beta$ and IL- 6 production. These data show that newborns have full capability of developing a pro-inflammatory response, enhanced by the significantly lower production of IL-10, an important anti-inflammatory cytokine, in newborns compared to adults. The Phosflow technique was used to determine the expression levels of the proteins involved in intracellular signaling pathway, such as ERK1/2, p38, IRAK-4 and the transcription factor NF- $\kappa$. The results demonstrated that the transcription factor $\mathrm{NF}-\kappa \mathrm{B}$ showed similar activation between neonatal and adult groups. The molecules p38, ERK-1/2 and IRAK-4 were more activated in monocytes from newborns of Group 1 compared to Group 3 and adults. The analysis of the phagocytic ability of neonatal monocytes and neutrophils challenged with Escherichia coli showed reduced phagocytic competence when compared to adults. The $\mathrm{H}_{2} \mathrm{O}_{2}$ production after stimulation was reduced in monocytes and neutrophils only from preterm infants. The data show a lower efficiency of neonatal monocytes, especially in preterm infants, to phagocyte and eliminate the pathogen, with a greater tendency to inflammation and a proven lower control of the response, evidenced by the lower production of IL-10. Thus, 
the results suggest a functionally distinct neonatal immunologic profile, revealing an imbalance of the innate immune response, with a lower efficiency in the control of this response, which can lead to a predisposition to sepsis.

Key words: Term and preterm newborn. Monocytes. Innate immunity. Tolllike receptor 4. 


\section{LISTA DE FIGURAS}

Figura 1. Visão esquemática da via de sinalização do receptor

Toll-like 4 (TLR-4)

Figura 2. Concentrações séricas de IL-8, IL-6, IL-17A, IL-1 $\beta$, TNF$\alpha$, IL-10, IL-2, IL-4 e IL-12p70 em amostras de soro de cordão umbilical de RN pré-termo e a termo saudáveis

Figura 3. Concentrações de CD14 solúvel (CD14s) em amostras 68 de soro de cordão umbilical dos RN dos Grupos 1, 2 e 3

Figura 4. Mediana do número absoluto (células/ $\mu$ ) das 71 populações de células dendríticas totais (Lin-HLA-DR+); Frequência (\%) de células dendríticas mieloides CD11c (B) e plasmocitoides CD123 (C); imaturas (CD1a); expressando os marcadores CD80, CD86 e TLR-4 em amostras de sangue de cordão dos RN dos Grupos 1, 2 e 3 e de sangue de adultos

Figura 5. Mediana do número absoluto da população de 73 monócitos $\mathrm{CD}_{14}{ }^{+} \mathrm{HLA}-\mathrm{DR}{ }^{+}$e Mediana da Frequência (\%) dos marcadores de ativação celular CD80 e CD86, e TLR-4 em amostras de sangue de cordão umbilical dos RN dos Grupos 1, 2 e 3 e de sangue periférico de adultos

Figura 6. Mediana do número absoluto da população de linfócitos 75 $\mathrm{T}$ e mediana das frequências das subpopulações de linfócitos T: linfócito T naive; Linfócito T efetor: Linfócito $\mathrm{T}$ memória central; Linfócito $\mathrm{T}$ memória efetora em amostras de sangue de cordão umbilical dos RN dos Grupos 1, 2 e 3 e de sangue periférico de adultos

Figura 7. Mediana do número absoluto dos linfócitos $B$ e 76 mediana da frequência das subpopulações de linfócito B: Linfócito B naive; Linfócito B de memória; Linfócito B ativado; Linfócitos B expressando TLR-4 e CD40 em amostras de sangue de cordão umbilical dos RN dos 
Grupos 1, 2 e 3 e de sangue periférico de adultos

Figura 8. Mediana da intensidade de fluorescência (MFI) da 78 expressão dos marcadores HLADR, CD40, CD80, CD86 e TLR-4 das culturas de monócitos por 18 horas em amostras de sangue de cordão umbilical dos RN dos Grupos 1,2 e 3 e de sangue periférico de adultos

Figura 9. Concentrações das citocinas IL-8, IL-1 $\beta$, IL-6, TNF- $\alpha$ e 80 IL-10 das culturas de monócitos de 18 horas em amostras de sangue de cordão umbilical dos RN dos Grupos 1, 2 e 3 e de sangue periférico de adultos

Figura 10. Marcação de Escherichia coli por microscopia confocal

Figura 11. Dot plots representativos dos gates das populações de neutrófilos e monócitos

Figura 12. Fagocitose de Escherichia coli por monócitos em 83 amostras de sangue de cordão umbilical dos RN dos Grupos 1, 2 e 3 e de sangue periférico de adultos

Figura 13. Fagocitose de Escherichia coli por neutrófilos em amostras de sangue de cordão umbilical dos RN dos Grupos 1, 2 e 3 e de sangue periférico de adultos

Figura 14. Avaliação do burst oxidativo de monócitos em amostras de sangue de cordão umbilical dos RN dos Grupos 1, 2 e 3 e de sangue periférico de adultos

Figura 15. Avaliação do burst oxidativo de neutrófilos em amostras de sangue de cordão umbilical dos RN dos Grupos 1, 2 e 3 e de sangue periférico de adultos

Figura 16. Análise da média da intensidade de fluorescência (MFI) da expressão das proteínas NF-kB, ERK-1/2, p38 e IRAK-4 ativadas (fosforiladas) em cultura de monócitos CD14+HLA-DR+ dos RN dos Grupos 1, 2 e 3 e de adultos não ativados (-) e ativados com LPS O55 


\section{LISTA DE TABELAS}

Tabela 1. Marcadores de superficie celular de células 47 dendríticas mieloides e plasmocitoides

Tabela 2. Marcadores de superficie celular de monócitos

Tabela 3. Marcadores de superficie celular das subpopulações de linfócitos T naive, linfócitos T de memória central e linfócitos T de memória efetora

Tabela 4. Marcadores de superficie celular da subpopulação de linfócitos T efetores

Tabela 5. Marcadores de superficie celular das subpopulações de linfócitos $B$ naive, linfócitos $B$ ativados e linfócitos B de memória

Tabela 6. Marcadores de superficie celular dos monócitos 50 cultivados

Tabela 7. Marcadores das moléculas intracelulares presentes na cascata de ativação celular da via do TLR-4

Tabela 8. Análise de prontuário das parturientes e seus 57 respectivos RN pré-termo pertencentes ao Grupo 1

Tabela 9. Análise de prontuário das parturientes e seus respectivos RN pré-termo pertencentes ao Grupo 2

Tabela 10. Análise de prontuário das parturientes e seus 58 respectivos RN a termo pertencentes ao Grupo 3

Tabela 11. Dados do prontuário das parturientes e seus 60 respectivos RN pré-termo

Tabela 12. Dados do prontuário das parturientes e seus 62 respectivos $\mathrm{RN}$ a termo 
Tabela 13. Dosagem de citocinas nas amostras de soro de RN pré-termo do Grupo 1

Tabela 14. Dosagem de citocinas nas amostras de soro de RN pré-termo do Grupo 2

Tabela 15. Dosagem de citocinas nas amostras de soro de RN a termo do Grupo 3

Tabela 16. Médias dos pesos e das idades gestacionais dos 68 Grupos de RN

Tabela 17. Números de leucócitos totais nas amostras de sangue de cordão umbilical de $\mathrm{RN}$ dos Grupos 1, 2 e 3 e no sangue periférico dos adultos 


\section{LISTA DE ABREVIATURAS E SIGLAS}

APC

AP-1

CBA

CBMC

CDC

CD

CD14s

cMaf

CMV

CREB

CSF

CXCL

DC

DHR

DUM

E. coli

EDTA

ERK

FSC

G

GBS

HIV

HMC

IFN

Ig

IKK

IL
“Antigen presenting cell” (Célula apresentadora de antígeno)

"Transcription factor activator protein 1" (Fator de transcrição proteína de ativação-1)

"Cytometric Bead Array System"

"Umbilical cord blood mononuclear cell" (Célula mononuclear de sangue de cordão umbilical)

"Centers of Disease Control and Prevention" (Centro de Controle e Prevenção de Doenças)

"Cluster of Differentiation" (Grupamento de diferenciação)

CD14 solúvel

Fator de transcrição proto-oncogene cMaf

Citomegalovirus

"Transcription factor cyclic AMP response element-binding protein"

"Colony-stimulating factor" (Fator estimulador de colônias)

"C-X-C motif chemokine" (Quimiocina com motivo $\mathrm{C}-\mathrm{X}-\mathrm{C}$ )

"Dendritic cell" (Célula dendrítica)

Dihydrorhodamine-123

Data da última menstruação

Escherichia coli

Ácido etilenodiaminotetracético

"Extracellular signal-regulated kinases" (Quinase ativada por receptor extracelular)

"Forward scatter" (tamanho)

Gemelar

"Group B Streptococcus" (Estreptococo do grupo B)

"Human immunodeficiency vírus" (Vírus da imunodeficiência humana)

Hemocultura

Interferon

Imunoglobulina

"I kappa B kinase" (I kappa B quinase)

Interleucina 


\begin{tabular}{|c|c|}
\hline IRAK & "IL-1R-associated Kinase" (Quinase associada a IL-1R) \\
\hline IRF & "IFN regulatory factor" (Fator regulador de IFN) \\
\hline ITU & Infecção do trato urinário \\
\hline JNK & “JUN N-terminal Kinase” (Quinase N-terminal c-Jun) \\
\hline LBP & $\begin{array}{l}\text { "Lipopolysaccharide-binding protein" (Proteína ligante de } \\
\text { lipopolissacarídeo) }\end{array}$ \\
\hline LPS & "Lipopolysacchacaride" (Lipopolissacarídeo) \\
\hline LRR & "Leucine-rich repeats" (Motivos repetidos ricos em leucina) \\
\hline LTA & "Lipoteichoic acid” (Ácido lipoteicoico) \\
\hline MAC & "Membrane attack complex" (Complexo de ataque à membrana) \\
\hline MAL & "MyD88 adapter-like" (Adaptador semelhante a MyD88) \\
\hline MAPK & $\begin{array}{l}\text { "Mitogen-activated protein kinase" (Proteína quinase ativada } \\
\text { por mitógeno) }\end{array}$ \\
\hline MBL & Lectina ligante de manose \\
\hline $\mathbf{m D C}$ & "Myeloid dendritic cells" (Células dendríticas mieloides) \\
\hline MD2 & $\begin{array}{l}\text { "Myeloid differentiation protein 2" (Proteína mieloide de } \\
\text { diferenciação 2) }\end{array}$ \\
\hline MEK & "Serine/threonine kinase" (Quinase serina/treonina) \\
\hline MFI & $\begin{array}{l}\text { "Mean fluorescence intensity" (Média de intensidade de } \\
\text { fluorescência) }\end{array}$ \\
\hline $\mathbf{M}_{\mathrm{d}} \mathbf{F I}$ & $\begin{array}{l}\text { "Median fluorescence intensity" (Mediana de intensidade de } \\
\text { fluorescência) }\end{array}$ \\
\hline MHC & $\begin{array}{l}\text { "Major histocompatibility complex" (Complexo principal de } \\
\text { histocompatibilidade) }\end{array}$ \\
\hline MIF & $\begin{array}{l}\text { "Macrophage emigration inhibitory factor" (Fator inibidor de } \\
\text { migração de macrófagos) }\end{array}$ \\
\hline miRNA & MicroRNA \\
\hline mRNA & "Messenger RNA" (RNA mensageiro) \\
\hline MYD88 & $\begin{array}{l}\text { "Myeloid differentiation primary response gene 88" (fator de } \\
\text { diferenciação mieloide 88) }\end{array}$ \\
\hline $\mathbf{N}$ & Número amostral \\
\hline NCHS & $\begin{array}{l}\text { "National Center for Health Statistics" (Centro Nacional para } \\
\text { Estatísticas de Saúde dos Estados Unidos) }\end{array}$ \\
\hline ND & Não detectado \\
\hline NEMO & $\begin{array}{l}\text { "NF-kappa B essential modulator" (Modulador essencial NF- } \\
\text { kappa B) }\end{array}$ \\
\hline NET & $\begin{array}{l}\text { "Neutrophil extracellular traps" (armadilhas extracelulares } \\
\text { neutrófilos) }\end{array}$ \\
\hline
\end{tabular}




\begin{tabular}{|c|c|}
\hline $\mathbf{N F}-\kappa \mathbf{B}$ & “Nuclear factor kappa B” (Fator nuclear Kappa B) \\
\hline NFAT & $\begin{array}{l}\text { "Nuclear factor of activated T-cells" (Fator nuclear de células T } \\
\text { ativadas) }\end{array}$ \\
\hline NF-Y & $\begin{array}{l}\text { "Transcription factor NF-Y (nuclear factor Y)" (Fator de } \\
\text { transcrição NF-Y) }\end{array}$ \\
\hline NICHD & $\begin{array}{l}\text { "National Institute of Child Health and Human Development" } \\
\text { (Instituto Nacional de Saúde Infantil e Desenvolvimento } \\
\text { Humano) }\end{array}$ \\
\hline NK & "Natural killer" (Células exterminadoras naturais) \\
\hline NOD & $\begin{array}{l}\text { "NOD-like receptors" (Receptor semelhante ao domínio de } \\
\text { oligomerização e ligação de nucleotídeo) }\end{array}$ \\
\hline $\mathbf{N R}$ & Não realizada \\
\hline PA & Pronto-atendimento \\
\hline PAMP & $\begin{array}{l}\text { "Pathogen-associated molecular pattern" (Padrão molecular } \\
\text { associado aos patógenos) }\end{array}$ \\
\hline PBMC & $\begin{array}{l}\text { "Peripheral blood mononuclear cell" (Célula mononuclear de } \\
\text { sangue periférico) }\end{array}$ \\
\hline PBS & "Phosphate buffered saline" (Tampão fosfato-salina) \\
\hline $\mathbf{P b x} \mathbf{1 b}$ & "pre-B cell leukemia transcription factor- $1 b$ " \\
\hline PCR & Proteina C-reativa \\
\hline pDC & $\begin{array}{l}\text { "Plasmacytoid dendritic cell" } \\
\text { plasmocitoide) }\end{array}$ \\
\hline PGE2 & Prostraglandina E2 \\
\hline p38 & $\begin{array}{l}\text { "p38 mitogen-activated protein kinase" (Proteína quinase } \\
\text { ativada por mitógeno p38) }\end{array}$ \\
\hline PMA & Phorbol 12-myristate 13-acetate \\
\hline PMN & Polimorfonucleares \\
\hline PRR & $\begin{array}{l}\text { "Pattern recognition receptor" (Receptor de reconhecimento de } \\
\text { padrões) }\end{array}$ \\
\hline PT & Pré-termo \\
\hline RANTES & $\begin{array}{l}\text { "Regulated upon activation, normal T-cell expressed and } \\
\text { secreted" }\end{array}$ \\
\hline RIG1 & $\begin{array}{l}\text { "Retinoic acid inducible gene } 1 \text { " (Ácido retinóico induzivel pelo } \\
\text { gene 1) }\end{array}$ \\
\hline RIP & $\begin{array}{l}\text { "Receptor-interacting protein" (Proteína de interação com o } \\
\text { receptor) }\end{array}$ \\
\hline RLR & $\begin{array}{l}\text { "Retinoic acid-inducible gene-like receptor" } \\
\text { semelhante ao gene induzido pelo ácido retinóico) }\end{array}$ \\
\hline $\mathbf{R N}$ & Recém-nascido \\
\hline
\end{tabular}




\begin{tabular}{|c|c|}
\hline RPM & Rotações por minuto \\
\hline ROS & "Reactive oxygen species" (espécies reativas de oxigênio) \\
\hline RPMI & Meio "Roswell Park Memorial Institute" \\
\hline $\mathbf{R}-10$ & $\begin{array}{l}\text { Meio "Roswell Park Memorial Institute" acrescido de } 10 \% \text { de } \\
\text { soro fetal bovino e } 0,1 \% \text { de azida sódica }\end{array}$ \\
\hline SARM & $\begin{array}{l}\text { "Sterile } \alpha^{-} \text {and armadillo-motif-containing protein" (Proteina } \\
\text { contendo motivo Armadillo e estéril-alfa) }\end{array}$ \\
\hline SFB & Soro fetal bovino \\
\hline Sp & "Sp transcription factor" (Fator de transcrição $\mathrm{Sp}$ ) \\
\hline SSC & "Side scatter" (Granulosidade) \\
\hline $\mathbf{T}$ & Termo \\
\hline TAB & "TAK Binding Protein" (Proteína ligante de TAK) \\
\hline TBK & "TANK-binding kinase" (Quinase ligante de TANK) \\
\hline TGF & $\begin{array}{l}\text { "Transforming growth factor" (Fator de transformação de } \\
\text { crescimento) }\end{array}$ \\
\hline TH & "T helper type" (Célula T auxiliar) \\
\hline TIR & $\begin{array}{l}\text { "Toll/IL-1-receptor homologous region" (Domínio intracelular } \\
\text { com região homóloga a do receptor de IL-1) }\end{array}$ \\
\hline TIRAP & $\begin{array}{l}\text { "TIR-domain-containing adaptor protein" (Molécula adaptadora } \\
\text { contendo o domínio TIR) }\end{array}$ \\
\hline TLR & “Toll like receptor" (Receptor semelhante ao Toll) \\
\hline TNF & "Tumor necrosis factor" (Fator de necrose tumoral) \\
\hline sTNF & $\begin{array}{l}\text { "Soluble tumor necrosis factor receptor" (Receptor solúvel de } \\
\text { TNF) }\end{array}$ \\
\hline TRAF-6 & $\begin{array}{l}\text { "Tumour-necrosis-factor-receptor-associated factor-6" (Fator } 6 \\
\text { associado ao receptor de TNF) }\end{array}$ \\
\hline TRAM & $\begin{array}{l}\text { "TRIF-related adaptor molecule" (Molécula adaptadora } \\
\text { relacionada ao TRIF) }\end{array}$ \\
\hline TRIF & $\begin{array}{l}\text { "TIR-domain-containing adapter-inducing interferon- } \beta \text { " } \\
\text { (Adaptador contendo dominio TIR indutor de IFN- } \beta \text { ) }\end{array}$ \\
\hline & Unidade de Tratamento Intensivo \\
\hline
\end{tabular}




\section{SUMÁRIO}

1.1 Imunidade Neonatal e particularidades da 30 Prematuridade

1.2 Receptores do tipo Toll (TLR)

$1.3 \quad$ Monócitos Neonatais

$1.4 \quad$ Justificativa

OBJETIVO

$2.1 \quad$ Objetivo geral

2.2 Objetivos especificos

3.1 Casuística

3.2 Agonista do TLR-4 45

3.3 Métodos 45

3.3.1 Dosagem de citocinas e CD14 solúvel em soro de 45 cordão umbilical

3.3.2 Imunofenotipagem de leucócitos do sangue de 46 cordão umbical

3.3.3 Estudo funcional da população de monócitos 49

3.3.3.1 Obtenção de células mononucleares de sangue de 49 cordão umbilical

3.3.3.2 Cultura de monócitos

3.3.3.3 Dosagem de citocinas em sobrenadante de cultura de 51 monócitos de sangue de cordão umbilical

3.3.4 Análise da função fagocitica e burst oxidativo por 51 DHR (Dihidrorodamina 123)

3.3.5 Quantificação da expressão das moléculas 52 fosforiladas por citometria de fluxo 
3.4 Análise Estatística 53

$4 \quad$ RESULTADOS 56

4.1 Grupo Amostral 56

4.2 Dosagem de citocinas e CD14s nas amostras de soro 63 de cordão umbilical

4.3 Imunofenotipagem de leucócitos do sangue de 69 cordão umbilical

4.4 Estudo funcional dos monócitos 77

4.5 Análise da função fagocitica e burst oxidativo pelo 81 método de DHR

4.6 Análise das moléculas da via de sinalização 87 intracelular de TLR-4 em monócitos por citometria de fluxo

5

$\begin{array}{ll}\text { DISCUSSÃO } & 90\end{array}$

6

CONCLUSÃo 116

REFERÊNCIAS $\quad 118$

APÊNDICE A - Ficha de anamnese das parturientes 134

APÊNDICE B - Termo de consentimento livre e 139 esclarecido

APÊNDICE C - Phenotypic Differences in Leucocyte 143 Populations among Healthy Preterm and Full-Term Newborns

APÊNDICE D - TLR-2 and TLR-4 expression in 158 monocytes of newborns with late-onset sepsis 
1 INTRODUÇÃO 
O nascimento prematuro é definido como o nascimento antes de 37 semanas completas de gestação, o qual pode ser iniciado por inúmeros fatores, dentre eles, a exposição a desencadeadores ambientais, estresse materno, anormalidades genéticas fetais ou maternas e desequilibrio hormonal.

O nascimento prematuro ocorre em $11 \%$ dos nascidos vivos no mundo, sendo responsável por 35\% das mortes neonatais (Blencowe et al., 2012; Howson et al., 2012).

As taxas de nascimento prematuro vêm aumentando em todo o mundo, principalmente à custa de recém-nascidos (RN) prematuros tardios, os quais foram assim denominados recentemente, em 2005, em um seminário organizado pelo Instituto Nacional de Saúde Infantil e Desenvolvimento Humano (NICHD), no qual foram definidas a terminologia, epidemiologia, etiologia, biologia da maturação, cuidados clínicos, sobrevivência e aspectos de saúde pública dos RN pré-termo tardio. Foi estabelecido que o recém-nascido pré-termo tardio é aquele que nasce com 34 semanas de gestação completas até 36 semanas e 6 dias, contadas após o primeiro dia do último período menstrual. Já o recém-nascido pré-termo moderado é aquele nascido com 32 semanas de gestação completas até 33 semanas e 6 dias, contadas após o primeiro dia do último período menstrual (Guasch et al., 2009; Raju et al., 2006; Ryan et al., 2010).

Mais de 300 trabalhos foram publicados desde 2006 abordando o tema prematuro tardio, que incluem estudos de observação e de intervenção, revisões sistemáticas, editoriais e comitê de opiniões devido à grande importância deste grupo de RN (Martin et al., 2010).

Segundo o Centro de Controle e Prevenção de Doenças (CDC) e o Centro Nacional para Estatísticas de Saúde dos Estados Unidos (NCHS), o aumento na taxa de partos prematuros únicos desde 1990 tem sido quase inteiramente devido ao RN pré-termo tardio. Durante o período de 1990 a 2006, a taxa de nascimento de prematuros tardio em relação aos partos únicos aumentou 20,9\%, passando de 6,7\% para 8,1\%. Esta taxa diminuiu ligeiramente em 2007 e 2008 para 8,0\% e 7,8\%, respectivamente (Hamilton et al., 2010). 
$\mathrm{Na}$ prática clínica, os RN pré-termo tardio têm sido historicamente incluídos como RN a termo devido ao seu tamanho relativamente grande e aparência madura. No entanto, um crescente corpo de evidências sugere que a incidência de problemas de saúde, tanto em curto, como em longo prazo, é maior entre os prematuros tardios do que os nascidos a termo (Escobar et al., 2006; Raju et al., 2006; Ramachandrappa, Jain, 2009; ShapiroMendoza et al., 2008; Wang et al., 2004).

O estudo desenvolvido por Shapiro-Mendoza et al. (2008) descreve um risco 7 vezes maior de desenvolvimento de morbidades neonatais em prematuros tardios, em relação aos nascidos a termo. Já a incidência de eventos potencialmente fatais aparentes em prematuros tardios foi, pelo menos, 8 vezes maior do que em crianças nascidas a termo (Hunt, 2006). Os dados disponíveis sugerem eventos como: sindrome do desconforto respiratório, hipertensão pulmonar persistente, hiperbilirrubinemia, hemorragia intraventricular, sepse comprovada por cultura, instabilidade da temperatura, hipoglicemia, desidratação e dificuldades de alimentação, os quais ocorreram mais frequentemente em RN prematuros tardios do que em RN a termo (McIntire, Leveno, 2008; Ryan et al., 2010; Shaw, 2008). Dados recentes sugerem que os RN pré-termo tardio e moderado também têm maiores riscos de morbidade na infância e deficiência, incluindo paralisia cerebral, baixo rendimento escolar, necessidades educacionais especiais e asma (Abe et al., 2007; Lisonkova et al., 2011).

Apesar da taxa de mortalidade infantil ter diminuído substancialmente nas últimas décadas, a taxa de mortalidade neonatal, especialmente na primeira semana de vida, mudou pouco. Segundo a Organização Mundial de Saúde, no mundo, no ano de 2012, a mortalidade neonatal (primeiros 28 dias de vida completos) foi de 21 em cada 1000 nascidos vivos, sendo que no Brasil foram 9 em cada 1000 nascidos vivos (WHO, 2012).

É preocupante o aumento observado na morbidade neonatal, o que se reflete no aumento da mortalidade. Em estudo de coorte realizado por Tomashek et al. (2007), na população canadense, foi mostrado um risco de morte neonatal e infantil significativamente aumentado em RN prematuros moderados e tardios. Esses autores demonstram que a mortalidade neonatal 
precoce e tardia foi, respectivamente, seis e três vezes maior do que em RN a termo, e a mortalidade infantil foi três vezes maior do que a de crianças nascidas a termo. Embora um número significativo de mortes prematuras em ambos os grupos tenha sido relacionado a anomalias congênitas, as diferenças persistiram após a exclusão dessas crianças.

A infecção é a principal causa de mortalidade entre as crianças nos primeiros dias de vida. Ao nascer, o neonato se move de um ambiente protetor geralmente dito estéril e passa a ser exposto a uma grande variedade de antígenos estranhos, os quais vão desafiar o seu sistema imunológico. Sintomaticamente, a infecção nos RN pode variar desde uma apresentação muito sutil e progredir gradualmente, para uma rápida deterioração e um colapso repentino.

A maioria das mortes neonatais relacionadas com infecção ocorre devido à sepse bacteriana, meningite, infecção respiratória, tétano neonatal, diarréia e onfalite. Estas mesmas infecções podem ocorrer no início do período neonatal, nos primeiros sete dias de vida e são, na maioria dos casos, atribuídas a infecções adquiridas durante o processo de periparto. Já as mortes neonatais tardias (8 a 28 dias de vida) são mais comuns devido à aquisição de patógenos no ambiente em que o RN é exposto (Remington et al., 2011).

A infecção pode se manifestar localizadamente, por exemplo, como pústulas, abscessos, pneumonias, infecções do trato urinário ou meningites. Porém, muitas vezes, os RN apresentam sinais sistêmicos, como apneias recorrentes, hipotenção arterial, choque, insuficiência renal e disfunção hepática, coagulopatia, trombocitopenia, desajuste dos niveis de glicose e também convulsões. A fonte da infecção muitas vezes é dificil de ser identificada, sendo o julgamento clínico importante no diagnóstico e tratamento da sepse neonatal.

As infecções continuam sendo ainda o grande problema de saúde pública entre os $\mathrm{RN}$ e crianças, incluindo a sepse bacteriana, com mortalidade anual global de mais de um milhão de vidas (Lawn et al., 2005; Sanchez-Schmitz et al., 2011; Wynn et al., 2010). Em 2010 foram estimadas 
1,1 milhão de mortes de RN com complicações em parto prematuro, muitas delas ocasionadas por sepse (Lui et al., 2012).

Até mesmo as morbidades menos graves que acometem o prematuro moderado e tardio são reconhecidas como potencial indicador de infecção neonatal sistêmica, sendo assim, não é surpreendente que estes RN sejam investigados com mais frequência por suspeita de sepse do que os RN a termo (Wang et al., 2004).

Em estudo realizado por Cohen-Wolkowiez et al. (2009), 69\% dos bebês prematuros tardios foram selecionados com infecção de início precoce, embora apenas $0,4 \%$ tiveram hemocultura positiva. No entanto, há também evidências que sugerem que esses RN podem ser inerentemente suscetiveis à infecção devido à imaturidade imunológica. Khashu et al. (2009) constataram que as suspeitas ou infecções comprovadas foram cinco vezes mais frequentes em RN pré-termo tardio, enquanto McIntire e Leveno (2008) relataram significativamente mais avaliações de sepse e sepse comprovada por cultura em prematuros tardios, quando comparados aos $\mathrm{RN}$ a termo.

A sepse é uma infecção sistêmica e constitui uma das causas mais frequentes de morbidade em partos prematuros, podendo ocorrer na primeira semana de vida, sendo classificada como de "início precoce", e após a primeira semana até o final do período neonatal (até 28 dias de vida) sendo considerada como de "aparecimento tardio". A sepse de início precoce é convencionalmente considerada maternalmente adquirida, com organismos causadores, tais como Escherichia coli e Streptococcus do Grupo B (GBS), normalmente encontrados no trato genital materno, ao passo que a sepse de início tardio é considerada de origem ambiental ou hospitalar ou, ainda, adquirida na comunidade (Klein, 2001).

Em poucos trabalhos, como o de Zaidi et al. (2005) de âmbito mundial, foram mostrados dados dos países em desenvolvimento relacionando os principais agentes etiológicos de infecções neonatais. Neste estudo com 11.471 amostras de sangue, as bactérias Gram-negativas foram isoladas em, pelo menos, 60\% das hemoculturas positivas. Os autores descrevem um percentual de incidência das espécies de bactérias Gram-negativas Klebsiella, Escherichia coli e Pseudomonas de, respectivamente, 22,8\%, 
$12,2 \%$ e 7,9\% dentro do total de 60,5\% das bactérias Gram-negativas responsáveis pelas infecções neonatais graves. As taxas de casos fatais variam entre $12 \%$ e $52 \%$, com taxas igualmente altas de sepse relacionadas a linhagens de bactérias Gram-negativas. Alguns anos depois, Zaidi et al. (2009) mostram novos dados das populações de RN e agora incluindo a população de jovens lactentes (até 90 dias de vida) em países em desenvolvimento, apresentando relatórios da etiologia das infecções adquiridas na comunidade (sepse, pneumonia, meningite) publicadas desde 1980. Este estudo foi fundamentalmente de base hospitalar com relatos de sepse de início precoce, sepse entre RN internados ou nascidos em casa. Os resultados mostraram na primeira semana de vida (3209 isolados), como principais patógenos: Klebsiella (25\%), Escherichia coli (15\%), e Staphylococcus aureus (18\%). O Streptococcus do Grupo B (GBS) foi relativamente raro $(7 \%)$, embora as diferenças regionais existissem. Depois da primeira semana de vida (835 isolados), S. aureus (14\%), GBS (12\%), Streptococcus pneumoniae (12\%) e espécies de Salmonella não tifoide (13\%) eram mais frequentes. S. pneumoniae (27\%) foi mais comum no período pósneonatal (entre 141 isolados). Os patógenos Gram-negativos predominaram (77\%) entre os neonatos nascidos em casa (entre 170 isolados).

Segundo Strunk et al. (2011), o aumento do risco de infecção bacteriana em RN prematuros deve-se a uma série de determinantes: primeiro, os prematuros extremos requerem cuidados intensivos prolongados, incluindo ventilação mecânica, alimentação parenteral e acesso intravenoso, que violam as barreiras físicas e facilitam a invasão por patógenos hospitalares (Stoll et al., 2002). Em segundo lugar, os neonatos são rapidamente colonizados por microrganismos no ambiente da Unidade de Tratamento Intensivo (UTI) e a susceptibilidade inerente do neonato prematuro torna os micróbios normalmente inócuos em potencialmente patogênicos (Keyworth et al., 1992). Em terceiro, muitos elementos funcionais do sistema imunológico adquirido não funcionam adequadamente no RN, onde a idade gestacional e pós-natal são as determinantes na função imunitária (Adkins et al., 2004). Nestas circunstâncias, os neonatos 
dependem, principalmente, do sistema imunológico inato para a proteção contra infecções invasivas.

\subsection{Imunidade Neonatal e particularidades da prematuridade}

Segundo Melville e Moss (2013), o maior risco dos RN prematuros adquirirem infecções, contribui significativamente para a mortalidade deste grupo. Em virtude da deficiência de proteinas e peptídeos solúveis e de uma resposta celular adequada, a capacidade de responder às infecções fica reduzida. Estes peptídeos e proteínas solúveis possuem capacidade de opsonizar os patógenos ou atuar em sua morte direta, por meio de suas propriedades antimicrobianas. Dentre os fatores inatos humorais, a proteína C-reativa (PCR) e a lectina ligante de manose (MBL) são proteínas solúveis que podem se ligar a estruturas na superficie dos patógenos ou de células do hospedeiro danificadas ou infectadas e facilitar sua remoção por fagócitos. Outros fatores de grande importância que estão correlacionados positivamente com a idade gestacional são as proteínas antimicrobianas, como a lactoferrina e as defensinas, as quais são liberadas pelos leucócitos, incluindo neutrófilos, monócitos/macrófagos e linfócitos, podendo se ligar ao microrganismo e destruí-lo (Levy et al., 2004).

Dentre os fatores solúveis, os $\mathrm{RN}$ apresentam produção própria limitada de imunoglobulinas (Ig) e contam com a transferência de IgG materna, a qual atravessa a placenta em grandes quantidades, principalmente após trinta e duas semanas de gestação. As concentrações de IgG aumentam com a idade gestacional, sendo assim, o RN prematuro possui baixos niveis de IgG materna circulante, levando a uma opsonização deficiente, o que ocasiona uma deficiência na fagocitose (Heininger et al., 2009; Källman et al.,1998; Palmeira et al., 2012; van den Berg et al., 2011).

O complemento representa um sistema efetor crucial da imunidade inata no qual três vias, a clássica, a alternativa e a das lectinas convergem para um ponto onde importantes moléculas efetoras são geradas, como as opsoninas $\mathrm{C} 3 \mathrm{~b}, \mathrm{iC} 3 \mathrm{~b}$ e $\mathrm{C} 4 \mathrm{~b}$, a anafilotoxina C5a e o complexo de ataque à membrana (MAC) C5-C9. As diversas proteínas - efetoras e reguladoras - 
que compõem este sistema não cruzam a placenta e, portanto, as concentrações detectadas no sangue do cordão são sintetizadas pelos hepatócitos e, algumas, por macrófagos do próprio feto (McGreal et al., 2012). Comparado com sangue de adultos saudáveis, o RN apresenta níveis baixos dos vários componentes deste sistema, principalmente da via alternativa, que alcançam, em média, metade dos níveis de adulto, exceto o componente C9, que se encontra em valores que não ultrapassam $20 \%$ dos níveis de adultos. Uma grande variação interindividual é observada e, em muitos neonatos a termo, as concentrações dos componentes ou a atividade total da via alternativa e clássica do complemento (AP50 e CH50, respectivamente) estão dentro dos intervalos normais de adultos. Já neonatos pré-termo mostram uma redução mais acentuada e consistente dos componentes e das atividades da via clássica e alternativa. As baixas concentrações de complemento no começo da vida, particularmente no período neonatal, contribuem para a maior susceptibilidade a algumas bactérias extracelulares, seja pela redução da atividade opsonizante do soro, seja pela deficiência de atividade litica, importante para a destruição de alguns Gram-negativos (Driscoll et al., 1990; Källman et al., 1998; Sharma et al., 2012; Strunk et al., 2011; Swierzko et al., 2009).

Ao nascimento, os neutrófilos apresentam deficiências quantitativas e qualitativas importantes. Os RN a termo e, particularmente, os pré-termo, dispõem de poucas células progenitoras de neutrófilos e assim têm uma limitação de precursores na medula óssea, o que pode resultar em grave deficiência para mobilizar números adequados de neutrófilos por ocasião de uma infecção. Os neutrófilos neonatais também apresentam múltiplos defeitos funcionais, incluindo quimiotaxia, adesão e migração. Foi relatado que neutrófilos de RN pré-termos mostraram uma baixa expressão moléculas de adesão, como L-selectina e E-selectina, importantes no rolamento dos neutrófilos até o foco inflamatório (Nussbaum, Sperandio, 2011).

Os monócitos e neutrófilos são cruciais na primeira linha de defesa, produzindo espécies reativas de nitrogênio e oxigênio (ROS), liberando citocinas, quimiocinas e radicais livres, estimulando o sistema imunológico e 
estabelecendo um estado pró-inflamatório, amplificando e direcionando a resposta imune (Hoebe et al., 2004; Paino et al., 2005). Estas particularidades demonstram a importância que estas células exercem no combate aos patógenos, envolvendo a ingestão, geração de radicais de oxigênio e morte microbiana (Carr, 2000).

\subsection{Receptores do tipo Toll (TLR)}

As imunidades inata e adaptativa são essenciais no combate ao constante desafio da invasão de patógenos virais, bacterianos, parasitários e fúngicos. Na fase inicial de infecção, o sistema imune inato gera uma rápida resposta imune inflamatória que bloqueia o crescimento e a disseminação do agente infeccioso. Esta resposta é acompanhada de uma resposta imune adaptativa buscando a eliminação do patógeno. Os receptores que participam da imunidade adaptativa são altamente específicos para o agente patogênico, no entanto a resposta imune inata utiliza receptores que identificam padrões moleculares associados aos patógenos (PAMPs) (Janeway, Medzhitov, 2002; Medzhitov, Janeway, 2000).

Existe uma variedade de receptores de reconhecimento de padrões (PRRs) que identificam os PAMPs. Estes receptores reconhecem patógenos ou produtos derivados de patógenos em diferentes compartimentos celulares, como a membrana plasmática, endossomo ou citoplasma, induzindo a expressão de citocinas, quimiocinas e moléculas coestimuladoras com o objetivo de eliminar o patógeno e induzir uma resposta imune adaptativa específica. Dentre esses grupos de receptores estão: i. a família de proteínas denominada NOD-like receptors (domínio de oligomerização e ligação de nucleotídeo), que reconhecem produtos bacterianos e virais no citosol; ii. receptores do tipo lectina $\mathrm{C}(\mathrm{LCR})$, como as dectinas 1 e 2, que reconhecem carboidratos em microrganismos, tais como vírus, bactérias e fungos. iii. o ácido retinóico induzível pelo gene I - retinoic acid inducible gene - I (RIG-1)like receptor (RLR), que reconhece diferentes classes de RNA virais e; iv. os receptores semelhantes ao Toll - Toll-Like Receptors (TLR), que reconhecem uma gama de produtos microbianos na superficie celular e em 
compartimentos intracelulares de vários tipos de células como os linfócitos B, células NK (natural killer), células dendríticas (DC), macrófagos, fibroblastos, células epiteliais e endoteliais (Akira et al., 2006; Beutler, 2005; Kumar et al., 2009).

O gene para o receptor Toll foi descrito na década de 80 por Eric Wieschaus e Christiane Nüslein-Volhard, os quais ganharam o prêmio Nobel de Medicina e Filosofia em 1995. O receptor Toll foi descrito como um receptor transmembranar essencial para o estabelecimento da correta polaridade dorsoventral e desenvolvimento embrionário adequado da mosca Drosophila melanogaster. Em 1996, Lemaitre e Hoffmann verificaram que moscas com mutações neste receptor eram susceptiveis à infecção pelo fungo Aspergillus fumigatus, uma vez que mutações no gene Toll bloqueavam a indução do peptídeo antimicrobiano Drosomicina em resposta à infecção fúngica (Lemaitre et al., 1996). Mais tarde, no ano de 2000, Charles Janeway e Ruslan Medzhitov identificaram a presença de receptores homólogos ao Toll no genoma humano, os quais foram denominados Toll-like receptors (TLR). Atualmente sabe-se que os TLR são evolutivamente conservados desde o verme Caenorhabditis elegans até os mamíferos (Akira, Takeda, 2004; Beutler, 2004).

Foram identificados, até o momento, 10 e 13 membros da família de TLR em humanos e camundongos, respectivamente. Os TLR envolvidos na imunidade inata em humanos com seus respectivos ligantes são: TLR-1 (Lipoproteínas e produtos micobacterianos); TLR-2 (Peptideoglicano, lipoproteínas, produtos de bactérias Gram-positivas, zimosan); TLR-3 (Ácido ribonucleico (RNA) de fita-dupla viral); TLR-4 (Lipopolissacarídeo (LPS) de bactérias Gram-negativas, fibronectina); TLR-5 (Flagelina bacteriana); TLR-6 (Lipopeptídios bacterianos e ácidos lipoteicóicos); TLR-7 e TLR-8 (RNA monofilamentar viral); TLR-9 (CpG de DNA viral e bacteriano não metilado) (Akira et al., 2006; Beutler, 2005).

Os TLR 1, 2, 4, 5 e 6 são especializados no reconhecimento de produtos microbianos na membrana plasmática. Os TLR 3, 7, 8 e 9 são especializados na detecção viral e no reconhecimento de ácidos nucléicos 
localizados em compartimentos intracelulares, como nos endossomoslisossomos (Beutler, 2005; Kumar et al., 2009).

TLR são proteínas que possuem um domínio intracelular altamente conservado, conhecido como TIR (Toll/IL-1-receptor homologous region), o qual possui homologia com o domínio intracelular do receptor para IL-1, envolvido na interação proteína-proteína, necessário para iniciar a via de sinalização intracelular. O dominio extracelular, com repetições ricas em leucina (LRRs, Leucine-rich repeats), está relacionado ao reconhecimento do ligante (Arancibia et al., 2007).

A ligação dos TLR aos componentes microbianos aciona diferentes cascatas de sinalização que culminam na ativação de fatores de transcrição, como NF-kB e membros da família IRF (IFN-regulatory factor), levando a produção das citocinas TNF- $\alpha$, IL-6, IL-12, IL-1 $\beta$, IFN- $\alpha$, IFN- $\beta$ e CXCL10, além da expressão de moléculas coestimuladoras (CD80 e CD86), CD40 e moléculas do MHC (Kopp, Medzhitov, 1999).

O componente microbiano LPS representa um dos principais fatores de virulência expostos na membrana externa de bactérias Gram-negativas e é constituído por três regiões estruturais distintas: antígeno $\mathrm{O}$, core e o lipídio A. Dentre as respostas imunes mais bem caracterizadas em mamíferos está a resposta para o lipídio A, o componente bioativo da endotoxina ou LPS, sendo o desencadeador de uma forte resposta imune e o sinal de alerta precoce de infecção bacteriana (Medzhitov, Janeway, 2000; Raetz, 1993).

O reconhecimento do LPS pelo TLR-4 ocorre mediante a participação de outras moléculas. Primeiramente, o LPS liga-se a proteína ligante de LPS (LBP) solúvel e, assim, será reconhecido pelo CD14, que é abundantemente expresso na superfície de monócitos, mas também existe em forma solúvel no plasma, e este complexo LPS - LBP e CD14 associa-se ao TLR-4 gerando estímulo celular. Após a ligação do LPS, a LBP se dissocia do TLR-4. A proteína extracelular acessória MD2 é essencial para a expressão de TLR-4 na superficie celular, como no reconhecimento do LPS pelo TLR-4 e auxilia para uma sinalização eficiente induzida pelo LPS (Akira, Takeda, 2004). 
O reconhecimento do LPS pelo TLR-4 promove mudanças na sua conformação que resulta na aproximação de dois domínios TIR, permitindo o recrutamento de moléculas adaptadoras MyD88, TIRAP (TIR-domaincontaining adaptor molecule), conhecida também como MAL (MyD88-adaptorlike), TRAM (TRIF-related adaptor molecule) e SARM (sterile $\alpha$ - and armadillomotif-containing protein) (Akira, Takeda, 2004; Fitzgerald et al., 2001; Henneke, Golenbock, 2001; Horng et al., 2001; O’Neil, Bowie, 2007; Shimazu et al., 1999). Sendo assim, o determinante do tipo de sinalização é o uso seletivo de diferentes combinações de moléculas adaptadoras. As ativações dependentes da molécula MyD88 iniciam com o favorecimento da associação com a IRAK-4 (IL-1R-associated Kinase-4), mediante ligação entre os domínios de morte de cada uma dessas moléculas, que irá se ativar, levando a fosforilação de IRAK-1. Após a fosforilação de IRAK-1, esta se dissocia de MyD88 e fosforila TRAF-6 (TNFR-associated factor 6), ativando esta proteína adaptadora. TRAF-6, formando um complexo com TAB1 e TAB2/3, fosforila TAK-1 (TGF- $\beta$-activated kinase 1). Após a formação do complexo, a ativação de TAK-1 culmina na ativação das quinases IKKa e IKK $\beta$, que juntamente com a subunidade reguladora IKKY (NEMO), formam o complexo trimérico IKK. Este complexo catalisa a fosforilação de IkB, a proteína citoplasmática retentora do fator de transcrição $\mathrm{NF}-\kappa \mathrm{B}$. Em seguida à formação deste complexo, TAK1 ativa dois membros da família da MAP quinase (MAPK, mitogen-activated protein kinase), a JNK (JUN N-terminal quinase) e p38, levando a produção de citocinas pró-inflamatórias (TNF- $\alpha$,

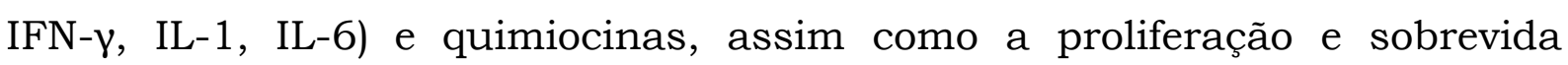
celular (Akira, Takeda, 2004; O’Neil, Bowie, 2007). 


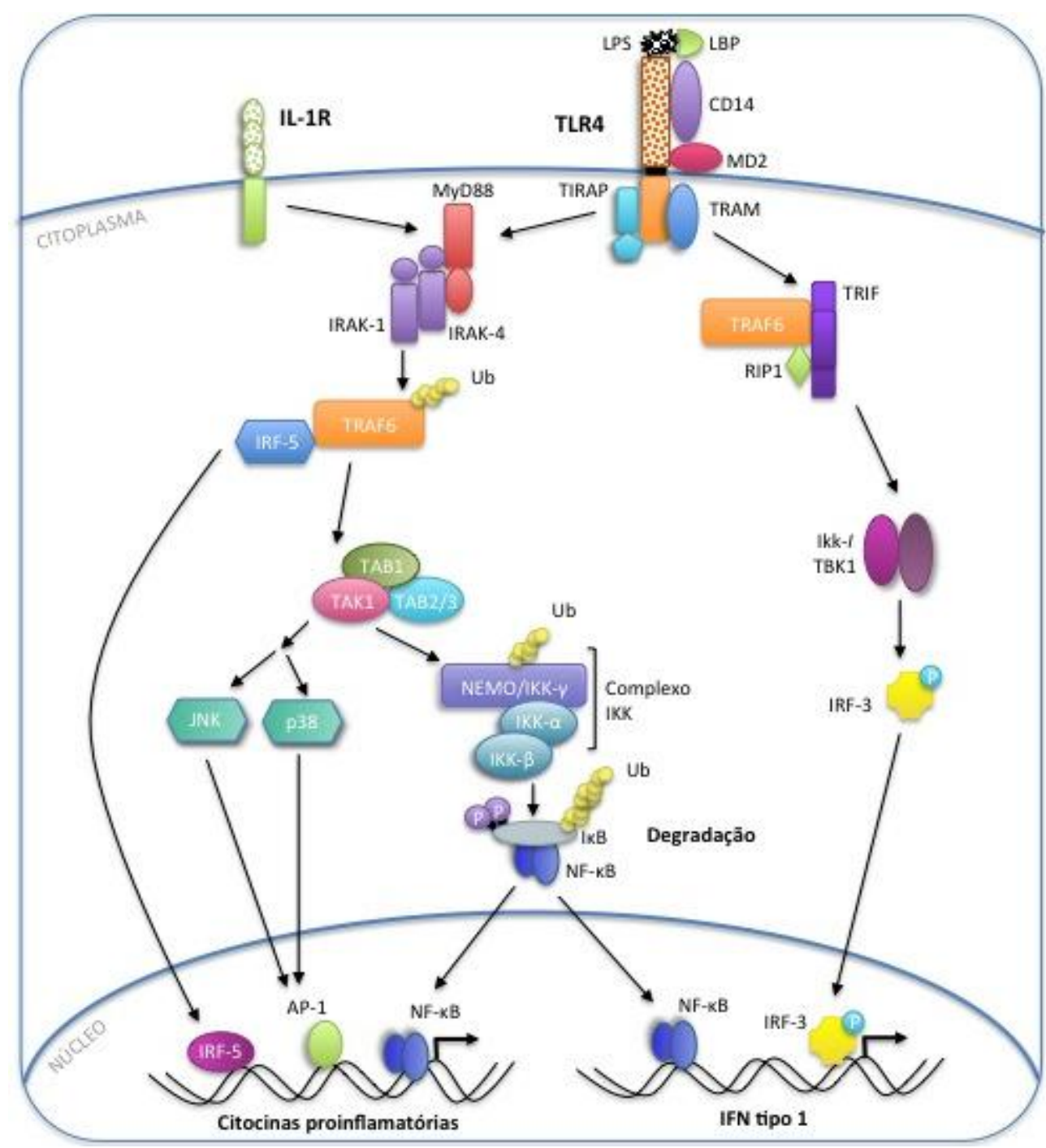

Figura 1: Visão esquemática da via de sinalização do receptor Toll-like 4 (TLR-4). O LPS interage com a proteína ligante de LPS (LBP) e liga-se ao TLR-4 na membrana celular com a ajuda do CD14 e MD2, levando à ativação da sinalização dependente e independente de MyD88 via diferentes proteínas adaptadoras. A via dependente de MyD88 sinaliza através das vias de ativação das quinases IKK e MAPK, que por sua vez conduzem à ativação dos fatores de transcrição $\mathrm{NF}-\kappa \mathrm{B}$ e AP-1, respectivamente, e controlam a expressão de citocinas pró-inflamatórias e outros genes relacionados ao sistema imune. A via independente de MyD88 é mediada pela proteína TRIF, que ativa IRF3 e induz a expressão de genes do IFN do tipo 1 (Adaptado de Akira et al., 2006).

$\mathrm{Na}$ ativação do NF-kB pela via independente de MyD88, a molécula adaptadora TRIF possui diferentes regiões de interação que juntamente com a participação da molécula TRAM levam ao recrutamento de diferentes moléculas efetoras como TBK-1, TRAF-6 e RIP-1. A interação entre TRIF, TRAF-6 e TBK-1 faz com que TRAF-6 ative o NF-kB, promovendo a 
fosforilação de IRF3, levando a produção de IFN do tipo 1 (Akira et al., 2003) (Figura 1).

\subsection{Monócitos Neonatais}

Os monócitos são importante fonte de citocinas no início da infecção microbiana e expressam uma variedade de receptores de reconhecimento de padrões, incluindo altos niveis de TLR-2 e TLR-4 (Geissmann et al., 2010).

Segundo estudo de Gordon e Taylor (2005), a morfologia dos monócitos maduros na circulação periférica é heterogênea, variando em tamanho, granulosidade e morfologia nuclear constituindo, aproximadamente, 5 a $10 \%$ dos leucócitos do sangue periférico em humanos.

O estudo recente de Yang et al. (2014) mostra a plasticidade e a heterogeneidade dos monócitos, que são divididos em 3 subtipos, baseados em seus marcadores de superficie e em suas funções específicas, que compreendem: monócitos inflamatórios clássicos, que são equipados com receptores Toll-like e receptores Scavenger, reconhecem PAMP, removem microrganismos, lipídios e destroem patógenos por meio da fagocitose. Os monócitos inflamatórios são aqueles que transitam no local da inflamação produzindo citocinas inflamatórias e contribuindo com a inflamação local e sistêmica, sendo altamente infiltrantes, podendo se diferenciar em macrófagos inflamatórios, os quais removem os resíduos celulares. Estes mesmos monócitos, em estágio estacionário, patrulham os vasos sanguíneos, monitorando os PAMP e tornam-se macrófagos residentes. Finalmente durante a inflamação estes se diferenciam em macrófagos anti-inflamatórios, os quais atuam no reparo de danos teciduais.

O reconhecimento microbiano por fagócitos estimula a fagocitose, atividade microbicida, produção de citocinas pró-inflamatórias e inicia o desenvolvimento da resposta imune adaptativa. Estudos descrevem a imaturidade do sistema imune adaptativo ao nascimento e sugerem que esta imaturidade está ligada a alterações funcionais na imunidade inata, as quais 
podem levar a deficiências secundárias nas respostas adaptativas de células T (Zinkernagel, 2001).

Está descrito que monócitos neonatais exibem baixa expressão basal das moléculas coestimuladoras CD86 e CD40, a qual não é aumentada por

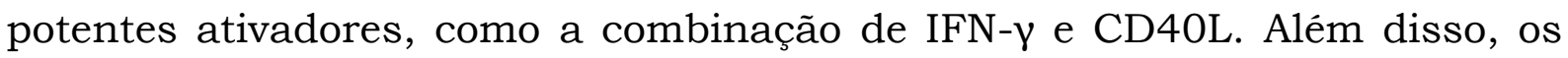
monócitos e macrófagos neonatais produzem baixos niveis de citocinas próinflamatórias, como TNF-a e IL-1 $\beta$, ou mesmo do padrão Th1, como a IL-12, em resposta ao LPS bacteriano (Hirschfeld et al., 2000). Essas alterações provavelmente resultam em vias de sinalização ligadas ao TLR não tão eficientes, mas a natureza destas deficiências ainda não está bem elucidada. Embora monócitos neonatais expressem mRNA para os diferentes TLR em níveis similares aos de monócitos de adultos, esses dados não excluem possiveis diferenças na expressão destes receptores devido a alterações póstranscricionais ou pós-transducionais (Hirschfeld et al., 2000).

RN apresentam níveis basais de IL-8 mais elevados quando comparados aos adultos, assim como os níveis de expressão do TLR-4 (Perez et al., 2010; Tadat et al., 2008; Thaxton et al., 2010). No entanto, monócitos em cultura de RN pré-termo apresentam menor produção de IL-8 quando comparados aos nascidos a termo, porém a expressão de TLR-4 é semelhante entre estes grupos de RN (Levy et al., 2004).

Sadeghi et al. (2007) revelaram em seu estudo que os RN pré-termo expressam niveis consideravelmente baixos de receptores TLR-4 e CD14 em monócitos, sendo acompanhados de uma reduzida expressão da proteína adaptadora MyD88 e das proteínas p38 e ERK1/2, além da diminuição da expressão do fator de transcrição IRF-5 em células mononucleares. Estas condições provavelmente contribuem para a resposta imatura dirigida aos componentes da membrana e parede celular bacteriana, LPS e ácido lipoteicóico (LTA), como indicado pela diminuição de síntese de IL-1ß, IL-6 e IL-8.

Ainda em relação aos RN pré-termo, foi mostrado que os monócitos estimulados em cultura apresentam produção reduzida de TNF- $\alpha$ e IL-12 em relação aos nascidos a termo. Ainda avaliando as citocinas produzidas por monócitos, Hartel et al. (2005) verificaram que RN prematuros apresentaram 


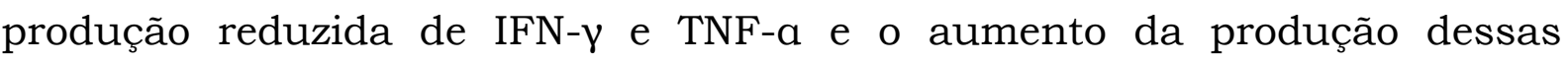
citocinas se correlaciona com a idade. No entanto, o nivel induzido de IL-6 é significativamente baixo em RN prematuros, especialmente naqueles nascidos antes de 30 semanas de gestação.

\subsection{Justificativa}

Apesar dos avanços na compreensão dos mecanismos que envolvem a liberação das citocinas mediante o estímulo dos receptores Toll-like, é escasso o conhecimento a respeito da função e da expressão deste sistema neste peculiar grupo que são os RN humanos pré-termos e, em particular, os pré-termo tardios, sendo uma população caracteristicamente de risco para a infecção microbiana e sepse.

A prematuridade é a segunda maior causa de morte em crianças menores de 5 anos e a mais importante causa direta de morte no crítico primeiro mês de vida. Mais de um em cada 10 bebês nascidos em todo o mundo em 2010 foram prematuros (antes de 37 semanas de gestação), resultando em um número estimado de 14,9 milhões de nascimentos prematuros. Destes, mais de um milhão morreram como resultado direto de sua prematuridade (Blencowe et al., 2012; Liu et al., 2012).

Os dados estatísticos mundiais mostram o preocupante quadro das infecções neonatais e das taxas de mortalidade que acometem os RN nas primeiras semanas de vida, especialmente os prematuros. Logo, unindo estes dados aos resultados das numerosas evidências da susceptibilidade dos neonatos humanos à invasão por diversos patógenos, e também à evidência da imaturidade funcional da resposta imune celular, inata e/ou adaptativa, reitera-se a busca de novos dados para uma melhor intervenção nos procedimentos de assistência pré-natal na prevenção de infecções e parto prematuro, de profilaxia intraparto e futuras terapêticas que evitem a morbidade e mortalidade neonatal. 
2 OBJETIVO 


\subsection{Objetivo geral}

Avaliar a ativação de monócitos de sangue de cordão umbilical de recém-nascidos a termo e pré-termo saudáveis mediante estimulação dos receptores do tipo Toll 4 (TLR-4).

\subsection{Objetivos especificos}

1. Avaliar as populações leucocitárias presentes no sangue de cordão umbilical;

2. Quantificar a expressão dos marcadores de ativação e das citocinas TNF$\alpha$, IL-1 $\beta$, IL-6, IL-8 e IL-10 em cultura de monócitos do sangue de cordão umbilical, estimulados ou não, via TLR-4;

3. Determinar a capacidade fagocitária e burst oxidativo dos fagócitos mono e polimorfonucleares presentes no sangue de cordão umbilical;

4. Determinar os niveis de expressão das proteínas envolvidas na via de sinalização intracelular, como ERK1/2, p38, IRAK-4 e do fator de transcrição $\mathrm{NF}-\kappa \mathrm{B}$ em cultura de monócitos do sangue de cordão umbilical, estimulados ou não, via TLR-4. 
3 METODOLOGIA 


\subsection{Casuistica}

A coleta foi efetuada no Centro Obstétrico do Hospital Universitário da Universidade de São Paulo-USP após aprovação pelo Comitê de Ética do Hospital Universitário (Registro CEP-HU/USP 914/09) e no Centro Obstétrico do Instituto Central do Hospital das Clinicas, após aprovação da Comissão de Ética para Análise de Projetos de Pesquisa do HC/FMUSPCAPPesq (Protocolo de pesquisa no 0101/10) e do Comitê de Ética em Pesquisa do Instituto de Ciências Biomédicas - ICB/USP (Parecer 929).

O Centro Obstétrico do Instituto Central do Hospital das Clínicas se caracteriza como um hospital terciário recebendo gestantes que fazem seu pré-natal no próprio hospital, como também vindas de outros hospitais da Capital, do interior ou de outros estados. Estas gestantes predominantemente possuem diversas patologias com relevante gravidade sendo, em grande parte, de etiologia infecciosa, as quais requerem acompanhamento e cuidados especiais durante o periodo gestacional, bem como no parto. Já o Centro Obstétrico do Hospital Universitário da Universidade de São Paulo tem o seu público predominantemente de gestantes sem patologias graves, as quais fizeram pré-natal no hospital ou vindas do Pronto Atendimento (PA) e de outros hospitais da Capital, como também de outros estados.

Foram colhidas para este trabalho amostras de sangue de cordão umbilical, sendo (17) amostras de RN pré-termo com idade gestacional <34 semanas, o qual foi denominado Grupo 1, (30) amostras de RN pré-termo $\geq 34$ e $<37$ semanas (Grupo 2) e (47) amostras de RN a termo $\geq 37$ semanas (Grupo 3).

A idade gestacional foi determinada considerando-se a data da última menstruação (DUM) e, quando não foi possivel, utilizando-se a ultrasonografia fetal realizada no primeiro trimestre. Na avaliação clínica da idade gestacional, quando surgiram dúvidas sobre a data da última menstruação e na ausência do exame de ultra-sonografia, foi utilizado o método de Capurro (1978) para os RN a termo e New Ballard (1991) para os RN pré-termo. 
As coletas de sangue de cordão umbilical foram realizadas em tubo com heparina para realização das culturas celulares de monócitos, avaliação do burst oxidativo e fagocitose; em tubo com EDTA para imunofenotipagem e em tubo com gel separador para a dosagem de citocinas e CD14s. Como controle dos experimentos foram coletadas amostras de adultos voluntários sem sintomas clínicos de infecção, entre 18 a 35 anos, dos sexos masculino e feminino, com reações sorológicas negativas para HIV, CMV, hepatite, sifilis, toxoplasmose, rubéola e herpes, pertencentes ao grupo do laboratório.

Foram realizadas análises dos prontuários das puérperas para escolha das possiveis doadoras, respeitando os seguintes critérios:

- Critérios de Inclusão: reações sorológicas negativas para HIV, CMV, hepatite, sifilis, toxoplasmose, rubéola e herpes;

- Critérios de Exclusão: sindromes genéticas, índice de Apgar inferior a 5 aos 5 minutos, evidências clínicas de corioamnionite, sinais clínicos e laboratoriais de infecção (marcadores de infecção elevados, como proteína Creativa, IL-8, IL-6; ruptura prévia de membranas por mais de 18 horas).

Após a análise dos prontuários e mediante o conhecimento prévio da pesquisa e autorização por escrito da mesma pelas puérperas, a coleta da amostra de sangue do cordão umbilical foi efetuada.

As amostras de sangue do cordão umbilical foram coletadas no período de junho de 2010 a dezembro de 2013. 


\subsection{Agonista do TLR-4}

Para a ativação do TLR-4, as culturas foram estimuladas utilizando o LPS ultra-puro de Escherichia coli O55 (List Biologicals, Campbell, USA), escolhido por não apresentar contaminação com proteínas e ácidos nucléicos que poderiam promover a ativação celular por outras vias que não a do TLR4 utilizado, após padronização, em uma concentração ideal de $10 \mathrm{ng} / \mathrm{mL}$ para a cultura de monócitos.

\subsection{Métodos}

\subsubsection{Dosagem de citocinas e CD14 solúvel em soro de cordão umbilical}

Foram analisados os dados do prontuário juntamente com os valores dos niveis basais das citocinas IL-1 $\beta$, IL-6, IL-8, IL-10, TNF- $\alpha$, IL-12p70, IL2, IL-4, IFN- $\gamma$ e IL-17A, dosadas nas amostras de soro, auxiliando na identificação de amostras de sangue de cordão umbilical de RN do Grupo 1, 2 e 3 que apresentassem infecção, sendo estes excluídos. O teste utilizado para a dosagem do soro foi o Cytometric Bead Array System (CBA) (BD Biosciences, San Jose, CA, USA), com os Kits pro-inflammatory e $\mathrm{T}_{\mathrm{H}} 1 / \mathrm{T}_{\mathrm{H}} 2 / \mathrm{T}_{\mathrm{H}} 17$.

Para realização do teste foi utilizado volume de $50 \mu \mathrm{L}$ de amostra de soro adicionadas a um pool de beads de captura específicas para todas as citocinas citadas. Também foi acrescentado o reagente de detecção conjugado com ficoeritrina (PE). Esses mesmos reagentes foram adicionados às diluições seriadas dos padrões das citocinas. Após 2 horas de incubação à temperatura ambiente, protegido da luz, todos os tubos foram lavados e analisados em citômetro de fluxo FACS LRS II Fortessa (BD Biosciences, San Jose, CA, USA), de acordo com a intensidade de fluorescência de cada bead de captura para cada citocina testada. Foram salvos 2.000 eventos em P1 onde as concentrações dessas citocinas, expressas em $\mathrm{pg} / \mathrm{mL}$, foram determinadas através da Mediana de Intensidade de Fluorescência de PE 
(MFI, median fluorescence intensity) e baseadas na curva padrão obtida para cada citocina.

A determinação dos níveis de CD14 solúvel (CD14s) nas amostras de soro de cordão umbilical dos RN do Grupo 1, 2 e 3 foi feita por meio da técnica de ELISA utilizando-se o kit DuoSet ${ }^{\circledR}$ Human CD14 (R\&D Systems, MN, USA), conforme as instruções do fabricante e os resultados expressos em ng/mL.

\subsubsection{Imunofenotipagem de leucócitos do sangue de cordão umbical}

As amostras de sangue foram colhidas em tubo contendo EDTA, lisadas com Lysing Buffer (BD Pharm LyseTM, BD Biosciences, San Jose, CA, USA), incubadas à temperatura ambiente por 20 minutos e centrifugadas a $1800 \mathrm{rpm}$ por 10 minutos a $10{ }^{\circ} \mathrm{C}$, por duas vezes. Em seguida foram realizadas 2 lavagens com Staining Buffer (PBS 7,4 acrescido de $1 \%$ de SFB e $0,1 \%$ de azida sódica) e centrifugação a $1800 \mathrm{rpm}$ por 10 minutos a temperatura ambiente. As células foram ressuspendidas em Staining Buffer e colocadas em microplaca de 96 poços na concentração de $1 \times 10^{6}$ células em $100 \mu \mathrm{L}$ de Staining Buffer. Os anticorpos (Tabelas 1 a 5) foram adicionados e a placa incubada por 30 minutos a temperatura ambiente e na ausência de luz. Em seguida, foram adicionados $100 \mu \mathrm{L} /$ poço de Staining Buffer, a placa foi centrifugada a $1800 \mathrm{rpm}$ por 5 minutos a 10 ${ }^{\circ} \mathrm{C}$, repetindo-se duas lavagens nas mesmas condições. Para leitura no citômetro de fluxo, as células foram ressuspendidas em $300 \mu \mathrm{L}$ de Staining Buffer em tubos de citometria e feita leitura utilizando o software BD FACSDiva. As diferentes populações celulares foram delimitadas utilizandose como parâmetro o tamanho - forward scatter (FSC) e a granulosidade celular - side scatter (SSC). A análise foi feita no software FlowJo, onde cada população celular foi analisada separadamente através de gates utilizandose como parâmetros o tamanho e a granulosidade celular.

As populações celulares foram calculadas através da multiplicação da porcentagem de cada população obtida na citometria de fluxo pelo número 
absoluto de leucócitos determinados pelo contador automático de células (Cell-Dyn CD-1700, Abbott Diagnostics, Lake Forest, IL, USA).

Tabela 1. Marcadores de superficie celular de células dendriticas mieloides e plasmocitoides.

\begin{tabular}{|c|c|c|c|}
\hline $\begin{array}{l}\text { Anticorpo } \\
\text { monoclonal }\end{array}$ & Clone & Fluorocromo & Fabricante \\
\hline Lineage* & * & FITC & BD Biosciences \\
\hline HLA-DR & G46-6 & V500 & BD Biosciences \\
\hline $\mathrm{CD} 11 \mathrm{c}$ & 3.9 & PE Cy5 & BioLegend** \\
\hline CD123 & $7 \mathrm{G} 3$ & $\mathrm{PE} \mathrm{Cy} 7$ & BD Biosciences \\
\hline CD1a & HI 149 & APC Cy7 & BioLegend \\
\hline CD80 & $2 \mathrm{D} 10$ & APC & BioLegend \\
\hline CD86 & 2331(FUN-1) & $\mathrm{PE}$ & BD Biosciences \\
\hline TLR-4 (CD284) & HTA 125 & PECy7 & BD Biosciences \\
\hline \multicolumn{4}{|c|}{$\begin{array}{l}\text { * Coquetel composto por anticorpos anti-CD3 (clone SK7), anti-CD14 (clone MФP9), anti } \\
\text { CD16 (clone 3G8), anti-CD19 (clone SJ25C1), anti-CD20 (clone L27), anti-CD56 (clon } \\
\text { NCAM16.2); }\end{array}$} \\
\hline
\end{tabular}

Tabela 2. Marcadores de superfície celular de monócitos.

\begin{tabular}{lccc}
\hline $\begin{array}{l}\text { Anticorpo } \\
\text { monoclonal }\end{array}$ & Clone & Fluorocromo & Fabricante \\
\hline HLA-DR & L243 & APC Cy7 & BD Biosciences \\
CD14 & M5E2 & Pacific blue & BD Biosciences \\
CD80 & BB1 & FITC & BD Biosciences \\
CD86 & $2331(F U N-1)$ & PE Cy5 & BD Biosciences \\
TLR-4 (CD284) & HTA125 & PE & Biolegend \\
\hline \hline
\end{tabular}


Tabela 3. Marcadores de superficie celular das subpopulações de linfócitos T naive, linfócitos T de memória central e linfócitos T de memória efetora.

\begin{tabular}{lccc}
\hline $\begin{array}{l}\text { Anticorpo } \\
\text { monoclonal }\end{array}$ & Clone & Fluorocromo & Fabricante \\
\hline CD3 & SK7 & APC Cy7 & BD Biosciences \\
CD4 & SK3 & PerCP & BD Biosciences \\
CD27 & M-T271 & FITC & BD Biosciences \\
CD45RA & HI100 & APC & BD Biosciences \\
CCR7 & $3 D 12$ & PE Cy7 & $B D$ Biosciences \\
CD62L & DREG-56 & PE & $B D$ Biosciences \\
\hline
\end{tabular}

Tabela 4. Marcadores de superfície celular da subpopulação de linfócitos T efetores.

\begin{tabular}{lccc}
\hline $\begin{array}{l}\text { Anticorpo } \\
\text { monoclonal }\end{array}$ & Clone & Fluorocromo & Fabricante \\
\hline CD3 & UCHT1 & V450 & BD Biosciences \\
CD4 & SK3 & APC Cy7 & BD Biosciences \\
CD69 & L78 & PECy7 & BD Biosciences \\
CD62L & DREG-56 & PE & BD Biosciences \\
\hline \hline
\end{tabular}

Tabela 5. Marcadores de superfície celular das subpopulações de linfócitos B naive, linfócitos B ativados e linfócitos B de memória.

\begin{tabular}{lccc}
\hline $\begin{array}{l}\text { Anticorpo } \\
\text { monoclonal }\end{array}$ & Clone & Fluorocromo & Fabricante \\
\hline CD19 & $4 \mathrm{G} 7$ & PerCP & BD Biosciences \\
CD27 & M-T271 & FITC & BD Biosciences \\
CD69 & DREG-56 & PECy7 & BD Biosciences \\
CD40 & 5 C3 & PE & BD Biosciences \\
TLR-4 (CD284) & HTA125 & Alexa 405 & Santa Cruz \\
\hline
\end{tabular}




\subsubsection{Estudo funcional da população de monócitos}

\subsubsection{Obtenção de células mononucleares de sangue de cordão umbilical}

A obtenção das células mononucleares do cordão umbilical dos RN (CBMC) e de sangue periférico de adultos (PBMC) foi realizada na câmara de fluxo laminar para manutenção da esterilidade celular.

As células mononucleares foram obtidas após centrifugação por 20 minutos a $2.000 \mathrm{rpm}$ por meio de gradiente de Ficoll Histopaque 1077 (Histopaque 1077 g/mL, Sigma, St. Louis, MO, USA). As células mononucleares obtidas nesta separação foram contadas no aparelho CellDyn CD-1700 (Abbott Diagnostics, Lake Forest, IL, USA) e a viabilidade celular foi verificada com corante Trypan Blue Solution (Sigma, St. Louis, MO, USA).

\subsubsection{Cultura de monócitos}

Após a obtenção das células mononucleares, as mesmas foram ressuspendidas em meio RPMI-1640 (Gibco ${ }^{\circledR}$, Life Technologies, Foster City, CA, USA) suplementado com L-Glutamina a $1 \%$, Gentamicina $(50 \mathrm{mg} / \mathrm{L})$ e Soro Fetal Bovino (SFB) a 10\% (meio R-10), e distribuídas em placas de 24 poços na concentração de $1 \times 10^{6}$ células/poço e mantidas a $37^{\circ} \mathrm{C}$ em estufa com $5 \%$ de $\mathrm{CO}_{2}$, overnight, para aderência dos monócitos. Em seguida, o sobrenadante contendo linfócitos foi retirado e os poços lavados 2 vezes com meio RPMI-1640 para retirar os linfócitos restantes. As células foram estimuladas com $10 \mathrm{ng} / \mathrm{mL}$ de LPS ultra-puro de Escherichia coli O55 (List Biologicals, Campbell, CA, USA) diluído em meio R-10. Os poços utilizados como controle negativo do teste não foram estimulados, sendo adicionado somente o meio R-10. O sobrenadante da cultura foi colhido após 18 horas de estímulo e armazenado em microtubos a $-80^{\circ} \mathrm{C}$ para posterior dosagem das citocinas. Em seguida, as placas foram submetidas a um banho de gelo por 10 minutos. 
Em ambiente não estéril, as células foram lavadas e ressuspendidas 3 vezes com Staining Buffer gelado. A suspensão de células contida em cada poço foi transferida para tubos de citometria, onde foram centrifugados a $1800 \mathrm{rpm}$ por 10 minutos. Em cada tubo, foram adicionados $100 \mu \mathrm{L}$ de Staining Buffer e feita marcação com os anticorpos monoclonais descritos na Tabela 6, selecionados e titulados previamente. Os tubos foram incubados por 30 minutos a temperatura ambiente em ausência de luz, em seguida 500 $\mu \mathrm{L}$ de Staining Buffer foram adicionados e os tubos centrifugados a $1800 \mathrm{rpm}$ por 5 minutos a $4^{\circ} \mathrm{C}$. O sobrenadante foi desprezado e as células foram lavadas 2 vezes nas mesmas condições. Para aquisição das células no citômetro de fluxo FACS LRS II Fortessa (BD Biosciences, San Jose, CA, USA), foram adicionados aos tubos $300 \mu \mathrm{L}$ de Staining Buffer onde a leitura foi efetuada salvando-se 10.000 eventos dentro do gate de monócitos HLA$\mathrm{DR}^{+} \mathrm{CD} 14^{+}$. Após a leitura, foram feitas as análises no software FlowJo (Tree Star, Ashland, OR, USA) e os dados foram apresentados em Mediana da Intensidade de Fluorescência (MFI).

Tabela 6. Marcadores de superficie celular dos monócitos cultivados.

\begin{tabular}{lccc}
\hline $\begin{array}{l}\text { Anticorpo } \\
\text { monoclonal }\end{array}$ & Clone & Fluorocromo & Fabricante \\
\hline HLA-DR & G46-6 & V500 & BD Biosciences \\
CD14 & M5E2 & Pacific blue & BD Biosciences \\
CD80 & BB1 & FITC & BD Biosciences \\
CD86 & $2331(F U N-1)$ & PECy5 & BD Biosciences \\
CD40 & 5 C3 & PE & BD Biosciences \\
TLR-4 (CD284) & HTA125 & PECy7 & $*$ * eBiosciences \\
\hline
\end{tabular}

*eBiosciences Inc. (San Diego, CA, USA) 
3.3.3.3 Dosagem de citocinas em sobrenadante de cultura de monócitos de sangue de cordão umbilical

No sobrenadante das culturas de monócito foram dosadas as concentrações de citocinas pró-inflamatórias TNF-a, IL-1 $\beta$, IL-6 e IL-8 e antiinflamatória IL-10 por meio do teste de CBA (Cytometric bead array, BD), método anteriormente descrito para dosagem das citocinas nas amostras de soro de cordão dos RN.

\subsubsection{Análise da função fagocitica e burst oxidativo por DHR (Dihidrorodamina 123)}

Ao analisar o burst oxidativo foi utilizada a substância Dihidrorodamina-123, que especificamente na presença do peróxido de hidrogênio $\left(\mathrm{H}_{2} \mathrm{O}_{2}\right)$ é oxidada convertendo-se em Rodamina-123, a qual é analisada por citometria de fluxo, juntamente com o teste de função fagocítica. Para este ensaio, foi utilizada a bactéria Escherichia coli marcada com iodeto de propídio, a qual foi gentilmente cedida pelo laboratório da Profa. Dra. Alice Maria Melville Paiva Della. Como controle positivo da reação foi utilizado o PMA (Phorbol 12-myristate 13-acetate, Sigma, St. Louis, MO, USA) (Rothe et al., 1988).

O ensaio de DHR foi realizado em condições ideais de esterilidade. Em microtubos, foram adicionados volumes adequados de sangue para que cada microtubo contivesse $1 \times 10^{6}$ leucócitos, os quais foram estimulados durante 20 minutos a $37^{\circ} \mathrm{C}$ e separadamente com $300 \mathrm{ng} / \mathrm{mL}$ de PMA e com E. coli na proporção de 10 microrganismos para 1 célula, ou não estimulados a fim de verificarmos a produção espontânea de $\mathrm{H}_{2} \mathrm{O}_{2}$. Em seguida, a DHR foi adicionada, a $500 \mathrm{ng} / \mathrm{mL}$, em todos os tubos e as amostras incubadas por 7 minutos a $37{ }^{\circ} \mathrm{C}$. Após este período, as amostras foram lavadas com $500 \mu \mathrm{L}$ de solução salina tamponada com fosfato (PBS) $\mathrm{pH} 7,4$ estéril e centrifugadas por 5 minutos a $1800 \mathrm{rpm}$ à temperatura ambiente. O sobrenadante foi desprezado e as hemácias foram lisadas duas vezes com BD FACSTM Lysing Solution (BD Biosciences, San Jose, CA, USA), 
permanecendo durante 20 minutos a temperatura ambiente e na ausência de luz. Em seguida as células foram lavadas duas vezes com PBS e ressuspendidas em $300 \mu \mathrm{L}$ da mesma solução.

A captação foi realizada no citômetro FACS LRS II Fortessa utilizandose como parâmetro o FSC e SSC, sendo salvos 2.000 eventos no gate de monócitos. As populações celulares foram analisadas no software FlowJo, onde monócitos e neutrófilos foram separados em diferentes gates. Os resultados foram expressos pela Média de Intensidade de Fluorescência (MFI).

\subsubsection{Quantificação da expressão das moléculas fosforiladas por citometria de fluxo}

Para a quantificação das moléculas ativadas (fosforiladas), ERK-1/2, NF- $\kappa$ B, p38 e IRAK-4, componentes da cascata de sinalização do TLR-4, foi utilizado o Kit Phosflow $\mathbb{R}$ que, por meio de citometria de fluxo, quantifica a expressão destas moléculas.

Foi realizada a cultura de monócitos descrita no Item 3.3.3.2., porém com período de estímulo de 20 minutos. Após a realização da marcação extracelular com anticorpo anti-CD14 (clone M5E2) conjugado a V500 e antiHLA-DR (clone L243) conjugado a APC-Cy7, foi feita uma lavagem com Staining Buffer e, em seguida, adicionado um volume pré-determinado de Fixation Buffer (BD ${ }^{\mathrm{TM}}$ Cytofix, Cat: 554655), de acordo com a quantidade de células $/ \mathrm{mL}\left(3 \times 10^{6}\right)$. Os tubos foram homogeneizados e incubados por 10 minutos a $37{ }^{\circ} \mathrm{C}$. Após este período, adicionaram-se aos tubos $100 \mu \mathrm{L}$ de Staining Buffer e os tubos foram centrifugados a $1800 \mathrm{rpm}$ por 5 minutos, a temperatura ambiente. Foi feita uma lavagem com Staining Buffer e o sobrenadante desprezado por inversão. Homogeneizou-se o pellet com o mínimo de tampão que restou no tubo. Duzentos microlitros de Perm Buffer II (BD ${ }^{\mathrm{TM}}$ Phosflow) foram adicionados para $3 \times 10^{6}$ células $/ \mathrm{mL}$, homogeneizados e incubados por 30 minutos a $4{ }^{\circ} \mathrm{C}$. Posteriormente, foram realizadas 3 lavagens adicionando-se $500 \mu \mathrm{L}$ de Staining Buffer e os tubos centrifugados a $1800 \mathrm{rpm}$ por 5 minutos, a temperatura ambiente. O sobrenadante foi 
desprezado por inversão e foram adicionados $100 \mu \mathrm{L}$ de Staining Buffer em cada tubo para a marcação intracelular com os anticorpos previamente selecionados, descritos na Tabela 7.

Os tubos foram incubados a temperatura ambiente por uma hora, protegidos da luz. Foram feitas duas lavagens adicionando-se $1 \mathrm{~mL}$ de Staining Buffer em cada tubo e o sobrenadante, desprezado. As células foram ressuspendidas em $200 \mu \mathrm{L}$ de tampão e foi feita a aquisição em citômetro de fluxo FACS LRS II Fortessa (BD Biosciences, San Jose, CA, USA), salvandose 20.000 eventos dentro do gate de monócitos CD14+HLA-DR ${ }^{+}$. As análises foram feitas no software FlowJo e os dados apresentados representam a Média da Intensidade de Fluorescência (MFI).

Tabela 7. Marcadores das moléculas intracelulares presentes na cascata de ativação celular da via do TLR-4.

\begin{tabular}{lccc}
\hline $\begin{array}{l}\text { Anticorpo } \\
\text { monoclonal }\end{array}$ & Clone & Fluorocromo & Fabricante \\
\hline ERK $1 / 2$ & $20 \mathrm{~A}$ & PerCP & BD Biosciences \\
NF- $\mathrm{kB}$ & $\mathrm{K} 10-895.12 .50$ & PECy7 & BD Biosciences \\
p38 & $36 / \mathrm{p} 38$ & Pacific Blue & BD Biosciences \\
IRAK-4 & (pT180/pY182) & & BD Biosciences \\
\hline \hline
\end{tabular}

\subsection{Análise estatística}

Para a análise estatística, os softwares GraphPad Prism 5.0 (GraphPad Software Inc., San Diego, CA, USA) e o MedCalc 12.7.0 (MedCalc Software, Ostend, Bélgica) foram utilizados. No presente trabalho, além da análise estatística descritiva, utilizada para calcular médias, medianas e desvios padrão, foram utilizados:

- Teste de Wilcoxon (para análise comparativa das medianas das amostras pré e pós-estímulo); 
- Teste de Mann-Whitney (para análise realizada entre diferentes grupos);

- Teste de Kruskal-Wallis (para análise comparativa das medianas dos 3 grupos de RN e de adultos), seguido do teste Post-hoc de Dunn. Foi adotado um nivel de significância de 5\%. 
4 Resultados 


\subsection{Grupo Amostral}

As amostras de sangue de cordão umbilical dos RN foram excluídas quando confirmada a presença de sinais de infecção, definidos pela dosagem de proteína $\mathrm{C}$ reativa, como também pelo estado clínico do neonato, além de mães com sinais indicativos de infecção amniótica, ou algum outro diagnóstico que poderia ocasionar alterações nos resultados em decorrência de um estado de ativação prévio do sistema imunológico. As mães com seus respectivos RN são citados nas Tabelas 8, 9, 10, 11 e 12, as quais contêm informações relevantes no processo de seleção, acima citado.

As amostras 1T e 1PT foram excluídas de nossa casuística por apresentarem resultados indicativos de infecção.

As amostras dos RN 8T, 12T e 13T foram descartadas da casuística em virtude da presença de infecção no trato urinário materno causada por Escherichia coli, infecção por Streptococcus do grupo B e infecção por Staphylococcus warneri, respectivamente. A amostra 3PT foi excluída devido à infecção do trato urinário materno, no entanto, a bactéria não foi isolada. Já a amostra 28PT foi descartada em virtude do diagnóstico materno de carcinoma de útero invasivo. As demais amostras com as análises dos dados obtidos dos prontuários das parturientes estão apresentadas nas Tabelas 8, 9, 10, 11 e 12 .

Os resultados da avaliação da proteína $\mathrm{C}$ reativa $(\mathrm{PCR})$ e dos niveis de citocinas pró-inflamatórias foram obtidos somente após a coleta e armazenamento das amostras. 
Tabela 8. Análise de prontuário das parturientes e seus respectivos RN pré-termo pertencentes ao Grupo 1.

\begin{tabular}{|c|c|c|c|c|c|c|}
\hline RN PT & $\begin{array}{c}\text { IG } \\
\text { (sem) }\end{array}$ & $\begin{array}{c}\text { Tipo de } \\
\text { parto }\end{array}$ & $\begin{array}{c}\text { Peso } \\
\text { RN (g) }\end{array}$ & $\begin{array}{c}\text { Apgar } \\
(1 / 5)\end{array}$ & $\begin{array}{l}\text { Doença } \\
\text { materna }\end{array}$ & $\begin{array}{c}\text { Bolsa } \\
\text { rota } \\
>18 h\end{array}$ \\
\hline 2PT & $330 / 7$ & Normal & 1930 & $8 / 9$ & Ausente & Não \\
\hline 3PT & $270 / 7$ & Normal & 960 & $5 / 8$ & Ausente & Não \\
\hline 8PT (1G) & $305 / 7$ & Cesárea & 1650 & $4 / 8$ & Presente 1 & Não \\
\hline $8 P T(2 G)$ & $305 / 7$ & Cesárea & 1500 & $2 / 8$ & Presente 1 & Não \\
\hline 14PT (1G) & $30^{1 / 7}$ & Normal & 1270 & $9 / 9$ & Ausente & Não \\
\hline 14PT (2G) & $30^{1 / 7}$ & Normal & 1400 & $9 / 10$ & Ausente & Não \\
\hline 15PT & $336 / 7$ & Cesárea & 1960 & $4 / 8$ & Presente ${ }^{2}$ & Sim \\
\hline 16 PT & $324 / 7$ & Cesárea & 1860 & $8 / 9$ & Ausente & Não \\
\hline 19PT & $32 \% / 7$ & Cesárea & 1690 & $8 / 9$ & Ausente & Não \\
\hline 21PT & $326 / 7$ & Cesárea & 950 & $8 / 10$ & Presente $1,3,4$ & Não \\
\hline 24PT & $335 / 7$ & Cesárea & 1390 & $9 / 10$ & Presente ${ }^{3}$ & Não \\
\hline 25PT & $30 \% / 7$ & Normal & 1500 & $9 / 10$ & Ausente & Não \\
\hline 27PT & $325 / 7$ & Cesárea & 1590 & $7 / 8$ & Ausente & Sim \\
\hline $28 P T$ & $33 \% / 7$ & Cesárea & 1370 & $7 / 9$ & Presente 6 & Não \\
\hline 31PT & $320 / 7$ & Normal & 1630 & $8 / 9$ & Ausente & Não \\
\hline 36PT & $33^{2} / 7$ & Normal & 1965 & $8 / 9$ & Presente ${ }^{3}$ & Não \\
\hline 37PT & $316 / 7$ & Cesárea & 1920 & $8 / 9$ & Ausente & Não \\
\hline
\end{tabular}

RN: recém-nascido; PT: pré-termo; IG: idade gestacional em semanas; g: gramas; 1G: primeiro gemelar; 2G: segundo gemelar; 1: Hipertensão Arterial Crônica; 2: Fibrose Pulmonar; 3: Doença Hipertensiva Específica da Gestação; 4: Cardiopatia; 5: Asma; 6: Carcinoma de útero invasivo. Amostras em vermelho foram excluídas.

Tabela 9. Análise de prontuário das parturientes e seus respectivos RN pré-termo pertencentes ao Grupo 2.

\begin{tabular}{lcccccc}
\hline RN PT & $\begin{array}{c}\text { IG } \\
\text { (sem) }\end{array}$ & $\begin{array}{c}\text { Tipo de } \\
\text { parto }\end{array}$ & $\begin{array}{c}\text { Peso } \\
\text { RN (g) }\end{array}$ & $\begin{array}{c}\text { Apgar } \\
\mathbf{( 1 / 5 )}\end{array}$ & $\begin{array}{c}\text { Doença } \\
\text { materna }\end{array}$ & $\begin{array}{c}\text { Bolsa } \\
\text { rota } \\
\text { >18h }\end{array}$ \\
\hline $\mathbf{1 P T}$ & $351 / 7$ & Normal & 2890 & $10 / 10$ & Ausente & Não \\
4PT (1G) & $36 \% / 7$ & Cesárea & 2595 & $8 / 10$ & Ausente & Não \\
4PT (2G) & $36 \% / 7$ & Cesárea & 2590 & $7 / 9$ & Ausente & Não \\
5PT & $354 / 7$ & Cesárea & 2740 & $10 / 10$ & Ausente & Não \\
6PT & $36 \% / 7$ & Cesárea & 2520 & $10 / 10$ & Ausente & Sim \\
\hline
\end{tabular}




\begin{tabular}{|c|c|c|c|c|c|c|}
\hline 7PT & $364 / 7$ & Fórcipe & 2990 & $9 / 10$ & Ausente & $\mathrm{Sim}$ \\
\hline 9PT (1G) & $362 / 7$ & Cesárea & 2410 & $8 / 9$ & Ausente & $\mathrm{Sim}$ \\
\hline 9PT (2G) & $362 / 7$ & Cesárea & 1810 & $9 / 9$ & Ausente & Sim \\
\hline 10PT & $35^{2 / 7}$ & Cesárea & 2705 & $9 / 9$ & Ausente & $\mathrm{Sim}$ \\
\hline $11 \mathrm{PT}$ & $35 \% / 7$ & Normal & 2430 & $7 / 9$ & Ausente & Não \\
\hline 12PT & $35^{3 / 7}$ & Normal & 2450 & $10 / 10$ & Ausente & Não \\
\hline 13PT & $35^{4 / 7}$ & Cesárea & 2180 & $7 / 9$ & Presente 3 & Não \\
\hline 17PT & $350 / 7$ & Cesárea & 2600 & $8 / 9$ & Presente 8 & Não \\
\hline 18PT & $342 / 7$ & Cesárea & 2240 & $4 / 8$ & Ausente & Não \\
\hline 20PT & $351 / 7$ & Cesárea & 1160 & $9 / 10$ & Ausente & Não \\
\hline 22PT & $345 / 7$ & Cesárea & 2050 & $8 / 9$ & Presente 3,5 & Sim \\
\hline 23PT & $36 \% / 7$ & Normal & 2650 & $9 / 10$ & Ausente & Sim \\
\hline 26PT & $35^{2} / 7$ & Normal & 1420 & $7 / 9$ & Ausente & Não \\
\hline 29PT & $35^{2} / 7$ & Normal & 2090 & $9 / 10$ & Presente $1,3,7$ & Não \\
\hline 30PT & $351 / 7$ & Cesárea & 2650 & $9 / 10$ & Ausente & Não \\
\hline 32PT & $34 \% / 7$ & Cesárea & 1780 & $9 / 10$ & Presente ${ }^{3}$ & Não \\
\hline 33PT & $342 / 7$ & Cesárea & 2180 & $9 / 10$ & Ausente & Não \\
\hline 34PT & $364 / 7$ & Normal & 2340 & $9 / 10$ & Presente 4 & Não \\
\hline 35PT(1G) & $341 / 7$ & Cesárea & 1960 & $7 / 9$ & Presente 9 & Não \\
\hline $35 P T(2 G)$ & $341 / 7$ & Cesárea & 1270 & $7 / 9$ & Presente ${ }^{9}$ & Não \\
\hline 38PT & $345 / 7$ & Normal & 2550 & $8 / 9$ & Presente 10 & Não \\
\hline 39PT & $36 \% / 7$ & Cesárea & 2295 & $3 / 7$ & Ausente & Não \\
\hline 40PT & $341 / 7$ & Normal & 2260 & $9 / 10$ & Presente 4 & Não \\
\hline
\end{tabular}

RN: recém-nascido; PT: pré-termo; IG: idade gestacional em semanas; g: gramas; 1G: primeiro gemelar; 2G: segundo gemelar; 1: Hipertensão Arterial Crônica; 3: Doença Hipertensiva Específica da Gestação; 4: Cardiopatia; 5: Asma; 7: Diabetes Mellitus; 8: Isoimunização RH; 9: Epilepsia; 10: Hipertireoidismo. Amostras em vermelho foram excluídas.

Tabela 10. Análise de prontuário das parturientes e seus respectivos $\mathrm{RN}$ a termo pertencentes ao Grupo 3.

\begin{tabular}{lcccccc}
\hline RN T & $\begin{array}{c}\text { IG } \\
\text { (sem) }\end{array}$ & $\begin{array}{c}\text { Tipo de } \\
\text { parto }\end{array}$ & $\begin{array}{c}\text { Peso } \\
\text { RN (g) }\end{array}$ & $\begin{array}{c}\text { Apgar } \\
\mathbf{( 1 / 5 )}\end{array}$ & $\begin{array}{c}\text { Doença } \\
\text { materna }\end{array}$ & $\begin{array}{c}\text { Bolsa } \\
\text { rota } \\
\text { > 18h }\end{array}$ \\
\hline $\mathbf{1 T}$ & $390 / 7$ & Normal & 2845 & $10 / 10$ & Ausente & Não \\
$\mathbf{2 T}$ & $376 / 7$ & Normal & 2945 & $10 / 10$ & Ausente & Não \\
$\mathbf{3 T}$ & $392 / 7$ & Cesárea & 2485 & $9 / 10$ & Ausente & Não \\
\hline
\end{tabular}




\begin{tabular}{|c|c|c|c|c|c|c|}
\hline $4 T$ & $400 / 7$ & Normal & 3945 & $9 / 10$ & Ausente & Não \\
\hline $5 T$ & $383 / 7$ & Cesárea & 3350 & $9 / 10$ & Ausente & Não \\
\hline $7 \mathrm{~T}$ & $376 / 7$ & Cesárea & 3555 & $7 / 9$ & Ausente & Não \\
\hline $8 T$ & $406 / 7$ & Normal & 3905 & $9 / 9$ & Ausente & $N a ̃ o$ \\
\hline $10 \mathrm{~T}$ & $410 / 7$ & Normal & 3200 & $9 / 10$ & Ausente & Não \\
\hline $11 \mathrm{~T}$ & $415 / 7$ & Cesárea & 3060 & $4 / 10$ & Ausente & Não \\
\hline $12 T$ & $410 / 7$ & Normal & 3550 & $9 / 10$ & Ausente & Não \\
\hline $13 T$ & $371 / 7$ & Normal & 2745 & $10 / 10$ & Ausente & Não \\
\hline $14 T$ & $376 / 7$ & Cesárea & 3060 & $4 / 10$ & Ausente & Não \\
\hline $15 T$ & $40 \% / 7$ & Normal & 3155 & $10 / 10$ & Ausente & Não \\
\hline $16 \mathrm{~T}$ & $376 / 7$ & Cesárea & 2620 & $9 / 9$ & Ausente & Não \\
\hline $17 \mathrm{~T}$ & $38^{4} / 7$ & Cesárea & 3290 & $8 / 9$ & Ausente & Não \\
\hline $19 T$ & $40 \% / 7$ & Cesárea & 3285 & $10 / 10$ & Ausente & Não \\
\hline 20T & $375 / 7$ & Normal & 3365 & $10 / 10$ & Ausente & Não \\
\hline $21 \mathrm{~T}$ & $41^{2} / 7$ & Normal & 3555 & $9 / 10$ & Ausente & Não \\
\hline $22 \mathrm{~T}$ & $391 / 7$ & Normal & 3470 & $9 / 10$ & Ausente & Não \\
\hline $23 T$ & $376 / 7$ & Normal & 2660 & $9 / 10$ & Ausente & Não \\
\hline $24 T$ & $391 / 7$ & Cesárea & 3300 & $10 / 10$ & Ausente & Não \\
\hline $25 \mathrm{~T}$ & $40 \% / 7$ & Normal & 3310 & $10 / 10$ & Ausente & Não \\
\hline $26 T$ & $390 / 7$ & Fórcipe & 3265 & $9 / 9$ & Ausente & Não \\
\hline $27 \mathrm{~T}$ & $392 / 7$ & Fórcipe & 2975 & $9 / 10$ & Ausente & Não \\
\hline $28 \mathrm{~T}$ & $382 / 7$ & Cesárea & 2610 & $9 / 10$ & Ausente & Não \\
\hline $29 \mathrm{~T}$ & $396 / 7$ & Cesárea & 3040 & $8 / 9$ & Ausente & Não \\
\hline 30T & $396 / 7$ & Cesárea & 3200 & $9 / 10$ & Ausente & Não \\
\hline $31 \mathrm{~T}$ & $39^{2} / 7$ & Cesárea & 4100 & $9 / 10$ & Ausente & Não \\
\hline $32 \mathrm{~T}$ & $40^{2} / 7$ & Fórcipe & 3395 & $9 / 10$ & Ausente & Não \\
\hline $33 \mathrm{~T}$ & $40^{4} / 7$ & Cesárea & 4330 & $9 / 10$ & Ausente & Não \\
\hline $34 \mathrm{~T}$ & 37 o/7 & Fórcipe & 2760 & $10 / 10$ & Ausente & Não \\
\hline $35 T$ & $400 / 7$ & Cesárea & 2890 & $9 / 10$ & Ausente & Não \\
\hline $36 \mathrm{~T}$ & $401 / 7$ & Cesárea & 3825 & $10 / 10$ & Ausente & Não \\
\hline $37 \mathrm{~T}$ & $390 / 7$ & Cesárea & 3920 & $10 / 10$ & Ausente & Não \\
\hline $38 T$ & $38^{2 / 7}$ & Normal & 3580 & $8 / 8$ & Ausente & Não \\
\hline $39 \mathrm{~T}$ & $385 / 7$ & Normal & 3327 & $9 / 10$ & Ausente & Não \\
\hline 40T & $386 / 7$ & Normal & 3720 & $9 / 10$ & Ausente & Não \\
\hline $41 \mathrm{~T}$ & $40^{3} / 7$ & Normal & 3280 & $9 / 10$ & Presente ${ }^{11}$ & Não \\
\hline
\end{tabular}




\begin{tabular}{lcllcll} 
42T & $375 / 7$ & Normal & 3145 & $9 / 10$ & Ausente & Não \\
43T & $39 \% / 7$ & Cesárea & 3290 & $8 / 9$ & Ausente & Não \\
44T & $396 / 7$ & Normal & 3360 & $10 / 10$ & Ausente & Não \\
45T & $37 \% / 7$ & Cesárea & 3000 & $8 / 9$ & Presente ${ }^{4}$ & Não \\
46T & $401 / 7$ & Normal & 3490 & $10 / 10$ & Presente $^{12}$ & Não \\
47T & $39 \% / 7$ & Normal & 2860 & $8 / 9$ & Presente $^{1}$ & Não \\
48T & $371 / 7$ & Cesárea & 4310 & $8 / 9$ & Presente 7,13 & Não \\
\hline \hline
\end{tabular}

RN: recém-nascido; T: termo; IG: idade gestacional em semanas; g: gramas; ${ }^{1}$ : Hipertensão Arterial Crônica; ${ }^{4}$ : Cardiopatia; ${ }^{7}$ : Diabetes Mellitus; ${ }^{11}$ : Hipertensão Arterial Sistêmica; ${ }^{12}$ : Sindrome Nefrótica; ${ }^{13}$ : Hipotireoidismo. Amostras em vermelho foram excluídas.

Tabela 11. Dados do prontuário das parturientes e seus respectivos RN nascidos pré-termo.

\begin{tabular}{|c|c|c|c|c|c|c|c|}
\hline \multirow[t]{2}{*}{ RN PT } & \multicolumn{3}{|c|}{ Morbidade Materna } & \multicolumn{4}{|c|}{ Exame laboratorial (RN) } \\
\hline & ITU & SGB & E. coli & $\begin{array}{c}\text { PCR } \\
\text { 1 'dia }\end{array}$ & $\begin{array}{c}\text { PCR } \\
\text { 2odia }\end{array}$ & $\begin{array}{c}\text { PCR } \\
\text { 3odia }\end{array}$ & HMC \\
\hline $1 P T$ & Ausente & Ausente & $N R$ & $<10$ & $<10$ & $N R$ & Negativa \\
\hline 2PT & Ausente & Ausente & NR & $<10$ & $<10$ & NR & Negativa \\
\hline $3 P T$ & Presente & $N R$ & $N R$ & $\geq 10$ & $\geq 10$ & $<10$ & Negativa \\
\hline 4PT (1G) & Ausente & Ausente & Ausente & NR & NR & NR & Negativa \\
\hline 4PT (2G) & Ausente & Ausente & Ausente & NR & NR & NR & Negativa \\
\hline 5PT & Ausente & Ausente & Ausente & $<10$ & $<10$ & NR & NR \\
\hline 6PT & Ausente & Ausente & Ausente & $\geq 10$ & $\geq 10$ & NR & Negativa \\
\hline 7PT & Ausente & Ausente & Ausente & $<10$ & $<10$ & NR & Negativa \\
\hline 8PT (1G) & NR & NR & NR & NR & NR & NR & NR \\
\hline $8 P T(2 G)$ & NR & NR & NR & NR & NR & NR & NR \\
\hline 9PT (1G) & NR & NR & NR & NR & NR & NR & NR \\
\hline 9PT (2G) & NR & NR & NR & NR & NR & NR & NR \\
\hline 10PT & Ausente & Ausente & Ausente & $<10$ & $<10$ & NR & Negativa \\
\hline 11PT & Ausente & Ausente & Ausente & $<10$ & NR & NR & NR \\
\hline $12 \mathrm{PT}$ & Ausente & Ausente & Ausente & $>10$ & 10 & $<10$ & Negativa \\
\hline 13PT & Ausente & NR & Ausente & NR & NR & NR & NR \\
\hline 14PT(1G) & Ausente & NR & NR & $<10$ & $<10$ & NR & Negativa \\
\hline 14PT(2G) & Ausente & NR & NR & $<10$ & $<10$ & NR & Negativa \\
\hline $15 P T$ & Ausente & Ausente & NR & $<10$ & $<10$ & NR & Negativa \\
\hline
\end{tabular}




\begin{tabular}{|c|c|c|c|c|c|c|c|}
\hline 16PT & Ausente & NR & NR & $<10$ & NR & NR & Negativa \\
\hline 17PT & Ausente & NR & NR & NR & NR & NR & NR \\
\hline 18PT & Ausente & NR & NR & $<10$ & NR & NR & Negativa \\
\hline 19PT & NR & NR & NR & NR & NR & NR & NR \\
\hline 20PT & NR & NR & NR & NR & NR & NR & NR \\
\hline 21PT & NR & NR & NR & $<10$ & $\geq 10$ & NR & Negativa \\
\hline 22PT & Ausente & NR & NR & NR & NR & NR & NR \\
\hline 23PT & Ausente & NR & NR & NR & $<10$ & NR & Negativa \\
\hline 24PT & Ausente & NR & NR & NR & NR & NR & NR \\
\hline 25PT & NR & NR & NR & NR & NR & NR & NR \\
\hline 26PT & Ausente & NR & NR & NR & $\mathrm{NR}$ & NR & NR \\
\hline 27PT & Ausente & Ausente & NR & NR & $<10$ & NR & Negativa \\
\hline $28 P T$ & $N R$ & Ausente & $N R$ & $N R$ & $N R$ & $N R$ & $N R$ \\
\hline 29PT & Ausente & Ausente & NR & $<10$ & $\geq 10$ & $\geq 10$ & Negativa \\
\hline 30PT & Ausente & Ausente & NR & $<10$ & $\geq 10$ & NR & Negativa \\
\hline 31PT & NR & NR & NR & NR & NR & NR & NR \\
\hline 32PT & Ausente & NR & NR & NR & NR & NR & NR \\
\hline 33PT & Presente & NR & NR & $<10$ & $\mathrm{NR}$ & NR & Negativa \\
\hline 34PT & Ausente & NR & NR & NR & NR & NR & NR \\
\hline 35PT(1G) & Ausente & NR & NR & NR & NR & NR & NR \\
\hline 35PT(2G) & Ausente & NR & NR & NR & NR & NR & NR \\
\hline 36PT & Ausente & NR & NR & NR & NR & NR & NR \\
\hline 37PT & Ausente & NR & NR & NR & $\mathrm{NR}$ & NR & NR \\
\hline 38PT & Ausente & NR & NR & NR & NR & NR & NR \\
\hline 39PT & Ausente & Ausente & NR & $<10$ & $<10$ & NR & Negativa \\
\hline 40PT & Ausente & Ausente & NR & $<10$ & $<10$ & NR & Negativa \\
\hline
\end{tabular}

RN: recém-nascido; PT: pré-termo; 1G: primeiro gemelar; 2G: segundo gemelar; ITU: infecção do trato urinário; SBG: Streptococcus do grupo B; E. coli: Escherichia coli; PCR: proteína C reativa; HMC: Hemocultura; NR: não realizada. 
Tabela 12. Dados do prontuário das parturientes e seus respectivos RN a termo.

\begin{tabular}{|c|c|c|c|c|c|c|c|}
\hline \multirow[t]{2}{*}{ RN T } & \multicolumn{3}{|c|}{ Morbidade Materna } & \multicolumn{4}{|c|}{ Exame laboratorial (RN) } \\
\hline & ITU & SGB & E. coli & $\begin{array}{c}\text { PCR } \\
\text { 1'dia }\end{array}$ & $\begin{array}{c}\text { PCR } \\
\text { 2'dia }\end{array}$ & $\begin{array}{c}\text { PCR } \\
\text { 3'dia }\end{array}$ & HMC \\
\hline $1 T$ & $N R$ & $N R$ & $N R$ & $N R$ & $N R$ & $N R$ & $N R$ \\
\hline $2 T$ & NR & NR & NR & NR & NR & NR & NR \\
\hline 3T & NR & NR & NR & NR & NR & NR & NR \\
\hline $4 T$ & NR & NR & NR & NR & NR & NR & NR \\
\hline $5 \mathbf{T}$ & NR & NR & NR & $<10$ & $<10$ & NR & Negativa \\
\hline $7 \mathbf{T}$ & NR & NR & NR & NR & NR & NR & NR \\
\hline $8 T$ & Presente & $N R$ & Presente & $N R$ & $N R$ & $N R$ & $N R$ \\
\hline $10 T$ & NR & NR & NR & NR & NR & NR & NR \\
\hline $11 \mathrm{~T}$ & NR & NR & NR & NR & NR & NR & NR \\
\hline $12 T$ & $N R$ & Presente & $N R$ & $N R$ & $N R$ & $N R$ & $N R$ \\
\hline $13 T$ & $N R$ & Presente* & $N R$ & $N R$ & $N R$ & $N R$ & $N R$ \\
\hline $14 \mathrm{~T}$ & NR & NR & NR & NR & NR & NR & NR \\
\hline $15 \mathrm{~T}$ & NR & NR & NR & NR & NR & NR & NR \\
\hline $16 \mathrm{~T}$ & NR & NR & NR & NR & NR & NR & NR \\
\hline $17 \mathrm{~T}$ & NR & NR & NR & NR & NR & NR & NR \\
\hline $19 \mathrm{~T}$ & NR & NR & NR & NR & NR & NR & NR \\
\hline $20 \mathrm{~T}$ & NR & NR & NR & NR & NR & NR & NR \\
\hline $21 \mathrm{~T}$ & NR & NR & NR & NR & NR & NR & NR \\
\hline $22 T$ & NR & NR & NR & NR & NR & NR & NR \\
\hline $23 T$ & NR & NR & NR & $<10$ & $<10$ & NR & Negativa \\
\hline $24 T$ & NR & NR & NR & NR & NR & NR & NR \\
\hline $25 T$ & NR & NR & NR & NR & NR & NR & NR \\
\hline $26 T$ & NR & NR & NR & NR & NR & NR & NR \\
\hline $27 \mathrm{~T}$ & NR & NR & NR & NR & NR & NR & NR \\
\hline $28 \mathrm{~T}$ & NR & NR & NR & NR & NR & NR & NR \\
\hline $29 T$ & NR & NR & NR & NR & NR & NR & NR \\
\hline $30 T$ & NR & NR & NR & NR & NR & NR & NR \\
\hline $31 \mathrm{~T}$ & NR & NR & NR & NR & NR & NR & NR \\
\hline $32 \mathrm{~T}$ & NR & NR & NR & NR & NR & NR & NR \\
\hline $33 T$ & NR & NR & NR & $<10$ & $\geq 10$ & $<10$ & Negativa \\
\hline 34T & NR & NR & NR & NR & NR & NR & NR \\
\hline $35 \mathrm{~T}$ & NR & NR & NR & NR & NR & NR & NR \\
\hline
\end{tabular}




\begin{tabular}{|c|c|c|c|c|c|c|c|}
\hline $36 \mathrm{~T}$ & NR & NR & NR & NR & NR & NR & NR \\
\hline 37T & NR & NR & NR & NR & NR & NR & NR \\
\hline $38 \mathrm{~T}$ & NR & NR & NR & NR & NR & NR & NR \\
\hline $39 \mathrm{~T}$ & NR & NR & NR & NR & NR & NR & NR \\
\hline $40 T$ & NR & NR & NR & NR & NR & NR & NR \\
\hline $41 T$ & NR & NR & NR & NR & NR & NR & NR \\
\hline $42 T$ & NR & NR & NR & NR & NR & NR & NR \\
\hline $43 T$ & NR & NR & NR & NR & NR & NR & NR \\
\hline $44 T$ & NR & NR & NR & NR & NR & NR & NR \\
\hline $45 T$ & NR & NR & NR & NR & NR & NR & NR \\
\hline $46 T$ & NR & NR & NR & NR & NR & NR & NR \\
\hline 47T & NR & NR & NR & NR & NR & NR & Negativa \\
\hline $48 T$ & NR & NR & NR & NR & NR & NR & NR \\
\hline
\end{tabular}

RN: recém-nascido; T: termo; 1G: primeiro gemelar; 2G: segundo gemelar; ITU: infecção do trato urinário; SBG: Streptococcus do grupo B; E. coli: Escherichia coli; PCR: proteína C reativa; HMC: Hemocultura; NR: não realizada; *: Staphylococcus warneri.

\subsection{Dosagem de citocinas e CD14s nas amostras de soro de cordão umbilical}

Todas as amostras de soro obtidas do sangue de cordão umbilical coletadas foram utilizadas para dosagem de citocinas, com objetivo de excluir as amostras que apresentassem níveis aumentados característicos de infecção. Os resultados estão demonstrados nas Tabelas 13, 14 e 15. 
Tabela 13. Dosagem de citocinas nas amostras de soro de RN pré-termo do Grupo 1.

\begin{tabular}{|c|c|c|c|c|c|c|c|c|c|}
\hline & \multicolumn{9}{|c|}{ Citocinas (pg/ml) } \\
\hline & IL-8 & IL-6 & IL-12 & IL-1 $\beta$ & IL-10 & TNF- $\alpha$ & IL-2 & IL-4 & IL-17A \\
\hline $2 P T$ & $>2500,0$ & 978,9 & 10,2 & 51,8 & 11,1 & $N D$ & $N R$ & $N R$ & $N R$ \\
\hline 3PT & $1.663,4$ & $1.104,3$ & 19,3 & 23,6 & 25,3 & $N D$ & $N R$ & $N R$ & $N R$ \\
\hline 8PT (1G) & 17,3 & 3,1 & ND & ND & ND & 1,3 & $\mathrm{ND}$ & $\mathrm{ND}$ & ND \\
\hline 8PT (2G) & 105,0 & 33,5 & ND & ND & 0,6 & 1,8 & $\mathrm{ND}$ & $\mathrm{ND}$ & ND \\
\hline 14PT(1G) & 403,1 & 55,0 & 3,4 & 3,3 & 1,7 & 0,4 & $\mathrm{ND}$ & $\mathrm{ND}$ & ND \\
\hline 14PT(2G) & 40,7 & 6,1 & 2,2 & 0,25 & 0,9 & 0,5 & $\mathrm{ND}$ & $\mathrm{ND}$ & ND \\
\hline 15PT & 9,8 & 1,4 & 2,1 & 0,4 & 1,2 & 1,0 & 4,2 & 2,2 & 296,9 \\
\hline 16PT & 38,3 & 4,6 & 6,1 & 0,9 & 2,1 & 0,9 & 2,0 & ND & ND \\
\hline 19PT & 53,9 & 17,7 & ND & 0,5 & ND & ND & 1,8 & $\mathrm{ND}$ & ND \\
\hline 21PT & 96,1 & 9,3 & 0,3 & 1,3 & 0,7 & 0,4 & 2,8 & 0,3 & ND \\
\hline 24PT & 39,5 & 17,8 & 0,1 & 0,9 & 1,0 & 0,8 & 4,2 & 5,1 & 15,7 \\
\hline 25PT & 32,8 & 20,4 & 0,4 & 0,6 & 1,9 & 1,4 & 3,6 & 4,6 & 13,7 \\
\hline 27PT & 17,0 & 10,8 & 0,5 & 0,4 & 4,1 & ND & 4,1 & 4,4 & 20,7 \\
\hline $28 P T$ & 10,9 & 1,1 & $N D$ & $N D$ & 0,1 & 0,2 & 4,3 & 5,0 & 21,4 \\
\hline 31PT & 402,9 & 296,8 & 0,3 & 0,8 & 5,3 & 0,1 & 4,1 & 4,5 & 20,7 \\
\hline 36PT & 26,7 & 2,2 & ND & ND & 0,8 & 0,6 & 1,2 & 1,0 & 12,9 \\
\hline 37PT & 12,6 & 1,6 & 0,7 & ND & 0,3 & 0,3 & 1,4 & 4,5 & 17,0 \\
\hline
\end{tabular}

PT: pré-termo; 1G: primeiro gemelar; 2G: segundo gemelar; ND: não detectado. As amostras marcadas em vermelho e itálico foram excluídas da casuística de acordo com o prontuário das mães. As amostras marcadas em azul e itálico foram excluídas da casuística de acordo com o resultado da dosagem de citocinas no soro dos RN.

Tabela 14. Dosagem de citocinas nas amostras de soro de RN pré-termo do Grupo 2.

\section{Citocinas (pg/ml)}

\begin{tabular}{lccccccccc}
\hline & IL-8 & IL-6 & IL-12 & IL-1 $\beta$ & IL-10 & TNF- $\boldsymbol{~}$ & IL-2 & IL-4 & IL-17A \\
\hline 4PT (1G) & 44,9 & ND & ND & ND & ND & ND & NR & NR & NR \\
4PT (2G) & 34,8 & 15,0 & 16,0 & ND & ND & ND & 2,0 & ND & ND \\
5PT & 52,9 & 19,0 & ND & ND & 8,4 & ND & NR & NR & NR \\
6PT & 173,2 & 118,5 & 0,9 & 6,4 & 1,1 & 1,4 & 1,3 & ND & ND \\
7PT & 24,8 & 8,2 & ND & ND & ND & 0,1 & ND & ND & ND \\
9PT (1G) & 20,9 & 3,1 & ND & 0,1 & 0,8 & 0,6 & ND & ND & ND \\
9PT (2G) & 16,5 & 6,6 & 0,5 & ND & 0,5 & 1,7 & 1,9 & ND & ND \\
10PT & 19,2 & 3,0 & 1,1 & 2,4 & 0,6 & 3,5 & 4,3 & 1,6 & 110,2 \\
1 1PT & 2500,0 & 241,7 & 0,3 & 32,3 & 2,7 & 0,8 & $N R$ & $N R$ & $N R$ \\
12PT & 490,0 & 241,6 & ND & ND & ND & ND & ND & 0,5 & ND \\
13PT & 8,1 & 10,3 & 2,2 & 0,3 & 0,5 & 1,0 & ND & 1,1 & ND \\
\hline
\end{tabular}




\begin{tabular}{lccccccccc}
\hline 17PT & 18,2 & 4,4 & 3,3 & 0,6 & 0,8 & 0,7 & 2,9 & $\mathrm{ND}$ & $\mathrm{ND}$ \\
18PT & 22,9 & 11,2 & 2,5 & 0,35 & 1,0 & 0,4 & $\mathrm{ND}$ & $\mathrm{ND}$ & $\mathrm{ND}$ \\
20PT & 115,0 & 27,3 & 0,3 & $\mathrm{ND}$ & 2,0 & 0,4 & 2,0 & $\mathrm{ND}$ & $\mathrm{ND}$ \\
22PT & 78,5 & 13,6 & 0,5 & 4,3 & 1,2 & 1,2 & $\mathrm{ND}$ & $\mathrm{ND}$ & $\mathrm{ND}$ \\
23PT & 14,5 & 4,0 & 0,3 & 0,5 & 0,3 & 0,1 & 3,5 & 4,9 & 17,7 \\
26PT & 30,8 & 7,5 & 0,3 & 0,8 & 0,1 & 0,1 & 4,3 & 4,0 & 33,2 \\
29PT & 16,0 & 2,6 & 0,1 & 1,8 & 1,1 & $\mathrm{ND}$ & 1,9 & 2,4 & 21,9 \\
30PT & 10,5 & 0,7 & 0,7 & 3,0 & 0,2 & 1,0 & 1,2 & $\mathrm{ND}$ & 4,8 \\
32PT & 14,2 & 2,5 & 0,1 & 0 & 0,2 & 0,7 & 2,0 & 2,6 & 121,2 \\
33PT & 23,0 & 0,8 & $\mathrm{ND}$ & $\mathrm{ND}$ & 0,8 & 0,5 & $\mathrm{ND}$ & $\mathrm{ND}$ & 6,0 \\
34PT & 1835,7 & 50,3 & 0,4 & 6,7 & 2,4 & 53,2 & 1,4 & 1,9 & 10,3 \\
35PT(1G) & 16,0 & 3,4 & $\mathrm{ND}$ & $\mathrm{ND}$ & 1,3 & 0,4 & 3,1 & 2,0 & 10,9 \\
35PT(2G) & 24,6 & 3,6 & 0,7 & $\mathrm{ND}$ & 1,5 & $\mathrm{ND}$ & $\mathrm{ND}$ & $\mathrm{ND}$ & $\mathrm{ND}$ \\
38PT & 18,6 & 4,3 & 1,2 & 6,1 & 0,5 & 0,8 & 4,0 & 4,3 & 14,0 \\
39PT & 21,3 & 2,1 & 1,1 & 0,4 & $\mathrm{ND}$ & $\mathrm{ND}$ & 2,8 & 3,9 & 124,8 \\
40PT & 21,2 & 11,0 & 0,8 & 0,7 & 0,7 & 0,2 & 3,5 & 4,4 & 119,9 \\
\hline \hline
\end{tabular}

PT: pré-termo; 1G: primeiro gemelar; 2G: segundo gemelar; ND: não detectado; NR: não realizado. As amostras marcadas em azul e itálico foram excluídas da casuística de acordo com o resultado da dosagem de citocinas no soro dos RN. As amostras marcadas em azul e itálico foram excluídas da casuística de acordo com o resultado da dosagem de citocinas no soro dos RN.

Tabela 15. Dosagem de citocinas nas amostras de soro de RN a termo do Grupo 3.

\section{Citocinas (pg/ml)}

\begin{tabular}{lccccccccc}
\hline & IL-8 & IL-6 & IL-12 & IL-1 $\beta$ & IL-10 & TNF- $\alpha$ & IL-2 & IL-4 & IL-17A \\
\hline \hline $2 T$ & 210,2 & 858,7 & 140,5 & $N D$ & 26,5 & 24,9 & $N R$ & $N R$ & $N R$ \\
$\mathbf{3 T}$ & 37,1 & 14,8 & 17,8 & ND & 18,6 & ND & 2,8 & ND & 38,4 \\
$\mathbf{4 T}$ & 33,9 & ND & ND & ND & 16,6 & ND & 1,7 & ND & ND \\
$\mathbf{5 T}$ & 38,7 & ND & 12,0 & ND & ND & ND & 1,7 & ND & ND \\
$\mathbf{7 T}$ & 45,6 & 22,2 & 0,0 & ND & ND & 0,8 & 3,1 & ND & ND \\
$\mathbf{8 T}$ & 187,4 & 21,6 & 0,3 & 3,8 & 4,8 & 0,5 & $N D$ & $N D$ & $N D$ \\
$\mathbf{1 0 T}$ & 1298,0 & 8,4 & 0,3 & 21,9 & ND & 0,6 & 1,4 & ND & 107,4 \\
$\mathbf{1 1 T}$ & 479,0 & 11,7 & 0,4 & 21,0 & 1,5 & ND & 2,4 & 0,4 & 57,6 \\
$\mathbf{1 2 T}$ & 687,9 & 6,8 & 0,4 & 17,2 & 0,7 & 0,1 & $N R$ & $N R$ & $N R$ \\
$\mathbf{1 3 T}$ & 347,6 & 726,1 & $N D$ & 15,1 & 3,0 & 0,8 & $N R$ & $N R$ & $N R$ \\
$\mathbf{1 4 T}$ & 35,4 & 10,0 & ND & 0,1 & 1,3 & 1,1 & ND & ND & ND \\
$\mathbf{1 5 T}$ & 108,3 & 167,2 & 0,3 & 8,6 & 1,0 & 1,5 & ND & 1,0 & 209,6 \\
$\mathbf{1 6 T}$ & 17,7 & 9,2 & 0,1 & 0,6 & 0,6 & 0,5 & 1,7 & 0,6 & ND \\
$\mathbf{1 7 T}$ & 244,1 & 3,2 & ND & 1,4 & 0,2 & 1,3 & ND & ND & ND \\
$\mathbf{1 9 T}$ & 12,7 & 6,0 & 0,9 & 1,1 & ND & 0,8 & 2,0 & 0,4 & ND \\
$\mathbf{2 0 T}$ & 137,7 & 4,9 & 1,1 & 0,7 & ND & 0,6 & ND & ND & ND \\
$\mathbf{2 1 T}$ & 214,9 & 238,7 & ND & 3,5 & 1,3 & 1,1 & ND & 0,6 & ND \\
$\mathbf{2 2 T}$ & 86,7 & 47,0 & ND & 0,7 & 0,6 & 1,5 & 2,7 & ND & ND
\end{tabular}




\begin{tabular}{|c|c|c|c|c|c|c|c|c|c|}
\hline 23T & 88,2 & 4,7 & ND & 1,5 & 0,4 & 1,3 & ND & ND & 104,5 \\
\hline $24 T$ & 224,5 & 4,0 & 0,5 & 1,9 & 0,9 & 0,9 & ND & ND & ND \\
\hline $25 \mathrm{~T}$ & 20,4 & 1,8 & ND & 1,3 & ND & ND & NR & NR & NR \\
\hline $26 \mathrm{~T}$ & 221,3 & 2,8 & 0,3 & 4,7 & ND & ND & ND & ND & 253,2 \\
\hline $27 \mathrm{~T}$ & 194,1 & 5,6 & ND & 19,9 & 0,2 & 0,7 & ND & ND & 87,3 \\
\hline $28 \mathrm{~T}$ & 16,6 & 2,3 & 0,3 & 1,5 & 0,4 & 0,4 & 1,6 & ND & ND \\
\hline $29 \mathrm{~T}$ & 17,8 & 2,0 & 1,5 & 1,0 & 0,6 & 1,0 & ND & ND & $\mathrm{ND}$ \\
\hline 30T & 201,9 & 0,7 & 1,0 & 2,7 & 0,5 & 1,3 & ND & ND & $\mathrm{ND}$ \\
\hline $31 \mathrm{~T}$ & 873,5 & 1,9 & 0,8 & 4,4 & 1,4 & ND & ND & ND & $\mathrm{ND}$ \\
\hline $32 \mathrm{~T}$ & 122,8 & 17,0 & 0,1 & 5,4 & 0,7 & 1,1 & ND & ND & ND \\
\hline 33T & 20,6 & 3,3 & 0,4 & 2,7 & 0,2 & 1,2 & 2,0 & ND & $\mathrm{ND}$ \\
\hline $34 T$ & $>2500,0$ & 32,0 & 4,4 & 29,3 & 1,5 & 1,8 & 1,8 & ND & 171,3 \\
\hline $35 \mathrm{~T}$ & 10,3 & 2,6 & ND & 0,7 & 0,5 & 0,1 & 3,4 & 4,0 & 16,6 \\
\hline $36 \mathrm{~T}$ & 17,0 & 2,5 & 0,3 & 1,4 & 0,8 & 0,6 & 4,2 & 5,9 & 19,7 \\
\hline 37T & 92,9 & 4,1 & 1,0 & 1,6 & 1,7 & 2,9 & 1,2 & 0,8 & 8,3 \\
\hline $38 \mathrm{~T}$ & 52,8 & 1,0 & 1,3 & 10,0 & 1,0 & 1,9 & 4,0 & 1,9 & 5,6 \\
\hline 39T & 119,6 & 9,3 & ND & 0,3 & 0,7 & 3,9 & 2,2 & 1,7 & 19,4 \\
\hline 40T & 210,7 & 4,1 & ND & 4,2 & 0,4 & 1,6 & 2,7 & 3,2 & 11,4 \\
\hline $41 \mathrm{~T}$ & 25,0 & 4,7 & 2,0 & 2,7 & 0,2 & 0,8 & 2,9 & 3,2 & 16,0 \\
\hline $42 T$ & 19,2 & 7,0 & 1,8 & 1,4 & 0,6 & 1,3 & 2,9 & 3,2 & 16,0 \\
\hline $43 T$ & 16,7 & 2,7 & 0,3 & 1,8 & 1,4 & 1,5 & 2,9 & 4,1 & 13,0 \\
\hline $44 T$ & 20,9 & 16,0 & 0,9 & 0,9 & 0,8 & 0,6 & 3,2 & 3,7 & 17,3 \\
\hline $45 T$ & 16,8 & 4,4 & 1,4 & 1,3 & 0,9 & 1,0 & 3,3 & 4,5 & 18,0 \\
\hline $46 T$ & 18,1 & 4,3 & 0,3 & 1,2 & 41,2 & 1,9 & 2,5 & 3,1 & 100,4 \\
\hline $47 \mathrm{~T}$ & 17,5 & 1,0 & 0,7 & 1,2 & 1,1 & 1,7 & 3,3 & 4,9 & 155,7 \\
\hline $48 \mathrm{~T}$ & 24,7 & 5,2 & 0,2 & 0,6 & 0,5 & 0,4 & ND & ND & ND \\
\hline
\end{tabular}

T: termo; ND: não detectado; NR: não realizado. As amostras marcadas em vermelho e itálico foram excluídas da casuística de acordo com o prontuário das mães. As amostras marcadas em azul e itálico foram excluídas da casuística de acordo com o resultado da dosagem de citocinas no soro dos RN.

Nas tabelas anteriores, os valores das dosagens IFN- $\gamma$ não foram descritos, pois não foram detectáveis no soro dos RN.

De acordo com os resultados obtidos nas dosagens de citocinas, juntamente com dados maternos e exames laboratoriais dos $\mathrm{RN}$, associados à literatura, algumas amostras foram excluídas da casuística. As amostras de soro dos RN 2PT, 3PT (presença de infecção do trato urinário) e 13T (infecção por Staphylococcus warneri) apresentaram altas concentrações de IL-8 e IL-6; as amostras 12T (associada à presença de infecção materna por SGB) e 11PT apresentaram altas concentrações de IL-8, sendo que, esta última, ainda apresentou uma concentração considerável de IL-6. Já o RN 2T apresentou alta concentração de IL-6. 
Foram realizadas análises comparativas entre os tipos de parto e os níveis de citocinas, os quais estão apresentados nos gráficos pela média das amostras agrupadas por tipo de parto, normal ou cesárea (Figura 2).
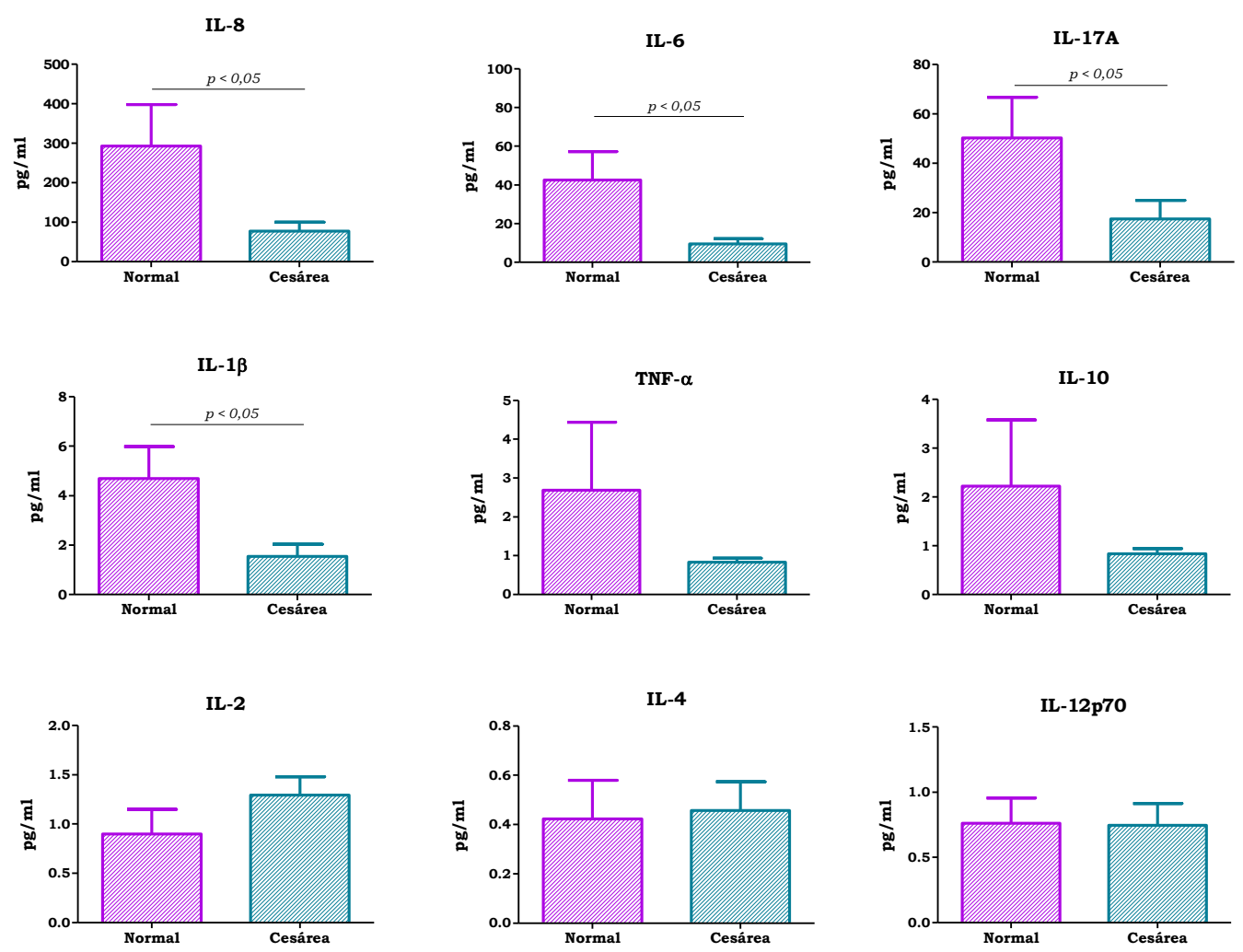

Figura 2. Concentrações séricas de IL-8, IL-6, IL-17A, IL-1 $\beta$, TNF- $\alpha$, IL-10, IL-2, IL4 e IL-12p70 em amostras de soro de cordão umbilical de RN pré-termo e a termo saudáveis. Parto normal $(n=34)$; Cesárea $(n=50)$.

Os dados das concentrações séricas de citocinas mostraram niveis significativamente mais elevados das citocinas pró-inflamatórias IL-8 e IL-6 no parto normal comparado à cesárea, assim como niveis mais elevados de IL-17A. Os niveis de IL- $1 \beta$ foram significativamente mais elevados no parto normal em relação à cesárea, porém em niveis mais reduzidos do que as outras citocinas inflamatórias, não ultrapassando $10 \mathrm{pg} / \mathrm{mL}$. O parto normal mostrou dosagens de citocinas TNF- $\alpha$ (pró-inflamatória) e a IL-10 (antiinflamatória) em níveis aumentados, porém não foram detectadas diferenças estatísticas com o grupo de parto cesárea. 
As concentrações de CD14s nas amostras de RN dos grupos 1, 2 e 3 estão na Figura 3. Os resultados revelaram concentrações crescentes de CD14s, de acordo com a idade gestacional, resultando em níveis significativamente maiores nos RN do Grupo 3 em relação ao Grupo 1.

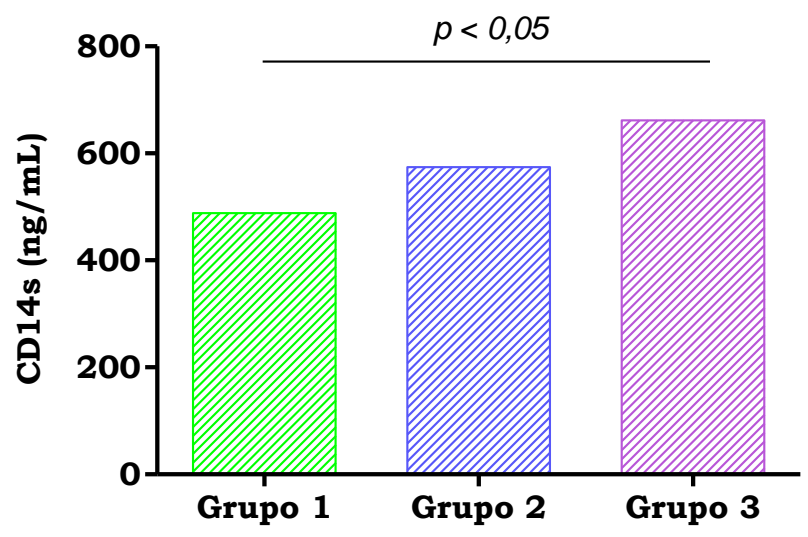

Figura 3. Concentrações de CD14 solúvel (CD14s) em amostras de soro de cordão umbilical dos RN dos Grupos 1 (n=12), $2(n=19)$ e $3(n=36)$.

As médias dos valores (valor mínimo e máximo) do peso e da idade gestacional dos RN do Grupo 1 (<34 semanas), Grupo $2(\geq 34$ e $<37)$ e Grupo 3 ( $\geq 37$ semanas), que foram utilizados no presente trabalho, estão representadas na Tabela 16.

Tabela 16. Médias dos pesos e das idades gestacionais dos Grupos de RN.

\begin{tabular}{lccc}
\hline & $\begin{array}{c}\text { Grupo 1 } \\
{[\mathbf{N = 1 4 ]}}\end{array}$ & $\begin{array}{c}\text { Grupo 2 } \\
{[\mathbf{N = 2 6 ]}}\end{array}$ & $\begin{array}{c}\text { Grupo 3 } \\
{[\mathbf{N = 4 0 ]}}\end{array}$ \\
\cline { 2 - 4 } & \multicolumn{3}{c}{$\begin{array}{c}\text { Média } \\
\text { (minimo - máximo) }\end{array}$} \\
\hline Peso (gramas) & 1591 & 2249 & 3308 \\
Idade gestacional & $(950-1965)$ & $(1160-2990)$ & $(2485-4330)$ \\
(semanas) & $316 / 7$ & $352 / 7$ & $391 / 7$ \\
\hline \hline
\end{tabular}

$\mathrm{N}$ : número amostral. 


\subsection{Imunofenotipagem de leucócitos do sangue de cordão umbilical}

A caracterização dos leucócitos foi realizada com 13 amostras de sangue de cordão umbilical de RN do Grupo 1, 21 amostras do Grupo 2, 22 amostras do Grupo 3 e 39 amostras de sangue periférico de adultos.

A análise estatística revelou que RN a termo (Grupo 3) apresentam maior número de leucócitos totais quando comparados aos RN pré-termos menores e maiores que 34 semanas de gestação e aos adultos $(p<0,05)$, dados mostrados na Tabela 17, a seguir. Em adição, adultos apresentam menor número de leucócitos quando comparados aos 3 grupos de RN.

Tabela 17. Números de leucócitos totais nas amostras de sangue de cordão umbilical de RN dos Grupos 1, 2 e 3 e no sangue periférico dos adultos.

\begin{tabular}{lcccc}
\hline & $\begin{array}{c}\text { Grupo 1 } \\
{[\mathbf{N = 1 3}]}\end{array}$ & $\begin{array}{c}\text { Grupo 2 } \\
{[\mathbf{N = 2 1 ]}}\end{array}$ & $\begin{array}{c}\text { Grupo 3 } \\
{[\mathbf{N = 2 2}]}\end{array}$ & $\begin{array}{c}\text { Adulto } \\
{[\mathbf{N}=\mathbf{3 9}]}\end{array}$ \\
\cline { 2 - 5 } & \multicolumn{4}{c}{ Média } \\
(minimo - máximo)
\end{tabular}

$\mathrm{N}$ : número de amostras; $\mathrm{N}^{\circ}$ : número. *: valor significativamente maior quando comparado aos outros grupos $(p<0,05)$. $\dagger$ : valor significativamente menor quando comparado aos outros grupos $(p<0,05)$.

As marcações para a caracterização das células dendríticas (DC) mieloides e plasmocitoides foram feitas no mesmo tubo, analisando também os marcadores de ativação celular. Os resultados foram expressos pela mediana do número absoluto de células dendriticas totais (Lin-HLA-DR+) e pela frequência (\%) de cada subpopulação de células dendríticas, descritas na Figura 4.

A população de DC das amostras de sangue de cordão umbilical e periférico de adulto foi definida como LIN-HLA-DR+, de acordo com Koumbi et al. (2010), e as populações mieloide (LIN-HLA-DR ${ }^{+}$CD $11 c^{+}$) e plasmocitoide $\left(\mathrm{LIN}^{-H L A}-\mathrm{DR}^{+} \mathrm{CD} 123^{+}\right)$foram caracterizadas como descrito por sorg et al. (1999) e Schreibelt et al. (2010). 
Os valores das medianas (mínimo - máximo) da frequência de células LIN-HLA-DR ${ }^{+}$do Grupo 1 foi 1,5\% (0,4 - 5,9); do Grupo 2: 1,4\% (0,6 - 6,1); Grupo 3: 1,8\% $(0,2-7,6)$ e do Adulto foi $0,5 \%(0,1-2,0)$ do total de células analisadas. O sangue periférico dos adultos apresentou frequência significativamente menor de células dendríticas totais quando comparado ao sangue de cordão de RN pré-termo e a termo.

A análise do número absoluto dos resultados mostrou que os RN dos três grupos apresentam maior número de DC quando comparados aos adultos.

Os RN do Grupo 3 apresentaram frequência significativamente menor de DC mieloides e plasmocitoides em relação aos outros grupos de RN e aos adultos e amostras de adultos apresentaram uma frequência significativamente maior de DC mieloides quando comparadas as do Grupo 2.

Não houve diferenças significativas entre os grupos quanto à expressão de CD1a, mas RN prematuros possuem uma tendência a expressar maior frequência de DC plasmocitoides imaturas em relação aos RN a termo. Ainda, observa-se uma maior porcentagem de DC plasmocitoides imaturas em relação às mieloides em todos os grupos. 

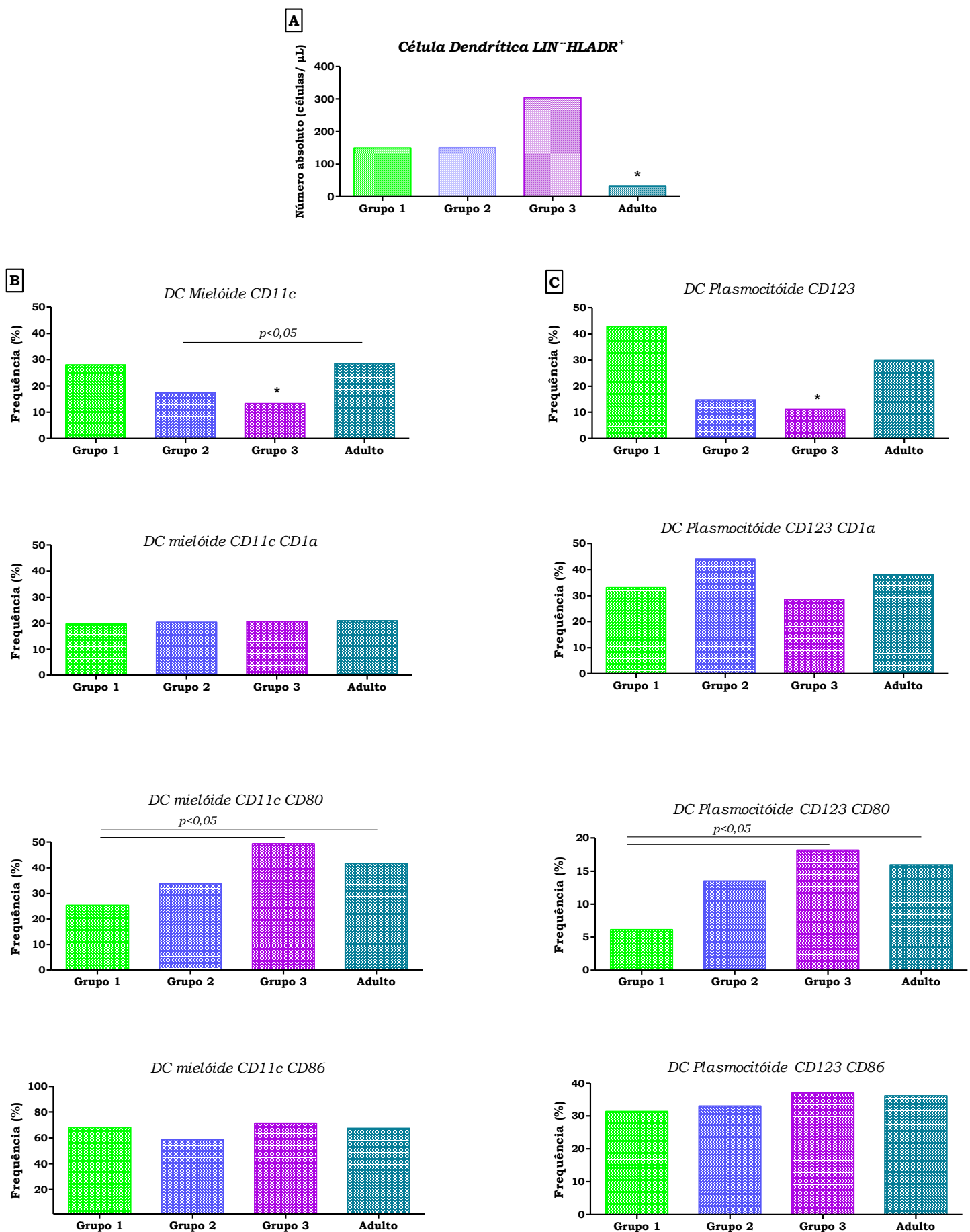

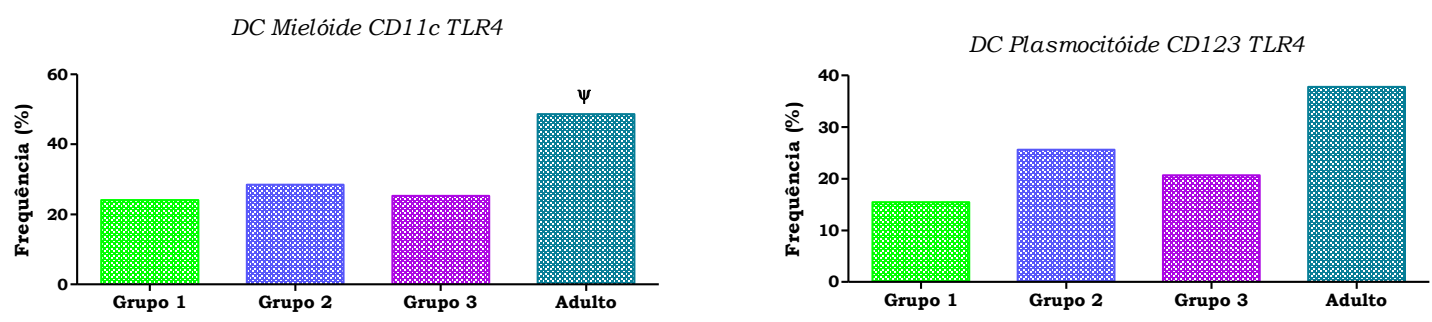

Figura 4. (A) Mediana do número absoluto (células/ $\mu$ ) das populações de células dendriticas totais (Lin-HLA-DR+); Frequência (\%) de células dendriticas mieloides CD11c (B) e plasmocitoides CD123 (C); imaturas (CD1a); expressando os marcadores CD80, CD86 e TLR-4 em amostras de sangue de cordão dos RN dos Grupos 1, 2 e 3 e de sangue de adultos. DC: célula dendrítica; *: valor significativamente menor quando comparado aos outros grupos $(p<0,05)$. $\psi$ : valor significativamente maior do adulto quando comparado aos $\mathrm{RN}(p<0,05)$. Os dados estão representados pela mediana dos valores.

Inversamente, foi observada uma maior proporção de DC mieloides expressando os marcadores de ativação celular CD80 e CD86 em relação às DC plasmocitoides para todos os grupos. Foi observado um aumento da expressão de CD80 nos dois tipos celulares, de acordo com a idade gestacional, com significativa menor expressão de CD80 em DC de RN prétermos do Grupo 1 em relação ao Grupo 3 e adultos. A expressão de CD86 em $\mathrm{mDC}$ e $\mathrm{pDC}$ foi semelhante entre os grupos. Foi observada uma frequência significativamente maior em adultos de $\mathrm{mDC}$ TLR-4+ ${ }^{+}$quando comparados aos grupos de RN, sendo que as pDC TLR-4+, embora tenha sido observada uma tendência a menor expressão nos RN, não foram detectadas diferenças significativas entre os grupos.

A Figura 5 mostra a mediana dos valores absolutos da população de monócitos e das frequências de monócitos $\mathrm{CD} 80^{+}, \mathrm{CD} 86^{+}$e TLR-4 ${ }^{+}$. Os valores das medianas (mínimo - máximo) da frequência de monócitos CD14+HLA-DR ${ }^{+}$do Grupo 1 representou 3,2\% (1,3 - 6,7); Grupo 2: 3,9\% (1,2 - 10,3); Grupo 3: 3,2\% (0,7 - 12,9) e Adulto: 2,7\% $(0,3$ - 7,7) do total de leucócitos analisados. 

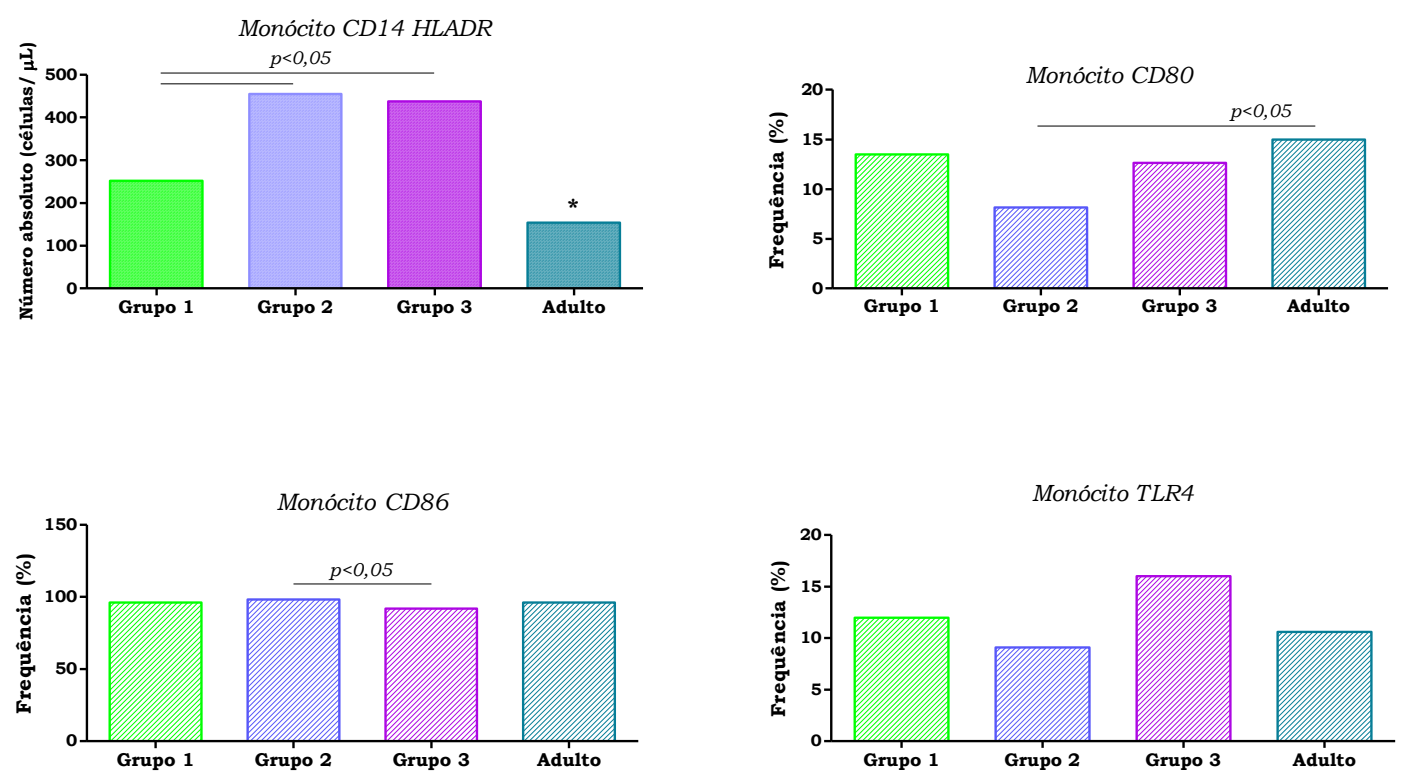

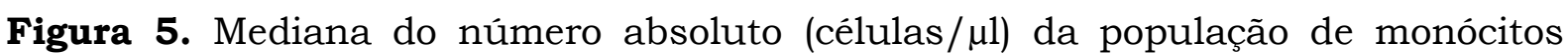
CD14+HLA-DR ${ }^{+}$e Mediana da Frequência (\%) dos marcadores de ativação celular CD80 e CD86, e TLR-4 em amostras de sangue de cordão umbilical dos RN dos Grupos 1, 2 e 3 e de sangue periférico de adultos. *: valor significativamente menor quando comparado com os grupos de $\mathrm{RN}(p<0,05)$. Os dados estão representados pelas medianas dos valores.

A população de monócitos foi definida pelo gate de células CD14+HLA$\mathrm{DR}^{+}$utilizando como parâmetro o tamanho (forward scatter, FSC) e a granulosidade celular (side scatter, SSC), assim como na cultura de monócitos, como descrito na literatura (Sánchez-Torres et al., 2001).

As análises mostraram números maiores de monócitos no sangue de cordão umbilical quando comparados ao sangue periférico de adultos. No entanto, o Grupo 1 apresentou número de monócitos significativamente menor quando comparado aos Grupos 2 e 3.

Em todos os grupos, a frequência de monócitos que expressam CD80 foi reduzida e, em contrapartida, CD86 é amplamente expresso nesta população celular. RN do Grupo 2 apresentaram menor expressão do marcador CD80 em relação ao adulto e os RN do Grupo 3 revelaram menor expressão de CD86 em relação ao Grupo 2.

Com relação à expressão de TLR-4 nos monócitos, não foram observadas diferenças estatisticamente significativas. 
A seguir, na Figura 6, estão representados os linfócitos $\mathrm{T}$ helper $\mathrm{CD}^{+} \mathrm{CD}^{+}$, expressos pela mediana do número absoluto destas células, e as medianas das frequências das subpopulações de linfócitos T CD4. Os valores das medianas (mínimo - máximo) da frequência da população de linfócitos T $\mathrm{CD}^{+}{ }^{+} \mathrm{CD}^{+}{ }^{+}$representaram no Grupo 1: 43,3\% (14,4 - 50,0); Grupo 2: 42,1\% $(21,2$ - 62,4); Grupo 3: 36,8\% (23,2 - 50,2) e adultos: 41,9\% $(27,6$ - 59,1) do total de linfócitos analisados.

Neste estudo, foram adotados na análise, os mesmos conjuntos de marcadores citados por Tanel et al. (2009), a fim de determinar as diferentes subpopulações de células $T$.

O sangue de cordão umbilical apresentou números significativamente maiores de linfócitos $\mathrm{T} \mathrm{CD}^{+} \mathrm{CD}^{+}$em relação ao adulto.

Quanto às várias subpopulações de linfócitos, a frequência de linfócitos T naïve é maior nos 3 grupos de RN quando comparados ao adulto que, por sua vez, apresentou maior frequência de linfócitos $\mathrm{T}$ efetores e de memória efetora quando comparado aos RN. Com relação aos linfócitos T de memória central, os valores percentuais foram equivalentes entre os grupos. 

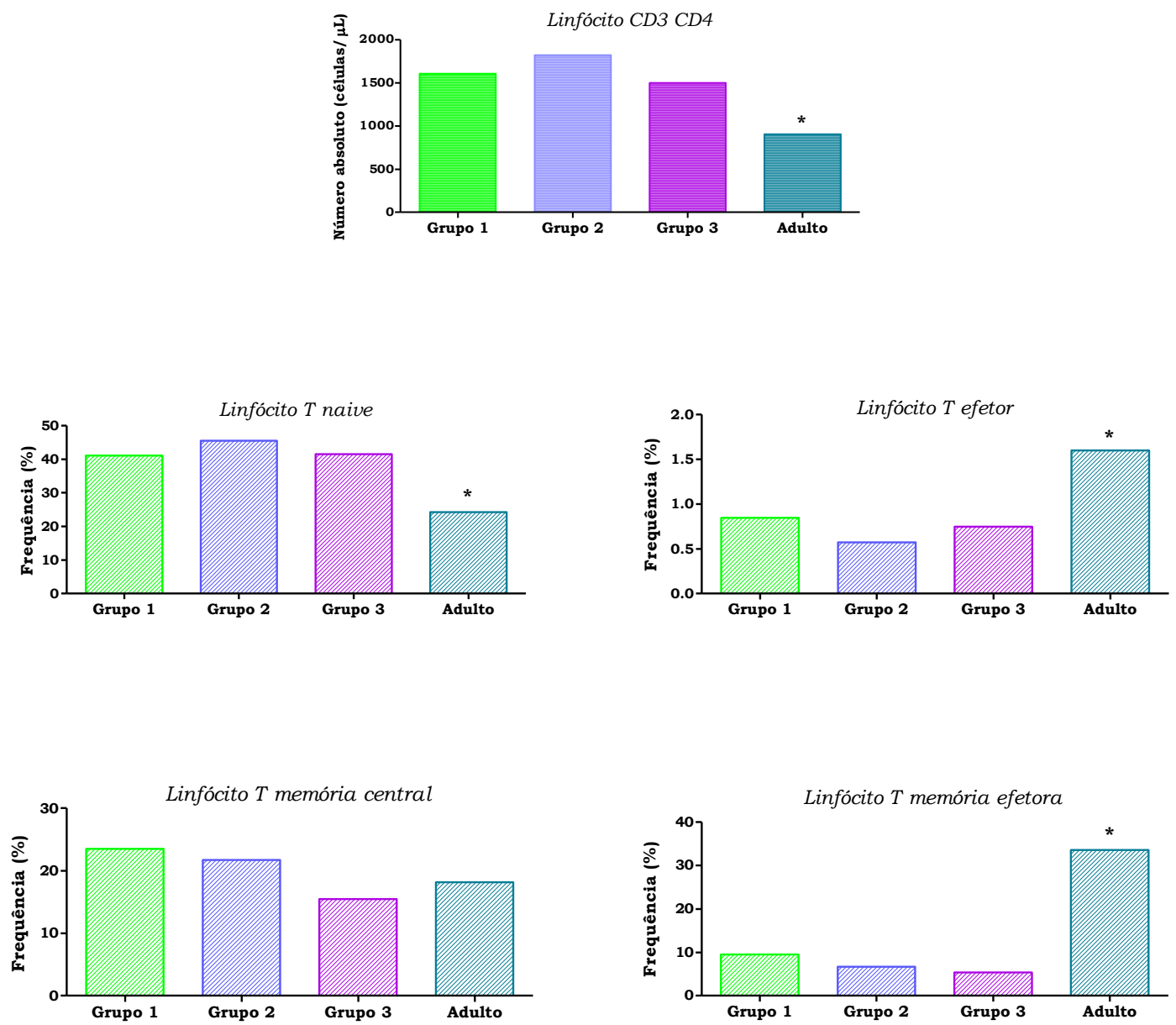

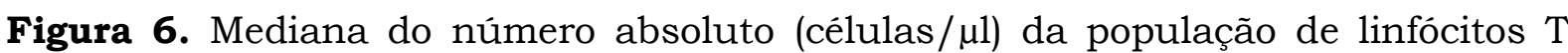
$\mathrm{CD}^{+}{ }^{+} \mathrm{CD}^{+}{ }^{+}$e mediana das frequências $(\%)$ das subpopulações de linfócitos T CD4 caracterizados pelos seguintes marcadores: Linfócito T naive: $\quad \mathrm{CD} 4{ }^{+} \mathrm{CD} 27+\mathrm{CD} 45 \mathrm{RA}+\mathrm{CCR} 7{ }^{+} \mathrm{CD} 62 \mathrm{~L}+$; Linfócito $\mathrm{T}$ efetor: CD4 ${ }^{+}$CD62 ${ }^{\text {Low }}{ }^{2}$ 69 ${ }^{+}$; Linfócito $\mathrm{T}$ memória central: $\mathrm{CD} 4{ }^{+} \mathrm{CD} 27^{+} \mathrm{CD} 45 \mathrm{RA}{ }^{-}$ $\mathrm{CCR}^{+}$; Linfócito $\mathrm{T}$ memória efetora: $\mathrm{CD} 4{ }^{+} \mathrm{CD} 27^{+} \mathrm{CD} 45 \mathrm{RA}-\mathrm{CCR} 7-\mathrm{em}$ amostras de sangue de cordão umbilical dos RN dos Grupos 1, 2 e 3 e de sangue periférico de adultos. *: diferença estatística do adulto quando comparado aos grupos de RN $(p<0,05)$. Os dados estão representados pelas medianas dos valores.

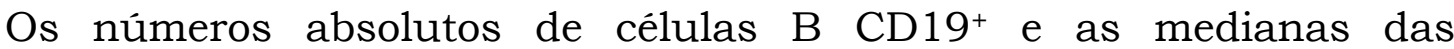
frequências das subpopulações destas células estão descritos na Figura 7. A análise da frequência de células $\mathrm{B} C D 19^{+}$resultou em uma mediana (mínimo - máximo) de 16,1\% (6,8 - 26,6) para o Grupo 1; Grupo 2: 11,5\% (4,5 - 30,7); Grupo 3: $12,6 \%(6,5$ - 26,9) e adultos: $11,1 \%(2,4-28,0)$ do total de linfócitos analisados. 

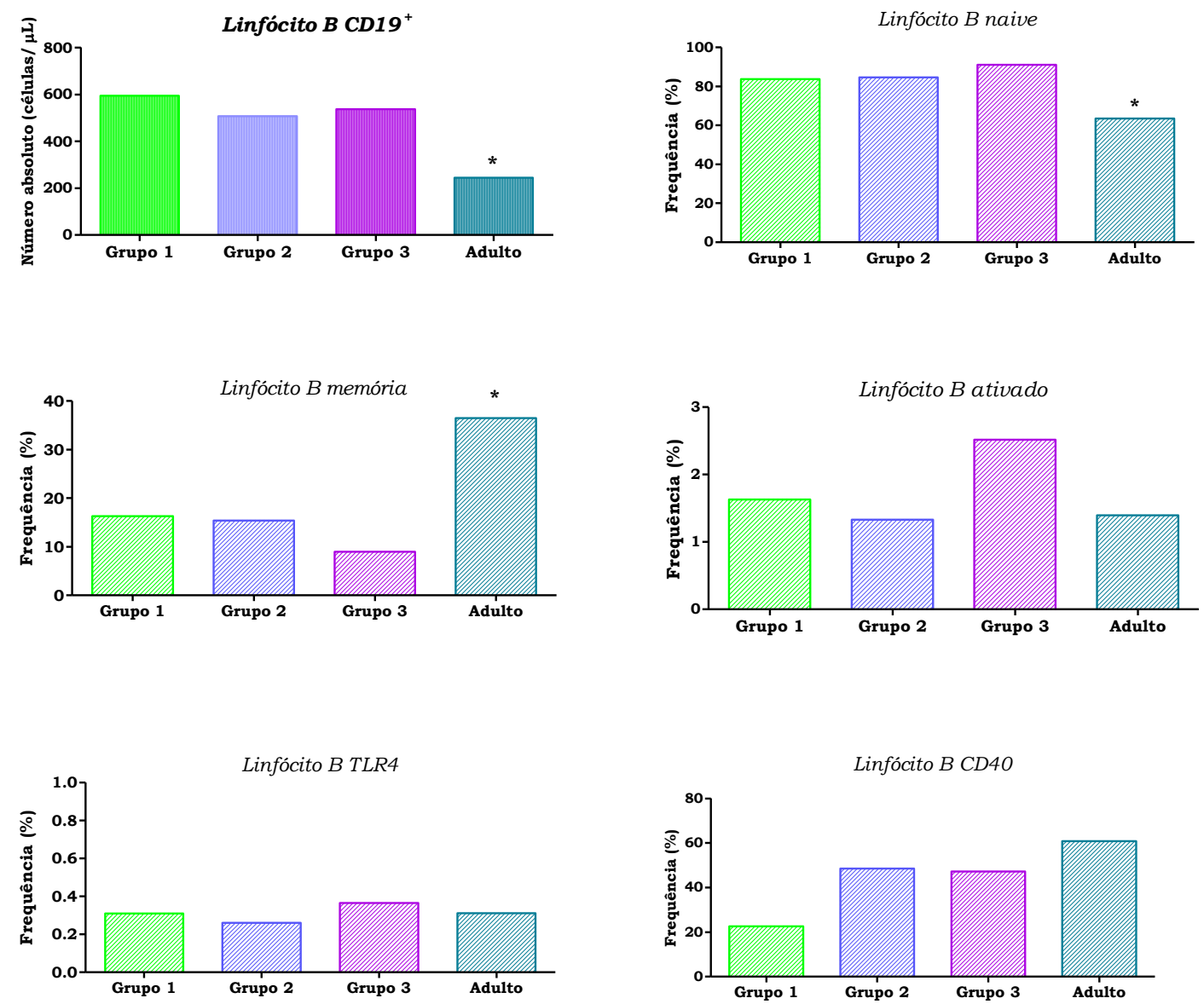

Figura 7. Mediana do número absoluto (células/ $\mu \mathrm{L}$ ) dos linfócitos $\mathrm{B} \mathrm{CD}_{19}{ }^{+}$em amostras de sangue de cordão umbilical dos RN dos Grupos 1, 2 e 3 e de sangue periférico de adultos. Mediana da frequência das subpopulações de linfócito $B$ caracterizadas pelos seguintes marcadores: Linfócito B naive: $\mathrm{CD} 19{ }^{+} \mathrm{CD} 27-$; Linfócito B de memória: CD19+CD27+; Linfócito $B$ ativado: CD19 ${ }^{+} \mathrm{CD} 69{ }^{+} \mathrm{CD} 40+$; Linfócitos expressando TLR-4 e CD40. *: diferença estatística do adulto quando comparado aos grupos de $\mathrm{RN}(p<0,05)$. Os dados estão representados pelas medianas dos valores.

Foi observado um número significativamente maior de linfócitos $\mathrm{B}$ nas amostras de RN dos 3 grupos quando comparados as amostras de adulto, bem como as porcentagens de linfócitos $\mathrm{B}$ naive e, de modo inverso, os RN apresentaram menor frequência de linfócitos B de memória em relação aos adultos. As frequências de linfócitos B ativados foram muito reduzidas em todos os grupos, inclusive nos adultos, e nenhuma diferença estatística foi detectada entre os grupos. 
No que diz respeito à expressão do TLR-4, foram observadas frequências muito baixas de células B expressando esse marcador em todos os grupos, inclusive nos adultos, sem diferenças estatísticas entre os grupos. Quanto à expressão do marcador CD40, o Grupo 1 apresentou uma tendência a uma menor frequência de células $\mathrm{B} \mathrm{CD} 40^{+}$.

\subsection{Estudo funcional dos monócitos}

As culturas de monócitos foram realizadas utilizando amostras de sangue de cordão umbilical, sendo 9 amostras do Grupo 1, 14 do Grupo 2 e 24 amostras do Grupo 3, acompanhadas de 24 amostras de sangue periférico de adultos saudáveis.

A aquisição das culturas no citômetro de fluxo foi realizada utilizando como parâmetros o tamanho FSC (forward scatter) e a granulosidade celular SSC (side scatter), como descrito por Sánchez-Torres et al. (2001). As análises destas culturas no software FlowJo revelaram que aproximadamente $70 \%$ das células são monócitos CD14+HLA-DR ${ }^{+}$.

A Figura 8 mostra a expressão dos marcadores de ativação celular CD80, CD86 e CD40 em monócitos estimulados e não estimulados, cultivados por 18 horas, bem como a expressão de TLR-4 e HLA-DR, demonstrados através da mediana da intensidade de fluorescência (MFI). 

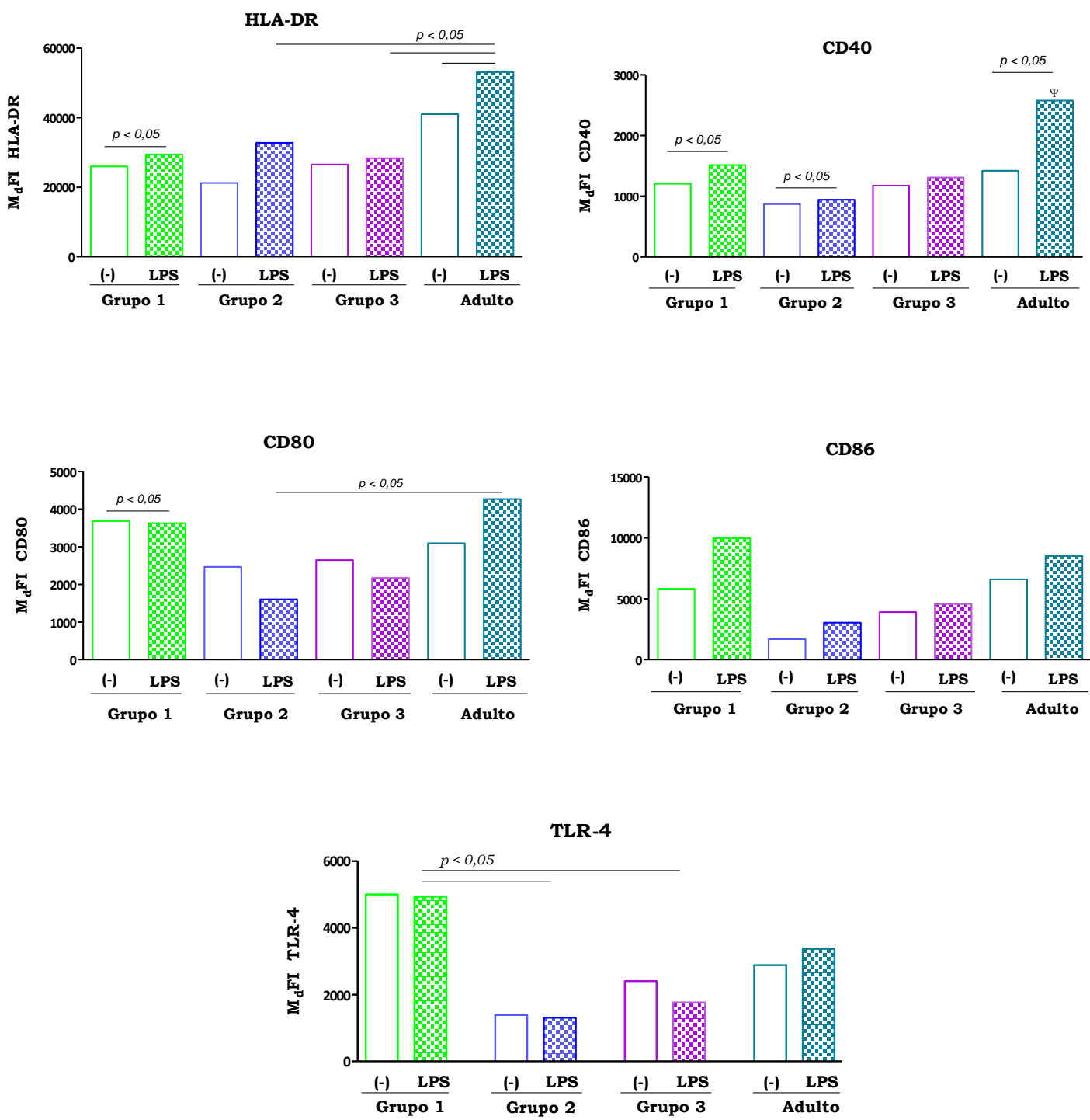

Figura 8. Análise da mediana da intensidade de fluorescência (MFI) da expressão dos marcadores HLA-DR, CD40, CD80, CD86 e TLR-4 das culturas de monócitos dos RN dos Grupos 1, 2 e 3 e de adultos ativados (LPS) e não ativados (-) com LPS 055 por 18 horas. Os gráficos representam a mediana dos valores de cada grupo. $\psi$ : valor significativamente maior dos monócitos estimulados do adulto quando comparados aos monócitos estimulados dos RN $(p<0,05)$.

A análise do marcador de expressão de CD80 em adultos após o estímulo foi significativamente maior quando comparado aos RN do Grupo 2, sendo que o Grupo 1 apresentou uma alta expressão de CD80 quando comparado aos outros grupos de RN, porém não foi estatisticamente significativa. A expressão da molécula coestimuladora CD86 foi semelhante entre amostras pré e pós-estímulo e entre os diferentes grupos. 
A expressão de HLA-DR nos adultos foi maior quando comparado aos RN dos Grupos 2 e 3, sendo que somente o Grupo 1 e adultos apresentaram diferenças estatísticas significativas entre amostras pré e pós- estímulo.

Quanto à expressão de CD40, todos os grupos apresentaram aumento estatisticamente significativo após o estímulo, com exceção dos RN do Grupo 3, porém a expressão foi significativamente menor em todos os RN após o estímulo quando comparados aos adultos. Com relação a molécula TLR-4, foi observada uma alta expressão apenas nos monócitos dos RN do Grupo 1 quando comparados aos Grupos 2 e 3 e com os adultos.

As mesmas culturas de monócitos foram avaliadas quanto à produção de citocinas no sobrenadante mediante estímulo com LPS. As citocinas próinflamatórias dosadas foram TNF- $\alpha$, IL-1 $\beta$, IL-6, IL-8, além da citocina antiinflamatória IL-10 (Figura 9).

Os monócitos neonatais apresentaram uma tendência à produção de níveis mais altos das citocinas pró-inflamatórias IL-6, TNF- $\alpha$ e IL-1 $\beta$ quando comparados aos adultos, porém estatisticamente não significativos. As dosagens das citocinas IL-6 e TNF- $\alpha$ revelaram diferenças significativas entre pré- e pós-estímulo para todos os grupos, com exceção do Grupo 1. Com relação a IL-8 e IL-1 $\beta$, todos os grupos apresentaram altos níveis de produção, no entanto, apenas o Grupo 3 e adultos mostraram diferença significativa entre pré- e pós-estímulo para IL-8 e apenas os adultos para IL$1 \beta$, embora tenham apresentado níveis menores, porém não estatisticamente significativos, quando comparados aos RN. 

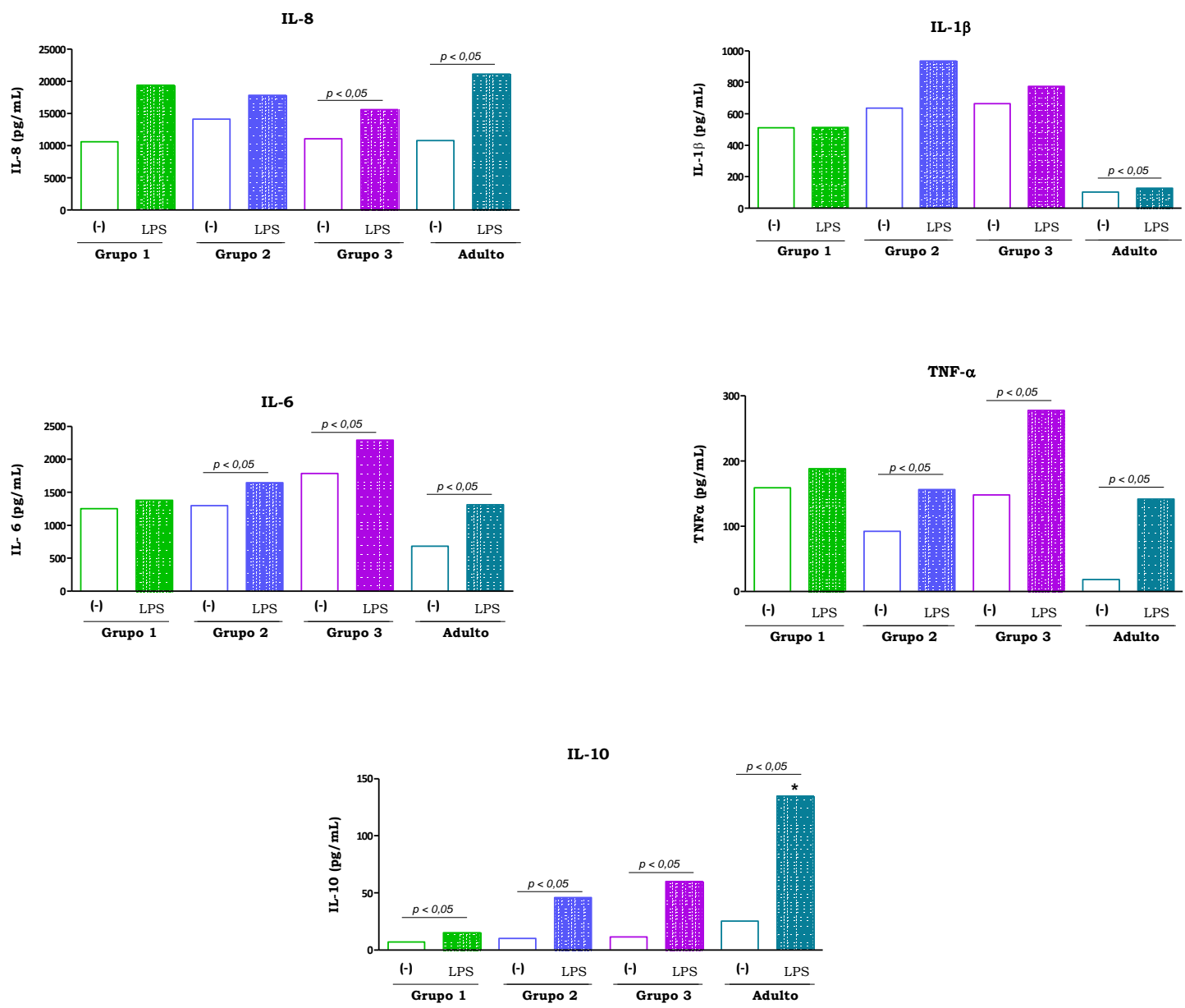

Figura 9. Concentrações das citocinas IL-8, IL-1 $\beta$, IL-6, TNF- $\alpha$ e IL-10 nos sobrenadantes das culturas de monócitos dos RN dos Grupos 1,2 e 3 e de adultos ativados e não ativados com LPS O55 por 18 horas. LPS: monócitos estimulados com $10 \mathrm{ng} / \mathrm{mL}$ de LPS O55; (-): monócitos não estimulados. Os gráficos representam a média dos valores de cada grupo. *: valor significativamente maior dos monócitos estimulados do adulto quando comparados aos monócitos estimulados dos RN $(p<0,05)$.

No que diz respeito à produção de IL-10, monócitos neonatais e de adultos responderam bem ao estímulo com diferenças significativas entre monócitos pré e pós-estimulados para todos os grupos. Embora tenham respondido ao estímulo, os monócitos dos RN apresentaram produção marcadamente reduzida pós-estímulo quando comparados aos adultos. 


\subsection{Análise da função fagocitica e burst oxidativo pelo método de DHR}

Antes de realizarmos as análises, confirmamos a marcação da bactéria por citometria de fluxo, como mostra a Figura 10, com imagens obtidas por microscopia confocal. Uma vez confirmada a eficácia da marcação, iniciamos a avaliação da atividade fagocítica e do burst oxidativo nos monócitos e neutrófilos do sangue de cordão umbilical dos RN.

A)

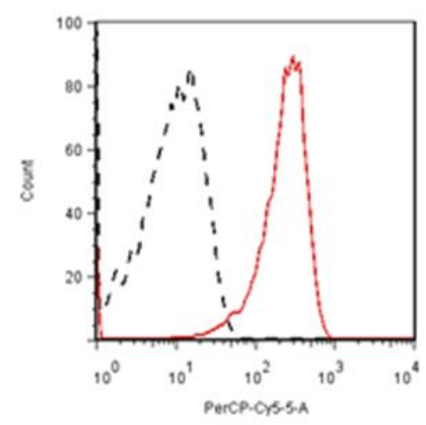

B)

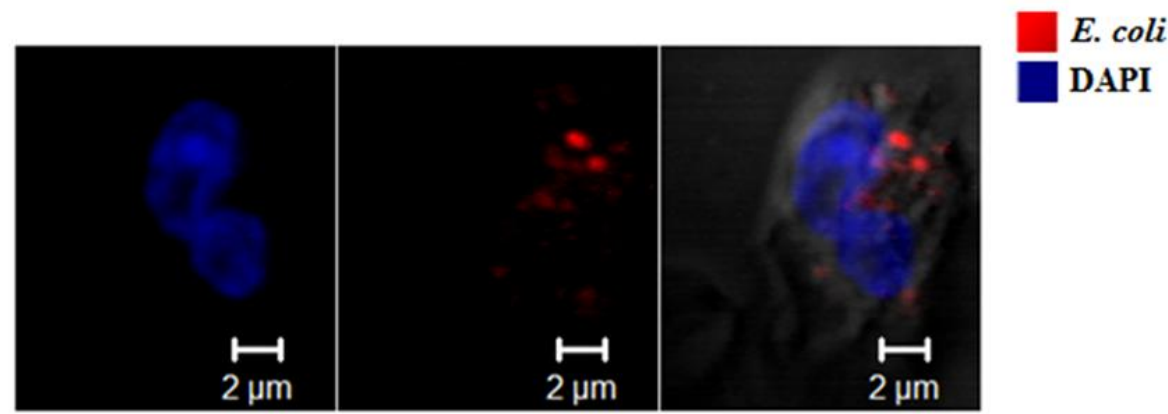

Figura 10. Marcação de E. coli para realização do teste de fagocitose. A) Histograma demonstrando a eficiência de marcação das bactérias. B) Imagens obtidas por microscopia confocal demonstrando a presença de $E$. coli no interior do fagócito. Os núcleos dos fagócitos foram marcados em azul com fluorocromo DAPI (4-6-diamidino-2-fenilindol) e as bactérias em vermelho com iodeto de propídio.

O ensaio de DHR foi realizado utilizando (8) amostras do Grupo 1, (12) do Grupo 2 e (23) amostras do Grupo 3, as quais foram acompanhadas por 24 amostras de sangue periférico de adultos saudáveis. 


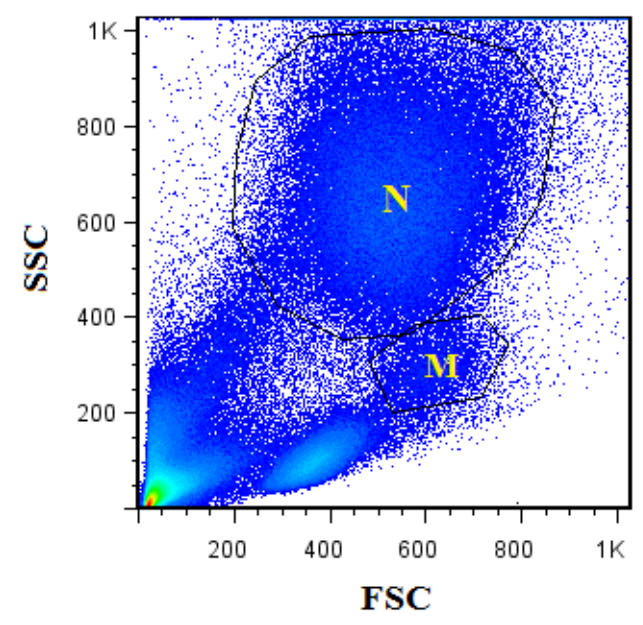

Figura 11. Dot plots representativos dos gates nas populações de neutrófilos (N) e monócitos (M) tendo como parâmetro o tamanho (forward scatter, FSC) e granulosidade celular (side scatter, SSC) para análise da atividade fagocítica e produção de $\mathrm{H}_{2} \mathrm{O}_{2}$.

As populações de monócitos e neutrófilos foram delimitadas utilizando como parâmetro o tamanho (FSC) e granulosidade celular (SSC), como mostra a Figura 11, acima.

Os resultados do índice de fagocitose de $E$. coli por monócitos e neutrófilos foram determinados pela porcentagem, que indica a quantidade de células com capacidade fagocítica e pela Média da Intensidade de Fluorescência (MFI) obtida nas análises, que corresponde ao número de bactérias que cada célula fagocítica internalizou.

Observa-se, na Figura 12, que os monócitos neonatais apresentam um aumento discreto da capacidade fagocítica de E. coli de acordo com a idade gestacional, mas monócitos de adultos são significativamente mais eficientes neste processo. O mesmo é visto para o MFI, onde a quantidade de bactérias fagocitadas aumenta gradativamente de acordo com a idade gestacional, e os adultos apresentam indice de fagocitose (MFI) e frequência estatisticamente maior que todos os grupos de RN. 


\section{$\mathbf{A}$}

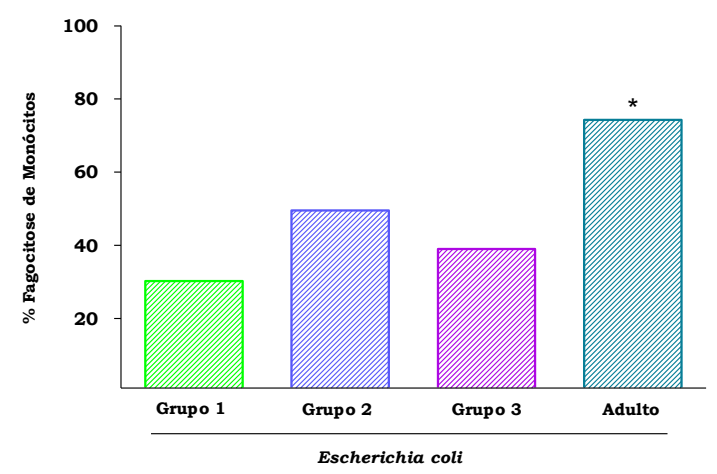

\section{B}

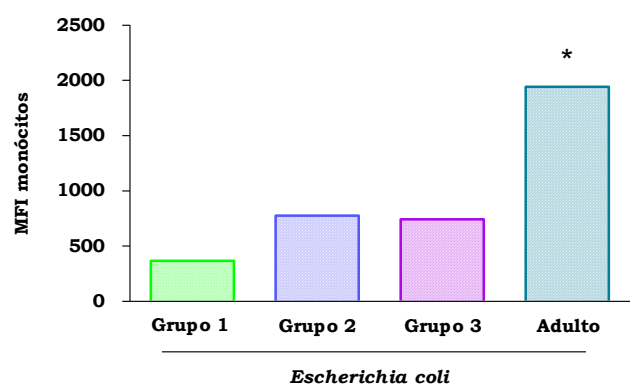

Figura 12. Fagocitose de E. coli por monócitos dos RN dos Grupos 1,2 e 3 e de adultos. (A) Porcentagem de fagocitose por monócitos e (B) índice de fagocitose representado pelo MFI. *: diferença estatística do adulto quando comparado aos grupos de $\mathrm{RN}(p<0,05)$. Os dados estão representados pela mediana dos valores.

A população de neutrófilos neonatais foi analisada quanto à sua capacidade fagocítica, apresentando-se reduzida em relação a dos adultos (Figura 13). Os resultados também demonstram que neutrófilos possuem um índice de fagocitose (MFI) estatisticamente maior do adulto quando comparado aos grupos de RN.
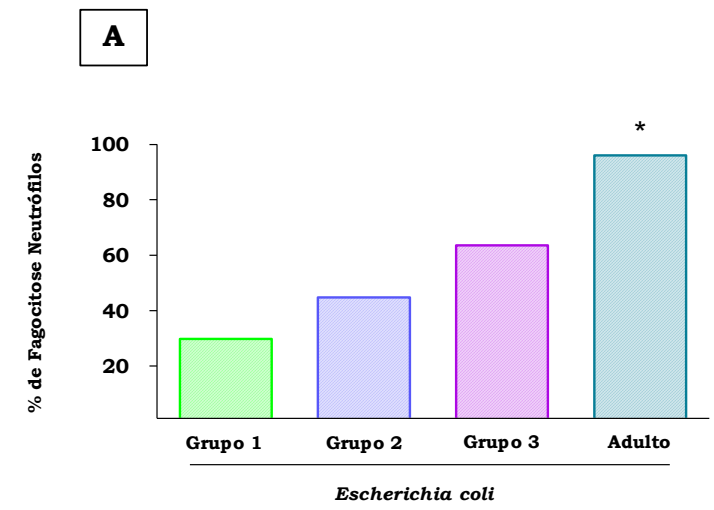

\section{B}

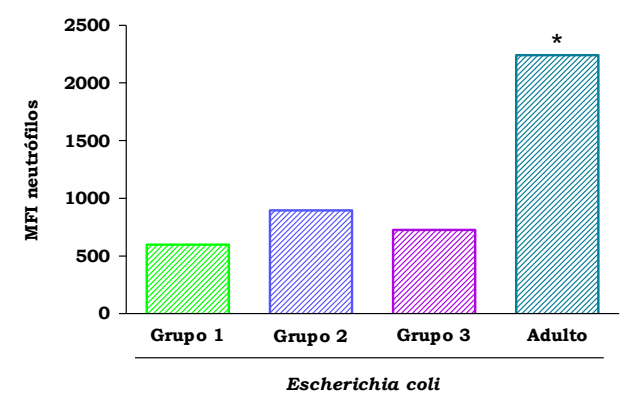

Figura 13. Fagocitose de E. coli por neutrófilos dos RN dos Grupos 1,2 e 3 e de adultos. (A) Porcentagem de fagocitose por neutrófilos e (B) índice de fagocitose representado pelo MFI. *: diferença estatística do adulto quando comparado aos grupos de $\mathrm{RN}(p<0,05)$. Os dados estão representados pela mediana dos valores. 
A seguir, na Figura 14, estão apresentados os resultados da análise da produção de peróxido de hidrogênio após estimulação dos fagócitos com PMA e após a fagocitose de $E$. coli. Os dados apresentados pela porcentagem representam os fagócitos produtores de $\mathrm{H}_{2} \mathrm{O}_{2}$ e o MFI representa a quantidade produzida destas moléculas.

Os resultados demonstraram que RN são capazes de gerar burst oxidativo após a fagocitose de E. coli, no entanto a resposta ao PMA mostrou maior porcentagem de monócitos produtores de peróxido de hidrogênio, constituindo o controle positivo do teste.

A porcentagem dos monócitos produtores de $\mathrm{H}_{2} \mathrm{O}_{2}$ foi reduzida no Grupo 2 em relação ao Grupo 3 e aos adultos quando estimulados com PMA e somente em relação aos adultos após fagocitose de E. coli. Quanto à análise do MFI, foi observada uma menor produção de $\mathrm{H}_{2} \mathrm{O}_{2}$ pelo Grupo 1 quando comparado ao Grupo 3 e ao Adulto, apresentando valores significativamente menores após ativação com PMA e após a fagocitose de $E$. coli. 
$\mathbf{A}$

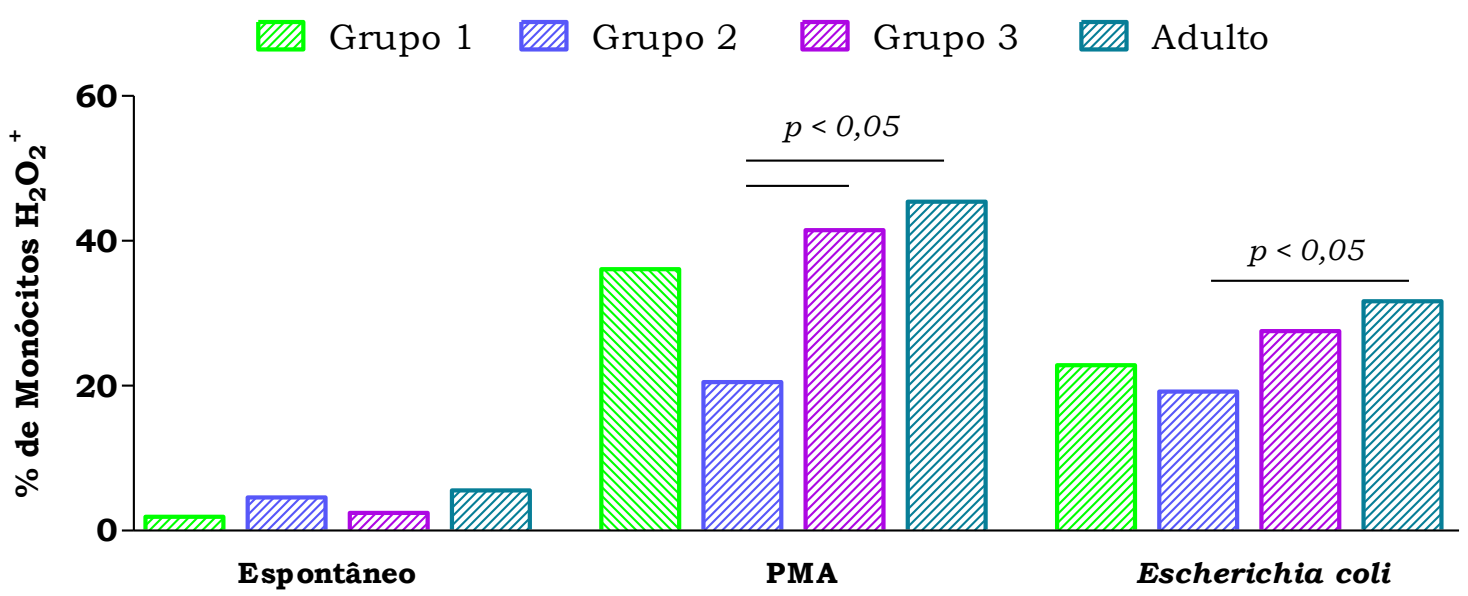

B

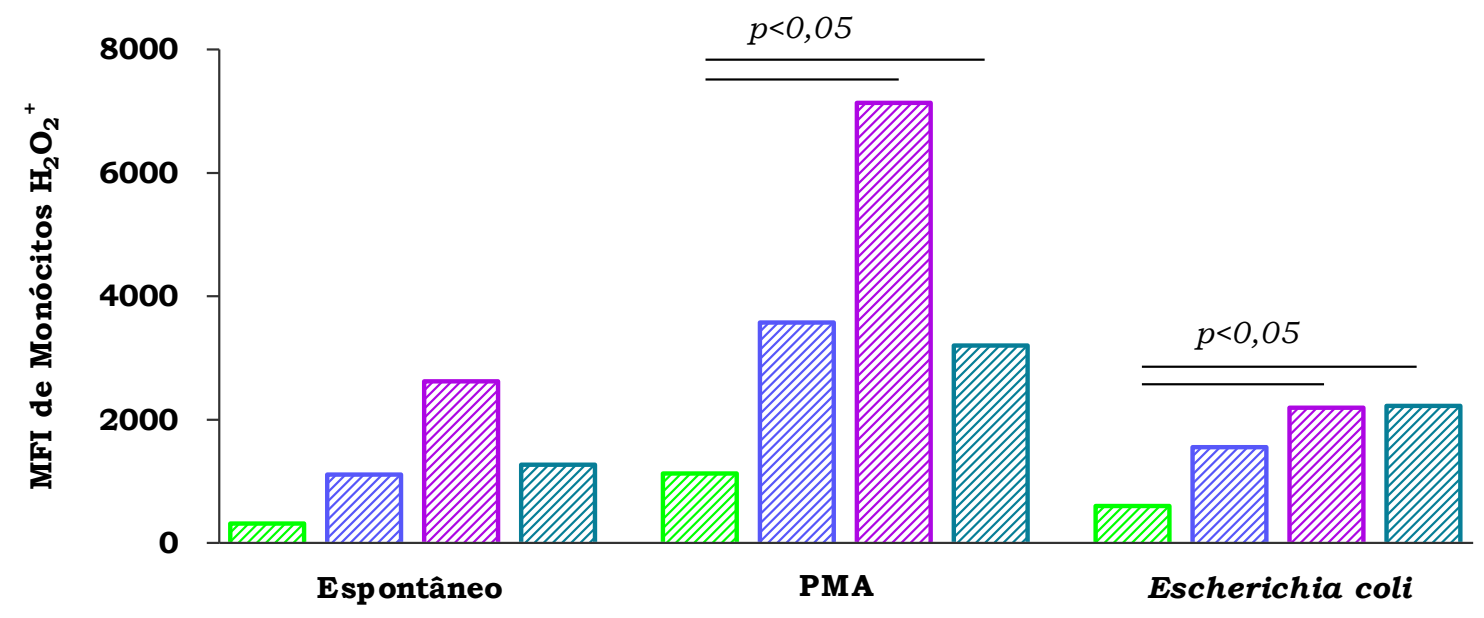

Figura 14. Avaliação do burst oxidativo de monócitos dos RN dos Grupos 1,2 e 3 e de adultos mediante estimulação com PMA ou após fagocitose de E. coli. As barras representam as porcentagens (A) e o MFI (B) de células produtoras de $\mathrm{H}_{2} \mathrm{O}_{2}$. Os dados estão representados pela média dos valores.

Na Figura 15, abaixo, observou-se que neutrófilos de todos os grupos foram capazes de gerar burst oxidativo, com produção de $\mathrm{H}_{2} \mathrm{O}_{2}$ após estímulo com PMA, no entanto, observamos uma frequência significativamente maior de neutrófilos produtores de $\mathrm{H}_{2} \mathrm{O}_{2}$ nos adultos quando comparada a dos RN. 
Após a fagocitose de E. coli, observou-se porcentagem significativamente reduzida de neutrófilos produtores de $\mathrm{H}_{2} \mathrm{O}_{2}$ no Grupo 2 em relação aos adultos. Quanto à análise do MFI, foram observadas diferenças estatísticas na produção de $\mathrm{H}_{2} \mathrm{O}_{2}$ pelos neutrófilos, onde os adultos apresentaram uma produção significativamente maior quando comparados aos Grupos de RN 1 e 2.
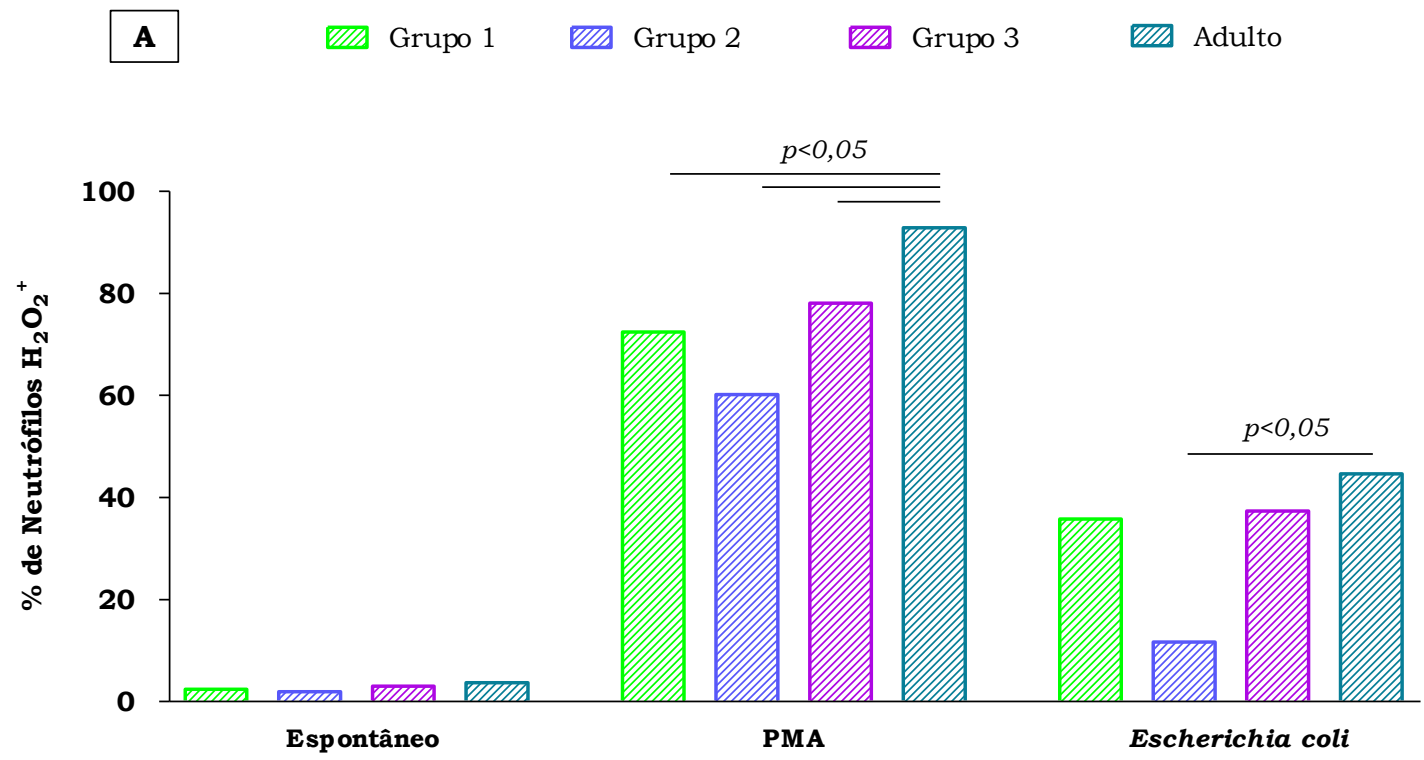

\section{B}

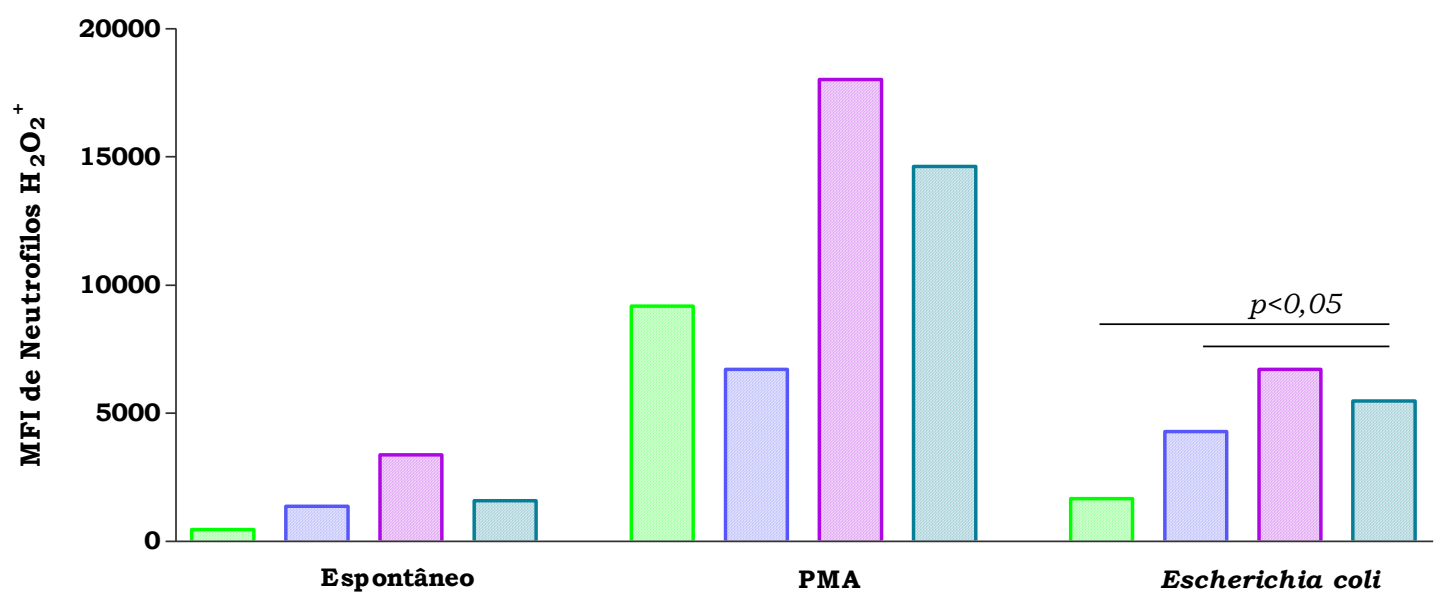

Figura 15. Avaliação do burst oxidativo de neutrófilos dos RN dos Grupos 1, 2 e 3 e de adultos mediante estimulação com PMA ou após fagocitose de E. coli. As barras representam as porcentagens (A) e o MFI (B) de células produtoras de $\mathrm{H}_{2} \mathrm{O}_{2}$. Os dados estão representados pela média dos valores. 


\subsection{Análise das moléculas da via de sinalização intracelular de TLR-4 em monócitos por citometria de fluxo}

Esta técnica foi realizada com (6) amostras do Grupo 1, (6) do Grupo 2, (12) do Grupo 3 e (12) amostras de adultos.

Os resultados das análises das moléculas fosforiladas (ativadas) ERK$1 / 2, \mathrm{NF}-\kappa \mathrm{B}, \mathrm{p} 38$ e IRAK-4 estão representados pela média da intensidade de florescência (MFI), como mostra a Figura 16.
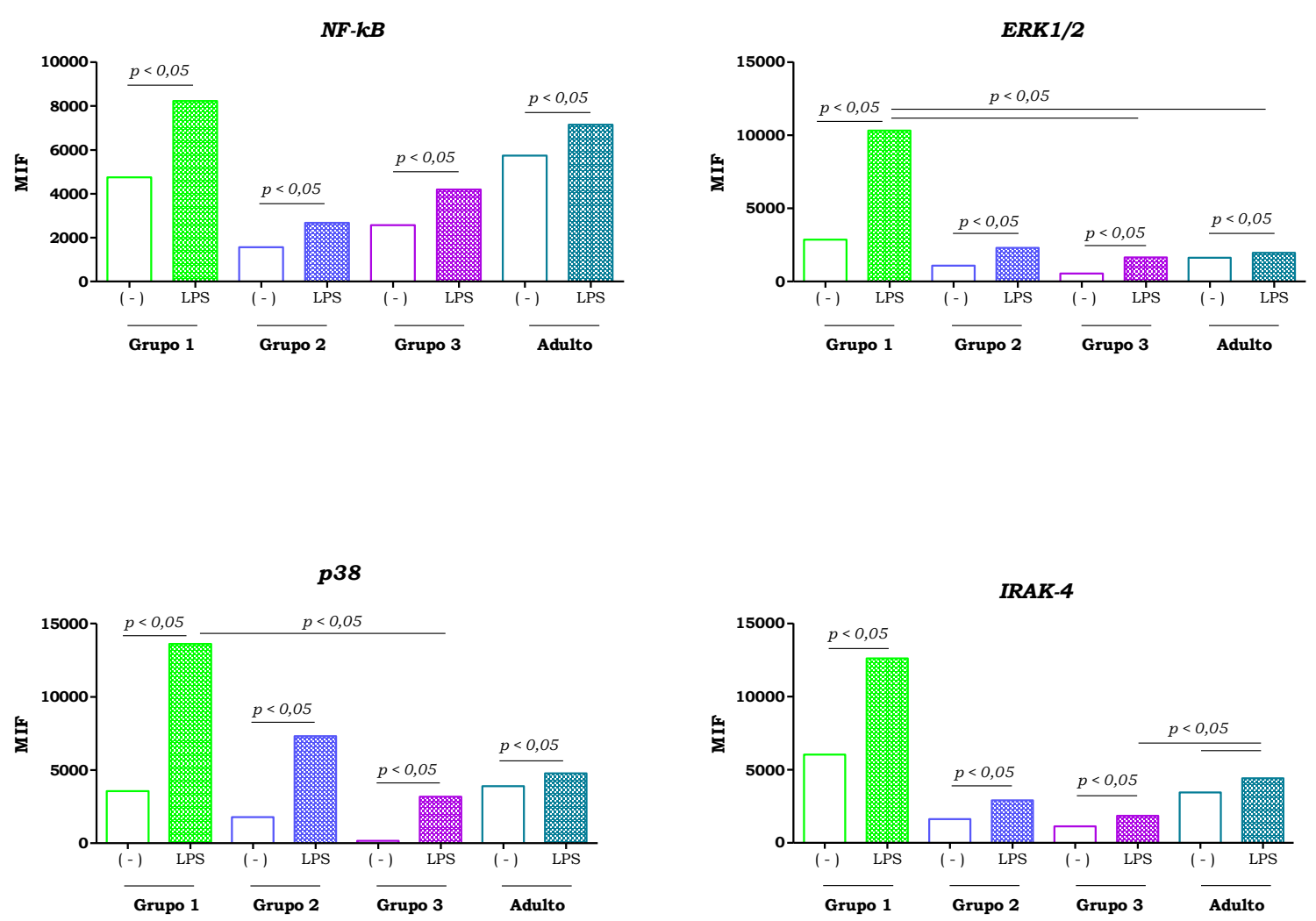

Figura 16. Análise da média da intensidade de fluorescência (MFI) da expressão das proteínas NF- $\kappa$ B, ERK-1/2, p38 e IRAK-4 ativadas (fosforiladas) em cultura de monócitos CD14+HLA-DR+ dos RN dos Grupos 1, 2 e 3 e de adultos não ativados (-) e ativados com LPS O55. Os gráficos representam a mediana dos valores de cada grupo.

Os resultados mostraram que os monócitos estimulados com o LPS O55 apresentam um aumento do MFI, variando esta intensidade para cada grupo e molécula analisada. 
Com relação à expressão do fator de transcrição $\mathrm{NF}-\kappa \mathrm{B}$, foi observada diferença significativa em todos os grupos entre amostras pré-estímulo e pós-estímulo, porém nenhuma diferença estatística entre os grupos.

A expressão da molécula ERK-1/2 mostrou diferenças significativas entre os monócitos pré- e pós-estímulo em todos os grupos, bem como uma maior expressão dessa proteína após estímulo no Grupo 1 em relação ao Grupo 3 e aos adultos.

A expressão da molécula p38 também apresentou diferenças significativas entre monócitos pré- e pós-estímulo em todos os grupos do estudo. Apenas o Grupo 1 revelou uma maior expressão desta proteína após estímulo quando comparado ao Grupo 3.

A expressão da molécula IRAK-4 apresentou diferenças significativas entre monócitos pré- e pós-estímulo em todos os grupos do estudo. Apenas o Grupo 3 revelou uma menor expressão desta proteína após estímulo quando comparado aos adultos. 
As situações pelas quais passam os RN pré-termo são adversas em relação às dos RN a termo em virtude do tempo de duração da gestação, estado de maturidade imunológica, entre outras condições fisiológicas pertinentes ao desenvolvimento, as quais aumentam as possibilidades de infecção, podendo levar à sepse neonatal (Melville, Moss, 2013).

Considerando estas condições peculiares da prematuridade, o foco desta pesquisa envolveu a avaliação da imunidade inata e dos seus mecanismos de ativação via TLR-4 na população de monócitos de dois grupos de RN pré-termo: Grupo 1 - pré-termo moderado e Grupo 2 - prétermo tardio, comparados aos RN do Grupo 3 - nascidos a termo e aos adultos buscando, desta forma, conhecer mais intimamente as particularidades da imunidade inata, especialmente do grupo de RN prétermo, o qual ainda necessita de um maior conhecimento nesse âmbito.

Os objetivos traçados na pesquisa focaram um número amostral expressivo para cada grupo estudado, desta forma é de extrema importância algumas considerações no tocante aos obstáculos encontrados a este respeito. Dentre as limitações encontradas para o estudo temos: o volume de sangue escasso para a realização dos experimentos propostos; raridade do material; os critérios de exclusão rigorosos e; por fim, o material proveniente de um hospital público terciário com gestantes predominantemente portadoras de diversas enfermidades e de relevante gravidade, em grande parte, de etiologia infecciosa. Estes obstáculos, isoladamente ou em conjunto, conduziram a um número amostral aquém do planejado em alguns dos grupos de $\mathrm{RN}$, sendo importante expor que algumas amostras coletadas não obedeceram aos critérios de inclusão da pesquisa, sendo descartadas após realização da dosagem de citocinas séricas ou após análise dos exames laboratoriais, quando havia suspeita de infecção.

Os partos prematuros, em sua maioria, são caracterizados pela presença de infecção vertical adquirida ao nascimento ou corioamnionite, fatores complicadores para obtenção de amostras isentas de patógenos, o que levou a um número reduzido de amostras de RN do Grupo 1. Este grupo, devido às suas peculiaridades, apresentou inúmeros casos com 
placenta de tamanho reduzido que, no momento da dequitação, fragmentase, impossibilitando a coleta (Krediet et al., 2007).

Anteriormente a realização dos experimentos para avaliação da ativação dos monócitos via TLR-4 foi realizada a análise de citocinas séricas do soro de cordão umbilical dos $\mathrm{RN}$ e, assim, foram selecionadas as amostras sem indícios de infecção.

As análises das citocinas pró- e anti-inflamatórias obtidas das amostras de soro de cordão apresentaram valores considerados normais para todos os RN incluídos em nossa casuística (Prokesová et al., 2006; Rizos et al., 2005; Santana et al., 2001).

Em estudo realizado por Protonotariou et al. (1999) não foram constatadas diferenças nos níveis de citocinas IL-1 $\beta$ e IL-6 entre amostras de soro de cordão umbilical dos RN e de soro do sangue periférico de adultos. Quanto aos niveis de TNF- $\alpha$, houve um aumento até o $5^{\circ}$ dia após o nascimento e uma posterior redução, até o $44^{\circ}$ dia. Dados divergentes foram apresentados por Rizos et al. (2005), que analisaram as mesmas citocinas citadas anteriormente, as quais apresentaram niveis mais elevados no soro de cordão quando comparado ao soro de adultos. Os autores também apuraram através de análises das mesmas amostras os níveis das citocinas relacionadas com o tipo de parto realizado, parto vaginal ou cesárea, onde foram encontrados niveis mais elevados de citocinas no parto normal em relação ao parto cesárea. Considerando as reflexões de Vrachnis et al. (2010), à respeito das dificuldades presentes no estudo do sistema imunológico inato de RN humanos, deve-se considerar que estas dificuldades decorrem também do fato de que a liberação de citocinas e mediadores inflamatórios pode ocorrer em outras situações não patológicas, como a gravidez e o parto, e não apenas em infecções.

Mediante estas constatações da literatura sobre a relação de determinadas citocinas com o tipo de parto, foi realizada a análise comparativa dos níveis de citocinas nas amostras de sangue de cordão umbilical dos RN do presente trabalho agrupados por tipo de parto. Os resultados obtidos das concentrações das citocinas pró-inflamatórias IL-6, IL-8 e IL-1 $\beta$ apresentaram conformidade com os estudos acima citados, com 
exceção dos niveis de TNF- $\alpha$ que, embora estivessem mais altos no parto vaginal, não apresentaram diferença significativa.

A relação estabelecida entre os niveis de citocinas inflamatórias com tipo de parto mostrou que o parto a termo está fortemente ligado a estimulação de uma rede de citocinas. Esta ligação está refletida diretamente nos altos níveis encontrados no soro materno e no soro de cordão umbilical durante o parto, bem como nas amostras neonatais durante os primeiros dias de vida. Esses resultados reforçam a sugestão de que o próprio parto a termo, sendo um processo inflamatório, promoveria a ativação da resposta imune neonatal, ocasionando um aumento significativo de citocinas próinflamatórias durante os primeiros dias de vida. Reforçando ainda esta ideia, Rizos et al. (2005) constataram a presença dos receptores solúveis de citocinas, sIL-6R, sTNFRI e sTNFRII, em concentrações elevadas nas amostras neonatais, o que denota um mecanismo regulatório de proteção para a mãe e neonato contra a função sistêmica das citocinas, durante o trabalho de parto e na vida neonatal precoce.

A análise dos níveis de citocinas no período neonatal precoce é ferramenta importante de identificação de sepse. Os RN com muito baixo peso ao nascimento e com suspeita de sepse, apresentam níveis plasmáticos das citocinas IL-10 (>208 pg/ml), IL-6 (>168 pg/ml) e RANTES (regulated upon activation normal T-cell expressed and secreted) (>3110 pg/ml) com sensibilidade e especificidade de 100 e 97\%, respectivamente sendo, assim, utilizados na identificação de pacientes infectados que posteriormente desenvolvam coagulação vascular disseminada. Os marcadores IP10/CXCL10, MIG/CXCL9, IL-6 e IL-10 relatados em outros estudos, alcançaram sensibilidade e especificidade de mais de $80 \%$ e $75 \%$, respectivamente, para a detecção de sepse. Devido ao rápido declíneo desses marcadores inflamatórios após o início da sepse, as dosagens realizadas em 24 horas apresentaram valores preditivos menores do que aqueles feitos no momento do diagnóstico (Arnon, Litmanovitz, 2008; Ng et al., 2007).

Embora um estudo de Bonac et al. (2000) tenha demonstrado que a IL-8 não é uma ferramenta útil para o diagnóstico de infecção, a maioria dos 
estudos encontrou a concentração desta citocina consideravelmente aumentada em neonatos infectados (Meem et al., 2011).

Em trabalho realizado por Dollener et al. (2001) foi visto que a proteina $\mathrm{C}$ reativa (PCR) teve melhor desempenho como um teste diagnóstico de sepse neonatal e a precisão deste diagnóstico foi ainda melhorada pela combinação da dosagem da PCR com a de IL-6.

A sepse é uma condição mediada essencialmente por citocinas e é desencadeada pela presença de um patógeno, na qual a homeostase imunológica, inflamatória e de coagulação é perturbada. A evolução dos sintomas clínicos da sepse depende do balanço delicado entre fatores pró e anti-inflamatórios. As citocinas pró-inflamatórias (TNF-a, IL-1 $\beta$, IL-6, IL-8, IL-15, IL-18, MIF), os fatores de crescimento (IL-3, CSFs), e seus mediadores secundários, incluindo óxido nítrico, tromboxanos, leucotrienos, prostaglandinas, fator ativador de plaquetas e complemento causam a ativação das cascatas de coagulação, complemento e produção de prostaglandinas, leucotrienos, proteases e oxidantes. Caso estes mediadores não sejam contrabalanceados pela síntese adequada de diversas substâncias, como as citocinas anti-inflamatórias IL-10 e TGF- $\beta 2$, receptor solúvel de TNF (TNFsr), antagonista do receptor de IL-1 (IL-1Ra) e receptor de IL-1 do tipo II (IL-1RII), estes mesmos mediadores inflamatórios estarão estritamente associados a complicações em curto e longo prazo na sepse neonatal (Chirico, Loda, 2011).

Alguns estudos como de Kalinski et al. (2000) e Széles et al. (2009) indicam que diferenças na fração solúvel do sangue podem desempenhar um papel crucial na polarização do sistema imune neonatal contra respostas do perfil TH1. O CD14 solúvel (CD14s) é também um constituinte do plasma humano que modula a atividade do LPS na célula hospedeira. O CD14 é encontrado em sua forma solúvel e na superficie de monócitos e macrófagos, e tem seu nivel aumentado no soro de pacientes com sinais clínicos de septicemia por bactérias Gram-negativas, exercendo a função de um receptor solúvel para o complexo LPS/proteína ligante de LPS. Existem evidências que o CD14s é expresso em baixos níveis ao nascimento atingindo, aos dois anos de idade, níveis semelhantes aos de adultos, 
levantando a possibilidade de que diferenças em seu conteúdo plasmático entre RN e adultos podem contribuir para uma menor ativação de TLR em neonatos (Holmlund et al., 2003; Levy et al., 2004). No presente trabalho, foram observadas concentrações crescentes de CD14s em função do aumento da idade gestacional ao nascimento, o que poderia implicar em uma menor ativação de TLR-4 nos RN pré-termo.

No entanto, Levy et al. (2004) demonstrou que, embora os niveis de CD14s no plasma de RN sejam apenas 40\% dos de adultos, estas diferenças na concentração de CD14s não foram responsáveis pelos efeitos divergentes do plasma de RN e adultos na liberação de TNF-a induzida por ligantes de TLR.

Em trabalho mais recente, sugeriu-se que o aumento da concentração de LBP (proteína ligante de LPS) e CD14s no plasma neonatal poderia ser responsável pelo aumento da produção de IL-10 após ativação de TLR-4. Entretanto, os niveis de LBP foram semelhantes entre amostras de plasma de cordão umbilical de RN de um mês e de adultos, e as concentrações de CD14s foram inferiores no plasma de cordão umbilical em relação aos adultos, sugerindo a participação de outros fatores do plasma como responsáveis por essa resposta (Belderbos et al., 2012).

Após a avaliação dos níveis de citocinas presentes no soro de cordão umbilical e sua relação com os tipos de parto foi realizada a imunofenotipagem dos leucócitos do sangue de cordão umbilical. O objetivo desta caracterização foi avaliar quantitativamente e qualitativamente a presença das APC, bem como dos linfócitos T e B envolvidos na resposta a bactérias extracelulares.

A caracterização imunofenotípica dos leucócitos do sangue de cordão umbilical mostrou um maior número de leucócitos presentes no grupo de RN nascidos a termo quando comparados aos outros grupos de RN e aos adultos, o que já foi bem estabelecido em análises realizadas dos números de leucócitos em RN de diferentes idades gestacionais (Milcic, 2010). No que diz respeito às células mieloides e linfoides no sangue periférico de um RN saudável a termo, as proporções de ambas são geralmente mais elevadas do 
que no RN pré-termo (Berrington et al., 2005; Christensen et al., 2009; Sharma et al., 2012).

Para lidar com uma variedade de agentes patogênicos e para simultaneamente evitar reações patológicas aos antígenos próprios é crucial a indução dos diferentes tipos de respostas imune inata e adaptativa baseadas na natureza dos antígenos e no contexto do microambiente. Desta forma as células dendriticas (DC) destacam-se com seu importante papel como potentes APC, o que já está bem estabelecido na literatura, desempenhando um papel único na ativação, polarização e regulação da resposta imune adaptativa (Ito et al., 2005; Kadowaki, 2009; Sorg et al., 1999; Velilla et al., 2006).

Velilla et al. (2006) mostram que 0,3\% das células mononucleares do sangue de cordão umbilical são DCs. Dependendo de sua origem, ativação por citocinas, antígenos de superfície e capacidade funcional, as DC podem ser subdivididas em duas grandes populações distintas: DC mieloides (mDC) e DC linfoides/ plasmocitoides (pDC) (Adams et al., 2005).

As DC mieloides são consideradas boas estimuladoras de células T CD4 naive e secretam TNF- $\alpha$, IL-8, IL-10, altos niveis de IL-12, e uma pequena quantidade de IL-23 pode ser detectada após o uso de uma gama de estimulos. Isto implica em um duplo papel na indução de respostas do tipo $\mathrm{T}_{\mathrm{H}} 1$ e $\mathrm{T}_{\mathrm{H}} 17$, destacando a plasticidade das $\mathrm{DC}$ em diferentes contextos. DC plasmocitoides são diferenciadas pela expressão de CD123, CD303 e CD304 e possuem propensão para liberar grandes quantidades de IFN do tipo I em resposta a vírus, sendo uma das primeiras funções das DC a serem descritas. Foi demonstrado que pDC isoladas do sangue não ativam células $\mathrm{T}$ naive de forma eficiente e aparecem menos maduras do que $\mathrm{mDC}$ até serem ativadas, em concordância com os nossos resultados onde a frequência de $\mathrm{pDC}$ imaturas $\left(\mathrm{CD} \mathrm{a}^{+}\right)$foi maior que a de $\mathrm{mDC}$. No entanto, sem diferenças estatísticas entre os grupos de RN. É importante considerar que a capacidade das pDC de polarizar respostas de células T CD4 para o perfil $\mathrm{T}_{\mathrm{H}} 1$ ou $\mathrm{T}_{\mathrm{H}} 2$ é variável e pode ser dependente do contexto onde a mesma está inserida (Adams et al., 2005; Collin et al., 2013). 
Os números absolutos e relativos observados de DC totais foram significativamente mais elevados nos grupos de RN quando comparados aos adultos. Porém os adultos apresentaram uma maior frequência de mDC quando comparados aos $\mathrm{RN}$, o que nos sugere uma possivel contribuição para uma ativação mais eficiente da resposta de células T nos adultos.

Quando analisada a expressão da molécula TLR-4, observou-se uma baixa expressão em todas as APC, porém uma frequência significativamente maior de mDC TLR-4+ em adultos quando comparados aos grupos de RN, sendo que as pDC TLR-4+ não apresentaram diferenças estatisticamente significativas entre os grupos, porém uma tendência a uma menor expressão nos RN. Contrariamente a estes resultados, os dados da literatura de Drohan et al. (2004) e Gulubova et al. (2012) mostram o nivel de expressão de TLR-4 normal em mDC de RN, contrastando com o baixo nível de expressão desta molécula em monócitos destes mesmos RN. Com relação aos monócitos neonatais, os nossos resultados não mostraram diferenças significativas na expressão de TLR-4 entre os diferentes grupos de RN e adultos, embora tenha encontrado uma reduzida expressão dessa molécula em todos os grupos. A expressão reduzida de TLR-4 em mDC neonatais encontrada em nosso trabalho juntamente com a regulação de moléculas importantes envolvidas na sinalização de TLR, as quais ainda não foram avaliadas em DC neonatais, poderia explicar a relativa falta de resposta de DC neonatais à estimulação de TLR por bacilos Gram-negativos (Velilla et al., 2006).

Descrevendo ainda as populações celulares destes $\mathrm{RN}$, foram encontrados números mais elevados de monócitos em RN quando comparados aos adultos, sendo que o Grupo 1 apresentou número inferior de monócitos quando comparado aos outros grupos. O estudo realizado por Velilla et al. (2006) descreveu a existência de diferenças qualitativas nos monócitos durante a vida intrauterina, onde a fenotipagem de monócitos circulantes neonatais ou fetais do terceiro trimestre de gestação revelam expressão reduzida da molécula de MHC de classe II (HLA-DR) e baixa expressão basal de CD86 e CD40, contribuindo potencialmente para uma atividade deficiente da APC. Em discordância, nosso trabalho mostra 
frequências semelhantes de monócitos expressando CD80 e CD86 entre os $\mathrm{RN}$ e adultos, porém as porcentagens de monócitos $\mathrm{CD}^{+} 0^{+}$foram ligeiramente inferiores nos grupos de $\mathrm{RN}$, embora significativamente diferente apenas para o Grupo 2. Também é importante salientar a redução da expressão de CD80 por mDC e pDC encontrada nos RN do Grupo 1, o que pode reforçar a idéia de uma atividade ineficiente das APC nos RN prematuros moderado.

Nos primeiros anos de vida, o número percentual e absoluto de linfócitos no sangue periférico é elevado, corroborando com os dados do nosso trabalho. Sendo assim, no primeiro ano de vida a linfocitopenia é considerada preocupante, caracterizada por números totais de linfócitos repetidamente inferiores a 2.500 células $/ \mathrm{mm}^{3}$, o que pode ser um indicativo de alerta para imunodeficiência grave (Heldrup et al., 1992). Considerando ainda as várias subpopulações de linfócitos, estas se assemelham aos adultos em todas as fases da vida, destacando uma predominância de células T CD4 (40-50\%), seguida das células T CD8 (15 - 25\%), considerando-se que as células T constituem entre 70 e $80 \%$ dos linfócitos circulantes.

Em nosso trabalho, foi constatada uma maior frequência de linfócitos totais nos grupos de RN prematuro em comparação com os nascidos a termo e adultos. No entanto, as porcentagens de linfócitos T CD4 foram equivalentes entre todos os grupos, com exceção dos RN a termo que apresentaram uma menor frequência dessa população e da subpopulação de linfócitos T CD4 naive quando comparados aos adultos. Estes resultados já foram apresentados por Peoples et al. (2009) e Pérez et al. (2007) sugerindo que, provavelmente, os RN com idade gestacional próxima ao termo, que estão prontos para deixar o ambiente protetor do útero, apresentam a necessidade de mobilizar um maior número de células para os linfonodos periféricos a fim de responder aos possiveis agentes infecciosos. Este fato também pode explicar as baixas frequências de $\mathrm{mDC}$ e $\mathrm{pDC}$ em RN a termo em comparação com os prematuros.

No decorrer dos primeiros anos de vida, segundo Heldrup et al. (1992), a proporção de células $\mathrm{T}$ naive é elevada, diminuindo gradativamente, 
concomitante ao aumento da porcentagem de células $\mathrm{T}$ de memória. As células de memória são originárias de células $\mathrm{T}$ efetoras que decorrem da ativação de células T naive. Estas mesmas células T naive são caracterizadas pela expressão de CD45RA, CCR7 e receptores coestimuladores CD27 e CD28. As células $\mathrm{T}$ efetoras expressam diversos marcadores, entre eles o CD69, CD25, com baixos niveis de CD62L. Em relação às células $\mathrm{T}$ de memória central, estas residem preferencialmente nos linfonodos, apresentando várias características fenotípicas em comum com as células $\mathrm{T}$ naive, com exceção da expressão de CD45RA. Células T de memória efetora migram preferencialmente para os tecidos periféricos e não expressam CD45RA ou CCR7 e, dependendo de seu estado de diferenciação, podem ou não expressar CD27 / CD28 (Tanel et al., 2009).

Em estudo desenvolvido por de Vries et al. (1999), a subpopulação de células $\mathrm{T}$ naive apresentou uma frequência relativamente alta nos RN em relação aos adultos, reforçando nossos dados que mostram maior frequência de linfócitos T naive nos grupos de RN quando comparados aos adultos, sem diferenças significativas entre os neonatos, embora os RN do Grupo 1 tenham apresentado frequência ligeiramente menor, porém não significativa, em relação aos outros. Este maior número de células T naive por nós encontrados já foi visto anteriormente na literatura, onde neonatos prematuros apresentam população de células $\mathrm{T}$ naive reduzida quando comparada a dos RN a termo (Peoples et al., 2009; Walker et al., 2011).

As outras subpopulações de células $\mathrm{T}$, as efetoras e de memória efetora, por sua vez, apresentaram maior frequência nos adultos em relação aos RN neste trabalho. Considerando-se que essas populações necessitam de uma ativação prévia por antígenos, é de se esperar frequências destas células mais altas em adultos. Linfócitos $\mathrm{T}$ de memória central apresentaram-se em frequências equivalentes entre os grupos. O estudo desenvolvido por Szabolcs et al. (2003) mostrou dados controversos aos do nosso trabalho, onde a frequência de células $\mathrm{T}$ de memória mostrou-se reduzida nos RN quando comparados aos adultos, embora estes autores não tenham realizado a diferenciação entre as subpopulações de células $\mathrm{T}$ de memória, central e efetora. 
Com relação às subpopulações de células $B$, estas se encontram em números significativamente mais elevados nos grupos de $\mathrm{RN}$ devido à linfocitose neonatal, citada anteriormente por de Vries et al. (1999), os quais relataram que células $\mathrm{B} \mathrm{CD}^{1} 9^{+}$foram mais frequentes no sangue de cordão em relação ao adulto. Mais tarde, Curtis et al. (2011) descreveu os mesmos dados.

A maioria dos linfócitos $\mathrm{B}$ consiste, principalmente, de células naive em RN a termo e prematuros, sendo aqui observadas, como nos trabalhos desenvolvidos por Walker et al. (2011) e van Gent et al. (2009), onde as frequências foram significativamente reduzidas de células $B$ de memória em neonatos, em comparação com adultos. O processo de ativação dos linfócitos $\mathrm{B}$ de memória e naive pode ocorrer através da ligação do CD40, receptor expresso constitutivamente nessas células, ao seu ligante CD154 (CD4OL) presente nos linfócitos T. Segundo Néron et al. (2011) a interação entre CD40-CD40L tem uma função central na formação do centro germinativo e no desenvolvimento da memória humoral, indução da proliferação, switch de classes de imunoglobulinas, diferenciação e secreção de citocinas e imunoglobulinas. Deste modo, os resultados do nosso trabalho demonstraram uma expressão consideravelmente baixa de CD40 em linfócitos B de RN do Grupo 1 quando comparados aos outros grupos de RN, porém sem diferença significativa, anunciando uma provável deficiência nos processos acima citados, os quais são de grande importância para a indução da imunidade adaptativa.

Quanto à presença de TLR-4 em células B, foi observada uma baixa expressão, porém nenhuma diferença estatística entre os grupos de RN, como também destes quando comparados aos adultos. Em estudo realizado por Kollmann et al. (2009) com população de neonatos foi constatada expressão basal de TLR com níveis equivalentes a do adulto, o que sustenta os nossos dados.

A caracterização e a quantificação das populações celulares presentes ao nascimento é muito importante, considerando-se que os números elevados destas populações não implicam em uma função adequada. Deste modo, feita a caracterização imunofenotípica dos leucócitos dos RN, este 
trabalho prosseguiu com a exploração dos aspectos funcionais da população de monócitos em cultura.

O destaque desta população está, entre outros, no seu papel crítico na regulação imune, na defesa contra organismos estranhos através da fagocitose, da produção de citocinas e da apresentação de antígenos para os linfócitos. A importância do monócito como APC se destaca classicamente no processo de apresentação de antígenos onde ocorre a "sinapse imunológica", com a interação dos linfócitos T naive levando a maturação da APC e a geração de linfócitos $\mathrm{T}$ efetores. Essa interação ocorre de forma antígenodependente, onde o HLA-DR apresenta fragmentos do antígeno para o receptor do linfócito $\mathrm{T}$ (10 sinal); interage com os linfócitos $\mathrm{T}$ por meio de suas moléculas coestimuladoras, CD40, CD80 e CD86 ( $2^{\circ}$ sinal); e libera mediadores solúveis ( $3^{\circ}$ sinal), como as citocinas (Fuji et al., 2004; Mescher et al., 2006).

Até o momento a literatura tem relatos de deficiência funcional na população de monócitos ao nascimento, especialmente em RN prematuros, entretanto o conhecimento sobre os mecanismos fisiopatológicos que explicam esse comprometimento funcional ainda é incipiente. Os resultados das culturas de monócitos do presente trabalho mostram uma menor expressão de HLA-DR nos grupos de RN quando comparados aos adultos. Estes resultados apresentaram concordância com os dados apresentados na literatura (Kanakoudi-Tsakalidu et al., 2001; Nguyen et al., 2010; Pérez et al., 2010). Todos os grupos de RN do presente trabalho apresentaram um aumento da expressão de HLA-DR após o estímulo antigênico, como esperado, porém não estatisticamente significativo, com exceção do Grupo 1, lembrando que a apresentação ocorre essencialmente na presença da molécula de HLA-DR que é expressa nestas células e reflete o seu estado de ativação. As discrepâncias estatísticas observadas no Grupo 1 podem ser decorrentes do menor número amostral utilizado nesse grupo em relação aos demais (Birle et al., 2003; Kanakoudi-Tsakalidou et al., 2001; Lekkou et al., 2004).

Diante do perfil de expressão mais reduzido da molécula HLA-DR nestes grupos de RN em relação aos adultos, pode-se inferir que, 
possivelmente, esta molécula importante na apresentação antigênica aliada a outros fatores próprios da imaturidade deste grupo neonatal, pode interferir na ativação da resposta imune celular. Isso se repete em relação à molécula coestimuladora CD40. Foi verificada uma expressão semelhante dessa molécula antes do estímulo, porém uma expressão significativamente mais baixa após o estímulo nos monócitos neonatais em relação aos adultos. A baixa expressão de CD40 em resposta ao estímulo poderia também contribuir para uma menor ativação de linfócitos T neonatais.

De acordo com Quezada et al. (2004) a interação CD40/CD40L é essencial para a geração de células $\mathrm{T}$ CD4 de memória do tipo $\mathrm{T}_{\mathrm{H}} 1$, de células B de memória e troca de isotipo de imunoglobulinas. Enquanto a expressão basal de CD40 em células B é descrita como normal, assim como observado no presente trabalho, segundo o trabalho realizado por Durandy et al. (1995), a expressão de CD40L por células T CD4 neonatais ativadas permanecem reduzidas por, pelo menos, 10 dias após o nascimento, mas se tornando semelhante às células adultas em 3 a 4 semanas. $\mathrm{Na}$ maioria destes estudos, células T CD4 de cordão umbilical ativadas expressaram quantidades marcadamente mais baixas da proteína de superfície e RNAm de CD40L do que ambas células T CD4 CD45RA hi ou CD45ROhi de adultos (Nonoyama et al., 1995). Tendo em vista a importância do CD40L em múltiplos aspectos da resposta imune, limitações na expressão do CD40L podem contribuir para a diminuição da imunidade antígeno-específica mediada por células $T_{\mathrm{H}} 1$ efetoras e por células $\mathrm{B}$ no neonato (Notarangelo et al., 2006).

Com relação às moléculas $\mathrm{CD} 80$ e CD86, não foram observadas mudanças significativas em seu nível de expressão em monócitos antes e após o estímulo, nem nos grupos de neonatos, nem nos adultos, embora tenha sido verificada um redução na expressão de CD80 após o estímulo em monócitos dos grupos de RN, significativa apenas para o Grupo 1.

Dados da literatura de Kuchroo et al. (1995) mostram em estudos com modelos experimentais realizados em ratos que o bloqueio da molécula CD80 melhora a encefalomielite autoimune, deslocando o fenótipo de resposta para um perfil $\mathrm{T}_{\mathrm{H}} 2$, enquanto que o bloqueio seletivo de CD86 piora a doença, 
cuja resposta passa a ser mediada por um perfil do tipo $\mathrm{T}_{\mathrm{H}} 1$, o que indica que as respostas $T_{H} 1$ requerem a coestimulação de CD80, enquanto as respostas $\mathrm{T}_{\mathrm{H}} 2$ requerem a coestimulação de CD86. Em contraste, em ratos diabéticos não obesos, cuja doença também é mediada por resposta do tipo $\mathrm{T}_{\mathrm{H}} 1$, o bloqueio seletivo de CD80 piorou a doença, ao passo que o bloqueio de CD86 teve um efeito benéfico. Embora os resultados produzidos pelo bloqueio seletivo de CD80 ou CD86 in vivo tenham sido contraditórios, os papéis de CD80 e CD86 podem variar dependendo do status da resposta imune ou da APC utilizada na resposta (Zhu et al., 2005).

Os trabalhos mostram que a alta susceptibilidade a infecções bacterianas nos RN prematuros tem sido atribuída também à imaturidade do sistema imune inato, incluindo os TLR (Clapp, 2006; Levy, 2007; Sadeghi et al., 2007). Estudos clínicos e com animais têm mostrado a baixa expressão de TLR-2 e TLR-4, assim como função diminuída na produção de citocinas induzidas por seus agonistas no momento do nascimento de RN pré-termos (Awasthi et al., 2008; Bessler et al., 2001; Currie et al., 2011; Förster-Waldl et al., 2005; Harju et al., 2001; Hillman et al., 2008; Levy et al., 2004; Thornton et al., 2012).

A expressão da molécula TLR-4 foi analisada na população de monócitos mostrando um aumento da expressão no Grupo 1 em relação aos outros RN, não sendo observada diferença estatística significativa da expressão desta molécula entre monócitos neonatais e de adultos, confirmando os dados descritos na literatura por Sadeghi et al. (2007). Porém os dados descritos por Yerkovich et al. (2007) mostram que, após o estimulo, os niveis da expressão de TLR-4 aumentam rapidamente, em particular na população de células mononucleares de sangue de cordão umbilical, o que não foi visto em nossos resultados. Os monócitos em cultura, especificamente do Grupo 1, apresentaram mesmo em ausência de estímulo diferença estatística significativa quando comparado aos outros grupos de RN, o que não foi observado na imunofenotipagem do sangue total, podendo supor que a manipulação das células na cultura possa ter influenciado nestes resultados. A diminuição da expressão de TLR-4 na superficie dos monócitos observada após o estímulo pode ser decorrente da 
internalização e rápida reciclagem do complexo CD14-TLR-4-MD2 entre a membrana plasmática e o complexo de Golgi (Bosshart, Heinzelmann, 2011; Latz et al., 2003).

Os diferentes estímulos microbianos, após o reconhecimento através do receptor Toll-like, desencadeiam uma série de eventos que promovem a ativação de cascatas de sinalização intracelular, levando a transcrição de inúmeros genes, dentre os quais os das citocinas envolvidas em funções efetoras e de regulação. Existem resultados discordantes no que se refere à capacidade de produção de citocinas em resposta aos inúmeros estímulos microbianos ao nascimento, como também ao longo da infância, porém a maioria dos dados sugere uma diferença na natureza da resposta de citocinas produzidas por monócitos e DC neonatais e não uma incapacidade na produção de citocinas pelos neonatos (Chelvarajan et al., 2007; Scott et al., 1997; Upham et al., 2002). Dados da literatura, mostram resultados de déficit substancial na produção de citocinas do tipo $\mathrm{T}_{\mathrm{H}} 1$, as quais estão envolvidas na proteção contra patógenos intracelulares, como IFNs do tipo I,

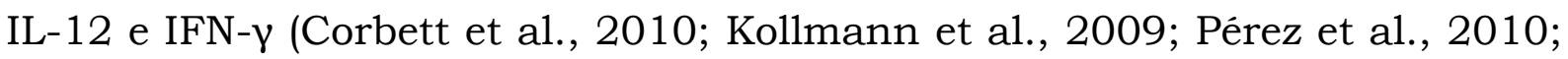
Yerkovich et al., 2007). Estudos mostram ainda citocinas neonatais centrais na defesa do hospedeiro relacionadas à inflamação aguda e a resposta do tipo $\mathrm{T}_{\mathrm{H}} 17$, contra bactérias extracelulares ou fungos, com uma produção robusta ou, em alguns casos, pouco diminuída (Lewis, Wilson, 2011).

No presente trabalho, as citocinas pró-inflamatórias IL-6, TNF- $\alpha$ e IL$1 \beta$ dosadas após o estímulo foram sensivelmente mais altas nos RN quando comparados aos adultos. Com relação à citocina IL-8, estudos descrevem os RN prematuros com maior produção quando comparados aos adultos, sendo que outros estudos não mostram níveis superiores desta citocina em RN, condizente com os nossos resultados (Schultz, et al., 2002; Dembinski et al., 2002; Angelone et al., 2006; Yerkovich et al., 2007; Corbett et al., 2010). Outros estudos mostram a produção de citocinas pró- inflamatórias TNF- $\alpha$, IL-6 e IL-8 reduzida em RN a termo e pré-termo (De Wit et al., 2003; Levy et al., 2006; Sadeghi et al., 2007). O estudo dos monócitos neonatais mostrou certa inconstância de dados a respeito da produção de citocinas. Os desenhos das populações amostrais de RN mostram uma diversidade de 
peculiaridades, as quais são utilizadas para classificar estes RN, desde a idade gestacional, o peso ao nascimento, patologias da mãe, infecção antes ou durante o parto, intercorrências durante o trabalho de parto, como também o tipo de parto realizado. Razão pela qual os dados de vários estudos realizados com esta população, muitas vezes parecem contraditórios.

Em geral, o perfil imunológico do RN é funcionalmente distinto, possivelmente como reflexo das necessidades do ambiente fetal e para evitar respostas imunes a antígenos maternos. A prevenção ou tratamento de infecções que requerem a imunidade do tipo $\mathrm{T}_{\mathrm{H}} 1$ (contra os agentes patogênicos intracelulares) podem necessitar de uma reorientação, pelo menos parcial e reversivel, da polarização do tipo $\mathrm{T}_{\mathrm{H}} 2$ presente no $\mathrm{RN}$ (Cuenca et al., 2013).

Respostas de citocinas neonatais são frequentemente descritas como polarizadas para os perfis $\mathrm{T}_{\mathrm{H}} 2$ ou $\mathrm{T}_{\mathrm{H}} 17$ (Adkins et al., 2004; Aksoy et al., 2007; De Wit et al., 2003), ou seja, com um desvio para as respostas imunes anti-inflamatória ou inata, o que prejudica o desenvolvimento da polarização para a resposta $\mathrm{T}_{\mathrm{H}} 1$ (Zaghouani et al., 2009; Zhu, Paul, 2008). Assim, em resposta a diversos estímulos, incluindo a maioria dos agonistas de TLR, as células mononucleares do sangue do cordão umbilical de RN quando testadas in vitro apresentam uma acentuada polarização, com a produção diminuida de citocinas $\mathrm{T}_{\mathrm{H}} 1$, tais como IFN- $\gamma$ e IL-12p70 e o aumento da produção de $\mathrm{T}_{\mathrm{H}} 2 / \mathrm{T}_{\mathrm{H}} 17$ e citocinas anti-inflamatórias, tais como IL-6, IL-10, IL-17, e IL-23, o que os deixa particularmente vulneráveis à infecção por patógenos intracelulares. Já os RN prematuros também apresentam produção inferior de citocinas do padrão $\mathrm{T}_{\mathrm{H}} 17$, como também da expressão proteinas do complemento e de peptídeos antimicrobianos, que contribuem ainda mais para a susceptibilidade aos patógenos (Belderbos et al., 2009; Cuenca et al., 2013; Sadeghi et al., 2007).

No que se refere à citocina anti-inflamatória IL-10 é aparente a reduzida produção desta citocina pelos grupos de RN quando comparados aos adultos em nosso trabalho, em acordo com alguns relatos (Chheda et al., 1996; Jones et al., 1996; Schultz et al., 2007). Em trabalho realizado por 
Kotiranta-Ainamo et al. (1997) foi demonstrado que a citocina IL-10 é produzida em menor quantidade por células mononucleares do sangue de cordão umbilical em relação as do sangue periférico de adultos após estímulo com E. coli.

Os relatos disponíveis sugerem que ambos, RN pré-termo e a termo, produzem niveis aumentados de citocinas pró-inflamatórias (Berner et al., 2002; Goepfert et al., 2004; Yoon et al., 2003). Entretanto, a presença de resposta anti-inflamatória compensatória adequada ainda é controversa e pode ser influenciada por antígenos bacterianos específicos (Dembinski et al., 2002; Ng et al., 2003; Schultz et al., 2007). No trabalho desenvolvido por Tatad et al. (2008) foram encontrados níveis crescentes de produção das citocinas IL-10 e IL-12 por monócitos em resposta a E. coli de acordo com a idade gestacional em grupos de RN pré-termo e a termo comparados aos adultos. Neste mesmo trabalho, os monócitos dos neonatos mostraram uma resposta anti-inflamatória downregulada para as diferentes bactérias utilizadas como estímulo. Os autores discutem que a resposta elevada de IL8 e IL-6 para E. coli patogênica no RN prematuro pode ocasionar uma resposta inflamatória descontrolada, enquanto a resposta mais baixa de IL-6 para Staphylococcus epidermidis pode indicar uma base para a vulnerabilidade à infecção por este patógeno. As diferenças na resposta de citocinas observadas são indicadores funcionais do papel da especificidade bacteriana nas vias de ativação de TLR das células do sistema imune inato. Daí pode-se constatar a inconstância de dados referentes à produção de citocinas em diversos estudos na população neonatal, considerando a diversidade ambiental em que este RN está inserido e os patógenos com que ele entra em contato.

Em trabalho realizado por Peoples et al. (2009), monócitos de RN a termo têm resposta anti-inflamatória reduzida dirigida a E. coli em relação aos RN pré-termo. Foi constatado ainda que os linfócitos T neonatais, em resposta a $E$. coli, têm nível de produção de IL-10 reduzido quando comparados com adultos. No trabalho de Kotiranta-Ainamo et al. (1997) também foi mostrado que a proporção de linfócitos T naive $\mathrm{CD} 4{ }^{+} \mathrm{CD} 45 \mathrm{RA}{ }^{+} \mathrm{de}$ $\mathrm{RN}$ a termo apresentou-se inversamente correlacionada com resposta de IL- 
10 ao LPS, sugerindo uma possivel exigência da maturação de células T para a produção de IL-10.

Em nossas culturas, a metodologia escolhida para a separação dos monócitos resultou na presença de certo número de linfócitos, portanto, a presença dessas células poderia ter contribuído para a maior quantidade de IL-10 presente no sobrenadante de cultura de monócitos de adultos.

Os mecanismos que regulam a resposta do TLR devem ser controlados, primeiramente para responder corretamente ao desafio patogênico e, segundo, para evitar a excessiva ativação da via de sinalização do TLR e, assim, controlar os danos prejudiciais causados no hospedeiro após a ativação desse receptor. Este cenário pode contribuir para o aumento da sintese de citocinas pró-inflamatórias nos neonatos, o que pode sugerir uma incapacidade de controlar a inflamação, insinuando um desequilíbrio da resposta imune neonatal (Gomez et al., 1998; Martinot et al., 1997).

Considerando-se uma diminuição na produção da citocina antiinflamatória IL-10 nos RN, uma regulação da inflamação deficiente pode contribuir para o aumento da síntese de citocinas pró-inflamatórias em RN a termo e prematuros demonstrado no presente estudo. Em vista disso, a alta incidência de complicações graves, como a sepse em RN a termo e lesão cerebral, displasia broncopulmonar e enterocolite necrosante em prematuros, podem ser iniciadas pela incapacidade de controlar a inflamação. Por esse motivo, a hipótese de que um desequilíbrio entre citocinas pró e anti-inflamatórias em favor da cascata pró-inflamatória desempenha um papel central na fisiopatologia de várias doenças neonatais.

Até o momento, o LPS tem sido o estímulo mais consistente e melhor caracterizado para a produção de IL-10 por células mononucleares. A ativação de monócitos humanos por LPS in vitro resulta na rápida produção de citocinas pró-inflamatórias, incluindo TNF- $\alpha$, IL-1 e IL-6, seguido mais tarde da secreção das moléculas anti-inflamatórias IL-10, sTNFR e IL-1Ra, que regulam ou antagonizam os mediadores pró-inflamatórios. A cinética de produção de citocinas levou à sugestão de que diferentes mecanismos reguladores são envolvidos na expressão de citocinas pró e antiinflamatórias. 
A transdução de sinal após a ativação por LPS leva a ativação de tirosina-quinases (Sadeghi et al., 2007), a proteina quinase C (Yan et al., 2004) e as MAPK (Mitogen-activated protein kinase) p38, ERK e JNK (Aksoy et al., 2007; De Wit et al., 2003). Enquanto o papel das MAPK na sinalização induzida por LPS é provavelmente o melhor caracterizado, a relação entre a ativação destas moléculas de sinalização e a indução de expressão de citocinas em RN ainda necessita ser mais bem elucidada.

Em estudo realizado por Foey et al. (1998) foi investigada a regulação da produção de IL-10 por monócitos após a estimulação com LPS. Os resultados demonstraram o envolvimento da IL-1 endógena derivada de monócitos na produção de IL-10 induzida por LPS e, além disso, confirmaram a importância da produção endógena de TNF- $\alpha$ na secreção de IL-10. Demonstraram ainda que as MAPK p38 e ERK diferencialmente regulam a produção das citocinas IL-10, IL-1 $\beta$ e TNF- $\alpha$ por monócitos. Foi demonstrado que a via ERK não está envolvida na produção de IL-10 por monócitos estimulados por LPS. Por outro lado, a produção de TNF- $\alpha$ e de IL-1 $\beta$ induzida por LPS foi parcialmente inibida por PD98059, um inibidor de MEK1, indicando que estas citocinas pró-inflamatórias são, até certo ponto, dependentes da via ERK. Quanto à p38, foi mostrado que sua inibição pelo SB203580 (um composto piridinil imidazol), resultou na completa inibição da produção de IL-10 induzida por LPS. Também foi verificado que a secreção de IL-10 induzida por LPS em macrófagos é extremamente sensivel aos inibidores da p38 (Chelvarajan et al., 2006).

Tem sido demonstrado que as respostas mediadas por TLR podem ser divididas em via dependente da proteína MyD88 e via independente da MyD88, a qual é dependente da proteína TRIF. Além disso, é discutido que as citocinas que são hiperexpressas por células mononucleares do sangue de cordão, ou seja, as citocinas pró-inflamatórias, são uniformemente dependentes de MyD88, ao passo que aquelas citocinas cuja produção é atenuada em sangue de cordão e lactentes (IL-12p35, IL-18, IL-23p19) são controladas por mecanismos dependentes de TRIF (Goriely et al., 2006; Weighardt et al., 2004). 
$\mathrm{Na}$ maioria dos casos, defeitos nas proteínas de sinalização após a estimulação de TLR, críticas para função da resposta imune inata eficaz, tais como as deficiências de IRAK-4 ou MyD88 (Picard et al., 2010), estão presentes no início da vida, quer imediatamente após o parto ou durante os primeiros meses de vida (Kawai, Akira, 2011).

Foi relatado que leucócitos de sangue do cordão umbilical demonstram redução da expressão de MyD88, deficiência na fosforilação da p38 e

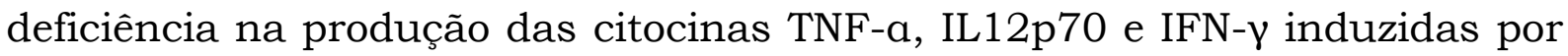
LPS (Belderbos et al., 2009; Sadeghi et al., 2007; Yan et al., 2004). Por outro lado, os leucócitos de RN demonstram um aumento relativo da produção, mediada por TLR, das citocinas do perfil $\mathrm{T}_{\mathrm{H}} 2 / \mathrm{T}_{\mathrm{H}} 17$, tais como IL-6 e IL-10, em comparação com adultos (Belderbos et al., 2009; Sadeghi et al., 2007). Este fenômeno de diminuição da resposta das citocinas $T_{H} 1$ também foi demonstrado em animais recém-nascidos (Chelvarajan et al., 2007).

Com relação à ERK-1/2 e p38, Sadeghi et al. (2007) constataram que estas moléculas apresentaram menor fosforilação, em comparação com adultos, após o estímulo nos RN pré-termos e a termo, significativa apenas para o RN a termo, o que poderia culminar na deficiente ativação do fator de transcrição AP-1 e consequente menor produção de citocinas próinflamatórias. No presente trabalho, observamos resultados aparentemente contrários, onde ERK-1/2 e p38 mostraram-se ativadas (fosforiladas) e adequadamente expressas, em relação aos adultos, com nível de expressão de ERK-1/2 e p38 mais elevado nos RN do Grupo 1. Estes resultados condizem com a maior produção de citocinas pró-inflamatórias por RN observadas em nossas culturas. No entanto, não explica a menor produção de IL-10.

Dados da literatura sugerem que fatores que elevam cAMP estão envolvidos na regulação da produção de IL-10 por monócitos, principalmente ao nivel de mRNA (Alvarez et al., 2010). A regulação da produção de IL-10 tem sido o objeto de intensa pesquisa em modelos dependentes do estímulo de TLR-4 e ambos os mecanismos transcricionais e pós-transcricionais têm sido relatados como envolvidos nessa produção. No que diz respeito à regulação da transcrição, muitos fatores de transcrição foram considerados 
reguladores importantes, tais como, Sp1 e Sp3 (Tone et al., 2000), c-Maf (Cao et al., 2005), NF-Y (Lin, 2006), NF-kB (Cao et al., 2006), Pbx1b (Chung et al., 2007), NFAT (Goodridge et al., 2007), e CREB (Hu et al., 2006). No entanto, Alvarez et al. (2010) verificaram que o bloqueio da atividade do NFkB por dois inibidores diferentes levou a um aumento da produção de IL-10. Em contraste, os tratamentos que atuam sobre o fator de transcrição CREB, incluindo prostaglandina E2 $\left(\mathrm{PGE}_{2}\right)$ mostrou uma correlação direta entre a sua ativação e produção de IL-10. Quanto ao presente trabalho, não foram observadas diferenças na ativação do NF-kB entre os grupos.

De grande importância tanto quanto a avaliação da produção de citocinas pelos monócitos neonatais é a avaliação da atividade fagocítica e do "burst" oxidativo em monócitos e neutrófilos, que foi realizada a fim de determinar o potencial das células fagocíticas de debelar o patógeno, não desconsiderando inúmeros fatores que contribuem para a eficiência destas funções, como: números adequados de monócitos e neutrófilos, habilidade de responder a sinais dos sítios de inflamação, migração para estes sítios e a capacidade de ingerir e matar o invasor. Como a produção de fagócitos e seu bom funcionamento são cruciais para um mecanismo imunológico bactericida eficaz, uma atividade ineficiente dessas células pode aumentar a vulnerabilidade a infecções dos RN (Lewis, Wilson, 2011).

Em nosso trabalho, monócitos e, principalmente, neutrófilos neonatais apresentam um aumento discreto da porcentagem da capacidade fagocítica de E. coli de acordo com a idade gestacional, mas estas células nos adultos são significativamente mais eficientes neste processo, sendo correspondente a quantidade de bactérias fagocitadas, mensuradas através da Média de Intensidade de Fluorescência (MFI). Estes dados obtidos estão em concordância com trabalho de Filias et al. (2011), o qual demonstra que os monócitos e neutrófilos de RN possuem sua capacidade fagocítica prejudicada em comparação com os adultos.

A disfunção dos neutrófilos neonatais, já bem estabelecida, o que é particularmente importante em RN prematuros, é comum e contribui para a maior incidência de infecções em crianças em todo o mundo. A disfunção de polimorfonucleares (PMN) neonatais é descrita como uma característica 
fundamental da sepse no RN (Koenig, Yoder, 2004; Petrova, Mehta, 2007). PMN isolados de RN prematuros apresentam fagocitose comprometida, uma diminuição da capacidade de geração de radicais de oxigênio e morte bacteriana intracelular deficiente em comparação com neutrófilos de adultos saudáveis, mesmo quando estudados em uma aparente ausência de estresse fisiológico ou desafio infeccioso para o RN (Carr, 2000; Gahr et al., 1985; Petrova, Mehta, 2007).

Os mecanismos microbicidas de fagócitos consistem em uma combinação de processos de enzimáticos e oxidativos que são ativados após a fagocitose. Quando o microrganismo é fagocitado, a célula aumenta seu consumo de oxigênio molecular o que acaba resultando na produção de espécies reativas de oxigênio, as quais são essenciais para a morte bacteriana, através do burst respiratório, e de substâncias bactericidas que são liberadas dos grânulos citoplasmáticos dentro do fagolisossomo (Carr, 2000; Roos et al., 2003). Uma relativa diminuição da capacidade fagocitária, reduzida geração de espécies reativas de oxigênio e menores níveis de elastase e lactoferrina contribuem para a morte bacteriana deficiente em neutrófilos neonatais (Petrova, Mehta, 2007).

As análises das porcentagens de fagócitos produtores de $\mathrm{H}_{2} \mathrm{O}_{2}$ e o $\mathrm{MFI}$, representando a quantidade produzida destas moléculas, mostrou que os RN são capazes de gerar burst oxidativo após fagocitose de E. coli. De um modo geral, a análise dos fagócitos produtores de peróxido de hidrogênio mostrou uma diminuição do MFI dos RN pré-termos, em especial do Grupo 1, revelando uma produção de peróxido de hidrogênio deficiente, o que poderia ocasionar uma reduzida morte intracelular dos microrganismos.

Analisando a porcentagem dos monócitos produtores de $\mathrm{H}_{2} \mathrm{O}_{2}$ mediante estímulo, esta se apresentou reduzida em pré-termos quando comparados ao Grupo 3 e aos adultos. Há relatos nos estudos realizados por Moriguchi et al. (2006) e Fleer et al. (1988) que mostram um reduzido "burst" oxidativo dos fagócitos neonatais de um modo geral, em conformidade com os nossos resultados dos RN pré-termo, sugerindo que a degradação bacteriana não é eficaz. 
Quanto aos neutrófilos, estes apresentaram em todos os grupos capacidade de gerar "burst" oxidativo, com produção de $\mathrm{H}_{2} \mathrm{O}_{2}$ após estímulo com PMA, no entanto, os adultos apresentaram frequência significativamente maior de neutrófilos produtores de $\mathrm{H}_{2} \mathrm{O}_{2}$ quando comparados aos RN. Após a fagocitose de E. coli, foi observada uma menor porcentagem de neutrófilos produtores de $\mathrm{H}_{2} \mathrm{O}_{2}$ nos $\mathrm{RN}$ do Grupo 2 quando comparados aos adultos. Quanto à análise do MFI, foram observadas diferenças estatísticas na produção de $\mathrm{H}_{2} \mathrm{O}_{2}$ pelos neutrófilos, onde os adultos tiveram uma produção significativamente maior quando comparados aos dois grupos de pré-termos. O trabalho realizado por Björkqvist et al. (2004) mostra RN prematuros com uma menor capacidade de regular o burst oxidativo de neutrófilos após a estimulação bacteriana em relação aos $\mathrm{RN}$ a termo, porém não estatisticamente significativa, reforçando os nossos dados acima citados.

Uma atividade recém-reconhecida de PMN de individuos adultos foi relatada na qual neutrófilos geram armadilhas extracelulares, ou "NETs", para bactérias Gram-positivas e negativas. NETs são “redes" formadas por fibras extracelulares e DNA, histonas, enzimas granulares e proteínas antimicrobianas liberadas pelos PMN após sua ativação. A NET parece ser uma forma de resposta inata, que se liga a microrganismos, evita a sua propagação e garante uma elevada concentração local de agentes antimicrobianos para degradar fatores de virulência e matar as bactérias. São abundantes in vivo em disenteria experimental e apendicite humana espontânea, dois exemplos de inflamação aguda (Brinkmann et al., 2004).

Em estudo realizado por Yost et al. (2009) verificou-se que neutrófilos neonatais de RN a termo apresentam uma diminuição na formação de NETs e a contenção bacteriana extracelular e atividade microbicida por este mecanismo também podem ser fatores determinantes da morte microbiana deficiente observada em infecções neonatais graves, como sepse e pneumonia. Como a gravidade da disfunção de neutrófilos neonatais é, em geral, relacionada ao grau de maturação do desenvolvimento, a atividade microbicida extracelular de neutrófilos em RN prematuros é provável que 
também esteja comprometida, podendo ser ainda mais profunda em bebês muito prematuros, com idade gestacional entre 28 e 32 semanas.

Em outro trabalho, está descrito que neutrófilos de RN a termo apresentam fagocitose, geração de oxidantes e morte bacteriana intracelular normal quando examinadas em condições basais, porém as funções antibacterianas são drasticamente comprometidas quando PMN isolados de bebês com suspeita de sepse ou dificuldade respiratória são estudados. Assim, defeitos na capacidade antimicrobiana são basicamente presentes em neutrófilos de RN prematuros e podem ser detectados em PMN de neonatos a termo, quando infectados ou submetidos a estresse fisiológico ou desafio inflamatório (Shigeoka et al., 1979).

Uma observação interessante em nosso trabalho e condizente com o relato acima é que monócitos e neutrófilos de $\mathrm{RN}$ com sepse tardia foram analisados quanto à sua capacidade fagocítica e produção de peróxido de hidrogênio em paralelo com nossas amostras de RN saudáveis (dados não mostrados). Foram observadas porcentagens de fagocitose muito inferiores pelos fagócitos dos RN com sepse em relação aos RN saudáveis e adultos. Quanto ao peróxido de hidrogênio, observou-se uma menor produção pelos RN com sepse somente quando comparados aos RN a termo e adultos.

Tendo em vista os dados dos últimos 30 anos relacionados à fagocitose, é difícil estabelecer a interpretação e a correlação entre os resultados, em virtude da diversidade de parâmetros envolvidos, considerando ainda a variedade de técnicas utilizadas para a investigação da função fagocítica de monócitos e neutrófilos. Muitos fatores podem participar da regulação da homeostasia do pool de neutrófilos e monócitos dos neonatos nos primeiros dias após o nascimento, como a produção de citocinas, diminuição de hormônios, maturação dos macrófagos, substâncias transferidas pelo aleitamento materno, como CD14 solúvel, entre outros. Alguns destes fatores podem ter um efeito sobre a função celular e podem ser responsáveis pela diminuição da capacidade fagocítica mostrada nos estudos (Filias et al., 2011).

Diante de todos os resultados aqui apresentados, ainda permanecem questões a respeito das diferenças funcionais dos componentes do sistema 
imune inato de neonatos de diferentes idades gestacionais e deles em relação aos adultos e quais mecanismos poderiam regular as diferentes respostas. Deve-se lembrar de que um maior grau de comprometimento é mais provável de ser encontrado nos RN que nascem em torno de 30 semanas de idade gestacional ou menos, os quais não foram analisados no presente trabalho.

Vários investigadores enfocaram a epigenética para descrever por que as consequências funcionais da ativação de TLR em RN são tão marcadamente diferentes da dos adultos, em especial os micro RNA (miRNA). Os miRNA são pequenos RNA que inibem a expressão de certos genes póstranscricionais. Eles participam do controle de muitos processos imunológicos e biológicos. Em particular, o miRNA 146a ou miR146a tem sido descrito como regulador funcional da sinalização de TLR-4 através da inibição da IRAK-4, IRAK-1 e TRAF-6 e parece ter um papel na tolerância a endotoxina. Surpreendentemente, os monócitos do sangue do cordão têm uma maior expressão de miR146a em comparação com os adultos (Lederhuber et al., 2011).

Polimorfismos genéticos ou mutações em proteínas chave de sinalização de TLR podem levar a um aumento da suscetibilidade a infecção ou sepse. Por exemplo, os pacientes com deficiência de MyD88 são mais suscetiveis a infecções bacterianas recorrentes (Picard et al., 2010). Resultados similares foram observados em pacientes com deficiência de IRAK-4. Além disso, neutrófilos de pacientes com deficiência de IRAK-4 mostraram-se ser hiporresponsivos ao LPS devido a falha em regular positivamente os marcadores de ativação de superficie celular e mostrarem baixa atividade fagocítica (Bouma et al., 2009). Pacientes com mutação no NEMO (NF-kappa B essential modulator), uma subunidade do $\mathrm{IkB}$, que é responsável pela ativação do NF-kB, também são extremamente suscetiveis a infecções piogênicas (Orange et al., 2004). Como MyD88, IRAK-4 e NF-kB são todas proteínas de sinalização utilizadas por muitos dos TLR, não é nenhuma surpresa que estes pacientes manifestem suscetibilidades e fenótipos clínicos semelhantes (Cuenca et al., 2013).

Os nossos resultados consistem em uma avaliação abrangente da resposta imune inata mediada por TLR-4 em RN pré-termo e a termo. Em 
um panorama geral do nosso trabalho foi possivel verificar que o Grupo 1 de RN pré-termo moderado apresentou níveis basais (na ausência de estímulo) reduzidos de expressão de TLR-4 e CD80 em pDC e mDC, número reduzido de monócitos, menor concentração de CD14 solúvel, como também da expressão da molécula coestimuladora CD40 em linfócitos B em relação ao Grupo de RN a termo.

Sabendo que a quantificação destas moléculas não é suficiente para caracterizar a capacidade funcional do sistema imune inato destes RN, avaliamos a capacidade fagocítica e a produção de peróxido de hidrogênio por monócitos e neutrófilos, as quais também foram reduzidas nos RN prétermo. Entretanto funcionalmente os monócitos em cultura foram capazes de responder ao estímulo, apresentando uma expressão semelhante dos marcadores de ativação, das proteínas da cascata de sinalização intracelular e uma alta produção de citocinas pro-inflamatórias em relação aos adultos. A menor produção de IL-10 no sobrenadante de cultura de monócitos, não somente pelo Grupo 1, como também pelos outros RN, pode indicar que a resposta imune inata neonatal não sofre simplesmente de uma deficiência quantitativa, em comparação aos adultos, mas pode ser caracterizada por um padrão de resposta que é qualitativamente distinto. Deste modo, o neonato não apresenta uma imaturidade funcional, mas sim, um desequilíbrio em sua resposta imune inata, com uma aparente menor produção de fatores anti-inflamatórios, o que pode levar a predisposição à sepse. 
6 CONCLUSÕES 
Os resultados mostram um perfil imunológico neonatal funcionalmente distinto, revelando um desequilíbrio da resposta imune inata, com uma menor eficiência no controle desta resposta, o que pode levar a uma predisposição à sepse.

1. A análise das diferentes populações de leucócitos do sangue total revelou números absolutos elevados em RN quando comparados aos adultos, devido à característica leucocitose neonatal. A expressão de TLR-4 em DC neonatais foi reduzida em relação aos adultos, o que não foi observado nos monócitos.

2. Monócitos de RN pré-termo e a termo responderam bem ao estímulo antigênico via TLR-4 com niveis semelhantes de expressão de marcadores de ativação CD80 e CD86, porém niveis reduzidos de expressão de HLA-DR e CD40 e com alta produção das citocinas próinflamatórias TNF- $\alpha$, IL-1 $\beta$, IL-6 e reduzida produção de IL-10.

3. Monócitos e neutrófilos neonatais apresentam capacidade fagocítica de Escherichia coli reduzida em relação aos adultos. A geração do burst oxidativo por monócitos e neutrófilos foi reduzida nos RN pré-termo, o que poderia ocasionar uma reduzida morte intracelular deste microrganismo.

4. Monócitos neonatais mostraram, de modo geral, ativação semelhante aos adultos das moléculas envolvidas na cascata de sinalização intracelular após estímulo via TLR-4, o que está de acordo com a alta produção de citocinas pró-inflamatórias nos sobrenadantes de cultura de monócitos. 
REFERENCIAS 


\section{REFERÊNCIAS *}

Abe K, Shapiro-Mendoza CK, Hall LR, Satten GA. Late preterm birth and risk of developing asthma. J Pediatr. 2010;157:74-8.

Adams S, O'Neill DW, Bhardwaj N. Recent advances in dendritic cell biology. J Clin Immunol. 2005;25:177-88.

Adkins B, Leclerc C, Marshall-Clarke S. Neonatal adaptive immunity comes of age. Nat Rev Immunol. 2004;4:553-64.

Akira S. Mammalian Toll-like receptors. Curr Opin Immunol. 2003;15:5.

Akira S, Takeda K. Toll-like receptor signaling. Nature Reviews Immunology. 2004;4:499-511.

Akira S, Uematsu S, Takeuchi O. Pathogen recognition and innate immunity. Cell. 2006;124:783-801.

Aksoy E, Albarani V, Nguyen M, Laes JF, Ruelle JL, De Wit D, Willems F, Goldman M, Goriely S. Interferon regulatory factor 3-dependent responses to lipopolysaccharide are selectively blunted in cord blood cells. Blood. 2007; 109:2887-93.

Alvarez Y, Valera I, Municio C, Hugo E, Padrón F, Blanco L, Rodríguez M, Fernández N, Crespo MS. Eicosanoids in the innate immune response: TLR and non-TLR routes. Mediators Inflamm. 2010;2010. pii: 201929.14 p.

Angelone DF, Wessels MR, Coughlin M, Suter EE, Valentini P, Kalish LA, Levy O. Innate immunity of the human newborn is polarized toward a high ratio of IL-6/TNF- production in vitro and in vivo. Pediatr Res. 2006; 60:2059.

Arancibia SA, Beltrán CJ, Aguirre IM, Silvia P, Peralta AL, Malinarich F, Hermoso MA. Toll-like receptors are key participants in innate immune responses. Biol Res. 2007;40:97-112.

Arnon S, Litmanovitz I. Diagnostic tests in neonatal sepsis. Curr Opin Infect Dis. 2008;21:223-7.

\footnotetext{
*De acordo com:

International Committee of Medical Journal Editors. [Internet]. Uniform requirements for manuscripts submitted to Biomedical Journal: sample references. [updated 2011 Jul 15]. Available from: http://www.icmje.org
} 
Awasthi S, Cropper J, Brown KM. Developmental expression of Toll like receptors-2 and -4 in preterm baboon lung. Dev Comp Immunol. 2008;32:1088-98.

Belderbos ME, van Bleek GM, Levy O, Blanken MO, Houben ML, Schuijff L, Kimpen JLL, Bont L. Skewed pattern of Toll-like receptor 4-mediated cytokine production in human neonatal blood: low LPS-induced IL-12p70 and high IL-10 persist throughout the first month of life. Clin Immunol. 2009; 133(2):228-37.

Belderbos ME, Levy O, Stalpers F, Kimpen JL, Meyaard L, Bont L. Neonatal plasma polarizes TLR4-mediated cytokine responses towards low IL-12p70 and high IL-10 production via distinct factors. PLoS One. 2012;7(3):e33419.

Berner R, Welter P, Brandis M. Cytokine expression of cord and adult blood mononuclear cells in response to Streptococcus agalactiae. Pediatr Res. 2002;51:304-9.

Berrington JE, Barge D, Fenton AC, Cant AJ, Spickett GP. Lymphocyte subsets in term and significantly preterm UK infants in the first year of life analyzed by single platform flow cytometry. Clin Exp Immunol. 2005; 140:289-92.

Bessler H, Komlos L, Punsky I, Ntambi JA, Bergman M, Straussberg R, Sirota L. CD14 receptor expression and lipopolysaccharide-induced cytokine production in preterm and term neonates. Biol Neonate. 2001;80:186-92.

Beutler B. The Toll-like receptors: analysis by forward genetic methods. Immunogenetics. 2005;57:385-92.

Birle A, Nebe CT, Gessler P. Age-related low expression of HLADR molecules on monocytes of term and preterm newborns with and without signs of infection. J Perinatol. 2003;23:294-9.

Blencowe H, Cousens S, Oestergaard MZ, Chou D, Moller AB, Narwal R, Adler A, Vera Garcia C, Rohde S, Say L, Lawn JE. National, regional, and worldwide estimates of preterm birth rates in the year 2010 with time trends since 1990 for selected countries: a systematic analysis and implications. Lancet. 2012;379:2162-72.

Björkqvist M, Jurstrand M, Bodin L, Fredlund H, Schollin J. Defective Neutrophil Oxidative Burst in Preterm Newborns on Exposure to CoagulaseNegative Staphylococci. Pediatric Research. 2004;(55):966-71.

Bonac B, Derganc M, Wraber B, Hojker S. Interleukin-8 and procalcitonin in early diagnosis of early severe bacterial infection in critically ill neonates. Pflugers Archives: Europ J Physiol. 2000;440:R72-R74.

Bosshart H, Heinzelmann M. Spontaneous decrease of CD14 cell surface expression in human peripheral blood monocytes ex vivo. $\mathrm{J}$ Immunol Methods. 2011;368(1-2):80-3. 
Bouma G, Doffinger R, Patel SY, Peskett E, Sinclair JC, Barcenas-Morales G, Cerron-Gutierrez L, Kumararatne DS, Davies EG, Thrasher AJ, Burns SO. Impaired neutrophil migration and phagocytosis in IRAK-4 deficiency. $\mathrm{Br} \mathrm{J}$ Haematol. 2009;147:153-6.

Brinkmann V, Reichard U, Goosmann C, Fauler B, Uhlemann Y, Weiss DS, Weinrauch Y, Zychlinsky A. Neutrophil extracellular traps kill bacteria. Science. 2004;303:1532-5.

Cao S, Liu J, Song L, Ma X. The protooncogene c-Maf is an essential transcription factor for IL-10 gene expression in macrophages. J Immunol. 2005; 174(6):3484-92.

Cao S, Zhang X, Edwards JP, Mosser DM. NF-kappa B1 (p50) homodimers differentially regulate pro- and anti-inflammatory cytokines in macrophages. J Biol Chem. 2006;281(36):26041-50.

Carr R, Modi N. Haemopoietic colony stimulating factors for preterm neonates. Arch Dis Child Fetal Neonatal. 1997;(76):128-33.

Carr R. Neutrophil production and function in newborn infants. $\mathrm{Br} \mathrm{J}$ Haematol. 2000;110:18-28.

Chheda S, Palkowetz KH, Garofalo R, Rassin DK, Goldman AS. Decreased interleukin-10 production by neonatal monocytes and $\mathrm{T}$ cells: relationship to decreased production and expression of tumor necrosis factor- $\alpha$ and its receptors. Pediatr Res. 1996;40:475-83.

Chelvarajan L, Popa D, Liu Y, Getchell TV, Stromberg AJ, Bondada S. Molecular mechanisms underlying anti-inflammatory phenotype of neonatal splenic macrophages. J Leukoc Biol. 2007;82:403-16.

Chelvarajan RL, Liu Y, Popa D, Getchell ML, Getchell TV, Stromberg AJ, Bondada S. Molecular basis of age-associated cytokine dysregulation in LPSstimulated macrophages. J Leukoc Biol. 2006;79(6):1314-27.

Chensue SW, Remick DG, Shmyr-Forsch C, Beals TF, Kunkel SL. Immunohistochemical demonstration of cytoplasmic and membraneassociated tumor necrosis factor in murine macrophages. Am J Pathol. 1988; 133:564-72.

Chirico G, Loda C. Laboratory aid to the diagnosis and therapy of infection in the neonate. Pediatr Rep. 2011;3:e1.

Chung EY, Liu J, Homma Y, Zhang Y, Brendolan A, Saggese M, Han J, Silverstein R, Selleri L, Ma X. Interleukin-10 expression in macrophages during phagocytosis of apoptotic cells is mediated by homeodomain proteins Pbx1 and Prep-1. Immunity. 2007;27(6):952-64.

Clapp DW. Developmental regulation of the immune system. Semin Perinatol. 2006;30:69-72. 
Cohen-Wolkowiez M, Moran C, Benjamin DK, Michael Cotten, MD, MHS, Reese H. Clark, MD, Daniel K. Benjamin Jr., Brian PS. Early and late onset sepsis in late preterm infants. Pediatr Infect Dis J. 2009;28:1052-6.

Collin M, McGovern N, Haniffa M. Human dendritic cell subsets. Immunology. 2013;140:22-30.

Corbett NP, Blimkie D, Ho KC, Cai B, Sutherland DP, Kallos A, Crabtree J, Rein-Weston A, Lavoie PM, Turvey SE, Hawkins NR, Self SG, Wilson CB, Hajjar AM, Fortuno III ES, Kollmann TR. Ontogeny of Toll-Like Receptor Mediated Cytokine Responses of Human Blood Mononuclear Cells. Plos One. 2010;5(11):e15041.

Christensen RD, Henry E, Jopling J, Wiedmeier SE. The CBC: reference ranges for neonates. Semin Perinatol. 2009;33:3-11.

Cuenca AG, Wynn JL, Moldawer LL, Levy O. Role of Innate Immunity in Neonatal Infection. Am J Perinatol. 2013;30(2):105-12.

Currie AJ, Curtis S, Strunk T, Riley K, Liyanage K, Prescott S, Doherty D, Simmer K, Richmond P, Burgner David. Preterm infants have deficient monocyte and lymphocyte cytokine responses to group B streptococcus. Infect Immun. 2011;(79):1588-96.

Curtis MG, Walker B, Denny TN. Flow cytometric methods for prenatal and neonatal diagnosis. J Immunol Methods. 2011;363:198-209.

Dembinski J, Behrendt D, Reinsberg J, Bartmann P. Endotoxin-stimulated production of IL-6 and IL- 8 is increased in short-term cultures of whole blood from healthy term neonates. Cytokine. 2002;18:116-9.

de Vries E, de Groot R, de Bruin-Versteeg S, Comans-Bitter WM, van Dongen JJ. Analysing the developing lymphocyte system of neonates and infants. Eur J Pediatr. 1999;158:611-7.

De Wit D, Tonon S, Olislagers V, Goriely S, Boutriaux M, Goldman M, Willems F. Impaired responses to toll-like receptor 4 and tool-like receptor 3 ligands in human cord blood. J Autoimmun. 2003;21:277-81.

Dollner H, Vatten L, Austgulen R. Early diagnostic markers for neonatal sepsis: Comparing C-reactive protein, interleukin-6, soluble tumour necrosis factor receptors and soluble adhesion molecules. $J$ Clin Epidemiol. $2001 ; 54: 1251-7$.

Driscoll MS, Thomas VL, Ramamurthy RS, Casto DT. Longitudinal evaluation of polymorphonuclear leukocyte chemiluminescence in premature infants. J Pediatr. 1990;116:429-34.

Drohan L, Harding JJ, Holm B, Cordoba-Tongson E, Dekker CL, Holmes T, Maecker H, Mellins ED. Selective developmental defects of cord blood antigen-presenting cell subsets. Hum Immunol. 2004;65(11):1356-69. 
Durandy A, De Saint Basile G, Lisowska-Grospierre B, Gauchat JF, Forveille M, Kroczek RA, Bonnefoy JY, Fischer A. Undetectable CD40 ligand expression on $\mathrm{T}$ cells and low $\mathrm{B}$ cell responses to CD40 binding agonists in human newborns. J Immunol. 1995;154:1560-8.

Escobar GJ, Clark RH, Greene JD. Short-term outcomes of infants born at 35 and 36 weeks gestation: we need to ask more questions. Semin Perinatol. 2006;30:28-33.

Filias A, Theodorou GL, Mouzopoulou S, Varvarigou AA, Mantagos S, Karakantza M. Phagocytic ability of neutrophils and monocytes in neonates. BMC Pediatr. 2011;11:29.

Foey AD, Parry SL, Williams LM, Feldmann M, Foxwell BMJ, Brennan F M. Regulation of Monocyte IL-10 Synthesis by Endogenous IL-1and TNF-a: Role of the p38 and p42/44 Mitogen-Activated Protein Kinases. J Immunol. 1998;160:920-8.

Fitzgerald KA, Palsson-McDermott EM, Bowie AG, Jefferies CA, Mansell AS, Brady G, Brint E, Dunne A, Gray P, Harte MT, McMurray D, Smith DE, Sims JE, Bird TA, O'Neill LA. Mal (MyD88-adapter-like) is required for Toll-like receptor-4 signal transduction. Nature. 2001;413(6851):78-83.

Fleer A, Gerards LJ, Verhoef J: Host defence to bacterial infection in the neonate. J Hosp Infect. 1988;11:320-27.

Forster-Waldl E, Sadeghi K, Tamandl D, Gerhold B, Hallwirth U, Rohrmeister K, Hayde M, Prusa AR, Herkner K, Boltz-Nitulescu G, Pollak A, Spittler A. Monocyte toll-like receptor 4 expression and LPS-induced cytokine production increase during gestational aging. Pediatr Res. 2005;58:121-4.

Fujii S, Liu K, Smith C, Bonito A, Steinman R. The linkage of innate to adaptive immunity via maturing dendritic cells in vivo requires CD40 ligation in addition to antigen presentation and CD80/86 costimulation. J Exp Med. 2004;199:1607-18.

Gahr M, Blanke R, Speer CP. Polymorphonuclear leukocyte function in term and preterm newborn infants. Biol Neonate. 1985;48:15-20.

Geissmann F, Manz MG, Jung S, Sieweke MH, Merad M, Ley K. Development of monocytes, macrophages, and dendritic cells. Science. 2010;327(5966):656-61.

Goepfert AR, Andrews WW, Carlo W, Ramsey PS, Cliver SP, Goldenberg RL, Hauth JC. Umbilical cord plasma interleukin-6 concentrations in preterm infants and risk of neonatal morbidity. Am $J$ Obstet Gynecol. 2004;191:1375-81.

Gomez R, Romero R, Ghezzi F, Yoon BH, Mazor M, Berry SM. The fetal inflammatory response syndrome. Am J Obstet Gynecol. 1998;179:194-202. 
Goodridge HS, Simmons RM, Underhill DM. Dectin-1 stimulation by Candida albicans yeast or zymosan triggers NFAT activation in macrophages and dendritic cells. J Immunol. 2007;178(5):3107-15.

Gordon S, Taylor PR. Monocyte and macrophage heterogeneity. Nature Rev Immunol. 2005;5:953-64.

Goriely S, Molle C, Nguyen M, Albarani V, Haddou NO, Lin R, De Wit D, Flamand V, Willems F, Goldman M. Interferon regulatory factor 3 is involved in Toll-like receptor 4 (TLR4)- and TLR3-induced IL-12p35 gene activation. Blood. 2006;107:1078-84.

Gulubova MV, Ananiev JR, Vlaykova TI, Yovchev Y, Tsoneva V, Manolova IM. Role of dendritic cells in progression and clinical outcome of colon cancer. Int J Colorectal Dis. 2012;27:159-69.

Guasch XD, Torrent FR, Martínez-Nadal S, Cerén CV, Saco MJ, Castellví PS. Late preterm infants: a population at underestimated risk. An Pediatr (Barc). 2009;71:291-98.

Hamilton BE, Martin JA, Ventura SJ. Births: preliminary data for 2009. Natl Vital Stat Rep. 2010;59:1-19.

Hartel C, Adam N, Strunk T, Temming P, Muller-Steinhardt M, Schultz C. Cytokine responses correlate differentially with age in infancy and early child- hood. Clin Exp Immunol. 2005; 142:446-53.

Heininger U, Riffelmann M, Leineweber B, Wirsing von Koenig $\mathrm{CH}$. Maternally derived antibodies against Bordetella pertussis antigens pertussis toxin and filamentous hemagglutininin preterm and full term newborns. Pediatr Infect Dis. 2009;28;443-45.

Heldrup J, Kalm O, Prellner K. Blood T and B lymphocyte subpopulations in healthy infants and children. Acta Paediatr. 1992;81:125-32.

Henneke P, Golenbock DT. TIRAP: how Toll receptors fraternize. Nat Immmunol. 2001;2(9):828-30.

Hillman NH, Moss TJ, Nitsos I, Kramer BW, Bachurski CJ, Ikegami M, Jobe AH, Kallapur SG. Toll-like receptors and agonist responses in the developing fetal sheep lung. Pediatr Res. 2008;63:388-93.

Hirschfeld M, Ma Y, Weis JH, Vogel SN, Weis JJ. Cutting Edge: repurification of lipopolysaccharide eliminates signaling through both human and murine Toll-like receptor 2. J Immunol. 2000;165:618-22.

Hoebe K, Janssen E, Beutler B. The interface between innate and adaptive immunity. Nat Immunol. 2004;5(10):971-74.

Horng T, Barton GM, Medzhitov R. TIRAP: an adapter molecule in the Toll signaling pathway. Nat Immunol. 2001;2(9):835-41. 
Howson CP, Kinney MV, Lawn JE. Born Too Soon: The Global Action Report on Preterm Birth. Reproductive Health. 2013;10(Suppl 1):S1.

Holmlund U, Hoglind A, Larsson AK, Nilsson C, Sverremark Ekström E. CD14 and development of atopic disease at 2 years of age in children with atopic or non-atopic mothers. Clin Exp Allergy. 2003;33:455.

Hu X, Paik PK, Chen J, Yarilina A, Kockeritz L, Lu TT, Woodgett JR, Ivashkiv LB. IFN-gamma suppresses IL-10 production and synergizes with TLR2 by regulating GSK3 and CREB/AP-1 proteins. Immunity. 2006;24(5):563-74.

Hunt CE. Ontogeny of autonomic regulation in late preterm infants born at 34-37 weeks postmenstrual age. Semin Perinatol. 2006;30:73-6.

Ito T, Liu YJ, Kadowaki N. Functional diversity and plasticity of human dendritic cell subsets. Int J Hematol. 2005;81:188-96.

Janeway CA Jr, Medzhitov R. Innate immune recognition. Annu Rev Immunol. 2002;20:197-216.

Jones CA, Cayabyab RG, Kwong KYC, Stotts C, Wong B, Hamdan H, Minoo $\mathrm{P}$, DeLemos RA. Undetectable interleukin (IL)-10 and persistent IL-8 expression early in hyaline membrane disease: a possible developmental basis for the predisposition to chronic lung inflammation in preterm newborns. Pediatr Res.1996;39:966-75.

Kadowaki N, Ho S, Antonenko S, Malefyt RW, Kastelein RA, Bazan F, Liu YJ. Subsets of human dendritic cell precursors express different toll-like receptors and respond to different microbial antigens. $J$ Exp Med. 2001; 194:863-69.

Kadowaki N. The divergence and interplay between $\mathrm{pDC}$ and $\mathrm{mDC}$ in humans. Frontiers in bioscience: a journal and virtual library. 2009;14:80817.

Kalinski P, Vieira PL, Schuitemaker JH, de Jong EC, Kapsenberg ML. Prostaglandin $\mathrm{E}(2)$ is a selective inducer of interleukin-12 p40 (IL-12p40) production and an inhibitor of bioactive IL-12p70 heterodimer. Blood. 2001;97:3466-9.

Källman J, Schollin J, Schalèn C, Erlandsson A, Kihlström E. Impaired phagocytosis and opsonisation towards group B strep- tococci in preterm neonates. Arch Dis Child Fetal Neonatal. 1998;78:46-50.

Kanakoudi-Tsakalidou F, Debonera F, Drossou-Agakidou V, Sarafidis K, Tzimouli V, Taparkou A, Kremenopoulos G. Flow cytometric measurement of HLA-DR expression on circulating monocytes in healthy and sick neonates using monocyte negative selection. Clin Exp Immunol. 2001;123:402-7.

Kawai T, Akira S. Toll-like receptors and their crosstalk with other innate receptors in infection and immunity. Immunity. 2011;34:637-50. 
Khashu M, Narayanan M, Bhargava S, Osiovich H. Perinatal outcomes associated with preterm birth at 33 to 36 weeks' gestation: a populationbased cohort study. Pediatrics. 2009;123:109-13.

Keyworth N, Millar MR, Holland KT. Development of cutaneous microflora in premature neonates. Arch Dis Child. 1992;67:797-801.

Klein JO. Bacterial sepsis and meningitis. In: Remington JS, Klein JO, eds. Infectious Diseases of the Fetus, Newborn, and Infants. 5th ed. Philadelphia,PA: WB Saunders; 2001:943-84.

Koenig JM, Yoder MC. Neonatal neutrophils: the good, the bad, and the ugly. Clin Perinatol. 2004;31:39-51.

Kollmann TR, Crabtree J, Rein-Weston A, Blimkie D, Thommai F, Wang XY, Lavoie PM, Furlong J, Fortuno III ES, Hajjar AM, Hawkins NR, Self SG, Wilson CB. Neonatal Innate TLR-Mediated. J Immunol. 2009;183:7150-60.

Kopp E, Medzhitov R. Recognition of microbial infection by Toll-like receptors. Curr Opin Immunol. 1999;15(4):396-401.

Kotiranta-Ainamo A, Rautonen J, Rautonen N. Interleukin-10 production by cord blood mononuclear cells. Pediatr Res. 1997;41:110-13.

Koumbi LJ, Papadopoulos NG, Anastassiadou V, Machaira M, Kafetzis DA, Papaevangelou V. Dendritic cells in uninfected infants born to hepatitis B virus-positive mothers. Clin Vaccine Immunol. 2010;17:1079-85.

Krediet TG, Wiertsema SP, Vossers MJ, Hoeks SB, Fleer A, Ruven HJ, Rijkers GT. Toll-like receptor 2 polymorphism is associated with preterm birth. Pediatr Res. 2007;62:474-6.

Kumar H, Kawai T, Akira S. Pathogen recognition in the innate immune response. Biochem J. 2009;420:1-16.

Latz E, Visintin A, Lien E, Fitzgerald KA, Espevik T, Golenbock DT. The LPS receptor generates inflammatory signals from the cell surface. J Endotoxin Res. 2003;9(6):375.

Lawn JE, Cousens S, Zupan J. 4 million neonatal deaths: when? Where? Why? Lancet. 2005;365:891-900.

Lederhuber H, Baer K, Altiok I, Sadeghi K, Herkner KR, Kasper DC. MicroRNA-146: tiny player in neonatal innate immunity? Neonatology. 2011;99:51-6.

Lekkou A, Karakantza M, Mouzaki A, Kalfarentzos F, Gogos CA. Cytokine production and monocyte HLA-DR expression as predictors of outcome for patients with community-acquired severe infections. Clin Diagn Lab Immunol. 2004;11:161-7. 
Lemaitre B, Nicolas E, Michaut L, Reichhart JM, Hoffmann JA. The dorsoventral regulatory gene cassette spatzle/toll/cactus controls the potent antifungal response in Drosophila adults. Cell. 1996 Sep 20;86(6):973-83.

Levy O. Antimicrobial proteins and peptides: anti-infective molecules of mammalian leukocytes. J Leukoc Biol. 2004;76:909-25.

Levy O. Innate immunity of the newborn: basic mechanisms and clinical correlates. Nature Rev Immunol. 2007;7:379-90.

Levy O, Coughlin M, Cronstein BN, Roy RM, Desai A, Wessels MR. The Adenosine System Selectively Inhibits TLR-Mediated TNF-a Production in the Human Newborn. J Immunol. 2006;177(3):1956-66.

Levy O, Zarember KA, Roy RM, Cywes C, Godowski PJ, Wessels MR. Selective impairment of TLR-mediated innate immunity in human newborns: neonatal blood plasma reduces monocyte TNF-alpha induction by bacterial lipopeptides, lipopolysaccharide, and imiquimod, but preserves the response to R-848. J Immunol. 2004;173:4627-34.

Lewis DB, Wilson CB. Developmental immunology and role of host defenses in neonatal susceptibility to infection. In: Remington JS, Klein JO, editors. Infectious Diseases of the Fetus and Newborn Infant. 7 th ed. Philadelphia:Elsevier Saunders; 2011;80-190.

Lin SC. Identification of an NF-Y/HMG-I(Y)-binding site in the human IL-10 promoter. Mol Immunol. 2006;43(9):1325-31.

Lisonkova S, Hutcheon JA, Joseph KS. Temporal trends in neonatal outcomes following iatrogenic preterm delivery. BMC Pregn Childbirth. 2011;11:39.

Liu L, Johnson HL, Cousens S, Perin J, Scott S, Lawn JE, Rudan I, Campbell H, Cibulskis R, Li M, Li M, Mathers C, Black RE. Global, regional, and national causes of child mortality: an updated systematic analysis for 2010 with time trends since 2000. Lancet. 2012; 379:2151-61.

Martin JA, Hamilton BE, Sutton PD, Ventura SJ, Mathews TJ, Osterman MJ. Births: final data for 2008. National Vital Statistics Reports; vol. 59, no.1. Hyattsville, MD: National Center for Health Statistics; 2010.

Martinot A, Leclerc F, Cremer R, Leteurtre S, Fourier C, Hue V. Sepsis in neonates and children: definitions, epidemiology, and outcome. Pediatr Emerg Care. 1997;13:277-81

McGreal EP, Hearne K, Spiller OB. Off to a slow start: Under-development of the complement system in term newborns is more substantial following premature birth. Immunobiology. 2012;217:176-86. 
McIntire DD, Leveno KJ. Neonatal mortality and morbidity rates in late preterm births compared with births at term. Obstet Gynecol. 2008;111:3541.

Medzhitov R, Janeway C Jr. Innate immune recognition: mechanisms and pathways. Immunol Rev. 2000;173:89-97.

Meem M, Modak JK, Mortuza R, Morshed M, Islam MS, Saha SK.. Biomarkers for diagnosis of neonatal infections: a systematic analysis of their potential as a point-of-care diagnostics. J. Glob. Health. 2011;1:201-9.

Melville JM, Moss TJM. The immune consequences of preterm birth. Frontier in neuroscience. 2013;7:1-9.

Mescher M, Curtsinger J, Agarwal P, Casey K, Gerner M, Hammerbeck CD, Popescu F, Xiao Z. Signals required for programming effector and memory development by CD8 T cells. Immunol Rev. 2006;211:81-92.

Milcic TL. The complete blood count. Neonatal Netw. 2010;29(2):109-15.

Moriguchi N, Yamamoto S, Isokawa S, Andou A, Miyata H: Granulocyte functions and changes in ability with age in newborns; Report no.1: Flow cytometric analysis of granulocyte functions in whole blood. Pediatr Int. 2006;48(1): 17-21.

Néron S, Nadeau PJ, Darveau A, Leblanc JF. Tuning of CD40-CD154 Interactions in Human B-Lymphocyte Activation: A Broad Array of In Vitro Models for a Complex In Vivo Situation. Arch Immunol Ther Exp. 2011;59:25-40.

Ng PC, Li K, Chui KM, Leung TF, Wong RP, Chu WC, Wong E, Fok TF. IP-10 is an early diagnostic marker for identification of late-onset bacterial infection in preterm infants. Pediatr Res. 2007;61(1):93-8.

Ng PC, Li K, Wong RP, Chui K, Wong E, Li G, Fok TF. Proinflammatory and anti-inflammatory cytokine responses in preterm infants with systemic infections. Arch Dis Child Fetal Neonatal Ed. 2003;88:F209-13.

Nguyen M, Leuridan E, Zhang T, De Wit D, Willems F, Van Damme P, Goldman M, Goriely S. Acquisition of adult-like TLR4 and TLR9 responses during the first year of life. PLoS ONE. 2010;5(4):e10407.

Nonoyama S, Penix LA, Edwards CP, Lewis DB, Ito S, Aruffo A, Wilson CB, Ochs HD. Diminished expression of CD40 ligand by activated neonatal $\mathrm{T}$ cells. J Clin Invest. 1995;95:66-75

Notarangelo LD, Lanzi G, Peron S, Durandy A. Defects of class-switch recombination. J Allergy Clin Immunol. 2006;1 17:855-64.

Nussbaum C, Sperandio M. Innate immune cell recruitment in the fetus and neonate. J Reprod Immunol. 2011;90(1):74-81. 
O'Neill LA, Bowie AG. The family of five: TIR-domain-containing adaptors in Toll-like receptor signaling. Nat Rev Immunol. 2007;7(5):353-64.

Orange JS, Jain A, Ballas ZK, Schneider LC, Geha RS, Bonilla FA. The presentation and natural history of immunodeficiency caused by nuclear factor kappa B essential modulator mutation. J Allergy Clin Immunol. 2004;113:725-33.

Paino IMM, Ximenes VF, Fonseca LM, Kanegae MPP, Khalil NM, Brunetti IL. Effect of therapeutic plasma concentrations of non-steroidal antiinflammatory drugs on the production of reactive oxygen species by activated rat neutrophils. Braz J Med Biol Res. 2005;38:543-51.

Palmeira P, Quinello C, Silveira-Lessa AL, Zago CA, Carneiro-Sampaio M. IgG placental transfer in healthy and pathological pregnancies. Clin Dev Immunol. 2012; 2012:985646.13p.

Peoples JD, Cheung S, Nesin M, Lin H, Tatad AM, Hoang D, Perlman JM, Cunningham-Rundles S. Neonatal cord blood subsets and cytokine response to bacterial antigens. Am J Perinatol. 2009;26:647-57.

Pérez A, Bellon JM, Gurbindo MD, Munoz-Fernandez MA. Impairment of stimulation ability of very-preterm neonatal monocytes in response to lipopolysaccharide. Hum Immunol. 2010;71(2):151-7.

Pérez A, Gurbindo MD, Resino S, Aguarón A, Muñoz-Fernández MA. NK Cell Increase in Neonates from the Preterm to the Full-Term Period of Gestation. Neonatology. 2007;92:158-63.

Petrova A, Mehta R. Dysfunction of innate immunity and associated pathology in neonates. Indian J Pediatr. 2007;74:185-91.

Picard C, von Bernuth $\mathrm{H}$, Ghandil P, Chrabieh M, Levy O, Arkwright PD, McDonald D, Geha RS, Takada H, Krause JC, Creech CB, Ku CL, Ehl S, Maródi L, Al-Muhsen S, Al-Hajjar S, Al-Ghonaium A, Day-Good NK, Holland SM, Gallin JI, Chapel H, Speert DP, Rodriguez-Gallego C, Colino E, Garty BZ, Roifman C, Hara T, Yoshikawa H, Nonoyama S, Domachowske J, Issekutz AC, Tang M, Smart J, Zitnik SE, Hoarau C, Kumararatne DS, Thrasher AJ, Davies EG, Bethune C, Sirvent N, de Ricaud D, Camcioglu Y, Vasconcelos J, Guedes M, Vitor AB, Rodrigo C, Almazán F, Méndez M, Aróstegui JI, Alsina L, Fortuny C, Reichenbach J, Verbsky JW, Bossuyt X, Doffinger R, Abel L, Puel A, Casanova JL. Clinical features and outcome of patients with IRAK-4 and MyD88 deficiency. Medicine (Baltimore). 2010;89:403-25.

Prokesová L, Lodinová-Zádníková R, Zizka J, Kocourková I, Novotná O, Petrásková P, Sterzl I. Cytokine levels in healthy and allergic mothers and their children during the first year of life. Pediatr Allergy Immunol. 2006; 17:175-83. 
Protonotariou E, Malamitsi-Puchner A, Giannaki G, Rizos D, Phocas I, Sarandakou A. Patterns of inflammatory cytokine serum concentrations during the perinatal period. Early Hum Dev. 1999;56:31-8.

Quezada SA, Jarvinen LZ, Lind EF, Noelle RJ. CD40/CD154 interactions at the interface of tolerance and immunity. Annu Rev Immunol. 2004;22:30728.

Raju TN, Higgins RD, Stark AR, Leveno KJ. Optimizing care and outcome for late-preterm (near-term) infants: a summary of the workshop sponsored by the National Institute of Child Health and Human Development Pediatrics. 2006; 118:1207-14.

Ramachandrappa A, Jain L. Health issues of the late preterm infant. Pediatr Clin North Am. 2009;56:565-77.

Harju K, Glumoff V, Hallman M. Ontogeny of Toll-like receptors Tlr2 and Tlr4 in mice. Pediatr Res. 2001;49:81-3.

Ryan WL, Mounira H, Candice CS, Clint MC, David FL, Emily AD. Late preterm birth. Rev Obstet Gynecol. 2010;3:10-9.

Remington JS, Klein JO, Wilson CB, Nizet V, Maldonado YA. Infectious Diseases of the Fetus and Newborn Infant. 7th ed. Philadelphia,PA:WB Saunders; 2011:24.

Rizos D, Protonotariou E, Malamitsi-Puchner A, Trakakis E, Sarandakou A, Salamalekis E. Inflammatory cytokines and their soluble receptors during delivery and early life. Acta Obstet Gynecol Scand. 2005;84:817-8.

Roos D, van Bruggen R, Meischl C. Oxidative Killing of microbes by neutrophils. Microbes Infect. 2003;5:1307-15.

Rothe G, Oser A, Valet G. Dihydrorhodamine 123: a new flow cytometric indicator for respiratory burst activity in neutrophil granulocytes. Naturwissenschaften. 1988;75:354-5.

Sadeghi K, Berger A, Langgartner M, Prusa AR, Hayde M, Herkner K, Pollak A, Spittler A, Forster-Waldl E. Immaturity of infection control in preterm and term newborns is associated with impaired toll-like receptor signaling. $\mathrm{J}$ Infect Dis. 2007;195(2):296-302.

Sanchez-Schmitz G, Levy O. Development of newborn and infant vaccines. Sci Trans1 Med. 2011;3(90):90ps27.

Sanchez-Torres C, Garcia-Romo G S, Cornejo-Cortes M A, Rivas-Carvalho A, Sanchez-Schmitz G. CD16+ and CD16- human blood monocyte subsets differentiate in vitro to dendritic cells with different abilities to stimulate CD4+ T cells. Int Immunol. 2001;13:1571-81. 
Santana C, Guindeo MC, González G, García-Muñoz F, Saavedra P, Doménech E. Cord blood levels of cytokines as predictors of early neonatal sepsis. Acta Paediatr. 2001;90:1176-81.

Schreibelt G, Tel J, Sliepen HEWJ, Benitez-Ribas D, Figdor CG, Adema GJ, de Vries IJM. Toll-like receptor expression and function in human dendritic cell subsets: implications for dendritic cell-based anti-cancer immunotherapy. Cancer immunology, immunotherapy: CII. 2010;59:157382.

Schultz C, Rott C, Temming P, Schlenke P, Möller JC, Bucsky P. Enhanced interleukin-6 and interleukin- 8 synthesis in term and preterm infants. Pediatr Res Pediatr Res. 2002;51:317-22.

Schultz C, Strunk T, Temming P, Matzke N, Härtel C. Reduced IL-10 production and -receptor expression in neonatal $\mathrm{T}$ lymphocytes. Acta Paediatr. 2007;96(8):1122-5.

Scott ME, Kubin M, Kohl S. High level interleukin-12 production, but diminished interferon-gamma production, by cord blood mononuclear cells. Pediatr Res. 1997;41:547-53.

Shapiro-Mendoza CK, Tomashek KM, Kotelchuck M, Barfield W, Nannini A, Weiss J, Declercq E. Effect of late-preterm birth and maternal medical conditions on newborn morbidity risk. Pediatrics. 2008;121:e223-32.

Sharma AA, Jen R, Butler A, Lavoie PM. The developing human preterm neonatal immune system: a case for more research in this area. Clin Immunol. 2012;145:61-8.

Shaw RR. Late preterm birth: a new nursing issue. MCN Am J Matern Child Nurs. 2008;33:287-93.

Shigeoka AO, Santos JI, Hill HR. Functional analysis of neutrophil granulocytes from healthy, infected, and stressed neonates. J Pediatr. 1979;95:454-60.

Shimazu R, Akashi S, Ogata H, Nagai Y, Fukudome K, Miyake K, Kimoto M. MD-2, a molecule that confers lipopolysaccharide responsiveness on Toll-like receptor 4. J Exp Med. 1999;189(11):1777-82.

Sorg RV, Kogler G, Wernet P. Identification of cord blood dendritic cells as an immature CD11c-population. Blood. 1999;93:2302-7.

Stoll BJ, Hansen N, Fanaroff AA, Wright LL, Carlo WA, Ehrenkranz RA, Lemons JA, Donovan EF, Stark AR, Tyson JE. Late-onset sepsis in very low birth weight neonates: the experience of the NICHD Neonatal Research Network. Pediatrics. 2002;110:285-91. 
Strunk T, Currie A, Richmond P, Simmer K, Burgner D. Innate immunity in human newborn infants: prematurity means more than immaturity. J Matern Fetal Neonatal Med. 2011;24(1):25-31.

Swierzko AS, Atkinson AP, Cedzynski M, MacDonald SL, Szala A, Domzalska-Popadiuk I, Borkowska-Klos M, Jopek A, Szczapa J, Matsushita M, Szemraj J, Turner ML, Kilpatrick DC. Two factors of the lectin pathway of complement, 1-ficolin and mannan-binding lectin, and their associations with prematurity, low birth weight and infections in a large cohort of Polish neonates. Mol Immunol. 2009;46:551-8.

Szabolcs P, Park K-D, Reese M, Marti L, Broadwater G, Kurtzberg J. Coexistent na1 $\square$ ve phenotype and higher cycling rate of cord blood T cells as compared to adult peripheral blood. Experimental Hematology. 2003;(31)8:708-14.

Széles L, Keresztes G, Töröcsik D, Balajthy Z, Krenács L, Póliska S, Steinmeyer A, Zuegel U, Pruenster M, Rot A, Nagy L.1,25-dihydroxyvitamin D3 is an autonomous regulator of the transcriptional changes leading to a tolerogenic dendritic cell phenotype. J Immunol. 2009;182:2074-83.

Tanel A, Fonseca SG, Yassine-Diab B, Bordi R, Zeidan J, Shi Y, Benne C, Sékaly RP. Cellular and molecular mechanisms of memory T-cell survival. Expert Rev Vaccines. 2009;8:299-312.

Tatad AMF, Nesin M, Peoples J, Cheung S, Lin H, Sison C, Perlman J. Cunningham-Rundles $\mathrm{S}$. Cytokine expression in response to bacterial antigens in preterm and term infant cord blood monocytes. Neonatology. 2008;94:8-15.

Thaxton JE, Nevers TA, Sharma S. TLR-Mediated Preterm Birth in Response to Pathogenic Agents. Infectious Diseases in Obstetrics and Gynecology. 2010;1-8.

Tomashek KM1, Shapiro-Mendoza CK, Davidoff MJ, Petrini JR. Differences in mortality between late-preterm and term singleton infants in the United States, 1995-2002. J Pediatr. 2007;151(5):450-6.

Tone M, Powell MJ, Tone Y, Thompson SA, Waldmann H. IL-10 gene expression is controlled by the transcription factors $\mathrm{Sp} 1$ and $\mathrm{Sp} 3 . \mathrm{J}$ Immunol. 2000;165(1):286-91.

Thornton NL, Cody MJ, Yost CC. Toll-like receptor $1 / 2$ stimulation induces elevated interleukin-8 secretion in polymorphonuclear leukocytes isolated from preterm and term newborn infants. Neonatology. 2012;101:140-6.

Upham JW, Lee PT, Holt BJ, Heaton T, Prescott SL, Sharp MJ, Sly PD, Holt PG. Development of interleukin-12-producing capacity throughout childhood. Infect Immun. 2002;70:6583-8. 
van den Berg JP, Westerbeek EAM, vander Klis FRM, Berbers GAM, van ElBurg RM. Transplacental transport of IgG antibodies to preterm infants: a review of the literature. Early Hum Dev. 2011;87:67-72.

van Gent R, van Tilburg CM, Nibbelke EE, Ottoa SA, Gaisera JF, JanssensKorpelaa PL, Sandersb EAM, Borghansa JAM, Wulffraatb NM, Bieringsc MB, Bloema AC, Tesselaar K. Refined characterization and reference values of the pediatric T- and B-cell compartments. Clin Immunol. 2009;133:95-107.

Velilla PA, Rugeles MT, Chougnet CA. Defective antigen-presenting cell function in human neonates. Clinical immunology. 2006;121:251-59.

Vrachnis N, Vitoratos N, Iliodromiti Z, Sifakis S, Deligeoroglou E, Creatsas G. Intrauterine inflammation and preterm delivery. Ann N Y Acad Sci. 2010;1205:118-22.

Walker JC, Smolders MA, Gemen EF, Antonius TA, Leuvenink J, de Vries E. Development of lymphocyte subpopulations in preterm infants. Scand $\mathrm{J}$ Immunol. 2011;73:53-8.

Wang ML, Dorer DJ, Fleming MP, Catlin E. Clinical outcomes of near-term infants. Pediatrics. 2004;114:372-76.

Weighardt H, Jusek G, Mages J, Lang R, Hoebe K, Beutler B, Holzmann B. Identification of a TLR4- and TRIF-dependent activation program of dendritic cells. Eur J Immunol. 2004;34:558-64.

World Health Organization (WHO). Mortality data. Available from: www.who.int/healthinfo/statistics/mortality/en/. [2014 março 19]

Wynn JL, Wong HR. Pathophysiology and treatment of septic shock in neonates. Clin Perinatol. 2010;37:439-79.

Yan SR, Qing G, Byers DM, Stadnyk AW, Al-HertaniW, Bortolussi R. Role of MyD88 in diminished tumor necrosis factor alpha production by newborn mononuclear cells in response to lipopolysaccharide. Infect Immun. 2004;72:1223-9.

Yang J, Zhang L, Yu C, Yang Xiao-Feng, Wang H. Monocyte and macrophage differentiation:circulation inflammatory monocyte as biomarker for inflammatory diseases. Biomarker Research. 2014;2:1.

Yerkovich ST, Wikström ME, Suriyaarachchi D, Prescott SL, Upham JW, Holt PG. Postnatal development of monocyte cytokine responses to bacterial lipopolysaccharide. Pediatr Res. 2007;62:547-52.

Yoon BH, Romero R, Moon J, Chaiworapongsa T, Espinoza J, Kim YM, Edwin S, Kim JC, Camacho N, Bujold E, Gomez R. Differences in the fetal interleukin- 6 response to microbial invasion of the amniotic cavity between term and preterm gestation. J Matern Fetal Neonatal Med. 2003;13:32-8. 
Yost CC, Cody MJ, Harris ES, Thornton NL, McInturff AM, Martinez ML, Chandler NB, Rodesch CK, Albertine KH, Petti CA, Weyrich AS, Zimmerman GA. Impaired neutrophil extracellular trap (NET) formation: a novel innate immune deficiency of human neonates. Blood. 2009;113(25):6419-27.

Zaghouani H, Hoeman CM, Adkins B. Neonatal immunity: faulty T-helpers and the shortcomings of dendritic cells. Trends Immunol. 2009;30:585-91.

Zaidi AK, Huskins WC, Thaver D, Bhutta ZA, Abbas Z, Goldmann DA. Hospital-acquired neonatal infections in developing countries. Lancet. 2005;365:1175-88.

Zaidi AK, Thaver D, Ali SA, Khan TA. Pathogens Associated With Sepsis in Newborns and Young Infants in Developing Countries. Pediatr Infect Dis J. 2009;28(1):S10-8.

Zhu J, Paul WE. CD4 T cells: fates, functions, and faults. Blood. 2008;112(5):1557-69.

Zinkernagel RM. Maternal antibodies, childhood infections, and autoimmune diseases. N Engl J Med. 2001;345:1331. 
APENNDICES 
APÊNDICE A - Ficha de anamnese das parturientes 


\section{FICHA DE ANAMNESE DAS PARTURIENTES}

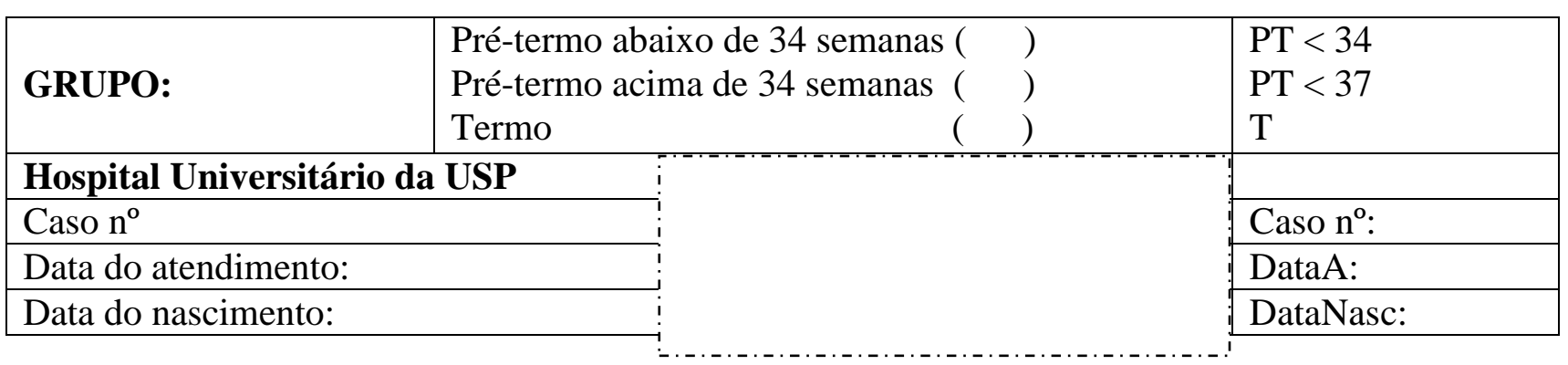

\section{Dados Maternos}

Nome:

Iniciais:

\section{Endereço}

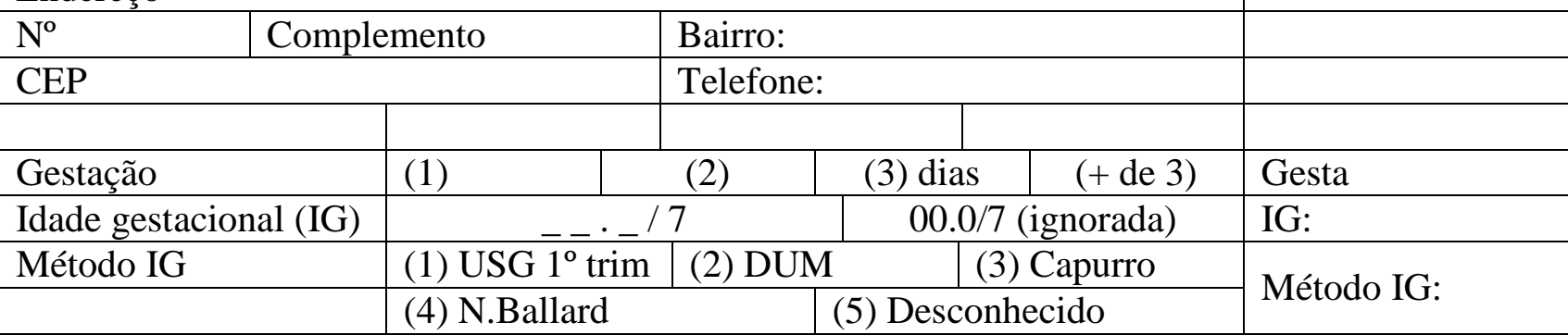

\begin{tabular}{|l|l|l|l|l|}
\hline Morbidades maternas & & \\
\hline Circlagem & (0) Ausente & (1) Presente & & Circlagem: \\
\hline Infecção: & (0) Ausente & (1) Presente & (2) Não pesquisado & Infecção: \\
\hline ITU & (0) Ausente & (1) Presente & (2) Não pesquisado & ITU: \\
\hline SGB & (0) Ausente & (1) Presente & (2) Não pesquisado & SGB: \\
\hline E. coli & (0) Ausente & (1) Presente & (2) Não pesquisado & E. coli: \\
\hline $\begin{array}{l}\text { Outras } \\
\text { Especificar }\end{array}$ & (0) Ausente & (1) Presente & (2) Não pesquisado & Outros \\
\hline
\end{tabular}

\begin{tabular}{|l|l|l|l|l|}
\hline Sorologias & & & & \\
\hline Sífilis/ VDRL & (0) Não reagente & (1) Reagente & Título: & Sifilis/VD \\
\hline Sífilis/TPPA & (0) Não reagente & (1) Reagente & (2) Não pesquisado & Siffilis/TP \\
\hline Sífilis/FTA-Abs & (0) Não reagente & (1) Reagente & (2) Não pesquisado & Sífilis/Ft \\
\hline HIV & (0) Não reagente & (1) Reagente & (2) Não pesquisado & HIV: \\
\hline CMV - IgG & (0) Não reagente & (1) Reagente & (2) Não pesquisado & CMV/IgG \\
\hline CMV - IgM & (0) Não reagente & (1) Reagente & (2) Não pesquisado & CMV/IgM \\
\hline Rubéola - IgG & (0) Não reagente & (1) Reagente & (2) Não pesquisado & Rubéloa/IgG \\
\hline Rubéola - IgM & (0) Não reagente & (1) Reagente & (2) Não pesquisado & Rubeola/IgM \\
\hline Toxo - IgG & (0) Não reagente & (1) Reagente & (2) Não pesquisado & Toxo/IgG \\
\hline Toxo - IgM & (0) Não reagente & (1) Reagente & (2) Não pesquisado & Toxo/IgM \\
\hline Teste de avidez & (0) Alta & (1) Baixa & (2) Indeterminado & Toxo/avidez \\
\hline Hepatite C & (0) Não reagente & (1) Reagente & (2) Não pesquisado & HVC: \\
\hline Hepatite B & (0) Não reagente & (1) Reagente & (2) Não pesquisado & HVB \\
\hline HBsAg & (0) Não reagente & (1) Reagente & (2) Não pesquisado & HBsAg \\
\hline Anti-Hbs & (0) Não reagente & (1) Reagente & (2) Não pesquisado & Anti-Hbs \\
\hline HBeAg & (0) Não reagente & (1) Reagente & (2) Não pesquisado & HBeAg \\
\hline Anti-Hbe & (0) Não reagente & (1) Reagente & (2) Não pesquisado & Anti-Hbe \\
\hline Anti-Hbc & (0) Não reagente & (1) Reagente & (2) Não pesquisado & Anti-Hbc \\
\hline $\begin{array}{l}\text { Outros } \\
\text { Citar }\end{array}$ & (0) Não reagente & (1) Reagente & & \\
\hline
\end{tabular}


Doenças Maternas

\begin{tabular}{|c|c|c|c|c|}
\hline \multicolumn{2}{|l|}{ Hipertireoidismo } & (0) Ausente & (1) Presente & Hipert: \\
\hline \multicolumn{2}{|l|}{ Hipotireoidismo } & (0) Ausente & (1) Presente & Hipot: \\
\hline \multicolumn{2}{|l|}{ Diabete Melito } & (0) Ausente & (1) Presente & DM: \\
\hline \multicolumn{2}{|c|}{ Diabete gestacional } & (0) Ausente & (1) Presente & DG: \\
\hline \multicolumn{2}{|c|}{ Pneumonias } & (0) Ausente & (1) Presente & PN: \\
\hline \multicolumn{2}{|l|}{ Tuberculose } & (0) Ausente & (1) Presente & Tb: \\
\hline \multicolumn{2}{|l|}{ Febre Reumática } & (0) Ausente & (1) Presente & FR: \\
\hline \multicolumn{2}{|l|}{ Doença de Chagas } & (0) Ausente & (1) Presente & Chagas: \\
\hline \multicolumn{2}{|c|}{ Hipertensão Arterial Aguda } & (0) Ausente & (1) Presente & HASa \\
\hline \multicolumn{2}{|c|}{ Hipertensão Arterial Crônica } & (0) Ausente & (1) Presente & HASc \\
\hline \multicolumn{2}{|c|}{ Lúpus Eritematoso Sistêmico } & (0) Ausente & (1) Presente & LES: \\
\hline \multicolumn{2}{|c|}{ Artrite Reumatóide } & (0) Ausente & (1) Presente & $\mathrm{AR}$ \\
\hline \multicolumn{2}{|c|}{ Polimiosite/Dermatomiosite } & (0) Ausente & (1) Presente & $\mathrm{P} / \mathrm{D}$ \\
\hline \multicolumn{2}{|c|}{ Poliarterite Nodosa } & (0) Ausente & (1) Presente & Pnodo \\
\hline \multicolumn{2}{|c|}{$\begin{array}{l}\text { Outras Doenças auto-imunes } \\
\text { Citar }\end{array}$} & (0) Ausente & (1) Presente & Autoimune \\
\hline Alergias & (0) Ausent & (1) Presente & Qual? & Alergia \\
\hline Tabagismo & (0) Ausent & (1) Presente & $\mathrm{n}^{\circ}$ de cigarros & Tabaco \\
\hline Álcool & (0) Ausent & (1) Presente & $\mathrm{n}^{\mathrm{o}}$ doses & Álcool \\
\hline Drogas ilícitas & (0) Ausent & (1) Presente & Qual? & Drogas \\
\hline Medicamentos: & (0) Não & (1) $\mathrm{Sim}$ & Quais? & Medicamentos \\
\hline Citar: & & & & \\
\hline Corticóides & (0) Não & (1) $\mathrm{Sim}$ & & Corticoide \\
\hline
\end{tabular}

\begin{tabular}{|c|l|l|l|l|}
\hline \multicolumn{2}{|l|}{ Dados Intraparto } & (1) fórcipe & (2) cesárea & \\
\hline Tipo de parto & $(0)$ normal & (1) Adequada & (2) Inadequada & \\
\hline Profilaxia SBG & (0) não realizada & (1) Realizada & (2) não se aplica & \\
\hline Profilaxia HIV & (0) não realizada & (1) Reala & & \\
\hline & & & & \\
\hline Antibioticoterapia & & & & \\
\hline Pré-parto & (0) não realizada & (1) Realizada & & \\
\hline Intraparto & (0) não realizada & (1) Realizada & & \\
\hline
\end{tabular}

\begin{tabular}{|l|l|l|l|l|}
\hline Recém-nascidos & \multicolumn{2}{|l|}{} & \\
\hline Peso de Nascimento (PN): & PN: & \multicolumn{2}{|l|}{} & \\
\hline Gênero & (1) Masc & (2) Fem & (3) Indeterm & Gênero: \\
\hline Apgar: & Apgar1: & \multicolumn{2}{|l|}{} & Apgar1: \\
\hline & Apgar5: & & Apgar5: \\
\hline Classificação RN: & & & \\
\hline Clas.IG & (1) Pré-termo & (2) Termo & (3) Pós-termo & Clas.IG \\
\hline Clas.T & (1) PIG & (2) AIG & (3) GIG & Clas.T \\
\hline Clas.Peso & (1) Normal & (2) BP & (3) MBP & Clas.Peso \\
\hline & & & & \\
\hline Risco Infeccioso & (0) Não & (1) Sim & & \\
\hline Bolsa Rota $>18$ horas & (0) Não & (1) Sim & & \\
\hline ITU materna & (0) Não & (1) Sim & & \\
\hline Febre Materna & (0) Não & (1) Sim & & \\
\hline Corioamnionite & (0) Não & (1) Sim & & \\
\hline Procedimentos & & & & \\
\hline
\end{tabular}




\begin{tabular}{|l|l|l|l|}
\hline Procedimento cirúrgico & (0) Não & (1) Sim & Cirurgia: \\
\hline Hemorragia Intracraniana & (0) Não & (1) Sim & HIC: \\
\hline Drogas vasoativas & (0) Não & (1) Sim & Drogas vasoativas: \\
\hline Uso de hemoderivados & (0) Não & (1) Sim & Hemoderivados: \\
\hline Concentrado de hemácias & (0) Não & (1) Sim & Hemácia: \\
\hline Plasma fresco congelado & (0) Não & (1) Sim & Plasma: \\
\hline Concentrado de plaquetas & (0) Não & (1) Sim & Plaquetas: \\
\hline Gamaglobulina EV & (0) Não & (1) Sim & Gamaglob.: \\
\hline $\begin{array}{l}\text { Estimulador de colônias (granulócitos } \\
\text { neutrófilos }\end{array}$ & (0) Não & (1) Sim & Granulokine: \\
\hline
\end{tabular}

\begin{tabular}{l|l|l|l|l|l|l|l}
\hline & & Hb & HT & Leucócitos & Neutrófilos & INN & Plaquetas \\
\hline HMG & $1^{\mathbf{0}}$ exame & & & & & \\
\hline Leucócitos & $(1)>20.000 / \mathrm{mm}^{3}$ & $(2)$ Entre 20.000 e $5.000 / \mathrm{mm}^{3}$ & $(3)<5.000 / \mathrm{mm}^{3}$ \\
\hline Neutrófilos & $(1)>1750 / \mathrm{mm}^{3}$ & $(2)<1750 / \mathrm{mm}^{3}$ \\
\hline INN & $(1)>0,2$ & $(2)<0,2$ \\
\hline Plaquetas & $(1)>150.000 / \mathrm{mm} 3$ & $(2)<150.000 / \mathrm{mm}^{3}$ \\
\hline
\end{tabular}

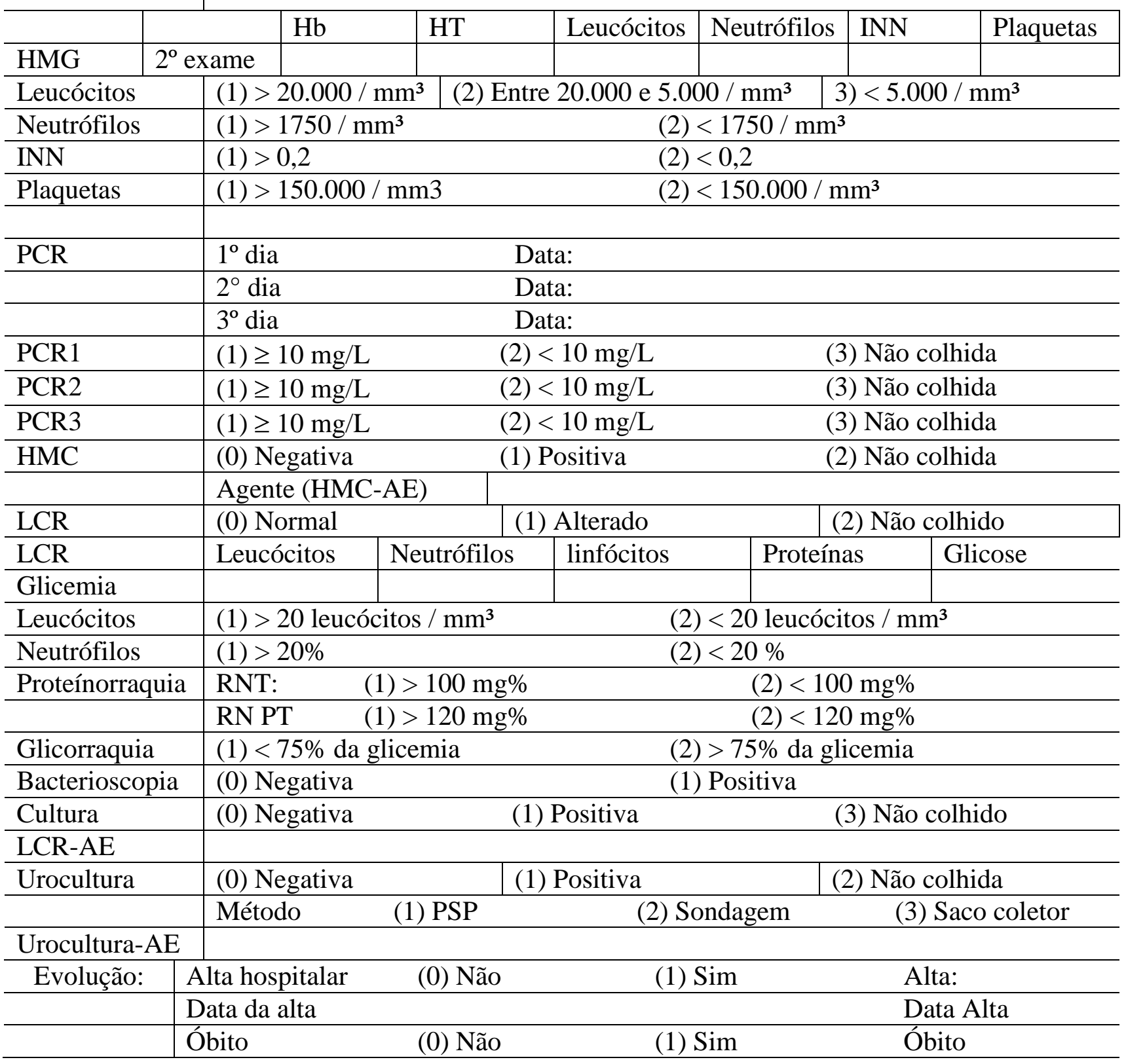


Diagnósticos:

8
0
0
0
0
0
0
0
0
0
0
0 
APÊNDICE B - Termo de consentimento livre e esclarecido 


\title{
HOSPITAL UNIVERSITÁRIO
}

\author{
da Universidade de São Paulo
}

\section{TERMO DE CONSENTIMENTO LIVRE E ESCLARECIDO}

I - TÍTULO DA PESQUISA: "Avaliação da imunidade inata do recém-nascido a termo e pré-termo: mecanismos básicos de ativação via receptores semelhantes ao Toll 4 (TLR-4) em diferentes células apresentadoras de antígenos.”

1. Justificativa e objetivos da pesquisa: Prezada Senhora, como já lhe foi falado a senhora apresenta produção de anticorpos no sangue e secreções que são importantes para a defesa do seu organismo e do organismo do seu filho contra as doenças. Além disso, o recém-nascido possui fatores de defesa imunológicos que nascem com ele, as células, que serão utilizadas por ele na defesa contra doenças, mas muitos desses fatores estão em processo natural de amadurecimento com o passar da idade. Em virtude destas condições de imaturidade do sistema imunológico do recém-nascido o objetivo deste estudo é avaliar como se encontram alguns aspectos do sistema imunológico inato do recém-nascido em diferentes idades gestacionais, visto que ele está exposto a bactérias no meio ambiente que podem causar sepse (infeç̧ão generalizada). Por este motivo, será necessária a coleta de sangue do cordão umbilical, para a realização de exames laboratoriais para avaliarmos o sistema de defesa do seu filho contra determinadas bactérias causadoras de doença em recém-nascidos. Não haverá qualquer desconforto para o recém-nascido, pois o sangue não será retirado dele e sim do cordão umbilical, depois de retirada a placenta. Caso a senhora não queira participar da pesquisa, você tem todo o direito de recusar. Caso comece na pesquisa e depois deseje desistir, também estará garantida assistência médica para a sua criança.

2. procedimentos que serão utilizados e propósitos, incluindo a identificação dos procedimentos que são experimentais: Será colhido sangue do cordão umbilical para avaliar imunidade inata do recém-nascido a termo e pré-termo: mecanismos básicos de ativação via receptores semelhantes ao Toll 4 (TLR-4) em diferentes células apresentadoras de antígenos.

3. Desconfortos e riscos esperados: Não ocasionará desconforto ao recém-nascido, pois o sangue será coletado da veia do cordão umbilical após a retirada.

4. Benefícios que poderão ser obtidos: Trata-se de um estudo experimental testando a hipótese de que a susceptibilidade dos neonatos humanos às infecções por bactérias Gram-negativas está relacionada, em parte, à imaturidade funcional da resposta imune inata mediada pelo TLR-4. Somente no final do estudo poderemos concluir a presença de algum benefício. 


\section{II - OBSERVAÇÃO:}

$>$ A senhora terá acesso, a qualquer tempo, às informações sobre procedimentos, riscos e benefícios relacionados à pesquisa, inclusive para diminuir eventuais dúvidas.

$>$ A senhora terá liberdade de retirar seu consentimento a qualquer momento e de deixar de participar do estudo, sem que isto traga prejuízo à continuidade da assistência.

$>$ A senhora terá total confidencialidade, sigilo e privacidade dos dados deste estudo.

> Disponibilidade de assistência, por eventuais danos à saúde, decorrentes da pesquisa;

> Se for detectado, algum problema de saúde previamente ao início da pesquisa, a senhora será encaminhada ao Sistema Único de Saúde (SUS) para o tratamento.

> Se houver intercorrência de saúde decorrente da pesquisa, a senhora será atendida no HU/USP segundo o critério de assistência do mesmo (hospital de atendimento secundário). Se houver necessidade de atendimento de maior complexidade, a encaminharemos ao SUS.

$>$ A duração prevista da pesquisa é de quatro (4) anos.

III - INFORMAÇÕES DE NOMES, ENDEREÇOS E TELEFONES DOS RESPONSÁVEIS PELO ACOMPANHAMENTO DA PESQUiSA, PARA CONTATO EM CASO DE INTERCORRÊNCIAS CLÍNICAS E REAÇÕES ADVERSAS:

\section{NOME DOS PESQUISADORES ENVOLVIDOS:}

\section{Pesquisadora executante: Ana Lúcia Silveira Lessa Marques}

Dra.

Dr.

Pesquisadora responsável: Dra. Patricia Palmeira

CEP-HU: Endereço: Av. Prof. Lineu Prestes, 2565 - Cidade Universitária - CEP: 05508-900 - São Paulo - SP - Telefones: 3039-9457 ou 3039-9479 - E-mail: cep@ hu.usp.br.

\section{IV - INFORMAÇÕES DO PACIENTE:}

NOME DO PACIENTE.:

DOCUMENTO DE IDENTIDADE $\mathrm{N}^{\circ}$ : SEXO : $\mathrm{M}^{\sim} \mathrm{F}^{\sim}$

DATA NASCIMENTO: .........................

ENDEREÇO $\mathrm{N}^{\mathrm{o}}$ APTO:

BAIRRO: CIDADE:

CEP: TELEFONE: DDD( ...)............ 
V - ENCERRAMENTO DO TERMO DE CONSENTIMENTO LIVRE E ESCLARECIDO

"DECLARO QUE, APÓS CONVENIENTEMENTE ESCLARECIDO PELO PESQUISADOR E TER ENTENDIDO O QUE ME FOI EXPLICADO, CONSINTO EM PARTICIPAR DO PRESENTE PROJETO DE PESQUISA."

SÃO PAULO, DE DE $200 \ldots$. 
APÊNDICE C - Phenotypic Differences in Leucocyte Populations among Healthy Preterm and Full-Term Newborns 


\title{
Phenotypic Differences in Leucocyte Populations among Healthy Preterm and Full-Term Newborns
}

\author{
C. Quinello*†, A. L. Silveira-Lessa†t, M. E. J. R. Ceccon*, M. A. Cianciarullo*, \\ M. Carneiro-Sampaio*† \& P. Palmeira*†
}

*Department of Pediatrics, Faculdade de Medicina da Universidade de São Paulo, São Paulo, Brazil; †Laboratory of Medical Investigation (LIM-36), Instituto da Criança, Hospital das Clínicas, São Paulo, Brazil; and \$Department of Parasitology, Instituto de Ciências Biomédicas da Universidade de São Paulo, São Paulo, Brazil

Received 13 December 2013; Accepted in revised form 7 April 2014

Correspondence to: C. Quinello, LIM-36, Department of Pediatrics, Hospital das Clínicas, Faculdade de Medicina, Universidade de São Paulo, Av. Dr. Enéas Carvalho de Aguiar, 647 Instituto da Criança - $5^{\circ}$ andar, CEP: 05403-900, São Paulo, SP, Brazil. E-mail:caquinello @hotmail.com

\begin{abstract}
The immune system of neonates has been considered functionally immature, and due to their high susceptibility to infections, the aim of this study was to analyse the phenotypic differences in leucocyte populations in healthy preterm and fullterm newborns. We evaluated the absolute numbers and frequencies of dendritic cells (DCs) and DC subsets, monocytes and T and B lymphocytes and subsets in the cord blood of healthy moderate and very preterm (Group 1), late preterm (Group 2) and full-term (Group 3) newborns and in healthy adults, as controls, by flow cytometry. The analyses revealed statistically higher absolute cell numbers in neonates compared with adults due to the characteristic leucocytosis of neonates. We observed a lower frequency of $\mathrm{CD} 80^{+}$myeloid and plasmacytoid DCs in Group 1 and reduced expression of TLR- 4 on myeloid DCs in all neonates compared with adults. TLR $-2^{+}$monocytes were reduced in Group 1 compared with Groups 2 and 3, and TLR- $4^{+}$monocytes were reduced in Groups 1 and 2 compared with Group 3. The frequencies and numbers of naive $\mathrm{CD}^{+} \mathrm{T}$ and $\mathrm{CD} 19^{+} \mathrm{B}$ cells were higher in the three groups of neonates compared with adults, while $\mathrm{CD}^{+}$effector and effector memory $\mathrm{T}$ cells and $\mathrm{CD} 19^{+}$memory $\mathrm{B}$ cells were elevated in adults compared with neonates, as expected. Our study provides reference values for leucocytes in cord blood from term and preterm newborns, which may facilitate the identification of immunological deficiencies in protection against extracellular pathogens.
\end{abstract}

\section{Introduction}

At birth, neonates have an increased susceptibility to infectious agents due to the functional immaturity of their immune systems. Some immune functions in neonates are particularly immature, while other aspects of neonates' immune systems are functional at birth, even in extremely preterm infants. Innate immune impairment in the neonate is marked by quantitative and qualitative neutrophil defects, including a small storage pool of neutrophils at birth and reduced complement levels. Monocytes/macrophages are functionally adequate in neonates but are limited in their chemotactic responses. The lack of adaptive immunity in neonates is reflected in the decreased number of memory $\mathrm{T}$ cells expressing the $\mathrm{CD} 45 \mathrm{RO}$ isoform and the increased number of naive $T$ cells expressing the CD45RA isoform compared with adults as well as low production of immunoglobulin (Ig) G, $\operatorname{IgA}$ and $\operatorname{IgE}$ by newborn B cells [1-7].

The immune system of preterm neonates is thought to be less developed at birth than term ones, but very little is known about the actual size of lymphocyte subpopulations in preterm neonates or the maturation of these subpopulations during the first months after a premature birth [8]. Studies of leucocytes from preterm newborns have been limited, and there are little data available concerning the development and function of the innate immune system during gestational ageing [9]. Preterm infants are at a heightened risk of acquisition of recurrent bacterial infections during their first weeks of life due to frequent exposure to micro-organisms, frequent invasive procedures such as catheterization and intravascular or assisted ventilation, in addition to the immaturity of the immune system [10].

Immunophenotyping of blood cell populations to identify these cells and their expression of pattern recognition and activation molecules is an important tool in the diagnosis and follow-up of children with immunodeficiencies and other immune disorders. Correct interpretation of the results obtained from patients requires knowledge of the normal development of the immune system during the first years of life. Most studies on the human immune 
system have been conducted with adults, and many questions about lymphocyte development in children have not been answered. This deficiency is due to the difficulty in obtaining blood from babies in large quantities, thus representing a practical problem. Therefore, most studies of newborns have been conducted using neonatal umbilical cord blood, which can be easily obtained in larger quantities [11].

Preterm infants born before 28 weeks' gestation are at greater risk of invasive bacterial infections [12], but current studies indicate that late preterm infants also have a significantly higher rate of complications of prematurity and experience more difficulties with feeding, hypoglycaemia, jaundice, temperature instability, apnoea and respiratory distress [13]. This suggests that the last month of gestation is a critical culminating period for the maturation of the immune system [13-15].

Due to the high incidence of extracellular bacterial infections in neonates, it is important to investigate the neonatal ability to combat these pathogens. In this study, we used flow cytometry to evaluate monocyte and dendritic cell populations and their pattern recognition and activation markers as well as helper $\mathrm{T}$ and $\mathrm{B}$ lymphocytes and their subpopulations in umbilical cord blood from healthy preterm and full-term newborns and, as controls, in peripheral blood from healthy adults.

\section{Materials and methods}

Study population and blood samples. We performed a crosssectional descriptive study using umbilical cord blood from healthy adequate-for-gestational-age preterm and full-term newborns. Newborns $(n=56)$ were classified into three groups according to their post-menstrual age at birth: newborns born at $30-33 \%$ gestation weeks were classified as moderate and very preterm newborns (Group 1, $n=13$ ); newborns born at $34-36 \%$ gestation weeks were classified as late preterm newborns (Group 2, $n=21$ ); and newborns born at 37-41 gestation weeks were classified as full-term newborns (Group 3, $n=22$ ) [16]. Gestational age (GA) was calculated based on last menstrual period or ultrasound measurement of foetal length in the first trimester. Exclusion criteria were genetic syndromes, Apgar score of $<5$ at $5 \mathrm{~min}$, clinical or pathological evidence of chorioamnionitis or clinical and laboratory signs of infection (elevated infection markers such as C-reactive protein, IL-8 and IL-6; rupture of membranes for more than $18 \mathrm{~h}$; and confirmed early-onset sepsis).

There were two sets of twins within both preterm groups. The subset data were examined for concordance and discordance in the twins. The range of subset percentages in the twins was similar to that of the singleton population.

Neonatal cord blood was collected from the foetal side of the placenta immediately after delivery by umbilical cord venipuncture after clamping in EDTA-coated tubes and in special clot activator tubes for serum separation and cytokine measurement. Blood in EDTA tubes was maintained at room temperature and processed within $24 \mathrm{~h}$ of collection.

The cytokines IL-8 and IL-6 were measured with a cytometric bead array (Becton Dickinson BD Biosciences, San Jose, CA, USA) using sera from cord blood from the three groups of neonates.

Peripheral blood was collected from healthy adult volunteers as controls $(n=39)$. The age range of the adults is 20 to 40 years. They were selected from the laboratory's group and were chosen by the absence of clinical signs of infection.

The neonates were recruited from the Obstetric Center, University Hospital, University of São Paulo, and the Obstetric Center of the Central Institute of the Hospital das Clínicas. The study was approved by the Research and Ethics Committee of the Department of Pediatrics of São Paulo University School of Medicine and by the Ethics Committee for the Analysis of Projects and Research of the Hospital das Clínicas (0101/10). Informed consent was obtained from each participant.

Immunophenotyping by flow cytometry. The number of total blood leucocytes from the umbilical cord blood and peripheral blood samples was determined with an automatic counter (Abbott Cell-Dyn CD-1700 Hematology Analyzer, Abbott Diagnostics, Abbott Park, IL, USA). To analyse cell populations, $1 \times 10^{6}$ leucocytes were placed in a tube and subjected to two 20-min erythrocyte lysis steps using BD Pharm Lyse ${ }^{\mathrm{TM}}$ (BD Biosciences). After centrifugation and washing with staining buffer (phosphatebuffered saline with $1 \%$ foetal calf serum and $0.1 \%$ sodium azide), the cells were stained with fluorochromeconjugated monoclonal antibodies against each cell population under study for $30 \mathrm{~min}$. After washing, the cells were resuspended in staining buffer and immediately analysed to prevent the loss of fluorescence. Data were acquired with a BD LSRII Flow Cytometer ${ }^{\text {TM }}$ (BD Biosciences) with FACSDiva software (Becton Dickinson), and the analysis was conducted using FlowJo software (Tree Star, Ashland, OR, USA). Data are represented as the means of absolute numbers or frequencies.

The same fluorochromes were used for all experiments: fluorescein isothiocyanate (FITC) or Alexa Fluor ${ }^{\mathrm{TM}} 488$; phycoerythrin (PE); phycoerythrin-cyanine 5 (PE-Cy5) or peridinin-chlorophyll-protein-cyanine 5.5 (PerCP-Cy5.5); phycoerythrin-cyanine 7 (PE-Cy7); allophycocyanin (APC) or Alexa ${ }^{\mathrm{TM}}$ 647; allophycocyanin-cyanine 7 (APC-Cy7); Pacific blue ${ }^{\mathrm{TM}}$ or V450 or Brilliant Violet $421^{\mathrm{TM}}$ (BioLegend, San Diego, CA, USA); AmCyan or V500, all from BD Biosciences unless otherwise stated.

Dendritic cells. Dendritic cells were defined as lineage cocktail $\left(\mathrm{Lin}^{-}\right)$negative and (HLA-DR ${ }^{+}$) positive according to Koumbi et al. [17] and Shin et al. [18], and myeloid 
DC populations (mDC: $\mathrm{Lin}^{-} \mathrm{HLA}-\mathrm{DR}^{+} / \mathrm{CD} 11 \mathrm{c}^{+}$) and plasmacytoid DC populations (pDC: Lin $^{-} \mathrm{HLA}_{-} \mathrm{DR}^{+} /$ $\mathrm{CD} 123 \mathrm{c}^{+}$) were characterized as described by Sorg et al. [19] and Schreibelt et al. [20]. Within each subpopulation, the dendritic cell pattern recognition, maturation and activation markers were analysed using CD1a, CD80, CD86, TLR-2 and TLR-4. The results were expressed as the percentage of total DCs of all nucleated cells. Absolute numbers of DCs were calculated from complete blood leucocyte counts. Subpopulations of mDCs and pDCs were expressed as percentages and absolute numbers of total DCs (Fig. 1A, B).

Monocytes. To analyse monocyte populations, a $\mathrm{P} 1$ gate on $\mathrm{CD} 14^{+} / \mathrm{HLA}_{-} \mathrm{DR}^{+}$cells was established. The expression levels of the costimulatory molecules CD80, CD86 and CD40, and the pattern recognition receptors TLR-2 and TLR-4 were analysed on cells within this P1 gate (Fig. 1C).

$T$ lymphocytes. $\mathrm{T}$ cell subsets were identified based on the expression of CD45RA and CCR7. Characterization of the $\mathrm{CD} 4^{+} \mathrm{T}$ cell compartment was performed using combinations of markers gating on $\mathrm{CD}^{+} / \mathrm{CD}^{+}$cells within the total lymphocyte population. Within the $\mathrm{CD} 3^{+} / \mathrm{CD} 4^{+}$helper $\mathrm{T}$ lymphocyte gate, $\mathrm{CD} 4^{+} / \mathrm{CD} 27^{+} / \mathrm{CD} 45 \mathrm{RA}^{+} / \mathrm{CCR} 7^{+} /$ $\mathrm{CD}_{2} \mathrm{~L}^{+}$cells were naive $\mathrm{T}$ lymphocytes; $\mathrm{CD}^{+} /$ CD62L $\mathrm{L}^{\text {low }} / \mathrm{CD}^{+} 9^{+}$cells were effector $\mathrm{T}$ lymphocytes; $\mathrm{CD} 4^{+} / \mathrm{CD} 27^{+} / \mathrm{CD} 45 \mathrm{RA}^{-} / \mathrm{CCR} 7^{+}$cells were central memory $\mathrm{T}$ lymphocytes; and $\mathrm{CD}^{+} / \mathrm{CD} 27^{+} / \mathrm{CD} 45 \mathrm{RA}^{-} / \mathrm{CCR} 7^{-}$ cells were effector memory T lymphocytes (Fig. 1D, E, F, G).

$B$ lymphocytes. B cells were identified as $\mathrm{CD} 9^{+}$cells within the total lymphocyte population. Definitions of $\mathrm{B}$ cell subsets were performed using the following markers: $\mathrm{CD} 19^{+} / \mathrm{CD} 27^{-}$cells as naive B lymphocytes; $\mathrm{CD} 19^{+} /$ $\mathrm{CD} 27^{+}$cells as memory B lymphocytes; and $\mathrm{CD} 19^{+} /$ $\mathrm{CD} 69^{+} / \mathrm{CD} 40^{+}$cells as activated B lymphocytes. Within the $\mathrm{CD} 19^{+} \mathrm{B}$ cell population, TLR-2 and TLR-4 expressions were also analysed (Fig. 1H, I).

Statistical analysis. Statistical analyses were conducted using MedCalc 12.7.0 (MedCalc Software, Ostend, Belgium). Kruskal-Wallis nonparametric statistical test followed by Dunn's post hoc test for multiple comparisons was performed to compare groups that were not normally distributed. A significance threshold of 0.05 was used for all tests unless otherwise stated.

\section{Results}

\section{Characteristics of preterm and term newborns}

A total of 56 neonates, 13 moderate and very preterm neonates born before 34 gestation weeks, 21 late preterm neonates born between $34-36 \%$ gestation weeks and 22 full-term neonates born after 37 gestation weeks were enrolled in the study as shown in Table 1. These groups were divided according to the classification proposed by Engle [21]. Leucocyte subset data from these neonates were
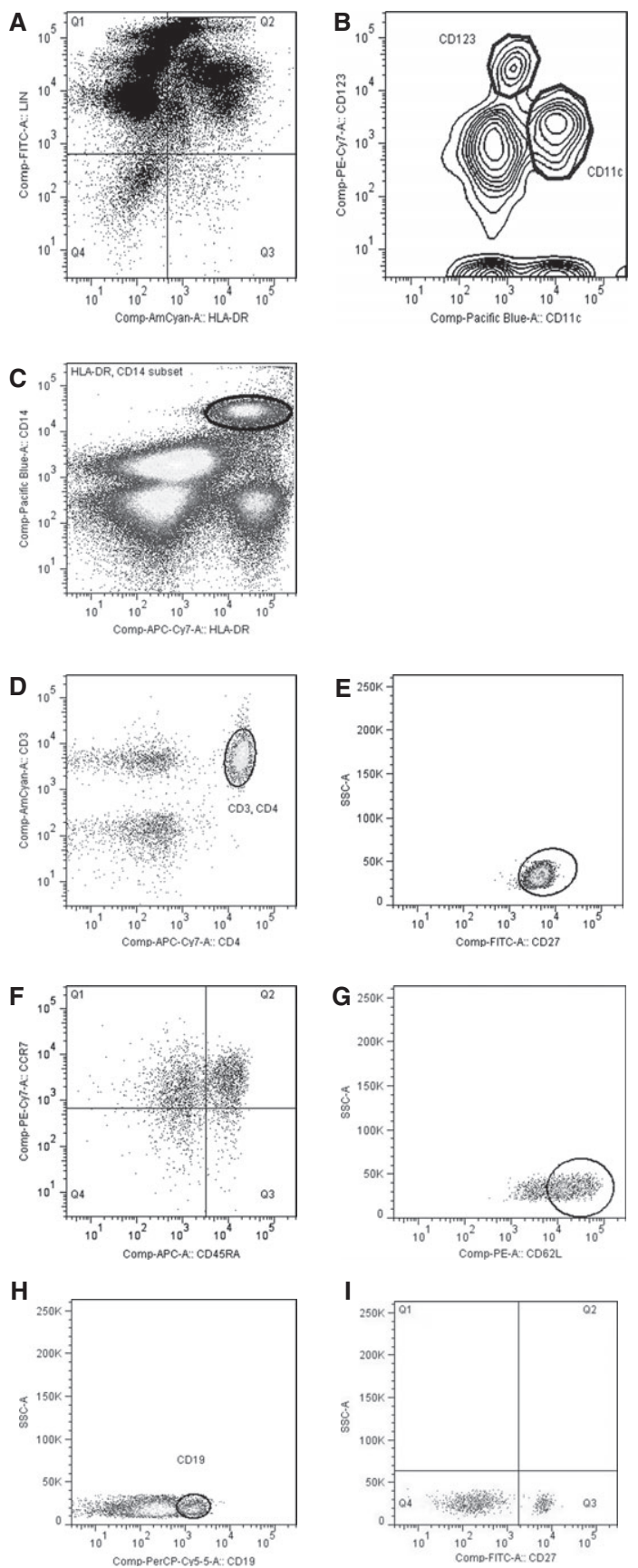

Figure 1 Representative phenotypic analysis of leucocyte subsets by flow cytometry. (A) Lin-negative but HLA-DR-positive dendritic cells were gated in Q3; (B) myeloid dendritic cells (mDCs) were identified as CD11c positive and CD123 negative, and plasmacytoid dendritic cells (pDCs) were identified as CD11c negative and CD123 positive within Lin $^{-}$HLA-DR ${ }^{+}$ cells; (C) monocytes were identified as CD14-positive and HLA-DRpositive cells; (D) CD4 T cells were identified by gating on CD3CD $4{ }^{\text {bright }}$ and within the total lymphocyte population; (E-F) $\mathrm{CD}^{+} \mathrm{T}$ cell subsets were identified within the $\mathrm{CD} 27^{+}$gate and then based on the expression of CD45RA and CCR7, as shown. Q1: CD4 ${ }^{+}$central memory T cells; Q4: $\mathrm{CD}^{+}{ }^{+}$effector memory $\mathrm{T}$ cells; and $\mathrm{Q} 2: \mathrm{CD}^{+}$naive $\mathrm{T}$ cells were further analysed within the $\mathrm{CD} 62 \mathrm{~L}^{+}$gate $(\mathrm{G}) ;(\mathrm{H}) \mathrm{B}$ cells were identified by gating on CD19-positive cells and within the total lymphocyte population; (I) naïve and memory $\mathrm{B}$ cell subsets were identified based on the expression of

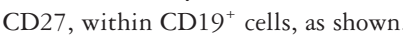


Table 1 Demographic characteristics and total leucocyte counts of study subjects.

\begin{tabular}{|c|c|c|c|c|c|c|}
\hline \multirow[b]{2}{*}{ Characteristics } & \multirow{2}{*}{$\begin{array}{l}\text { Group } 1(\mathrm{G} 1) \\
(N=13)\end{array}$} & \multirow{2}{*}{$\begin{array}{l}\text { Group } 2 \text { (G2) } \\
(N=21)\end{array}$} & \multirow{2}{*}{$\begin{array}{l}\text { Group } 3 \text { (G3) } \\
(N=22)\end{array}$} & \multicolumn{3}{|l|}{$P$ value } \\
\hline & & & & $\mathrm{G} 1 \times \mathrm{G} 2$ & $\mathrm{G} 1 \times \mathrm{G} 3$ & $\mathrm{G} 2 \times \mathrm{G} 3$ \\
\hline Male/female ${ }^{a}$ & $9(69.2) / 4(30.8)$ & $13(61.9) / 8(38.1)$ & $13(59.1) / 9(40.9)$ & - & - & - \\
\hline Birth weight $(g)^{\mathrm{b}}$ & $1606 \pm 294.3$ & $2166 \pm 454$ & $3317 \pm 431.4$ & $P<0.001$ & $P<0.0001$ & $P<0.0001$ \\
\hline Gestational age (weeks) ${ }^{\mathrm{b}}$ & $32 \pm 12 / 7$ & $351_{7}^{1} \pm 06 / 7$ & $39^{1 / 7} \pm 1 \frac{1}{7}$ & $P<0.001$ & $P<0.0001$ & $P<0.0001$ \\
\hline Apgar at $1 \min ^{\mathrm{b}}$ & $7 \pm 2$ & $8 \pm 2$ & $9 \pm 1$ & - & $P<0.001$ & $P<0.05$ \\
\hline Apgar at $5 \min ^{\mathrm{b}}$ & $9 \pm 1$ & $9 \pm 1$ & $10 \pm 1$ & - & $P<0.001$ & $P<0.05$ \\
\hline Delivery $^{a}$ NSVD /C-section & $3(23.1) / 10(76.9)$ & $6(28.6) / 15(71.4)$ & $11(50.0) / 11(50.0)$ & - & - & - \\
\hline IL- $8^{\mathrm{b}}$ & $68.7 \pm 104.7$ & $142.5 \pm 402.4$ & $276.7 \pm 568.4$ & - & - & - \\
\hline IL- $6^{\mathrm{b}}$ & $32.7 \pm 79.9$ & $25.2 \pm 56.2$ & $14.0 \pm 40.8$ & - & - & - \\
\hline Leucocyte numbers $\left(10^{3} / \mu \mathrm{l}\right)^{\mathrm{b}}$ & $9.1 \pm 4.1$ & $10.4 \pm 3.9$ & $14.8 \pm 5.3$ & - & $P<0.05$ & $P<0.05$ \\
\hline
\end{tabular}

NSVD, normal spontaneous vaginal delivery.

${ }^{\mathrm{a}}$ Frequency (percentage).

${ }^{\mathrm{b}}$ Mean \pm standard deviation.

compared with the leucocyte subset data from 39 adult controls. All 56 newborns included in this study were born without signs of infection; they were excluded if any indication of a pathologic background in the mother's clinical history was detected. The C-reactive protein, IL-8 and IL-6 levels in the newborns' sera also indicated that they were healthy.

Given the increased risk of infection in preterm infants and the pathophysiological role of cytokines as mediators of infection, measurement of neonatal cytokine levels may provide an earlier biomarker for the diagnosis of infection than downstream markers such as $\mathrm{C}$-reactive protein and absolute changes in white blood cell counts. The concentration of IL- 8 depended on the mode of delivery and was higher in neonates delivered vaginally than those delivered by elective caesarean section, which resulted in slightly higher, although not statistically significant, IL-8 levels in Group 3 compared with the other groups. IL-6 concentrations were low in all newborn samples and were statistically equivalent between groups.

Statistical analysis demonstrated that newborns from Group 3 had higher leucocyte numbers than the other groups $(P<0.05)$ (Table 1$)$ and that adults had significantly lower leucocyte numbers than the three groups of newborns $\left(\right.$ mean $\left.=6.6 \times 10^{3} / \mu \mathrm{l}\right)(P<0.05)$.

We determined the absolute leucocyte subpopulation counts in preterm and full-term infants by 8-colour flow cytometry. We compared these data with data obtained from healthy adults.

\section{Dendritic cell subsets}

The data in Table 2 and Fig. 2 show specific comparisons among full-term neonates and preterm neonates after determination of statistical significance across these study groups using the Kruskal-Wallis test as described elsewhere. The frequencies and absolute numbers of dendritic cells among all nucleated cells were equivalent across neonatal groups. Group 3 had lower percentages of mDCs and $\mathrm{pDCs}$ than both preterm groups. The numbers of $\mathrm{mDCs}$ and $\mathrm{pDCs}$ did not differ among the neonate groups. Myeloid and plasmacytoid DCs expressing the activation markers CD80 and CD86 were also present at the same frequencies among neonatal groups, with the exception of Group 1, which displayed a reduced frequency of $\mathrm{CD}^{+} 0^{+}$ cells in both DC subsets compared with Group 3. No differences in frequencies were detected among the groups with regard to immature $\mathrm{mDCs}$ and $\mathrm{pDCs}$ expressing CD1a. Group 1 had significantly less absolute numbers of $\mathrm{CD} 0^{+} \mathrm{mDC}$ and $\mathrm{CD} 80^{+}$pDCs compared with Groups 2 and 3 . These results were influenced by the low frequencies of these cell subsets in neonates from Group 1.

The percentages of TLR $-2^{+}$mDCs gradually increased across the neonatal groups, but no significant differences were detected among them. All newborns had lower frequencies of TLR $-4^{+}$mDCs than adults, while TLR $-4^{+}$ pDCs were present in similar percentages in neonates and adults.

The majority of the analyses revealed statistically higher absolute numbers of DCs and DC subsets in neonates compared with adults, as was also observed for TLR-2 and TLR-4 expressions in both DC subsets, but these results reflected the higher numbers of leucocytes in the umbilical cord blood.

\section{Monocytes}

The percentages of monocytes were similar among all neonate groups and the adults with the exception of Group 2, which had a higher frequency of these cells than adults (Fig. 3). However, the absolute counts revealed a lower number of these cells in Group 1 compared with the other neonates (Table 3). The analyses of the frequency of activation markers CD80 and CD86 on the surface of 


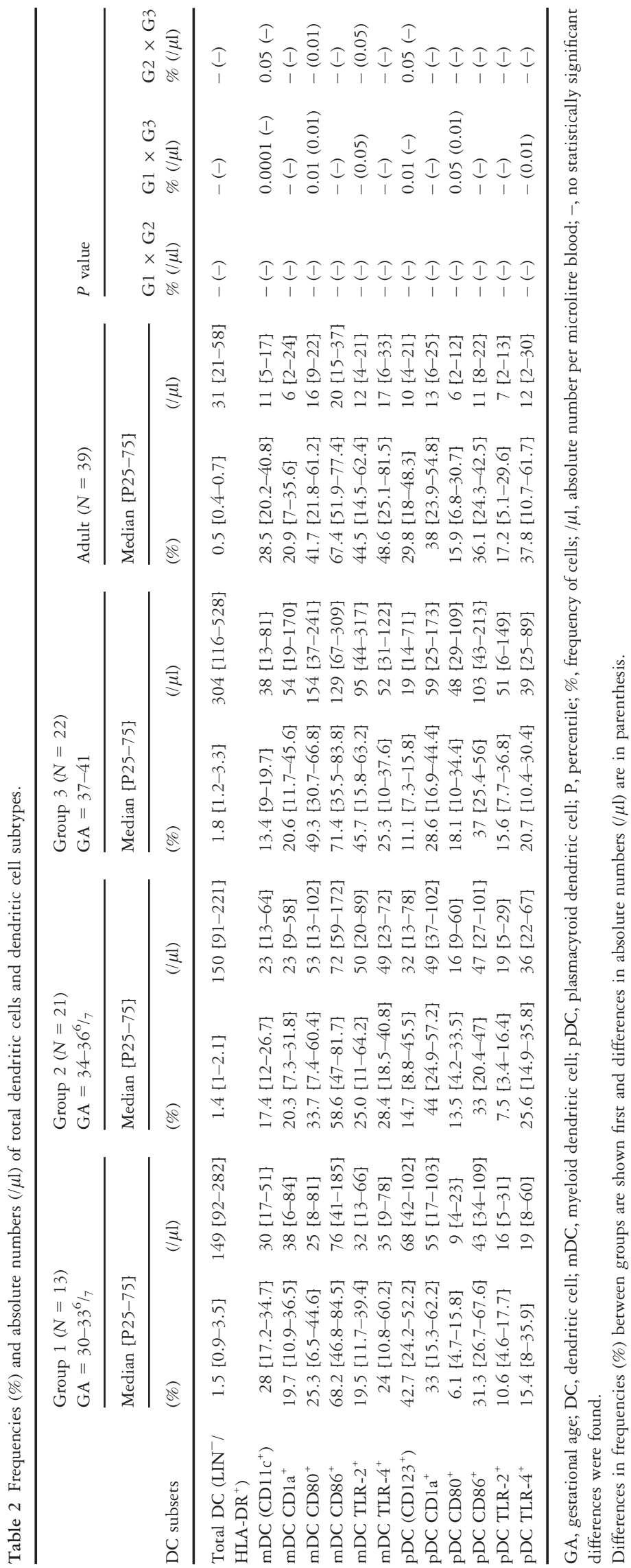



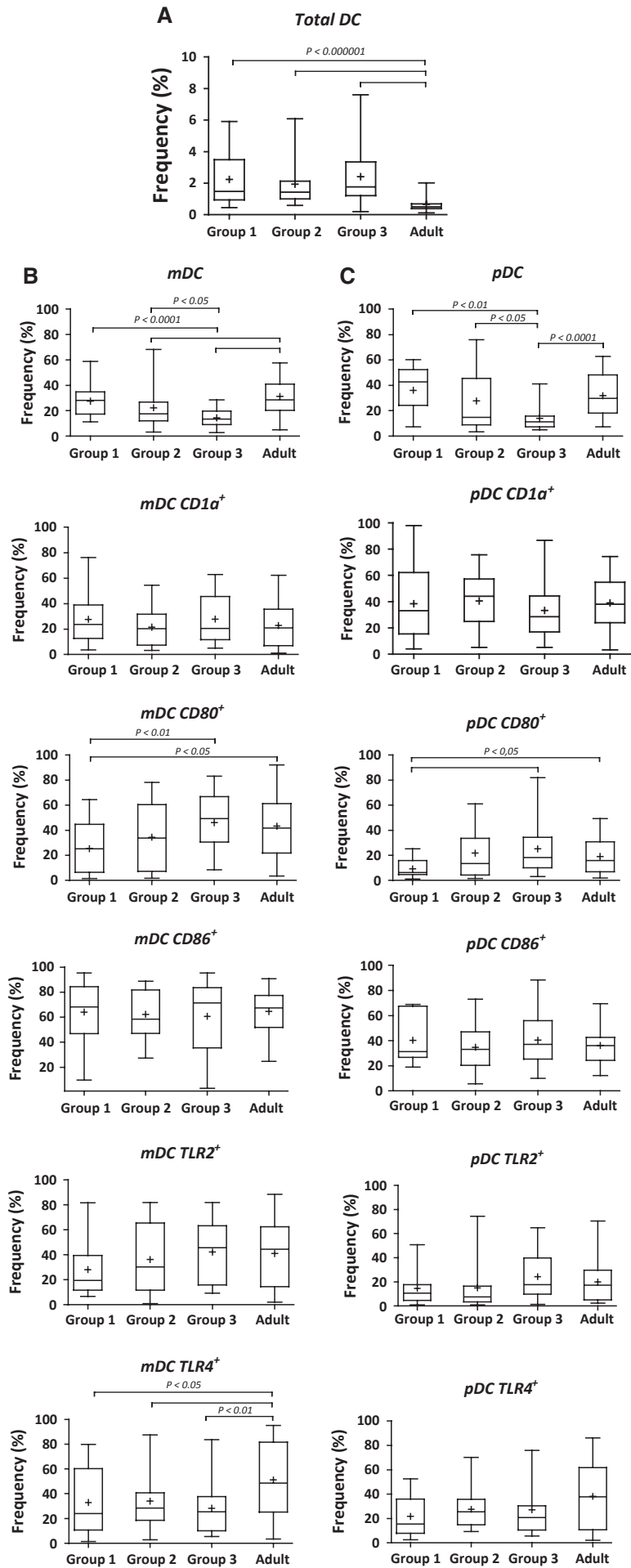

Figure 2 Frequencies of dendritic cells and their subsets in cord blood. (A) Total dendritic cells; (B) myeloid dendritic cell (mDC); and (C) plasmacytoid dendritic cell (pDC); immature $\left(\mathrm{CDla}^{+}\right)$; mDCs or $\mathrm{pDCs}$ expressing activation markers CD80 and CD86; and TLR-2 and TLR- 4 in cord blood from preterm (Groups 1 and 2) and term (Group 3) newborns and in adult blood, as controls. Box plots: black crosses are the mean, black horizontal lines are medians, the solid lines of the box represent the 75th and 25th percentiles, and the short lines outside the top and the base of the box represent the highest and the lowest values, respectively. monocytes revealed no significant differences with the exception of Group 2, which showed a higher frequency of $\mathrm{CD} 86^{+}$monocytes compared with Group $3(P<0.01)$. The frequencies of TLR-2- and TLR-4-expressing monocytes were similar among all groups. In addition, Group 1 had a lower number of TLR-2 ${ }^{+}$monocytes compared with other newborns, while Group 3 had a higher number of TLR $-4^{+}$monocytes compared with both preterm newborn groups.

\section{T Lymphocyte subsets}

The analysis of total lymphocytes revealed a lower frequency of this population in term newborns from Group 3 compared with both preterm groups. Based on the expression of CD45RA, CCR7 and CD62L, the $\mathrm{CD}^{+}{ }^{+} \mathrm{T}$ cell compartment was divided into naive, central memory and effector memory $\mathrm{T}$ cells. The data in Table 4 and Fig. 4 show that the percentages of $\mathrm{CD} 3^{+} \mathrm{CD} 4^{+}$helper $\mathrm{T}$ cells varied across the neonatal groups but were not significantly different, and the same was found for absolute numbers.

Study of the central memory, effector memory and naive subsets of $\mathrm{CD}^{+} \mathrm{T}$ cells revealed no differences among neonates, with the exception of the higher number of naive $\mathrm{T}$ cells found in Group 2 compared with Group 3. As expected, higher percentages and numbers of naive $T$ cells and strikingly lower frequencies and numbers of effector memory $\mathrm{T}$ cells and effector $\mathrm{T}$ cells were observed in all newborns compared with adults.

\section{B Lymphocyte subsets}

As shown in Table 5 and Fig. 5, the percentages and numbers of blood $\mathrm{CD} 19^{+} \mathrm{B}$ lymphocytes were equivalent among all neonatal groups. Naïe B cell percentages and numbers were higher in neonates than in adults, indicating that these cells constituted the largest peripheral B cell subset in preterm and full-term neonates, and by contrast, full-term and preterm groups had a strikingly lower percentage of memory B cells compared with adults, as expected. The activated B cell subset was present in similarly low percentages in newborns and adults. TLR-2 and TLR-4 expressions on B lymphocytes were insignificant (data not shown).

\section{Discussion}

Previous studies have compared leucocyte subsets from full-term neonates with adults, but these studies rarely include samples from preterm newborns. Generally, the composition of circulating white blood cells numerically differs among neonates of different gestational ages, likely reflecting dynamic developmental phases [15]. The proportions of both lymphoid and myeloid cells are higher in the peripheral blood of a healthy-term neonate than a 
Figure 3 Frequencies of monocytes in cord blood. Total monocytes and monocytes expressing activation markers CD80 and CD86 and TLR-2 and TLR-4 in cord blood from preterm (Groups 1 and 2) and term (Group 3) newborns and in adult blood, as controls. Box plots: black crosses are the mean, black horizontal lines are medians, the solid lines of the box represent the 75th and 25th percentiles, and the short lines outside the top and the base of the box represent the highest and the lowest values, respectively.

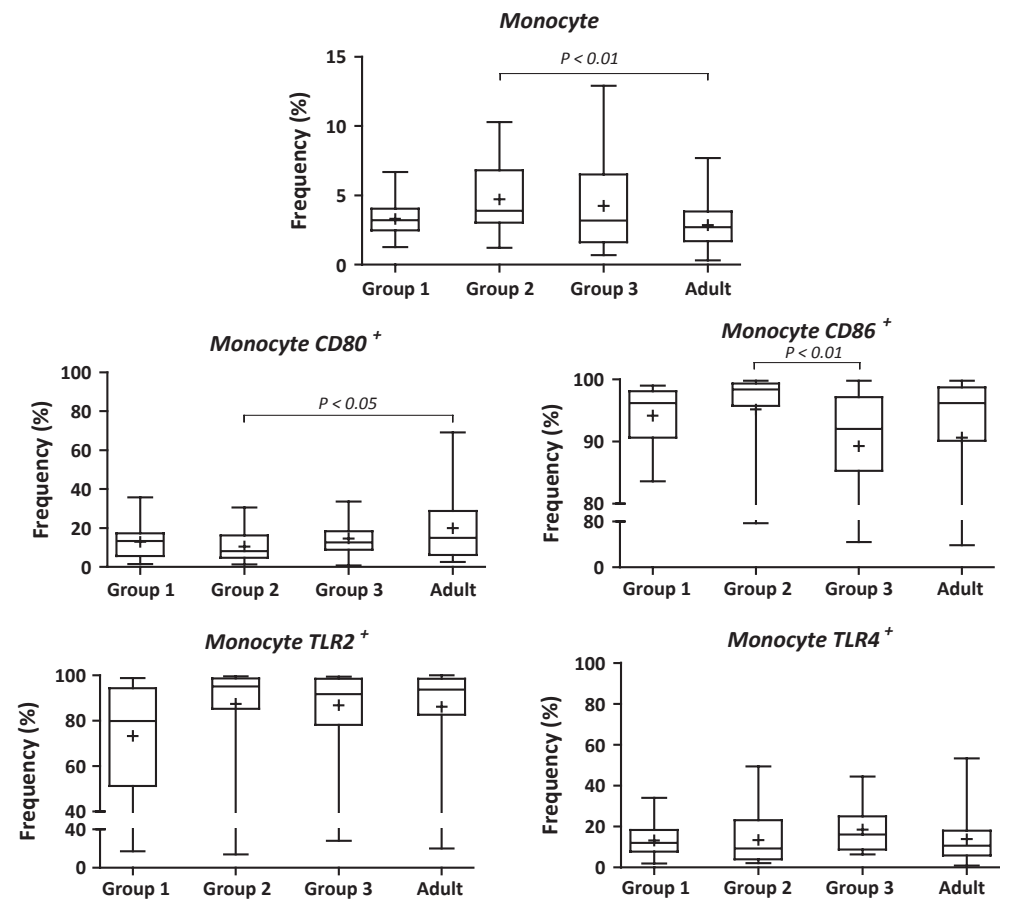

preterm [22-25]. Furthermore, it is difficult to compare previous data because of differences in methodology. Both relative and absolute counts have been used to illustrate the changes in leucocyte [26-28]. However, it is important to compare absolute counts to assess the actual size of a leucocyte subpopulation [29]. In the present work, we consistently observed differences in absolute numbers of different leucocyte populations among neonates and adults, but these results reflected the higher number of circulating leucocytes found in the three groups of neonates.

The induction of different types of innate and adaptive immune responses based on the nature of the antigens and the environmental context is crucial to cope with a variety of pathogens and to concurrently avoid pathological reactions to self-antigens. Several studies have shown that the diverse immune responses are critically controlled by dendritic cells (DCs). DCs are widely distributed, potent antigen-presenting cells (APCs) that are unique based on their prominent role in the activation, polarization and regulation of adaptive immune responses [19, 30-32].

Depending on their developmental origin, cytokine activation, surface antigens and functional capacity, DCs can be subdivided into two major distinct populations: myeloid and lymphoid/plasmacytoid DCs [33]. Myeloid DCs may be further split into $\mathrm{CD}_{1} \mathrm{c}^{+}$and $\mathrm{CD} 141^{+}$ fractions. $\mathrm{CD}_{1} \mathrm{c}^{+} \mathrm{mDCs}$ are the major population of human mDCs in blood, tissues and lymphoid organs and are good stimulators of naive CD $4 \mathrm{~T}$ cells. mDCs secrete tumour necrosis factor- $\alpha$ (TNF- $\alpha$ ), IL-8, IL-10 and high levels of IL-12, and a small amount of IL-23 can be detected after a range of stimuli. This implies a dual role in $\mathrm{T}$ helper type 1 (Th1) and Th17 sensitization and highlights the plasticity of DCs in different contexts. Plasmacytoid DCs are distinguished by expression of CD123, CD303 and CD304, and their propensity to release abundant amounts of type I interferons (IFNs) in response to viruses was one of the first specialized DC functions to be described. It has been demonstrated that freshly isolated blood pDCs do not prime naive $\mathrm{T}$ cells efficiently and appear less mature than mDCs until activated, in agreement with our findings that showed higher frequencies of immature $\mathrm{CDla}^{+} \mathrm{pDC}$ than $\mathrm{mDC}$, but no differences across the study groups. Nevertheless, the ability of pDCs to polarize CD4 responses towards Th1 or Th2 is variable and may be context dependent $[33,34]$. In the present work, although we observed significantly higher relative and absolute numbers of total DCs in preterm and full-term newborns compared with adults, the latter had an increased frequency of mDCs compared with newborns, which could contribute to a more efficient activation of $\mathrm{T}$ cell response.

TLRs play a crucial role in the induction of adaptive immunity as well as innate immunity. DC subsets recognize different microbial pathogens by expressing distinct TLRs on their surface and induce different types of innate and adaptive immune responses, depending on environmental factors [35-37]. Dendritic cells from cord blood normally express TLR-2 and TLR-4 [32, 38]. Expression levels of TLR-2 and TLR-4 were previously shown to be normal on neonatal mDCs, in contrast to the lower levels of expression of these molecules on 


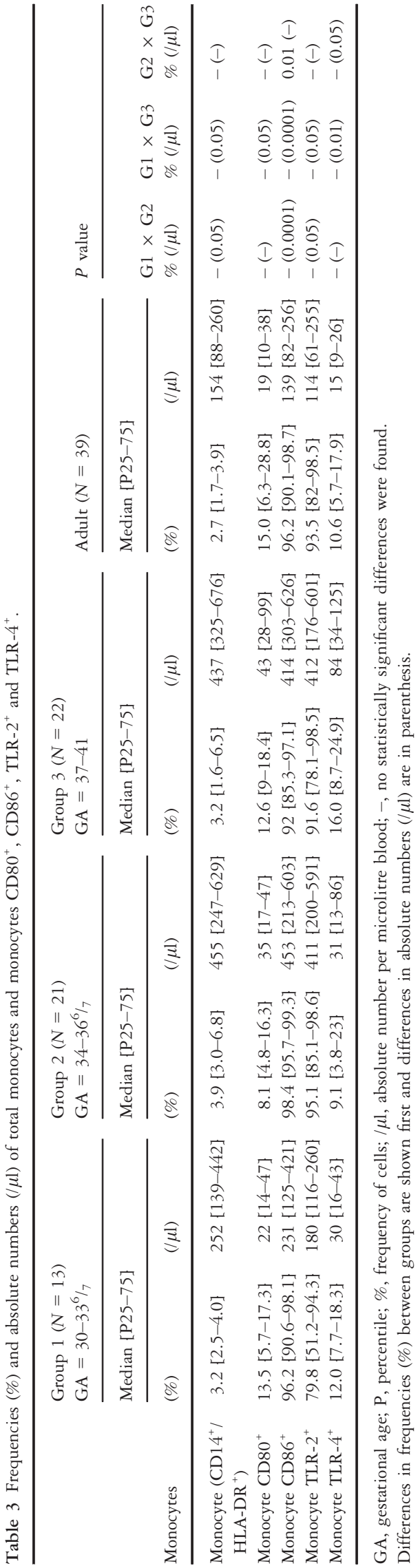

neonatal monocytes [39]. These results are in agreement with our data, at least with regard to TLR-4. We observed the same expression pattern on pDCs as we did not observe significant differences in TLR expression on pDCs among neonates and adults, although we observed increasing TLR-2 expression on $\mathrm{mDCs}$ and $\mathrm{pDCs}$ according to gestational age. The lower expression of TLR- 4 on neonatal mDCs found in our work and the regulation of critical molecules involved in TLR signalling [32], which has not yet been evaluated in neonatal DCs, could account for the relative unresponsiveness of neonatal DCs to TLR stimulation by Gram-negative rods.

Although neonatal monocytes express similar mRNA levels of different TLRs compared with adult monocytes, these data do not exclude possible differences in the protein expression of these receptors $[32,40,41]$. In the present work, we observed similar expression of TLR-2 and TLR-4 in monocytes from all study groups, but the numbers of TLR $-2^{+}$and TLR $-4^{+}$monocytes were slightly higher in Groups 2 and 3. These observations agree with previous data that describe constitutive TLR-4 expression and cytokine secretion upon LPS stimulation that increases with gestational age [9].

Previous studies have shown that neonatal monocytes exhibit low baseline expression of the costimulatory molecules $\mathrm{CD} 40$ and CD86, potentially contributing to deficient APC activity, in contrast to our data [32]. We observed similar frequencies of monocytes expressing CD80 and CD86 across the groups, but the percentages of $\mathrm{CD} 0^{+}$monocytes were slightly lower in neonates than adults, although significantly different only for Group 2. We also observed reduced CD80 expression on mDCs and pDCs in neonates from Group 1 compared with Group 3 and adults, supporting the notion of deficient activity of APCs from very preterm newborns.

Upon contact with cognate MHC-peptide complexes on APCs, naive $\mathrm{T}$ cells become effector cells that are highly functional. These effector cells can differentiate into effector memory $\mathrm{T}$ cells and, later, into central memory $\mathrm{T}$ cells based on the expression of different cell surface molecules underlying homing markers, chemokines and cytokine receptors [42-47].

We observed higher frequencies of total lymphocytes in both groups of preterm neonates compared with full-term neonates and adults. However, the percentages of $\mathrm{T}$ helper cells were equivalent among all groups, with the exception of the comparison between full-term neonates and adults. These results have been shown by others $[6,15]$, and it has been discussed that this probably indicates that newborns with higher gestational age, which are ready to leave the protective environment of the uterus, need to mobilize a greater number of cells to the periphery to respond to 


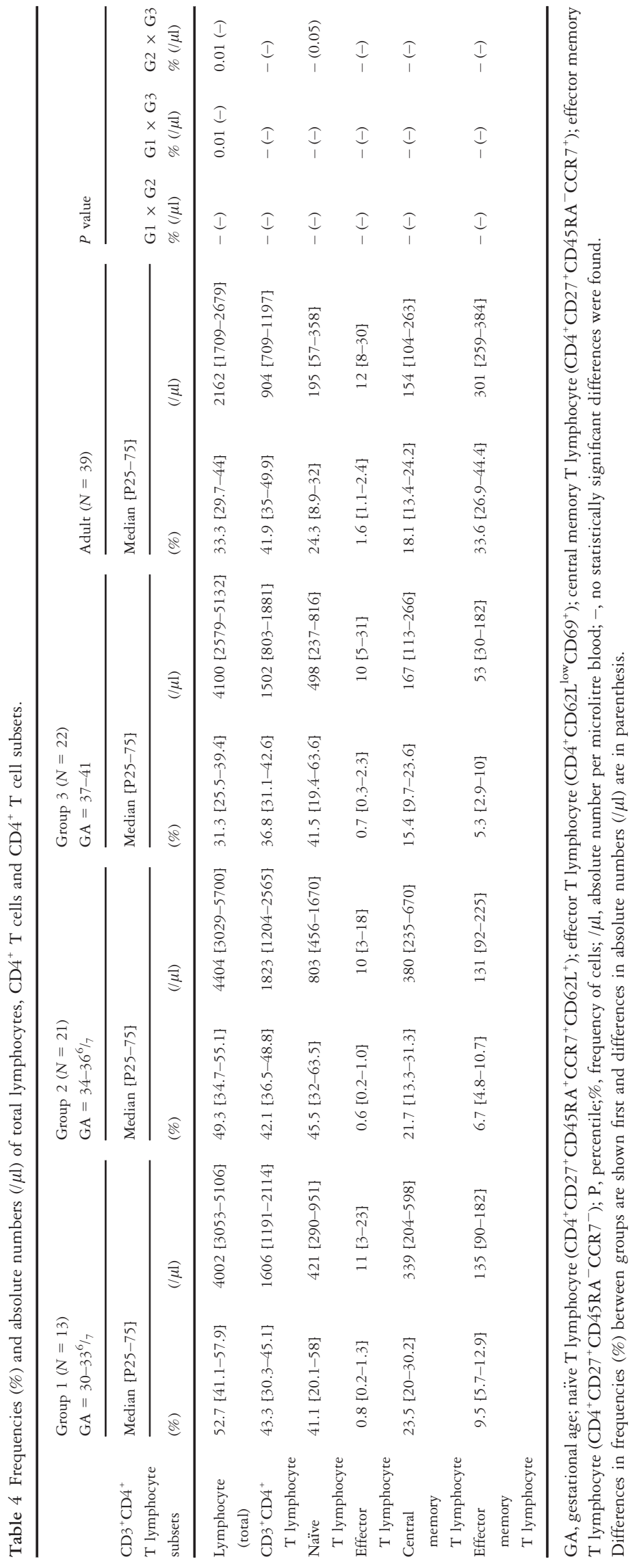


Total Lymphocytes
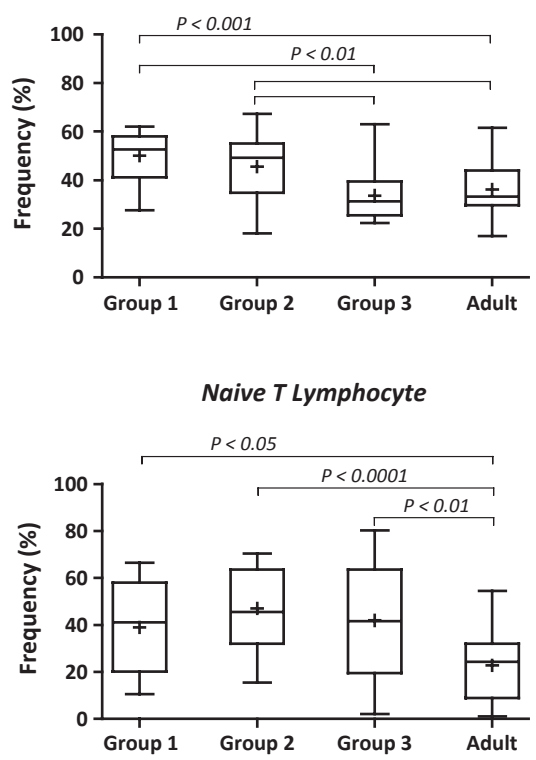

Central Memory T Lymphocyte

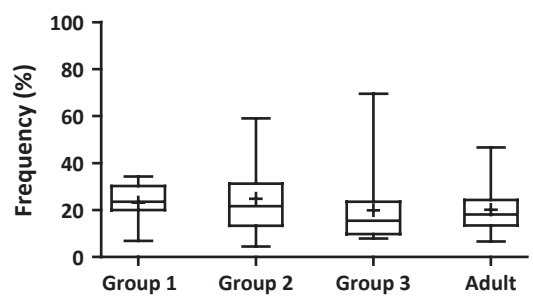

$\mathrm{CD}^{+} \mathrm{CD} 4^{+}$T Lymphocyte
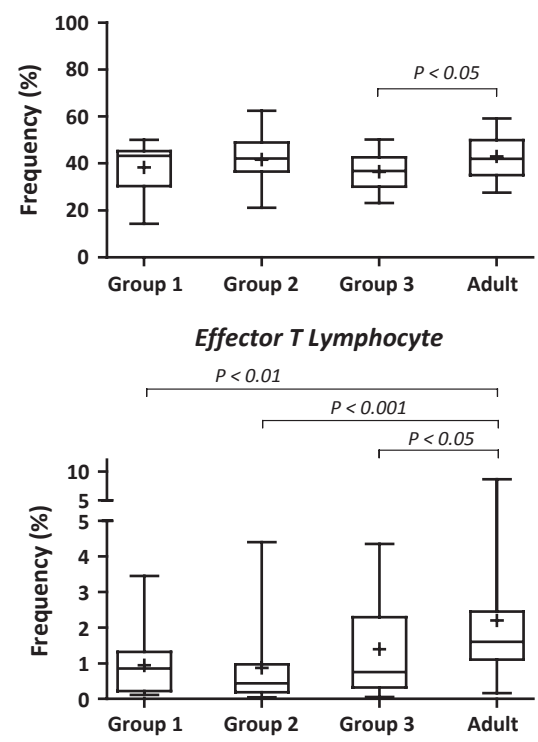

Effector Memory T Lymphocyte

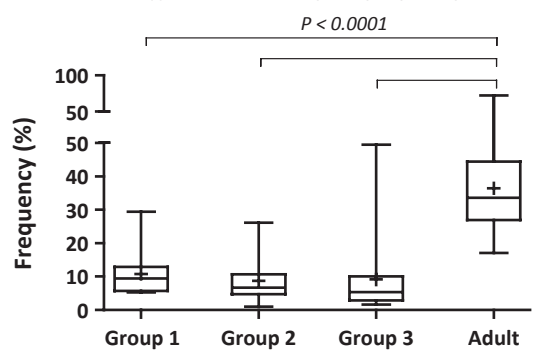

Figure 4 Frequencies of total lymphocytes, $\mathrm{TCD} 4^{+}$lymphocytes and their subsets in cord blood. Total lymphocytes; TCD $4^{+}$ lymphocytes and their subsets: naive, effector, central memory and effector memory $\mathrm{TCD}^{+}$lymphocytes in cord blood from preterm (Groups 1 and 2) and term (Group 3) newborns and in adult blood, as controls. Box plots: black crosses are the mean, black horizontal lines are medians, the solid lines of the box represent the 75 th and 25th percentiles, and the short lines outside the top and the base of the box represent the highest and the lowest values, respectively. possible infectious agents. This fact could also explain the lower frequencies of $\mathrm{mDCs}$ and $\mathrm{pDCs}$ in term neonates compared with preterm ones.

Naive $T$ cells are characterized by the expression of CD45RA and CCR7, the costimulatory receptors CD28 and $\mathrm{CD} 27$, and the lack of expression of cytolytic molecules. Long-lived central memory $\mathrm{T}$ cells home preferentially to lymph nodes because they express the lymph node-homing markers CD62L and CCR7 and share several phenotypic properties with naive $T$ cells but do not express CD45RA. Central memory T cells, as opposed to naive $\mathrm{T}$ cells, can rapidly differentiate into cells endowed with effector function upon exposure to antigen [43], can upregulate CD40L to a greater extent than naive cells and are characterized by their ability to proliferate and secrete high levels of IL-2.

In the present work, no significant differences in naive $T$ cells were observed among the newborns, although newborns from Group 1 showed a slightly lower relative number compared with the other neonates. An overall increase in naive $\mathrm{T}$ cells in neonates has been demonstrated previously, and it has also been shown that preterm neonates have reduced naive $T$ cell populations compared with full-term neonates $[6,8]$. It has been speculated that this difference is due to decreased thymic output or to decreased peripheral expansion of naive $\mathrm{T}$ cells because of more limited functional $\mathrm{T}$ cell capacities in extreme preterm infants [8]. The thymic output of naive $\mathrm{T}$ cells in term neonates has already been shown to be normal [48]. In disagreement with others [8, 49], the term group's naive T helper cells were significantly lower than those of late preterm newborns, and the number and frequency of $\mathrm{CD} 3{ }^{+} \mathrm{CD} 4^{+} \mathrm{T}$ lymphocytes were also somewhat reduced compared with the preterm groups. Pérez et al. [15] showed that the frequencies of neonatal $\mathrm{CD}^{+}$and $\mathrm{CD} 4^{+} \mathrm{T}$ cells followed a trend similar to ours, with the lowest values at 38 and 41 gestation weeks. These authors discuss that this fact might be due to the recruitment of the major number of cells at ganglia, the place where the mature cells wait until a stimulus causes them to leave to the periphery again, just at the 'normal' period of birth.

Surprisingly, central memory $\mathrm{T}$ cell frequencies were equivalent among preterm neonates and adults. These finding are in contrast to previous reports of a reduced frequency of memory $\mathrm{T}$ cells in neonates compared with adults. However, the effector memory and central memory $\mathrm{T}$ cell subsets were not distinguished in those reports [6]. Effector memory $\mathrm{T}$ cells preferentially migrate to peripheral tissues, do not express CD45RA or CCR 7 and may or 
may not express $\mathrm{CD} 27 / \mathrm{CD} 28$, depending on their state of differentiation [44]. Effector $\mathrm{T}$ cells are identified by the expression of various markers, including CD69 and CD25, and low levels of CD62L [47]. Because these cells have been already activated upon previous contact with antigen, the higher frequencies found in adults in this study would be expected.

Most B lymphocytes consist mainly of naive cells in full-term and preterm newborns, and our group and others have observed significantly reduced frequencies of memory $\mathrm{B}$ cells in neonates compared with adults $[8,48]$. More recently, it has been shown that memory B cells constitutively express TLR-2 to some degree [50]. In the present work, we observed extremely low frequencies of B lymphocytes expressing TLR-2 and TLR-4 in all groups, including adults (data not shown).

A premature birth is generally caused by negative perinatal factors such as maternal pre-eclampsia or intrauterine infection, and antenatal steroids are commonly used in preterm infants. These factors can influence lymphocyte subpopulations in neonatal cord blood [26, 28, 51, 52]. However, studies examining these factors reported relative values and not absolute values, which may lead to misinterpretation, as we and others have shown significantly increased numbers of leucocytes in preterm and term infants [26-29].

A growing body of evidence suggests that the incidence of medical problems, either short term or long term, is higher among late preterm infants than among term infants [53]. During the birth hospitalization, late preterm infants experience more difficulties with feeding ( $32 \%$ versus $7 \%$ ), hypoglycaemia ( $16 \%$ versus $5 \%$ ), jaundice ( $54 \%$ versus $38 \%$ ), temperature instability (10\% versus $0 \%)$, apnoea ( $6 \%$ versus $<0.1 \%)$ and respiratory distress (29\% versus $4 \%)$ compared with term infants. Late preterm infants also receive intravenous fluids ( $27 \%$ versus $5 \%$ ), evaluations for sepsis $(37 \%$ versus $13 \%)$ and mechanical ventilation $(3.4 \%$ versus $0.9 \%$ ) more often than their term counterparts [16]. In a large healthcare system, $88 \%$ of infants born at 34 weeks' gestation, $12 \%$ born at 37 weeks' gestation and $2.6 \%$ born at 38 40 weeks' gestation were admitted to an intensive care unit, showing that admission for intensive care is inversely proportional to gestational age [54]. Regarding infections, it was reported significantly more sepsis evaluations and culture-proven sepsis in the late preterm infants compared with term infants, with suspected or proven infections detected five times as frequently [55].

The heightened risk of bacterial infection in preterm infants has a number of determinants: first, extremely preterm infants require prolonged intensive care, including mechanical ventilation, parenteral feeding and intravenous access, which breach physical barriers against infection and facilitate invasion by nosocomial pathogens. Second, neonates are rapidly colonized by microbes in the intensive care environment. Third, many elements of the 


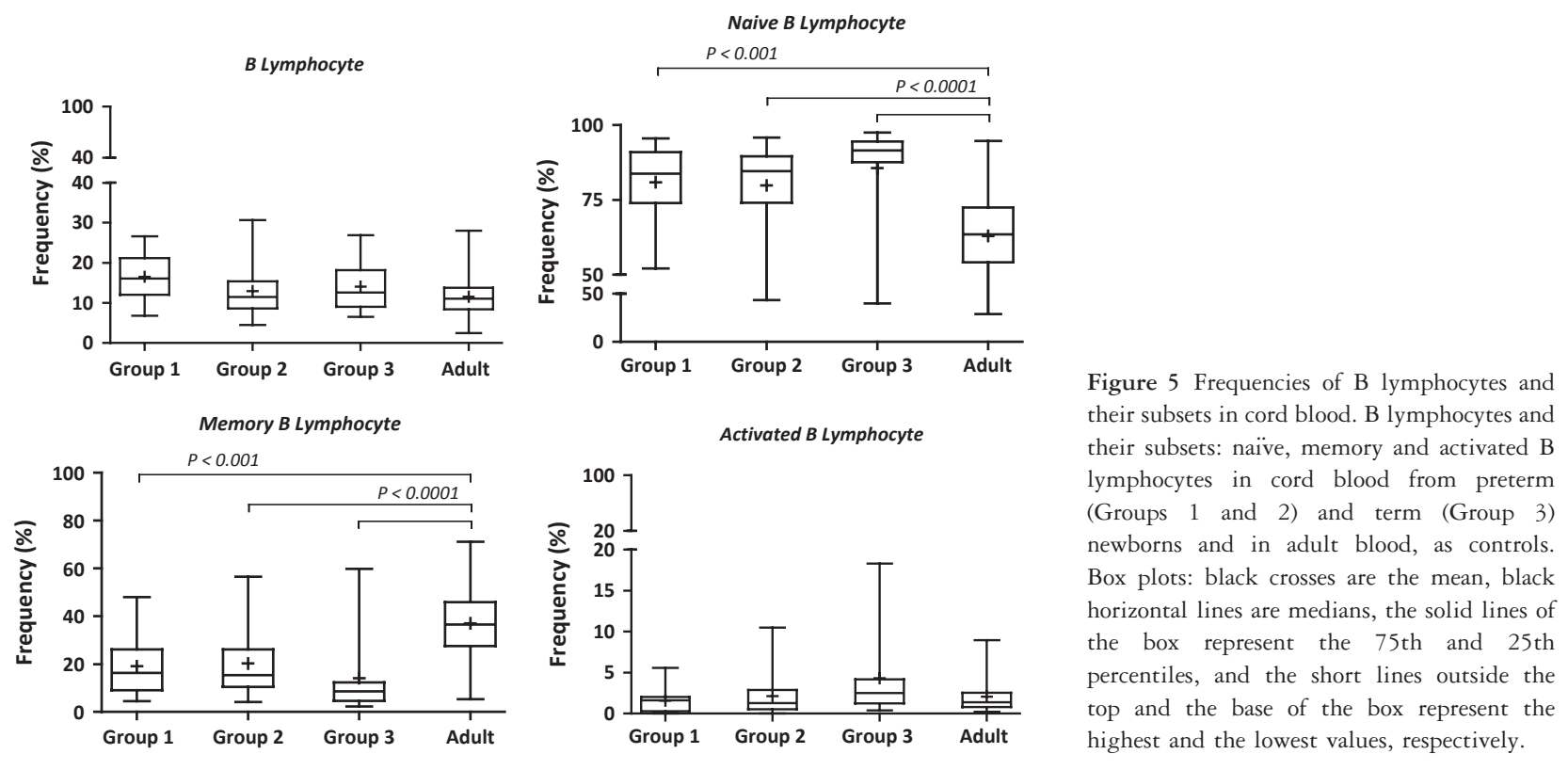

acquired immune system function less well in the neonate, with gestational and post-natal age among the most important determinants of immune function [56]. Here, in addition to the already well-described differences in $\mathrm{T}$ and B lymphocyte subpopulations compared with adults, we found lower numbers of monocytes and dendritic cells expressing the activation markers CD80 and CD86 and TLR-2 and TLR-4 in very preterm newborns from Group 1 compared with term newborns. Moreover, we showed lower numbers of $\mathrm{mDC} \mathrm{CD}^{+} 0^{+}, \mathrm{mDC} \mathrm{TLR}_{-} 2^{+}$and monocytes TLR $-4^{+}$in late preterm newborns compared with term ones.

Several studies have suggested that some innate immune mechanisms are impaired in neonates. However, it has been discussed that neonates are immunocompetent to mount mature innate as well as adult-level $\mathrm{T}$ cell responses [57]. In this work, we showed that neonates, particularly late preterm neonates, frequently have adequate tools to combat extracellular pathogens, as evidenced by the relative numbers of the majority of innate cells and the expression of pattern recognition and activation molecules. However, an appropriate number of cells do not indicate proper function; thus, it is imperative to clarify defective mechanisms that may underlie the immune responses in newborns and contribute to the overall risk of infection by common neonatal pathogens.

Our study provides a more thorough characterization of leucocyte subsets in cord blood from preterm and full-term newborns that may facilitate the identification of immunological deficiencies in the protection against extracellular pathogens. These data may also permit the development of clinical strategies to limit invasive medical interventions, particularly in the most vulnerable groups, such as extreme preterm newborns.

\section{Acknowledgment}

Financial support was provided by FAPESP (Fundação de Amparo à Pesquisa do Estado de São Paulo) Grants 2009/ 54246-5, 2009/52515-9, 2009/54400-4 and 2009/53864-7. The authors are grateful to the mothers who kindly agreed to participate in this study and Dr. Ulysses Doria Filho for statistical analysis.

\section{References}

1 Protonotariou E, Malamitsi-Puchner A, Rizos D et al. Age related differentiations of Th1/Th2 cytokines in newborn infants. Mediators Inflamm 2004;13:89-92.

2 Kotiranta-Ainamo A, Rautonen J, Rautonen N. Imbalanced cytokine secretion in newborns. Biol Neonate 2004;85:55-60.

3 Delespesse G, Yang LP, Ohshima Y et al. Maturation of human neonatal $\mathrm{CD}^{+}$and $\mathrm{CD}^{+} \mathrm{T}$ lymphocytes into Th1/Th2 effectors. Vaccine 1998;16:1415-19.

4 Malhotra I, Mungai P, Muchiri E et al. Distinct Th1- and Th2-Type prenatal cytokine responses to Plasmodium falciparum erythrocyte invasion ligands. Infect Immun 2005;73:3462-70.

5 Rabian-Herzog C, Lesage S, Gluckman E, Charron D. Characterization of lymphocyte subpopulations in cord blood. Bone Marrow Transplant 1992;9:64-7.

6 Peoples JD, Cheung S, Nesin M et al. Neonatal cord blood subsets and cytokine response to bacterial antigens. Am J Perinatol 2009;26:647-57.

7 Schelonka RL, Infante AJ. Neonatal immunology. Semin Perinatol 1998;22:2-14.

8 Walker JC, Smolders MA, Gemen EF, Antonius TA, Leuvenink J, de Vries E. Development of lymphocyte subpopulations in preterm infants. Scand J Immunol 2011;73:53-8.

9 Sadeghi K, Berger A, Langgartner $\mathrm{M}$ et al. Immaturity of infection control in preterm and term newborns is associated with impaired toll-like receptor signaling. J Infect Dis 2007;195:296-302.

10 Stoll BJ, Hansen NI, Higgins RD et al. Very low birth weight preterm infants with early onset neonatal sepsis: the predominance of 
gram-negative infections continues in the National Institute of Child Health and Human Development Neonatal Research Network, 20022003. Pediatr Infect Dis J 2005;24:635-9.

11 de Vries E, de Groot R, de Bruin-Versteeg S, Comans-Bitter WM, van Dongen JJ. Analysing the developing lymphocyte system of neonates and infants. Eur J Pediatr 1999;158:611-17.

12 Clapp DW, Kliegman RM, Baley JE et al. Use of intravenously administered immune globulin to prevent nosocomial sepsis in low birth weight infants: report of a pilot study. J Pediatr 1989;115:973-8.

13 Wang ML, Dorer DJ, Fleming MP, Catlin EA. Clinical outcomes of near-term infants. Pediatrics 2004;114:372-6.

14 Clapp DW. Developmental regulation of the immune system. Semin Perinatol 2006;30:69-72.

15 Pérez A, Gurbindo MD, Resino S, Aguarón A, Muñoz-Fernández MA. NK cell increase in neonates from the preterm to the full-term period of gestation. Neonatology 2007;92:158-63.

16 Engle WA, Kominiarek MA. Late preterm infants, early term infants, and timing of elective deliveries. Clin Perinatol 2008;35:325-41.

17 Koumbi LJ, Papadopoulos NG, Anastassiadou V, Machaira M, Kafetzis DA, Papaevangelou V. Dendritic cells in uninfected infants born to hepatitis B virus-positive mothers. Clin Vaccine Immunol 2010;17:1079-85.

18 Shin S, Jang JY, Roh EY et al. Differences in circulating dendritic cell subtypes in pregnant women, cord blood and healthy adult women. $J$ Korean Med Sci 2009;24:853-9.

19 Sorg RV, Kögler G, Wernet P. Identification of cord blood dendritic cells as an immature CD11c- population. Blood 1999;93:2302-7.

20 Schreibelt G, Tel J, Sliepen KH et al. Toll-like receptor expression and function in human dendritic cell subsets: implications for dendritic cell-based anti-cancer immunotherapy. Cancer Immunol Immunother 2010;59:1573-82.

21 Engle WA. A recommendation for the definition of "Late Preterm" (Near-Term) and the birth weight-gestational age classification system. Semin Perinatol 2006;30:2-7.

22 Milcic TL. The complete blood count. Neonatal Netw 2010;29:10915.

23 Christensen RD, Henry E, Jopling J, Wiedmeier SE, . The CBC: reference ranges for neonates. Semin Perinatol 2009;33:3-11.

24 Berrington JE, Barge D, Fenton AC, Cant AJ, Spickett GP. Lymphocyte subsets in term and significantly preterm UK infants in the first year of life analyzed by single platform flow cytometry. Clin Exp Immunol 2005;140:289-92.

25 Sharma AA, Jen R, Butler A, Lavoie PM. The developing human preterm neonatal immune system: a case for more research in this area. Clin Immunol 2012;145:61-8.

26 Juretić E, Uzarević B, Petrovecki M, Juretić A. Two color flow cytometric analysis of preterm and term newborn lymphocytes. Immunobiology 2000;202:421-8.

27 Juretić E, Juretić A, Uzarević B, Petrovecki M. Alterations in lymphocyte phenotype of infected preterm newborns. Biol Neonate 2001;80:223-7.

28 Kotiranta-Ainamo A, Apajasalo M, Pohjavuori M, Rautonen N, Rautonen J. Mononuclear cell subpopulations in preterm and full term neonates: independent effect of gestational age, neonatal infection, maternal pre-eclampsia, maternal betamethasone therapy, and mode of delivery. Clin Exp Immunol 1999;115:309-14.

29 Comans-Bitter WM, de Groot R, van den Beemd R et al. Immunophenotyping of blood lymphocytes in childhood. Reference values for lymphocyte subpopulations. J Pediatr 1997;130:388-93.

30 Ito T, Liu YJ, Kadowaki N. Functional diversity and plasticity of human dendritic cell subsets. Int J Hematol 2005;81:188-96.

31 Kadowaki N. The divergence and interplay between $\mathrm{pDC}$ and $\mathrm{mDC}$ in humans. Front Biosci (Landmark Ed) 2009;14:808-17.

32 Velilla PA, Rugeles MT, Chougnet CA. Defective antigen-presenting cell function in human neonates. Clin Immunol 2006;121:251-9.
33 Adams S, O'Neill DW, Bhardwaj N. Recent advances in dendritic cell biology. J Clin Immunol 2005;25:177-88.

34 Collin M, McGovern N, Haniffa M. Human dendritic cell subsets. Immunology 2013;140:22-30.

35 Akira S, Takeda K, Kaisho T. Toll-like receptors: critical proteins linking innate and acquired immunity. Nat Immunol 2001;2:67580.

36 Aderem A, Ulevitch RJ. Toll-like receptors in the induction of the innate immune response. Nature 2000;406:782-7.

37 Janeway CA Jr, Medzhitov R. Innate immune recognition. Annu Rev Immunol 2002;20:197-216.

38 Gulubova MV, Ananiev JR, Vlaykova TI, Yovchev Y, Tsoneva V, Manolova IM. Role of dendritic cells in progression and clinical outcome of colon cancer. Int J Colorectal Dis 2012;27:159-69.

39 Drohan L, Harding JJ, Holm B et al. Selective developmental defects of cord blood antigen-presenting cell subsets. Hum Immunol 2004;65:1356-69.

40 Förster-Waldl E, Sadeghi K, Tamandl D et al. Monocyte toll-like receptor 4 expression and LPS-induced cytokine production increase during gestational aging. Pediatr Res 2005;58:121-4.

41 Levy O, Zarember KA, Roy RM, Cywes C, Godowski PJ, Wessels MR. Selective impairment of TLR-mediated innate immunity in human newborns: neonatal blood plasma reduces monocyte TNF alpha induction by bacterial lipopeptides, lipopolysaccharide, and imiquimod, but preserves the response to R-848. J Immunol 2004:173:4627-34.

42 Sallusto F, Geginat J, Lanzavecchia A. Central memory and effector memory T cell subsets: function, generation, and maintenance. Annu Rev Immunol 2004;22:745-63.

43 Sallusto F, Lenig D, Förster R, Lipp M, Lanzavecchia A. Two subsets of memory $\mathrm{T}$ lymphocytes with distinct homing potentials and effector functions. Nature 1999;401:708-12.

44 Hazenberg MD, Otto SA, Hamann D et al. Depletion of naive CD4 T cells by CXCR4-using HIV-1 variants occurs mainly through increased T-cell death and activation. AIDS 2003;17:1419-24.

45 Masopust D, Vezys V, Marzo AL, Lefrançois L. Preferential localization of effector memory cells in nonlymphoid tissue. Science 2001;291:2413-17.

46 Willinger T, Freeman T, Hasegawa H, McMichael AJ, Callan MF. Molecular signatures distinguish human central memory from effector memory CD8 T cell subsets. J Immunol 2005;175:5895903.

47 Tanel A, Fonseca SG, Yassine-Diab B et al. Cellular and molecular mechanisms of memory T-cell survival. Expert Rev Vaccines 2009;8:299-312.

48 van Gent R, van Tilburg CM, Nibbelke EE et al. Refined characterization and reference values of the pediatric T- and B-cell compartments. Clin Immunol 2009;133:95-107.

49 Schatorjé EJ, Gemen EF, Driessen GJ, Leuvenink J, van Hout RW, de Vries E. Paediatric reference values for the peripheral $\mathrm{T}$ cell compartment. Scand J Immunol 2012;75:436-44.

50 Lanzavecchia A, Bernasconi N, Traggiai E, Ruprecht CR, Corti D, Sallusto F. Understanding and making use of human memory B cells. Immunol Rev 2006;211:303-9.

51 Kavelaars A, van der Pompe G, Bakker JM et al. Altered immune function in human newborns after prenatal administration of bethamethasone: enhanced natural killer cell activity and decreased $\mathrm{T}$ cell proliferation in cord blood. Pediatr Res 1999;45:306-12.

52 Chabra S, Cottrill C, Rayens MK, Cross R, Lipke D, Bruce M. Lymphocyte subsets in cord blood of preterm infants: effect of antenatal steroids. Biol Neonate 1998;74:200-7.

53 Dong Y, Yu JL. An overview of morbidity, mortality and longterm outcome of late preterm birth. World J Pediatr 2011;7:199204 . 
54 Escobar GJ, Greene JD, Hulac P et al. Rehospitalization after birth hospitalization: patterns among infants of all gestations. Arch Dis Child 2005;90:125-31.

55 Boyle JD, Boyle EM. Born just a few weeks early: does it matter? Arch Dis Child Fetal Neonatal Ed 2013;98:F85-8.
56 Strunk T, Currie A, Richmond P, Simmer K, Burgner D. Innate immunity in human newborn infants: prematurity means more than immaturity. J Matern Fetal Neonatal Med 2011;24:25-31.

57 Maródi L. Neonatal innate immunity to infectious agents. Infect Immun 2006;74:1999-2006. 
APÊNDICE D - TLR-2 and TLR-4 expression in monocytes of newborns with late-onset sepsis 


\title{
Jornal de

\section{TLR-2 and TLR-4 expression in monocytes of newborns

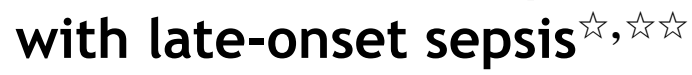

\section{Ana C.C. Redondo ${ }^{a}$, Maria E.J.R. Ceccon ${ }^{a, *}$, Ana L. Silveira-Lessa ${ }^{b}$, Camila Quinello ${ }^{c}$, Patrícia Palmeira $^{c}$, Werther B. Carvalho ${ }^{d}$, Magda Carneiro-Sampaio ${ }^{\mathrm{e}}$}

\author{
a Neonatal Intensive Care Unit, Instituto da Criança, Hospital das Clínicas, Faculdade de Medicina, Universidade de São Paulo \\ (USP), São Paulo, SP, Brazil \\ b Department of Parasitology, Instituto de Ciências Biomédicas, Universidade de São Paulo (USP), São Paulo, SP, Brazil \\ c Laboratory of Medical Investigation (LIM-36), Instituto da Criança, Hospital das Clínicas, Faculdade de Medicina, Universidade \\ de São Paulo (USP), São Paulo, SP, Brazil \\ ' Department of Neonatology, Faculdade de Medicina, Universidade de São Paulo (USP), São Paulo, SP, Brazil \\ e Department of Pediatrics, Faculdade de Medicina, Universidade de São Paulo (USP), São Paulo, SP, Brazil
}

Received 1 October 2013; accepted 26 December 2013

Available online 27 May 2014

\section{KEYWORDS}

Sepsis/immunology; Innate immunity; Toll-like receptor 2; Toll-like receptor 4; Newborn; Monocytes

\begin{abstract}
Objective: To analyze toll-like receptor (TLR)-2 and TLR-4 expression in monocytes of newborns with late-onset sepsis.

Methods: This prospective study included 27 full-term newborns aged 8 to 29 days, with clinical and laboratory diagnosis of late-onset sepsis. Ten newborns (37\%) had positive cultures. Cytokines were measured by cytometric bead array in peripheral blood, while TLR-2, TLR-4 expression, and median fluorescence intensity (MFI) were determined by immunophenotyping peripheral whole blood monocytes, and were analyzed with a BD FACSDiva flow cytometer (Becton, Dickinson and Company, USA). A comparison was performed with healthy adults.

Results: Microorganisms were identified in $37 \%$ of these septic newborns, and all of them had high levels of pro-inflammatory cytokines (IL-8, IL-6, IL-1 $\beta$ ) and anti-inflammatory cytokine (IL-10) corroborating the inflammatory/septic process. In monocytes, the frequency of TLR-4 expression was higher in infected newborns $(p=0.01)$.

Conclusion: This study investigated the innate immune response in septic newborns. Septic newborns that relied almost exclusively on the innate immune system showed little in vivo response at monocyte activation, suggesting impaired immune response and increased susceptibility to infection.
\end{abstract}

(c) 2014 Sociedade Brasileira de Pediatria. Published by Elsevier Editora Ltda. All rights reserved.

\footnotetext{
Please cite this article as: Redondo AC, Ceccon ME, Silveira-Lessa AL, Quinello C, Palmeira P, Carvalho WB, et al. TLR-2 and TLR-4 expression in monocytes of newborns with late-onset sepsis. J Pediatr (Rio J). 2014;90:472-8.

站访 Study conducted at Instituto da Criança, Hospital das Clínicas, Faculdade de Medicina, Universidade de São Paulo, São Paulo, Brazil.

* Corresponding author.

E-mail: maria.esther@hc.fm.usp.br (M.E.J.R. Ceccon).
} 


\section{PALAVRAS-CHAVE}

Sepse/imunologia; Imunidade inata; Receptor 2 toll-like; Receptor 4 toll-like; Recém-nascidos; Monócitos

\section{Introduction}

Sepsis represents a major cause of morbidity and mortality in the newborn, ${ }^{1,2}$ whose severity is proportional to the interaction between the host and the causative agent, triggering a cascade of events responsible for the immune response expression.

Late-onset sepsis occurs after 72 hours of life, with clinical signs and symptoms that may be subtle and nonspecific early in the infection, which are often misinterpreted or mistaken for other non-infectious clinical conditions. Nevertheless, its evolution can be fulminant, leading to septic shock, disseminated intravascular coagulation, and death within hours. ${ }^{3-5}$

Differently from the adult, several degrees of deficiency have been described in the newborn regarding the innate and adaptive immune responses. ${ }^{6}$ At birth, the adaptive immune response is impaired, both by the minimal in utero antigen exposure and by $B$ and $T$ effector cell dysfunction. ${ }^{1}$ Because of that, the newborn relies on the effectiveness of the innate immune response and the passive protection of maternal antibodies acquired transplacentally. ${ }^{7}$

A primordial part of the innate immune response trigger corresponds to the activation of the toll-like receptors (TLRs), expressed on the surface of monocytes, macrophages, dendritic cells, lymphocytes, epithelial cells, or in the cytoplasm of different tissue cells. Of the ten types of receptors described in humans, TLR-2 and TLR- 4 mainly recognize components of Gram-positive and Gram-negative bacteria, respectively.

The signal transduction activation recruits several intracellular proteins (MyD88, IRAK, and TRAF-6), which trigger the activation of JNK (Jun amino-terminal kinases) and
ERK (extracellular signal-regulated kinases) pathways in the cascade of mitogen-activated protein kinases (MAPKs). This induces the activation of transcription factors activator protein 1 (AP-1) and nuclear factor kappa B (NF-kB) that express several genes directly involved in the production of inflammatory cytokines in response to infection, playing a key role in the amplification of cell immune response. ${ }^{8-11}$

Monocytes are antigen-presenting cells that act on the inflammatory process and as a source of macrophages and dendritic cells. After activation through TLRs, there is an increase in the expression of costimulatory molecules (CD80 and CD86), which are important in the early adaptive immune response and cytokine production. ${ }^{12}$

The regulation of the immune system at birth results in a biased TLR neonatal response by stimulating a lower production of pro-inflammatory cytokines and demonstrating lower multi-functionality. ${ }^{13,14}$ Only in the course of life do cytokine levels become equivalent to those of the adult individual. ${ }^{15}$ However, in the neonatal period, quantitative and qualitative changes in TLRs and cells participating in the innate immune response have been described when compared to the adult individual, which are proportional to gestational age at birth. ${ }^{16}$ These differences could elucidate the increased susceptibility to infection observed in the neonatal age group. ${ }^{1,17}$

Therefore, despite the growing awareness of the importance of the TLR system in protecting newborns against infections, ${ }^{18}$ much still needs to be clarified about the mechanisms of regulation of TLR responses in the neonatal period. Thus, this study aimed to characterize the expression of TLR-2 and TLR-4 in monocytes of full-term newborns with late-onset sepsis. 


\section{Methods}

This was a prospective study, whose convenience sample included 27 full-term newborns transferred to the neonatal intensive care unit (NICU) of the Instituto da Criança- Hospital das Clínicas da Faculdade de Medicina da Universidade de São Paulo (HCFMUSP), from February of 2011 to January of 2013. Patients whose gestational age ranged from 37 to 42 weeks and showed clinical and/or laboratory symptoms (complete blood count and C-reactive protein) of neonatal sepsis from 72 hours up to 30 days of life at the time of admission or during hospitalization, which led to the start of antibiotic therapy, were included in the study.

Exclusion criteria were factors that alone would alter the immune response, such as: diagnosis of congenital infections, inborn errors of metabolism, use of anti-inflammatory drugs (indomethacin, ibuprofen, and steroids), diagnosis of intracranial hemorrhage confirmed by skull ultrasound or computed tomography and surgery in the week before, in addition to those in which the date of sample collection did not permit analysis.

The criteria used to define and classify the diagnosis regarding clinical severity (sepsis, severe sepsis, and septic shock) were those mentioned in the Surviving Sepsis Campaign (2012), adjusted for age range based on the criteria of Goldstein (2005) as determined by the consensus. ${ }^{19,20}$ The complete blood counts (CBC) analysis was based on the Hematologic Scoring System (HSS) of Rodwell, whereas CRP (C-reactive protein) level $>10 \mathrm{mg} / \mathrm{L}$ was considered suggestive of infection. The study was approved by the Ethics Committee for Analysis of Research Projects of the HCFMUSP (CAPPesq).

\section{Sampling}

After an informed consent was obtained from the legal guardians of the newborn, blood samples were collected by venipuncture from a peripheral vein for assessment of infectious picture (CBC, CRP, and blood culture) and analysis of cytokines and monocytes. The time of collection was standardized to occur within the first 24 hours from the suspected diagnosis of infection and the start of antibiotic therapy. An aliquot of $0.5 \mathrm{~mL}$ of blood was distributed in a separator tube with gel for cytokine measurement, and $1.5 \mathrm{~mL}$ was placed in a tube with EDTA (Ethylenediamine tetraacetic acid) for immunophenotyping, which were both performed at the Laboratory of Medical Investigation 36 (LIM 36) of Instituto da Criança of HCFMUSP.

\section{Cytokine analysis}

Cytokines TNF- $\alpha, \mathrm{IL}-1 \beta$, IL-2, IL-4, IL-6, IL-8, and IL-10 were measured in serum samples using a human cytometric bead array (CBA) set (Cytometric bead array BD OptEIA ${ }^{\mathrm{TM}}$ Set Human, Becton, Dickinson and Company, USA) according to the manufacturer's instructions.

\section{Analysis of TLRs}

Immunophenotyping was performed with the sample red blood cells, which were collected in tubes containing EDTA after being prepared for addition of pre-established antibodies (Table 1) and processed until they were transferred to be read in the flow cytometer FACS II LRS Fortessa (Becton, Dickinson and Company, USA). The monocyte population was defined by gating of CD14+HLA-DR+ cells using the size (forward scatter - FSC) and cell granularity as parameters (side scatter - SSC) as described in the literature. ${ }^{20}$

The analysis was performed in FlowJo software (Tree Star - Ashland, OR, United States), where each cell population was analyzed separately by gating using cell size and granularity as parameters. The same software provided data representing the median fluorescence intensity (MFI) of the respective markers.

The absolute numbers of populations were calculated by multiplying the percentage indicated for each population in flow cytometry and the absolute number of leukocytes determined by automatic cell counter.

\section{Blood control samples from healthy adults}

Peripheral blood samples were obtained from 27 healthy adults and used for test standardization and control. The selection criteria were: healthy adult volunteers; aged 1835 years; of both genders; with negative serological tests for human immunodeficiency virus (HIV), HTLV I/II (Human T lymphotropic virus type I/II), hepatitis B and C, syphilis, and Chagas disease; and no symptoms of infection during the collection period.

Table 1 Monocyte cell surface markers.

\begin{tabular}{llll}
\hline Monoclonal antibody & \multicolumn{1}{c}{ Clone } & Fluorochrome & Manufacturer \\
\hline HLA-DR & L243 & APC Cy7 & BD Biosciences \\
CD14 & M5E2 & Pacific blue & BD Biosciences \\
CD80 & BB1 & FITC & BD Biosciences \\
CD86 & $2331($ FUN-1) & PE Cy5 & BD Biosciences \\
TLR-2 (CD282) & 11G7 & Alexa 647 & BD Biosciences \\
TLR-4 (CD284) & HTA 125 & PE & BioLegend \\
\hline
\end{tabular}

HLA-DR, human leukocyte antigen class II-DR locus; CD, cluster of differentiation; TLR, toll-like receptor; APC Cy7, allophycocyanin combined with cyanine dye; Pacific blue, 6,8-difluoro-7-hydroxycoumarin fluorophore; FITC, fluorescein isothiocyanate; PE Cy5, conjugate of phycoerythrin and cyanine dye; Alexa 647, fluorochrome for reading between 594 and $633 \mathrm{~nm}$; PE, R-phycoerythrin. Clone, refers to the specified markers of monoclonal antibodies.

a BioLegend Inc. (San Diego, CA, United States) 
Table 2 Distribution of 27 newborns according to the clinical and laboratory data.

\begin{tabular}{|c|c|c|c|}
\hline \multicolumn{4}{|c|}{ CLINICAL DATA (Median $\left[25^{\text {th }}-75^{\text {th }}\right.$ percentile]) } \\
\hline Age at admission (days) & & \multicolumn{2}{|c|}{$11(2-22)$} \\
\hline Age at symptom onset (days) & & \multicolumn{2}{|c|}{$20(8-29)$} \\
\hline Age at collection (days) & & \multicolumn{2}{|c|}{$21(12-30)$} \\
\hline Weight (g) & & \multicolumn{2}{|c|}{$3,130(2,823-3,511)$} \\
\hline Gender (M:F) & & \multicolumn{2}{|c|}{ 1.07: 1} \\
\hline \multicolumn{4}{|c|}{ LABORATORY ASSESSMENT (Median $\left[25^{\text {th }}-75^{\text {th }}\right.$ percentile]) } \\
\hline - HSS & & \multicolumn{2}{|c|}{$1(0-3)$} \\
\hline - CRP (mg/L) & & \multicolumn{2}{|c|}{$35.2(9-83.1)$} \\
\hline \multicolumn{4}{|l|}{ Cultures (N [\%]) } \\
\hline - Positive cultures & & \multicolumn{2}{|c|}{$10(37 \%)$} \\
\hline Gram-positive bacteria & & \multicolumn{2}{|c|}{$4(40 \%)$} \\
\hline Staphylococcus epidermidis & & \multicolumn{2}{|c|}{3} \\
\hline Staphylococcus aureus & & \multicolumn{2}{|l|}{1} \\
\hline Gram-negative bacteria & & \multicolumn{2}{|c|}{$6(60 \%)$} \\
\hline Enterobacter cloacae & & \multicolumn{2}{|l|}{1} \\
\hline Salmonella sp. & & \multicolumn{2}{|l|}{1} \\
\hline Escherichia coli & & \multicolumn{2}{|l|}{$2^{a}$} \\
\hline Klebsiella pneumoniae & & \multicolumn{2}{|l|}{1} \\
\hline Bordetella pertussis & & \multicolumn{2}{|l|}{1} \\
\hline - Negative cultures & & \multicolumn{2}{|c|}{17 (63\%) } \\
\hline $\begin{array}{l}\text { CYTOKINES pg/mL } \\
\left.\text { [Median }\left(25^{\text {th }}-75^{\text {th }} \text { percentile }\right)\right]\end{array}$ & Positive culture & Negative culture & $\mathrm{p}$ \\
\hline- IL-6 & $147.7(72.2-385.1)$ & $132.3(6.3-332)$ & 0.6066 \\
\hline- IL-8 & $137.9(61.1-411.8)$ & $58.1(16.3-55.4)$ & 0.5414 \\
\hline$-I L-1 \beta$ & $3.0(1.07-15.8)$ & $2.55(1.15-5.62)$ & 0.5349 \\
\hline$-I L-10$ & $8.05(4.12-19.9)$ & $3.5(1.8-76.15)$ & 0.4516 \\
\hline- TNF- $\alpha$ & $1.2(0.45-1.7)$ & $1.75(1.0-2.47)$ & 0.1188 \\
\hline- IL-2 & $1.7(1.4-1.9)$ & $2.4(1.6-4.55)$ & 0.1014 \\
\hline$-I L-4$ & $2.2(0.85-2.8)$ & $0.4(0.3-1.1)$ & 0.0714 \\
\hline
\end{tabular}

HSS, hematologic scoring system of Rodwell; CRP, C-reactive protein; IL, interleukin; TNF- $\alpha$, tumor necrosis factor alpha.

a One patient with positive urine culture for Escherichia coli.

\section{Statistical analysis}

The newborn data were recorded on the collection forms and stored in spreadsheets from the statistical package GraphPad Prism ${ }^{\circledR}$, release 6.0c for Mac OSX (GraphPad Software, La Jolla California, United States). For qualitative variables, absolute and relative frequencies (percentage and number of cases) were calculated, whereas for quantitative variables, the median, the minimum and maximum values, and interquartile range (P25-P75) were calculated for each of the receptors evaluated in each analysis. The Mann-Whitney test was used to compare the median of markers between the groups, while the comparative analysis of the medians of more than two groups used the Kruskal-Wallis test with Dunn's post-test. The tests were performed with $95 \%$ confidence intervals and a $\mathrm{p}$-value $<0.05$ was considered significant.

\section{Results}

Clinical and laboratory characteristics of the 27 infants included in the study are shown in Table 2. It can be observed that most patients $(62.9 \%)$ had symptoms compatible with severe sepsis (44.4\%) and septic shock (18.5\%), which occurred at a median age of 20 days of life; death was observed in only two patients (7.4\%). Among the 17 patients who had negative cultures, all showed clear clinical signs and symptoms of infection and compatible laboratory alterations in the CBC and CRP levels at diagnosis and subsequent clinical analysis, and thus were considered patients with clinical sepsis.

Of these patients with clinical sepsis, eight $(47 \%)$ had a clinical picture compatible with sepsis, five (29.5\%) with severe sepsis, and four (23.5\%) with septic shock. Moreover, the measurement of pro-inflammatory cytokines was similar in infected patients regardless of positive cultures, as shown in Table 2. Culture positivity in material collected from sterile fluids (blood, urine, and CSF) occurred in ten patients $(37 \%)$, with distribution according to the isolated agent as shown in the same table.

Regarding monocytes, it can be observed that despite the fact that their total absolute number was higher in newborns when compared to adults ( $p<0.0001)$, there was a similar frequency of monocytes between groups (Fig. 1).

MFI for activation molecules CD80, CD86; and frequency and MFI for TLR-2 and TLR-4 are shown in Fig. 1. In addition to a lower MFI for CD86 in newborns with infection, these 

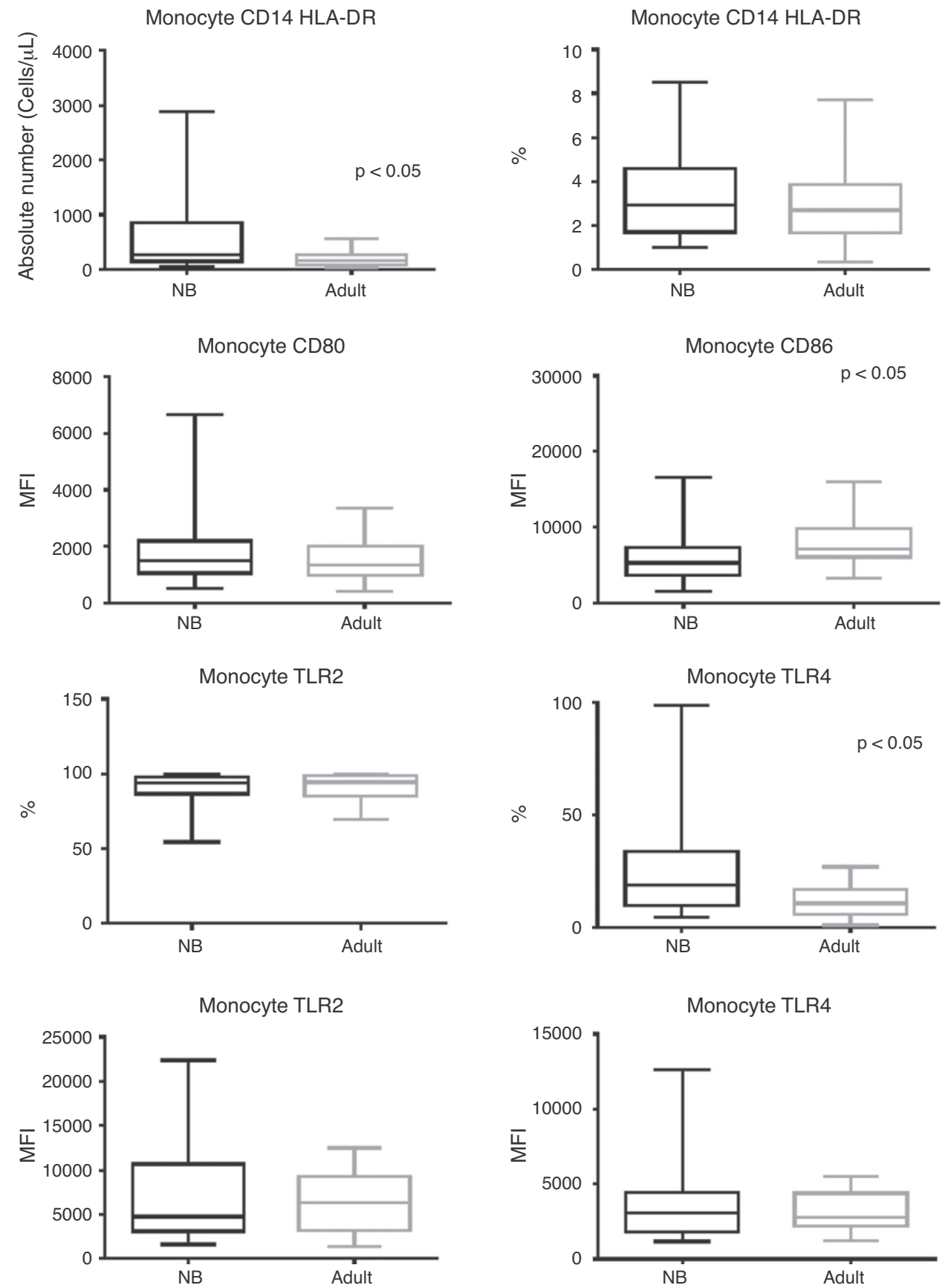

Figure 1 Box plot of absolute numbers (cells/ $\mu \mathrm{L}$ ), frequency (\%), and median fluorescence intensity (MFI) of CD80, CD86, TLR-2, and TLR-4 activation molecules. Values expressed as median \pm interquartile range (P25-P75); $p$ refers to statistical significance. Sample number of the "newborn" and "adult" groups $=27$.

NB, newborn; HLA-DR, human leukocyte antigen class II-DR locus; CD, cluster of differentiation; TLR, toll-like receptor.

patients showed maintenance of CD80 and TLR-2 expression $(p=0.822$ and $p=0.825$, respectively), while there was a higher frequency for TLR-4 in septic newborns when compared to adults ( $p=0.0043$ ).

Culture positivity was associated to a higher frequency of TLR- 4 when compared to adults and patients with negative cultures (Table 3), while there was a similar frequency between groups in the evaluation of TLR-2.

Despite the identification of some bacteria, the analysis between culture positivity according to the type of bacteria identified and the types of TLR was not performed due to the sample number.

\section{Discussion}

This study described the in vivo response of neonatal peripheral blood monocytes in the presence of an infectious picture, which showed similar or lower expression of activation molecules, in addition to increased expression of TLR-4 
Table 3 Median frequency (\%) and MFI of toll-like receptors 2 and 4 in peripheral blood monocytes of infected newborns (positive or negative culture), and adult peripheral blood.

\begin{tabular}{|c|c|c|c|c|}
\hline Monocytes & Adult & $\begin{array}{l}\text { Negative Culture } \\
\text { [N] Median (2) }\end{array}$ & $\begin{array}{l}\text { Positive Culture } \\
\text { entile) }\end{array}$ & $p$ \\
\hline \multicolumn{5}{|l|}{$\%$} \\
\hline TLR-2 & $\begin{array}{l}{[27] 93.5} \\
(82-98.5)\end{array}$ & $\begin{array}{l}{[17] 96.5} \\
(82.2-97.6)\end{array}$ & $\begin{array}{l}{[10] 87.1} \\
(59-92.2)\end{array}$ & 0.475 \\
\hline TLR-4 & $\begin{array}{l}{[27] 10.6} \\
(5.7-17.9)\end{array}$ & $\begin{array}{l}{[17] 11.8} \\
(6.7-24.9)\end{array}$ & $\begin{array}{l}{[10] 30.5} \\
(18.5-72.1)\end{array}$ & 0.0011 \\
\hline \multicolumn{5}{|l|}{ MFI } \\
\hline TLR-2 & $\begin{array}{l}{[27] 3,134} \\
(1,336-6,386)\end{array}$ & $\begin{array}{l}{[17] 8,631} \\
(2,972-15,300)\end{array}$ & $\begin{array}{l}{[10] 5,504} \\
(3,921-42,850)\end{array}$ & 0.516 \\
\hline TLR-4 & $\begin{array}{l}{[27] 2,768} \\
(2,159-4,377)\end{array}$ & $\begin{array}{l}{[17] 4,276} \\
(1,594-5,088)\end{array}$ & $\begin{array}{l}{[10] 3,204} \\
(2,017-3,831)\end{array}$ & 0.867 \\
\hline
\end{tabular}

$\mathrm{p}$ refers to statistical significance using the Kruskal-Wallis test.

MFI, median fluorescence intensity; TLR, toll-like receptor.

in newborns with infection caused by Gram-positive and Gram-negative bacteria, and increased expression of TLR-2 in patients with clinical sepsis.

Monocytes are phagocytic cells, and play an important role in innate and acquired immunity through their effects on the inflammatory process or as a source of macrophages and dendritic cells. The behavior of TLRs in the newborn, either in healthy or infected infants, is controversial. According to Levy et al., although the basal expression of TLRs in monocytes of full-term newborns is similar to that of adult individuals, the functional consequences of activation are quite different, as a lower production of cytokines and lower expression of co-stimulatory molecules are observed in newborns. ${ }^{18}$

It was observed that in the presence of an infectious stimulus, the population of assessed newborns showed a lower number of activated cells (lower MFI for CD86 than in the adult individual and MFI for CD80 similar to adult individuals without infection) in peripheral blood, suggesting a lower activity potential of this cell type in newborns, which is in accordance with the literature. ${ }^{18-21}$

Regarding TLR-2, it was observed that it was widely expressed in neonatal monocytes (93.9\%) and monocytes of adult individuals without infection (94.6\%). The same similarity was observed regarding MFI for this receptor (MFI $=4,748$ and 6,386, respectively) regardless of culture positivity, contradicting findings in the literature that demonstrate an up-regulation in the expression of TLR-2 in monocytes isolated from patients with sepsis, as well as significant changes in TLR-2 expression. ${ }^{22,23}$ Thus, in the present study, in which all newborns had clinical and laboratory signs of infection, it was observed that despite presence of the necessary tools to recognize the invading antigen (TLR and co-stimulatory molecules), they did not undergo the up-regulation expected in the overall analysis.

Meanwhile, contrary to what was reported by Viemann et al. ${ }^{1}$ the presence of a positive culture was associated with a higher frequency in TLR-4 expression in relation to the adult individual with a negative culture, probably secondary to the fact that most patients with positive cultures had Gram-negative bacteria (60\%) isolated from the culture. As for the similar expression of the same receptor in newborns with negative cultures and in adult patients, it may suggest a tendency to immunoparalysis that would have shifted the median to lower levels, similar to the levels found in healthy adult individuals, as four newborns from this group progressed to septic shock.

The present study has limitations that should be emphasized, such as the sample size and the pointwise characteristic of the infectious picture assessment. However, the results still suggest that at the time of diagnostic hypothesis of infection in the newborns, TLR- 2 and TLR- 4 receptors had a higher expression in infants with infection, but with maintenance of expression of costimulatory molecules, indicating a possible deficiency in the cell activation process in vivo.

Thus, although larger extrapolations cannot be made, the authors believe it would be intriguing to assess the response of TLR as well as that of cell activation in newborns during the evolution of a clinical infection.

\section{Funding}

Fundação de Amparo à Pesquisa do Estado São Paulo FAPESP.

\section{Conflicts of interest}

The authors declare no conflicts of interest.

\section{Acknowledgements}

The authors would like to thank FAPESP for their financial support.

\section{References}

1. Viemann D, Dubbel G, Schleifenbaum S, Harms E, Sorg C, Roth J. Expression of toll-like receptors in neonatal sepsis. Pediatr Res. 2005;58:654-9. 
2. Dellinger RP, Levy MM, Carlet JM, Bion J, Parker MM, Jaeschke $\mathrm{R}$, et al. Surviving Sepsis Campaign: international guidelines for management of severe sepsis and septic shock: 2008. Crit Care Med. 2008;36:296-327.

3. Camacho-Gonzalez A, Spearman PW, Stoll BJ. Neonatal infectious diseases: evaluation of neonatal sepsis. Pediatr Clin North Am. 2013;60:367-89.

4. Bedford Russell AR. Neonatal sepsis. Paediatr Child Health. 2011;21:265-9.

5. Cianciarullo MA, Costa IC, Ceccon ME, Krebs VL. New and old markers on infection in neonatal sepsis diagnostic: critic vision. Pediatria (São Paulo). 2008;30:107-17.

6. Kollmann TR, Crabtree J, Rein-Weston A, Blimkie D, Thommai F, Wang XY, et al. Neonatal innate TLR-mediated responses are distinct from those of adults. J Immunol. 2009;183:7150-60.

7. Yoon HS. Neonatal innate immunity and toll-like receptor. Korean J Pediatr. 2010;53:985-8.

8. Muzio M, Bosisio D, Polentarutti N, D’amico G, Stoppacciaro A, Mancinelli R, et al. Differential expression and regulation of tolllike receptors (TLR) in human leukocytes: selective expression of TLR3 in dendritic cells. J Immunol. 2000;164:5998-6004.

9. Tipping PG. Toll-like receptors: the interface between innate and adaptive immunity. Am Soc Nephrol. 2006;17:1769-71.

10. Bochud PY, Calandra T. Pathogenesis of sepsis: new concepts and implications for future treatment. BMJ. 2003;326:262-6.

11. Higgins SC, Lavelle EC, McCann C, Keogh B, McNeela E, Byrne $\mathrm{P}$, et al. Toll-like receptor 4-mediated innate IL-10 activates antigen-specific regulatory $\mathrm{T}$ cells and confers resistance to Bordetella pertussis by inhibiting inflammatory pathology. J Immunol. 2003;171:3119-27.

12. Kadowaki N, Ho S, Antonenko S, Malefyt RW, Kastelein RA, Bazan $F$, et al. Subsets of human dendritic cell precursors express different toll-like receptors and respond to different microbial antigens. J Exp Med. 2001;194:863-9.

13. Nguyen M, Leuridan E, Zhang T, De Wit D, Willems F, Van Damme $\mathrm{P}$, et al. Acquisition of adult-like TLR4 and TLR9 responses during the first year of life. PLoS One. 2010;5:e10407.
14. PrabhuDas M, Adkins B, Gans H, King C, Levy O, Ramilo O, et al. Challenges in infant immunity: implications for responses to infection and vaccines. Nat Immunol. 2011;12:189-94.

15. Kollmann TR, Levy O, Montgomery RR, Goriely S. Innate immune function by Toll-like receptors: distinct responses in newborns and the elderly. Immunity. 2012;37:771-83.

16. Förster-Waldl E, Sadeghi K, Tamandl D, Gerhold B, Hallwirth U, Rohrmeister $\mathrm{K}$, et al. Monocyte toll-like receptor 4 expression and LPS-induced cytokine production increase during gestational aging. Pediatr Res. 2005;58:121-4.

17. Wynn JL, Levy O. Role of innate host defenses in susceptibility to early-onset neonatal sepsis. Clin Perinatol. 2010;37: 307-37.

18. Levy 0 . Innate immunity of the newborn: basic mechanisms and clinical correlates. Nat Rev Immunol. 2007;7: 379-90.

19. Dellinger RP, Levy MM, Rhodes A, Annane D, Gerlach H, Opal SM, et al. Surviving sepsis campaign: international guidelines for management of severe sepsis and septic shock: 2012. Crit Care Med. 2013;41:580-637.

20. Goldstein B, Giroir B, Randolph A. International Consensus Conference on Pediatric Sepsis. International pediatric sepsis consensus conference: definitions for sepsis and organ dysfunction in pediatrics. Pediatr Crit Care Med. 2005;6: 2-8.

21. Sánchez-Torres C, García-Romo GS, Cornejo-Cortés MA, RivasCarvalho A, Sánchez-Schmitz G. CD16+ and CD16- human blood monocyte subsets differentiate in vitro to dendritic cells with different abilities to stimulate CD4+ T cells. Int Immunol. 2001;13:1571-81.

22. Hirschfeld M, Ma Y, Weis JH, Vogel SN, Weis JJ. Cutting edge: repurification of lipopolysaccharide eliminates signaling through both human and murine toll-like receptor 2 . J Immunol. 2000;165:618-22.

23. Härter L, Mica L, Stocker R, Trentz O, Keel M. Increased expression of toll-like receptor-2 and -4 on leukocytes from patients with sepsis. Shock. 2004;22:403-9. 